Jurassic Paleobiogeography

of the Conterminous United States

in Its Continental Setting

GEOLOGICAL SURVEY PROFESSIONAL PAPER 1062 


\section{Jurassic Paleobiogeography}

of the Conterminous United States

\section{in Its Continental Setting}

By RALPH W. IMLAY

GEOLOGICAL SURVEY PROFESIONAL PAPER 1062

Paleogeographic changes in the United States during Jurassic time are revealed by the distribution, succession, and differentiation of molluscan faunas; by gross stratigraphic changes; by the position, extent, and duration of unconformities; and by comparisons with Jurassic data elsewhere in North America

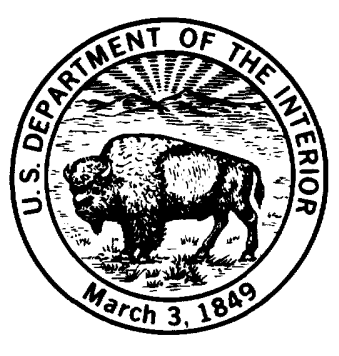




\section{UNITED STATES DEPARTMENT OF THE INTERIOR}

\section{CECIL D. ANDRUS, Secretary}

\section{GEOLOGICAL SURVEY}

H. William Menard, Director

Library of Congress Catalog-card No. 80-600017

For sale by the Superintendent of Documents, U.S. Government Printing Office Washington, D.C. 20402

Stock Number 024-001-03105-1 


\section{CONTENTS}

\begin{tabular}{|c|c|c|c|}
\hline & Page & & Page \\
\hline Abstract - & 1 & Comparisons of lithologic and stratigraphic features & 39 \\
\hline Introduction $\ldots$ & 3 & Gulf of Mexico and nearby regions-- & 39 \\
\hline Acknowledgments--- & 3 & Cuba - & 39 \\
\hline Paleobiogeographic setting------ & 4 & Gulf region of the United States & 46 \\
\hline Atlantic Coast-_-_- & 4 & Central and northeastern Mexico & 48 \\
\hline Gulf of Mexico and nearby regions-- & 4 & East-central Mexico & 49 \\
\hline Pacific Coast- & 17 & Southeastern Mexico--..-...- & 51 \\
\hline Western interior region --.- & 18 & Eastern Chihuahua and west Texas- & 51 \\
\hline Arctic region - ........ & 19 & Pacific Coast region - & 51 \\
\hline Succession of ammonites and buchias by stages --. & 19 & Western Mexico & 51 \\
\hline Hettangian-_- & 19 & Western Nevada to central California & 52 \\
\hline Sinemurian--..-- & 19 & Western California and southwestern Oregon--. & 61 \\
\hline Pliensbachian--.- & 19 & Eastern Oregon and western Idaho & 63 \\
\hline Toarcian------.-- & 21 & Northern Washington- & 66 \\
\hline - & 23 & British Columbia to southern Alaska-_- & 66 \\
\hline Bathonian-1- & 25 & Western interior region of the United States & 67 \\
\hline Callovian-1-_- & 29 & Montana and North Dakota & 67 \\
\hline Oxfordian & 30 & Southeastern Idaho to western South Dakota--_- & 82 \\
\hline Kimmeridgian -- & 30 & Northern Utah to northern Colorado & 91 \\
\hline Tithonian & 31 & North-central Utah to southwestern Colorado - - & 93 \\
\hline Definition and correlations & 31 & Southwestern Utah and northern Arizona-_- & 96 \\
\hline Lower Tithonian of the Gulf region- & 32 & Midcontinent region & 99 \\
\hline Upper Tithonian of the Gulf region--_._. & 34 & Jurassic unconformities & 99 \\
\hline Ammonite sequences & 34 & Jurassic geologic history --.. & 102 \\
\hline Kossmatia-Durangites ammonite assemblage -..-- & 34 & Atlantic Coast region & 102 \\
\hline Substeueroceras-Proniceras ammonite assem- & & Gulf of Mexico and nearby regions--.. & 103 \\
\hline blage - - & 35 & Pacific Coast region -... & 106 \\
\hline d Oregon - & 36 & Western interior region -....-. & 108 \\
\hline Tithonian of Canada and Alaska - & 36 & References cited--- & 114 \\
\hline tercontinental faunal relationships --..-- & 37 & Index - - & 127 \\
\hline
\end{tabular}

\section{ILLUSTRATIONS}

Figure 1. Jurassic basins of deposition in North America-

2-12. Maps showing distribution of Jurassic fossils and inferred seas in North America:

2. Hettangian-

3. Sinemurian-

4. Pliensbachian

5. Toarcian

6. Bajocian-

7. Bathonian -

8. Callovian-

9. Early to early middle Oxfordian-

10. Late middle Oxfordian to early Kimmeridgian

11. Late Kimmeridgian to early Tithonian -

12. Late Tithonian-

13. Succession and correlation of Hettangian to Toarcian ammonites in North America:

A. Mexico to southern British Columbia

B. Northern British Columbia to East Greenland 
FIgURE 14. Succession and correlation of Bajocian to Callovian ammonites in North America:

A. Mexico to western interior region-

B. British Columbia to East Greenland-

15. Succession and correlation of Oxfordian to Tithonian ammonites in North America:

A. Gulf of Mexico, Pacific Coast, and western interior region-

B. Southwestern Canada to Greenland

16. Comparisons of the Tithonian and Volgian Stages and the suggested subdivisions of the Tithonian

17. Index map of Jurassic areas in the Gulf of Mexico and nearby regions-

18. Index map of Jurassic areas in the Pacific Coast region from California and Nevada to Washington

19. Index map of Jurassic areas in the Pacific Coast region from British Columbia to southern Alaska

20. Index map of Jurassic areas in the western interior region-

21. Correlations and comparisons of Jurassic rocks in the Gulf of Mexico and nearby regions:

A. Western Cuba to Victoria, Mexico

B. Huasteca area, Mexico, to Malone Mountains, Tex -

22. Correlations and comparisons of Jurassic rocks in the Pacific Coast region in California, Nevada, and western to eastcentral Oregon:

A. Western Nevada and eastern California -

B. Western California to east-central Oregon

23. Correlations and comparisons of Jurassic rocks in the Pacific Coast region from eastern Oregon and western Idaho to northwestern Washington

24. Correlations and comparisons of Jurassic rocks in the Pacific Coast region in British Columbia, Yukon Territory, and southern Alaska:

A. Southwestern to central British Columbia

B. Northwestern British Columbia to southern Alaska-

25. Correlations and comparisons of Jurassic rocks in the western interior region from southwestern Alberta through central Montana to southern Saskatchewan:

A. Southwestern Alberta to central Montana-

B. Central Montana to southern Saskatchewan-

26. Correlations and comparisons of Jurassic rocks in the western interior region from southeastern Idaho to southwestern South Dakota:

A. Ammon area, Idaho, to Red Creek, Wyo-

B. Hyattville area in north-central Wyoming to Minnekahta area, South Dakota -

27. Correlations and comparisons of Jurassic rocks in the western interior region from north-central Utah to north-central Colorado:

A. Burr Fork to Whiterocks Canyon, Utah

B. Dinosaur Quarry, Utah, to Hahns Peak, Colo-

28. Correlations and comparisons of Jurassic rocks in the western interior region from north-central Utah to southwestern Colorado:

A. Monks Hollow to Black Dragon Canyon, Utah

B. San Rafael River, Utah, to McElmo Canyon, Colo-

29. Correlations and comparisons of Jurassic rocks in the western interior region from southwestern Utah to northeastern Arizona:

A. Gunlock to Brown Canyon, Utah

B. Little Bull Valley, Utah, to Cow Springs, Ariz

30. Jurassic unconformities in Gulf of Mexico and Pacific Coast regions

31. Jurassic unconformities in western interior region

32. Inferred extent of Jurassic seas of early Bajocian to earliest Callovian Age in western interior region--

33. Inferred extent of Jurassic seas of late early Callovian to early Kimmeridgian Age in western interior region

\section{TABLE}

TABLE 1. Thickness of the Piper and underlying Gypsum Spring Formations in parts of north-central Wyoming and southcentral Montana 


\section{CONVERSION FACTORS}

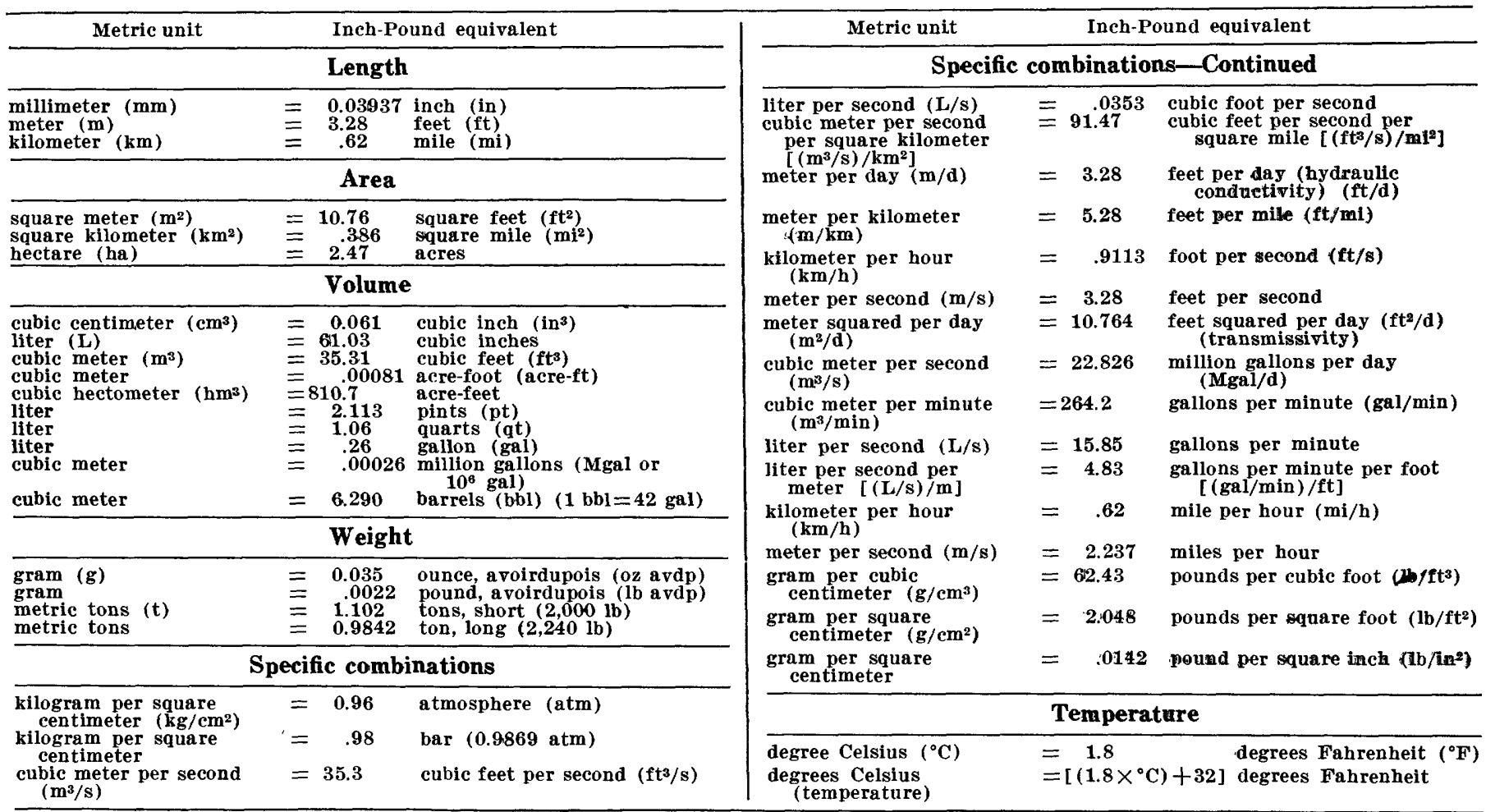





\title{
JURASSIC PALEOBIOGEOGRAPHY OF THE CONTERMINOUS UNITED STATES IN ITS CONTINENTAL SETTING
}

\author{
By RaLPh W. IMLAY
}

\begin{abstract}
During Jurassic time, marine sediments of considerable thickness including bedded salt were deposited on the outer part of the Atlantic Continental Shelf of the United States. The inner part of the shelf may have been inundated also during Oxfordian to Tithonian time, coincident with extensive flooding elsewhere in the Atlantic Ocean and in the Gulf of Mexico.

During the Early Jurassic, neither marine nor continental sediments seem to have been deposited within the area now covered by the Gulf of Mexico. Nonetheless, a marine embayment of Sinemurian to possibly early Pliensbachian Age did extend northward from the Pacific Ocean to east-central Mexico, where it terminated against a mass of metamorphic and granitic rocks in eastern Veracruz. The marine sediments deposited are carbonaceous, contain much plant material and some coal, and evidently were laid down in a warm humid climate. During the later Early Jurassic, they were strongly folded, faulted, intruded by igneous rocks, slightly metamorphosed, and then eroded. Presumably, erosion took place mostly in Toarcian time after tectonic movements in Pliensbachian time.

During the Middle Jurassic, marine sediments apparently were not deposited within the Gulf region until the late Bathonian. Continental sedimentation, however, took place in both Mexico and Cuba. In eastcentral Mexico, plant fossils show that continental deposition began in the early Bajocian. Such deposition took place over a larger area than that covered by the Lower Jurassic marine beds, continued until sometime in the Bathonian, but was followed by erosion before the early Callovian. In Cuba thousands of feet of carbonaceous plant-bearing beds were deposited during the Bajocian and Bathonian and possibly a little earlier. These plant-bearing beds show that the climate was warm and humid throughout the Gulf region during most of the Middle Jurassic.

During Callovian to early middle Oxfordian time, the Gulf region subsided and received some marine waters from the major oceans, which deposited thick masses of salt at various places. One marine embayment apparently extended westward into Cuba and was probably the major source of the salt. Another embayment extended from the Pacific Ocean into the Huasteca area of east-central Mexico, where it was separated from the Gulf at least in part by a land barrier located near the present Gulf coast. Salt was deposited mainly during late Callovian to early middle Oxfordian time, but deposition may have started in middle Callovian time. At about the same time in nearby areas in east-central and northeastern Mexico, varicolored continental beds and some red-weathering lava were deposited. The climate during deposition of the salt and nearby varicolored continental beds was probably hot and dry in the Gulf region. The red silt and sand were probably derived from upland areas to the west or north where the climate was hot and seasonally rainy.

Near the middle of the Oxfordian, major portals to the oceans were opened abruptly by major structural movements, and as a result seawater of normal salinity flowed quickly across the saline deposits and far beyond. Subsequently, during the later Jurassic, the Gulf of Mexico gradually deepened and widened; landmasses arose north of the Gulf
\end{abstract}

basin and shed considerable sediment southward; and deposition prevailed in open marine water from Cuba and Florida westward to central Mexico. Deposition continued into the Cretaceous in most parts of the Gulf region except in some northern nearshore areas. The climate in the Gulf region during Oxfordian to Tithonian time was probably hot and moderately humid. Rainfall apparently became greater after the early Kimmeridgian and was greater in eastern Mexico than in the southeastern United States, as shown by the presence of coal beds in Mexico. On the whole, the climate was probably similar to that in the western interior region during deposition of the Morrison Formation.

On the Pacific Coast during Jurassic time, marine deposition took place at depths ranging from very shallow to very deep, involved tremendous thickness of sediment, included much volcanic material, and gradually shifted westward.

During the Early Jurassic, a sea extended from the Pacific Coast as far east as the Snake River in easternmost Oregon and a similar distance east in Nevada. The deepest part of the sea probably trended northward through westernmost Nevada into eastern Oregon and beyond, as indicated by continuous deposition of fine-grained sediments from the Triassic into the Jurassic. By contrast, in eastern California, Jurassic sedimentation apparently did not begin before the Sinemurian.

During Bajocian time, a shallow sea covered nearly the same area as the Early Jurassic sea, except for an eastward extension into the western interior region. This sea received a great variety of sediments that included much volcanic material, except in Nevada. Deposition of beds of Bathonian Age in the Pacific Coast region of the conterminous United States has been demonstrated by fossils only in eastern Oregon. The absence of Bathonian fossils elsewhere could be explained by collecting failure; it could also reflect the beginning of intense volcanism which lasted into the early Oxfordian and which may at first have produced conditions on the sea bottom that were unfavorable for the preservation of fossils.

During the Callovian, marine waters covered most of the present area of California, Oregon, and Washington, and during earliest Callovian they also extended eastward into the western interior region. Enormous amounts of coarse to fine volcanic debris were ejected from volcanoes and fissures into the sea, where they became mixed with sediments derived from islands and larger landmasses. Apparently deposition continued throughout the epoch, except in eastern Oregon. The formation of oceanic crust during the Bathonian or Callovian epochs, or both, is suggested by the characteristics of the Rogue Formation in western Oregon.

Marine sedimentation persisted in the Pacific Coast region without any apparent interruption, from Callovian to early Kimmeridgian time, over a large area including California, western Oregon, and probably northwestern Washington. During the early Oxfordian, deposition of highly volcanic sediments continued just as during the Callovian. By contrast, from late Oxfordian to early Kimmeridgian, the most common sediments deposited were dark clay and silt, which in most places included only fine volcanic material.

At the end of the early Kimmeridgian, marine deposition ceased in areas underlain by the Mariposa Formation in eastern California, and by the Galice Formation in western Oregon and in nearby California. 
Those areas were then uplifted, and the rocks were folded, intruded locally by igneous rocks, and strongly eroded before the end of the Jurassic.

In some other places near the present Pacific Coast, marine sediments were deposited from the late Kimmeridgian to the Tithonian, but in many other places such deposition apparently only took place during the Tithonian. Some of the sediments, now represented by the Knoxville and Riddle Formations, consist mostly of nonvolcanic terrigenous clastic materials which locally contain limestone lenses and which were deposited in shallow waters. Other sediments, represented by the Dothan and Otter Point Formations and by the Franciscan assemblage, consist of volcanic clastic materials, breceia, lava, and chert and were deposited in deep waters. All available evidence indicates that the volcanic sediments were deposited far west of the nonvolcanic sediments and in much deeper waters, but that deposition of both began at about the same time on oceanic crust of late Oxfordian to early Kimmeridgian Age. Evidently, the oceanic crust was formed at the same time at which the Galice and Mariposa Formations were being deposited in areas far to the east.

That the climate in California and Oregon during Jurassic time was probably warm is indicated by the presence of ammonites of Mediterranean (Tethyan) affinities in those States and by the lack of certain ammonites that are common in the Arctic region and along the Pacific Coast as far south as British Columbia. The change is similar to that found in Jurassic ammonite faunules between northwest Europe and the Mediterranean region.

During the Early Jurassic, the western interior region south of Montana received as much as 3,000 feet $(915 \mathrm{~m})$ of continental sediments deposited under fluviatile and eolian environments. During the late Oxfordian, Kimmeridgian, and probably early Tithonian, the region received hundreds of feet of continental sediments deposited under fluviatile, lacustrine, and swampy environments. Between these two episodes, the area was invaded five times by marine waters that entered from the west through Idaho, Washington, or Alberta. Three of the invasions were followed by complete withdrawals of the sea from the region and two by partial withdrawals.

The sea first invaded southeast Idaho early in the Bajocian, extended from there northeast into the Williston basin and southward into southwest Utah, and then withdrew completely at about the beginning of the middle Bajocian. That sea left deposits of gypsum, red silt, limy mud, some chert, and locally in the Williston basin, a little salt. The characteristics of these sediments show that the sea was very shallow, that its initial sediments were laid down in highly saline waters, that later sediments were deposited in slightly deeper waters which supported some marine organisms, and that the sea deepened a little in southeastern Idaho.

The second and greatest marine invasion of the western interior region started in the late middle Bajoeian and lasted until the early Callovian. The sea underwent marked shallowing in the middle Bathonian and then withdrew nearly completely in late early to middle Callovian. It entered across northern Utah, eastern Idaho, and southern Alberta, surrounded a large island in central Montana, and was much more extensive than the sea of the earlier Bajocian except in eastern and southern Wyoming during late Bajocian to early Bathonian. From late Bathonian to early Callovian, however, it advanced across Wyoming into South Dakota beyond the erosional eastern limit of beds of early Bajocian Age. In this sea were deposited clayey to dense to oolitic lime mud, limy clay and silt, gray to yellow limy sand, and some red silt and gypsum. The sediments deposited at any one time were similar over great distances, except for the initial deposits that filled irregularities on the underlying erosion surface. Most of the sediments were deposited as the sea transgressed. Regressive deposits include the Boundary Ridge and Giraffe Creek Members of the Twin Creek Limestone and their equivalents.
The second marine invasion was terminated near the middle of the Callovian by the rise and enlargement of a large island in Montana that cut off marine waters from the north. South of this island in very shallow, probably highly saline waters were deposited unfossiliferous, red, even-bedded, fine-grained sand that thickens westward from 100 to 1,000 feet ( 30 to $300 \mathrm{~m}$ ) or more, and that extends from the Black Hills area southwestward through southern Wyoming and northernmost Utah into southeastern Idaho. Near Idaho Falls, the lower part of the sand was deposited along with some marine lime mud and sand. This marine facies thins eastward to an area near the western boundary of Wyoming where bedded salt and gypsum were deposited at about the same stratigraphic position over a distance of several hundred miles (several hundred kilometers) from north to south. Evidently, marine and lagoonal conditions persisted to the west in Idaho at the same time that ned sand was being deposited farther east in highly, saline or possibly brackish waters and at the same time that light-colored, crossbedded sand was being reworked by winds in the Colorado Plateau.

The third marine invasion into the western interior region apparently happened during the late middle to early late Callovian, in some places immediately after deposition of red even-bedded sand and equivalent eolian sand and in other places after a brief interval of erosion. The sea extended eastward across northern Utah, southern Idaho, northern Coloradb, and southern Wyoming into South Dakota. It may have also extended northward from the Black Hills area into southern Saskatchewan, where it could be represented by all or part of the glauconitic deposits called the Roseray Formation (equals middle member of the Vanguard Formation).

In this sea, highly glauconitic limy sand, sandy silt, some gypsum, and some limy mud (Curtis Formation and Pine Butte Member of the Sundance Formation) were deposited in very shallow water, as shown by the presence of Ostrea, Lopha, Lingula, and Meleagrinella. Such sediments in the San Rafael.swell were overlain conformably by, and passed laterally southeastward into, unfossiliferous chocolate-brown, red, or gray even-bedded sand; silt, and clay, and, locally, some gypsum. Such sediments were probably deposited in highly saline water in marginal areas of the sea. Deposition of both the marine, brackish-, and saline-water sediments was followed rather quickly by withdrawal of the sea completely from the western interior region and by an interval of erosion that lasted until early Oxfordian time.

The fourth marine invasion into the western interior region entered central Montana east of the Sweetgrass arch during the latest Callovian and possibly entered the Williston basin even earlier. During the early Oxfordian, the sea spread widely, but did not advance as far south in Utah as the preceding sea, and apparently did not spread west of the Sweetgrass arch. At the end of the early middle Oxfordian, the sea withdrew northward into northern Wyoming and the Williston basin but spread westward in Montana at least as far as the Sawtooth Range south of Glacier Park. It persisted in Montana at least to the end of the Oxfordian. The sea was bounded on the west in central Ldaho and possibly in westernmost Montana by a landmass that shed considerable clastic sediment eastward. This is shown by a change from mostly glauconitic, calcareous sand, sandy lime, and sandy silt in the west to mostly silt and clay farther east. The sea was shallow, as shown by the presence of Ostrea, Mytilus, and Meleagrinella, and by abundant ripple marks and crossbedding. The climate was probably warm and humid, as shown by the presence of many wood fragments in the Swift Formation in western Montana.

The northward withdrawal of the sea in Montana during the early middle Oxfordian was followed by a brief fifth marine invasion southward from Montana and northern Wyoming as far as northwestern Colorado and northeastern Utah. In this sea was deposited a thin unit (Windy Hill Sandstone Member of the Sundance Formation) of yellowish-gray, limy, locally oolitic, ripple-marked sand, and a little gray to green mud that contains a few mollusks, such as Ostrea. These marine 
sediments were deposited unconformably on the Redwater Shale Member of the Sundance Formation and conformably below the continental Morrison Formation. As they are not recognizable as a lithologic unit north of the Wind River Basin in central Wyoming, they presumably pass northward into the upper part of the Redwater Shale Member in northern Wyoming.

During later Jurassic time, continental sediments (Morrison Formation) were deposited on flood plains and in lakes throughout much of the western interior region and in coal-forming swamps in Montana. Continental deposition began during the early or late Oxfordian in the southern part of the region, definitely during the late Oxfordian in the central part, and probably as late as the Kimmeridgian in northern Montana. It persisted in all parts at least through the Kimmeridgian. Sediments in the southern and central parts of the western interior region were derived from the south and west. In the northern part, they were derived from the east and west. Evidently, continental sedimentation began at about the same time as deposition of the marine Norphlet and Smackover Formations of the Gulf region. Uplift of land areas from which the continental sediments were derived apparently occurred at the same time as uplift of the land areas that shed sediment southward into the Gulf of Mexico during late Oxfordian to Tithonian time.

The Jurassic ammonite succession in North America from Hettangian through early Bajocian time is essentially the same as elsewhere in the world. Ammonite assemblages of late Pliensbachian Age are differentiated from north to south, just as they are in Europe. Ammonite assemblages of middle Bajocian Age in the Pacific Coast region contain some genera that are known only from areas bordering the Pacific Ocean, but overall their generic resemblances to European ammonites are striking.

In contrast, from late Bajocian time until the end of the Jurassic, marked differentiation of ammonite faunas took place from north to south. The ammonite successions in the Gulf region and in the Pacific Coast region as far north as southern California remained closely similar to those in the Mediterranean region. The succession from northern California to northern Alaska became similar to that in northern Eurasia, although some mingling of genera of Boreal and Mediterranean affinities occurred in California and Oregon. Such mingling and the presence of genera known only from the Western Hemisphere or from areas bordering the Pacific Ocean have aided greatly in making fairly accurate correlations of rocks in widely separated areas.

The differentiation of ammonite faunas from north to south can be reasonably ascribed to partial isolation of an arctic sea from the Pacific Ocean, except for at least one connection through Yukon Territory during Middle and most of Late Jurassic time, and another connection from East Greenland to northwest Europe from the beginning of Callovian time.

\section{INTRODUCTION}

This report is a successor to that written by Imlay and Detterman (1973) on the Jurassic Paleobiogeography of Alaska. It is more detailed because much more information is available concerning the conterminous United States. It deals in a broad way with changes in Jurassic geography, stratigraphy, and ammonite assemblages. It presents paleogeographic maps depicting the main areas of Jurassic marine deposition and most of the marine Jurassic megafossil occurrences in North America (figs. 1-12). It presents charts depicting the succession of ammonite taxa and Buchia species in North
America (figs. 13-16), the locations of some of the best known Jurassic sequences (figs. 17-20), the gross stratigraphic and lithologic changes in space and time (figs. 21-29), and the position, extent, and duration of unconformities during Jurassic time (figs. 30, 31). In addition, the report discusses most existing published stratigraphic, lithologic, and faunule knowledge in sufficient detail to substantiate the interpretations presented on the maps, on the charts, and in the section on Jurassic geologic history.

Most of the geographic features, areas, and towns mentioned in this report are shown on figures 17-20. Further locality data concerning such features in the Gulf of Mexico region are shown in papers by Imlay (1943a, p. 1408, 1409, 1412, 1496, 1503, 1509; 1952a, p. 954; 1953c, figs. 2-4), Swain (1944, p. 583), K. A. Dickinson $(1968$, p. E2), and Lopez Ramos (1974, p. 382, $385,388,391)$. Such data for the Pacific Coast region of the United States and Canada are shown in papers by Imlay (1952a, p. 956; 1961, p. D15; 1973, pl. 48; Imlay and Jones, 1970, p. B19); Frebold and Tipper (1970), and Imlay and Detterman (1973, p. 7). Such data for the western interior region are shown in papers by Baker, Dane, and Reeside (1936), Imlay (1952a, p. 956; 1953a, p. 12; 1956a, p. 563; 1957, p. 472; 1962b, p. C8, C9; 1967b, p. 5, 63-65), Frebold (1957, figs. 1, 2; 1969, fig. 1), Brooke and Braun (1972, fig. 1), J. A. Peterson (1957, p. 402, 403), and Pipiringos and O'Sullivan (1975).

\section{ACKNOWLEDGMENTS}

For the data published herein, the writer is indebted to many geologists from Canada, the United States, and Mexico. Canadians who contributed include Hans Frebold, J. A. Jeletzky, and H. W. Tipper of the Canadian Geological Survey; M. M. Brooke, W. K. Brown, J. E. Christopher, and D. F. Paterson of the Saskatchewan Geological Survey; and L. W. Vigrass of the University of Saskatchewan. In the United States, information was provided by George Gryc, K. A. Dickinson, Arthur Grantz, D. L. Jones, J. D. Love, W. J. Mapel, A. A. Baker, W. A. Cobban, E. M. MacKevett, Fred Peterson, G. N. Pipiringos, Donald Richter, E. H. Bailey, W. P. Irwin, L. D. Clark, R. L. Detterman, and Robert Sharp of the U.S. Geological Survey; George Herman and Jules Braunstein of Shell Oil Co.; W. E. Humphrey of American International Oil Co. (Amoco); R. T. Hazzard of Gulf Oil Co.; W. B. Weeks of Phillips Oil Co.; F. M. Swain of the University of Minnesota; W. R. Dickinson of Stanford University; J. A. Peterson of the University of Montana; and many others. In Mexico, those providing data included Gloria Alencaster de Cserna, Manuel Alvarez, Jr., Abelardo Cantú Chapa, Edmundo Cepeda, D. A. 
Cordoba, Zoltan de Cserna, Teodoro Díaz-Gonzalez, E. J. Guzmán Jiménez, Ernesto Lopez Ramos, Roberto Flores Lopéz, G. P. Salas, Hector Ochoterana F., Francisco Viniegra O., and J. P. Alor, all of whom are affiliated with either Petroleos Mexicanos or the Instituto Geologico de Mexico.

Special thanks are due George Pipiringos and Fred Peterson of the U.S. Geological Survey for sharing information and exchanging interpretations concerning the stratigraphic relationships of Jurassic formations in the western interior region.

The writer is much indebted to John $\mathrm{H}$. Callomon of University College, London, England, and to Tove Birkelund of the University of Copenhagen, Denmark, for ammonite biostratigraphic data concerning the position of the Bathonian-Callovian boundary in East Greenland and its probable position in Alaska and Montana.

\section{PALEOBIOGEOGRAPHIC SETTING}

\section{ATLANTIC COAST}

Jurassic marine beds have not been identified definitely along the Atlantic Coast of the United States, although 45 feet $(13.7 \mathrm{~m})$ of limy beds of possible Late Jurassic age have been penetrated in two wells at Cape Hatteras, N.C. Three species of ostracodes have been found, of which two, belonging to the genus Schuleridea, have been found elsewhere in the Schuler Formation (Upper Jurassic) of the southeastern United States; one belongs to the genus Octocythere, which is known only from the Jurassic (Swain, 1952, p. 59, 60; Swain and Brown, 1972, p. 8, 9; Brown and others, 1972, p. 38). These possible Jurassic beds are about 370 miles $(600$ $\mathrm{km}$ ) west of the marine Upper Jurassic sequence about 560 feet $(170 \mathrm{~m})$ thick that was cored at JOIDES Site 105 in the Hatteras Abyssal Plain (Hollister and others, 1972). It is about 60 miles $(100 \mathrm{~km})$ west of the western margin of Jurassic beds suggested by Emery and Uchupi (1972, p. 95).

No drilling reports have yet been published that prove the presence of Jurassic beds along the Atlantic Continental Shelf of the United States. Nonetheless, seismic data suggest the presence of thousands of feet of both Jurassic and Lower Cretaceous beds along the entire shelf area from Maine to Florida (Ballard and Uchupi, 1974 , p. 1158; Schultz and Grover, 1974, p. 1164, 1165; Minard and others, 1974, p. 1172, 1176; Olson, 1974, p. $1196,1197)$. Furthermore, salt concentrations in pre-Upper Cretaceous rocks in coastal areas between Delaware and Florida suggest that evaporitic facies of possible Jurassic age may be present seaward from the present coastline (Mattic and others, 1974, p. 1182, 1183). Marine Jurassic sedimentation along the Atlantic Coast was probably influenced in places by the Palisade disturbance, which is now definitely dated as Jurassic, rather than Triassic, by the presence of palynofloras of Early Jurassic age from the top of the Newark Group (Cornet and others, 1973; Cornet and Traverse, 1975, p. 25-27). This evidence is supported by some K-Ar dates for the Palisades sill that intrudes the Newark Group in New Jersey (Dallmeyer, 1975) and by K-Ar dates for lava flows in the middle of the Newark Group in the Hartford basin of Connecticut and the Deerfield basin of Massachusetts (Armstrong and Besancon, 1970).

Jurassic beds of considerable thickness have been identified by means of microfossils found in deep wells drilled along the Atlantic Coast of eastern Canada (Sherwin, 1973, p. 529, 534-537; Upshaw and others, 1974, p. 1132). For the Nova Scotia shelf, the fossil evidence shows that the marine Lower and Middle Jurassic beds are about 6,600 feet $(2,012 \mathrm{~m})$ thick, and those for the Upper Jurassic are at least 8,200 feet $(2,500 \mathrm{~m})$ thick (McIver, 1972, p. 56-62). The sequence includes a basal salt unit about 2,500 feet $(760 \mathrm{~m})$ thick that is dated as probably earliest Jurassic on the basis of its microflora and its stratigraphic continuity with overlying marine beds that are dated as Early Jurassic (Pliensbachian). The Jurassic sequence may also include several hundred feet of red beds that are gradational upward into the main salt mass and that rest on metamorphosed sedimentary rock.

In the Grand Banks of Newfoundland, microfossils of Early to Late Jurassic age have been reported throughout at least 20,000 feet $(6,100 \mathrm{~m})$ of beds penetrated by drilling (Upshaw and others, 1974, p. 1132). These beds consist of clastic oolitic to dense limestone, gray to red siltstone and mudstone, and limy fine-grained sandstone. In the Murre well, the Lower Jurassic is represented by 1,120 feet $(341 \mathrm{~m})$ of limestone whose basal 600 feet ( 183 $\mathrm{m}$ ) contains bedded anhydrite and some salt. In addition, some salt, penetrated in two salt domes, has been interpreted as of Early Jurassic age or older (Bartlett and Smith, 1971, p. 67-69; Amoco, 1974, p. 1112-1115; Upshaw and others, 1974, p. 1127-1129).

Studies of Foraminifera, ostracodes, dinoflagellates, spores, and pollen, obtained from well cutting on the Scotian Shelf and the Grand Banks, show that the oldest dated beds are of Bathonian to Callovian Age (Ascoli, 1974, p. 132, 133; Williams, 1974). The underlying saltbearing beds are referred to the Early Jurassic, however, although the evidence for such dating is not yet published (Jansa, 1974, p. 141).

\section{GULF OF MEXICO AND NEARBY REGIONS}

Thick Jurassic deposits are widespread in Mexico, the southern United States, and Cuba. Marine beds of 


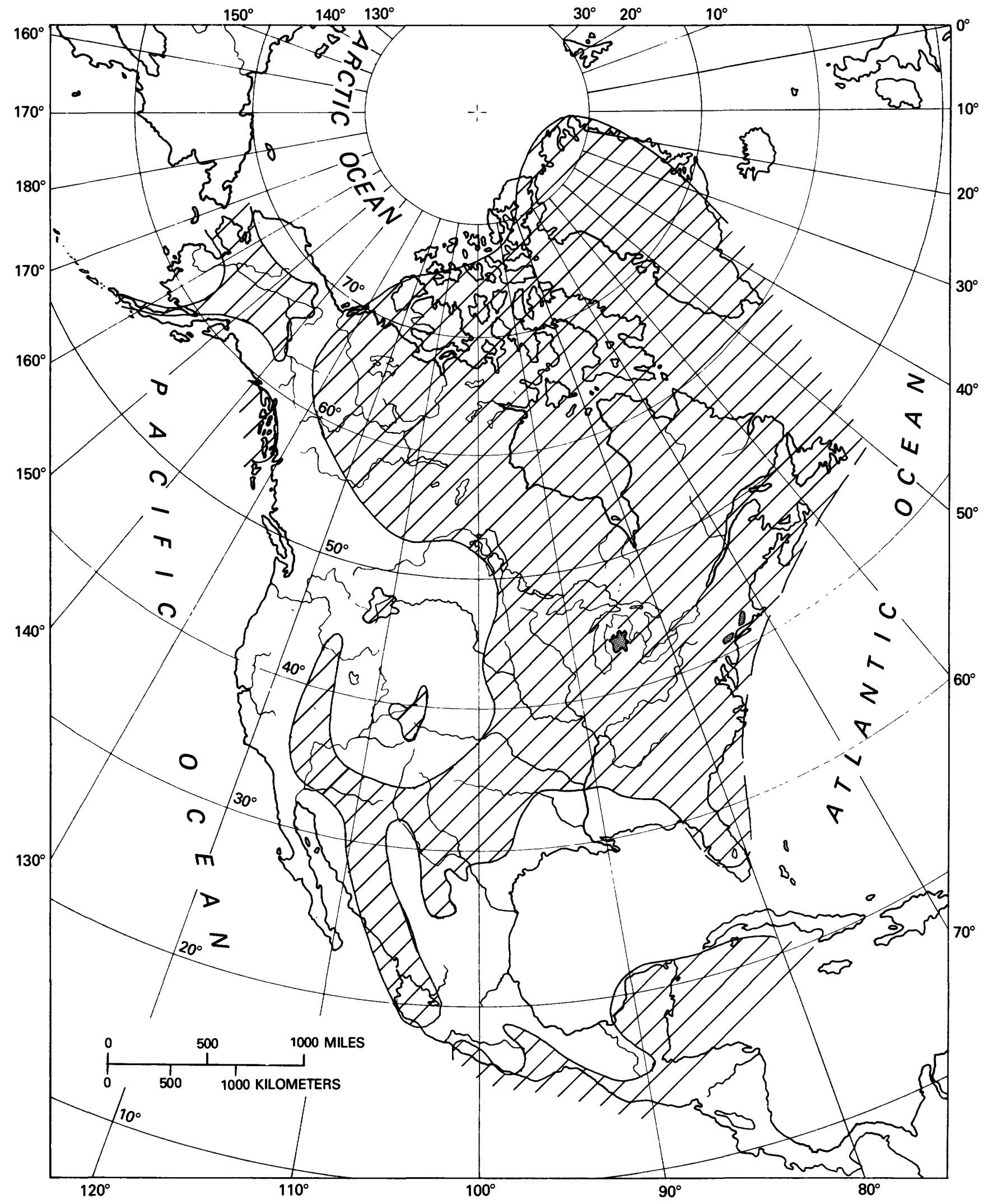

FIGURE 1.-Jurassic basins of deposition in North America. Note small basins of continental deposition in central Michigan, northern New Jersey, and Connecticut to southern Massachusetts. Land areas are ruled. 


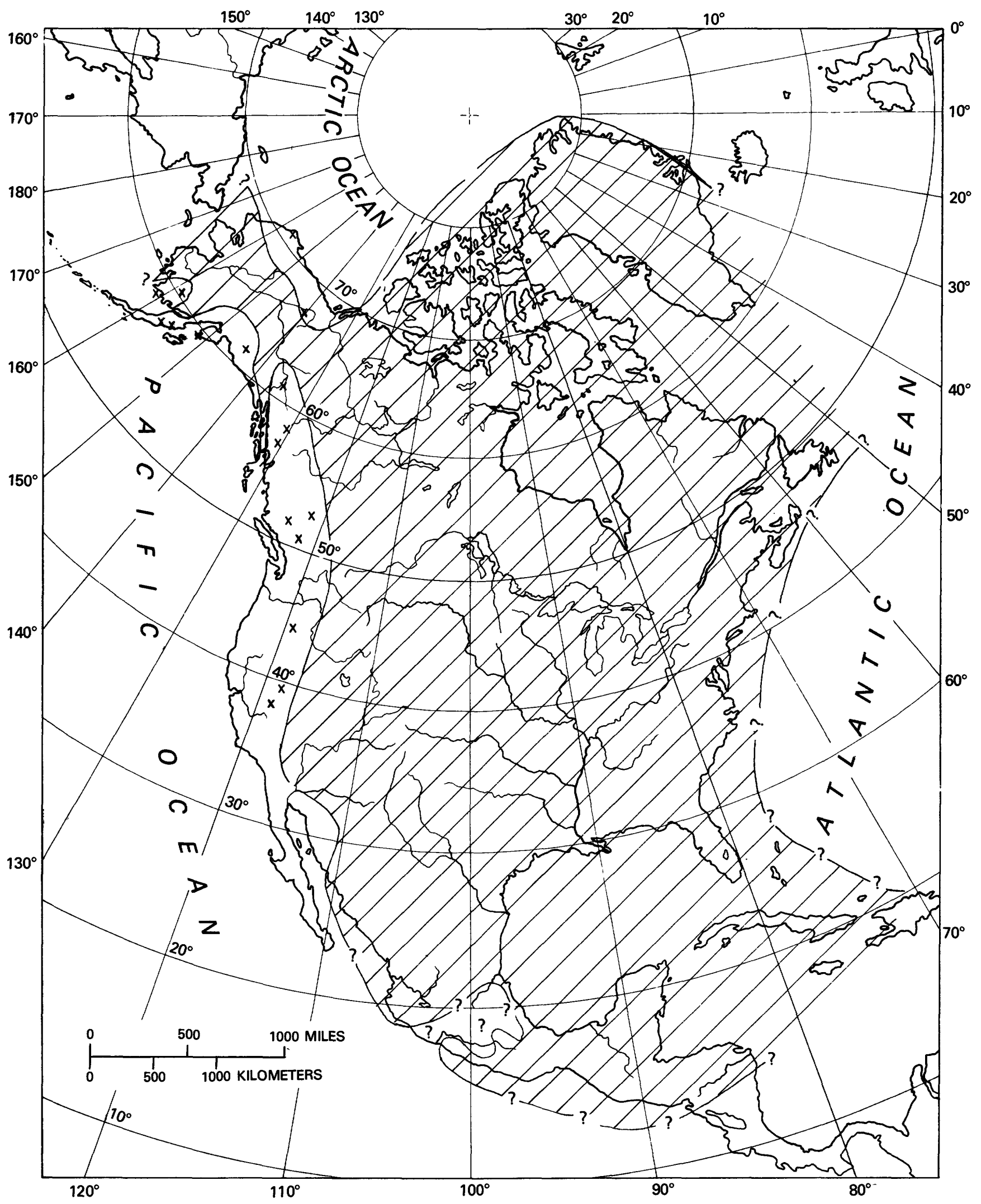

Figure 2.-Distribution of Hettangian fossils (X) and inferred seas in North America. Land areas are ruled. 


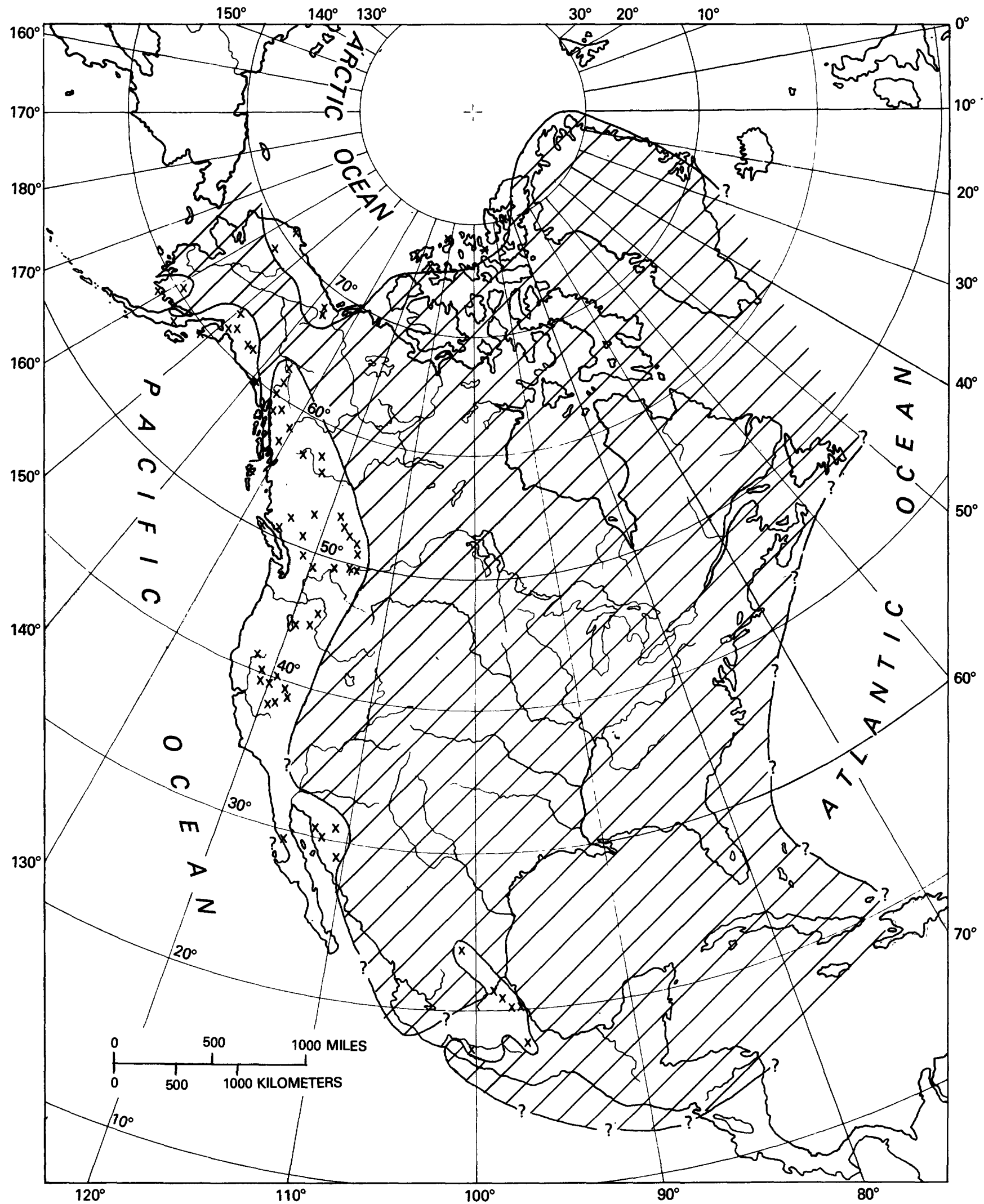

FIgURE 3.-Distribution of Sinemurian ammonites $(\mathrm{X})$ and inferred seas in North America. Land areas are ruled. 


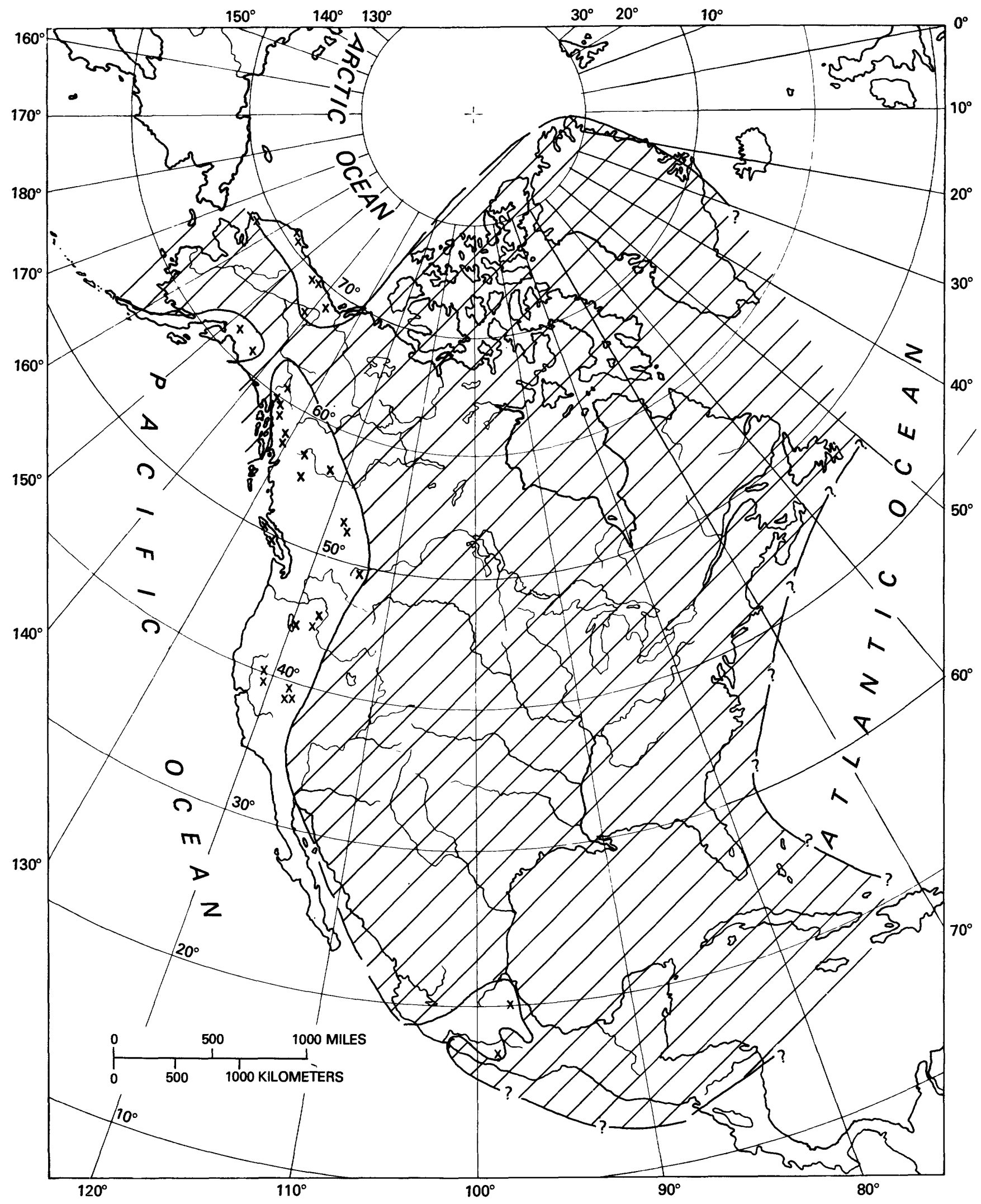

FIgURE 4.-Distribution of Pliensbachian fossils (X) and inferred seas in North America. Land areas are ruled. 


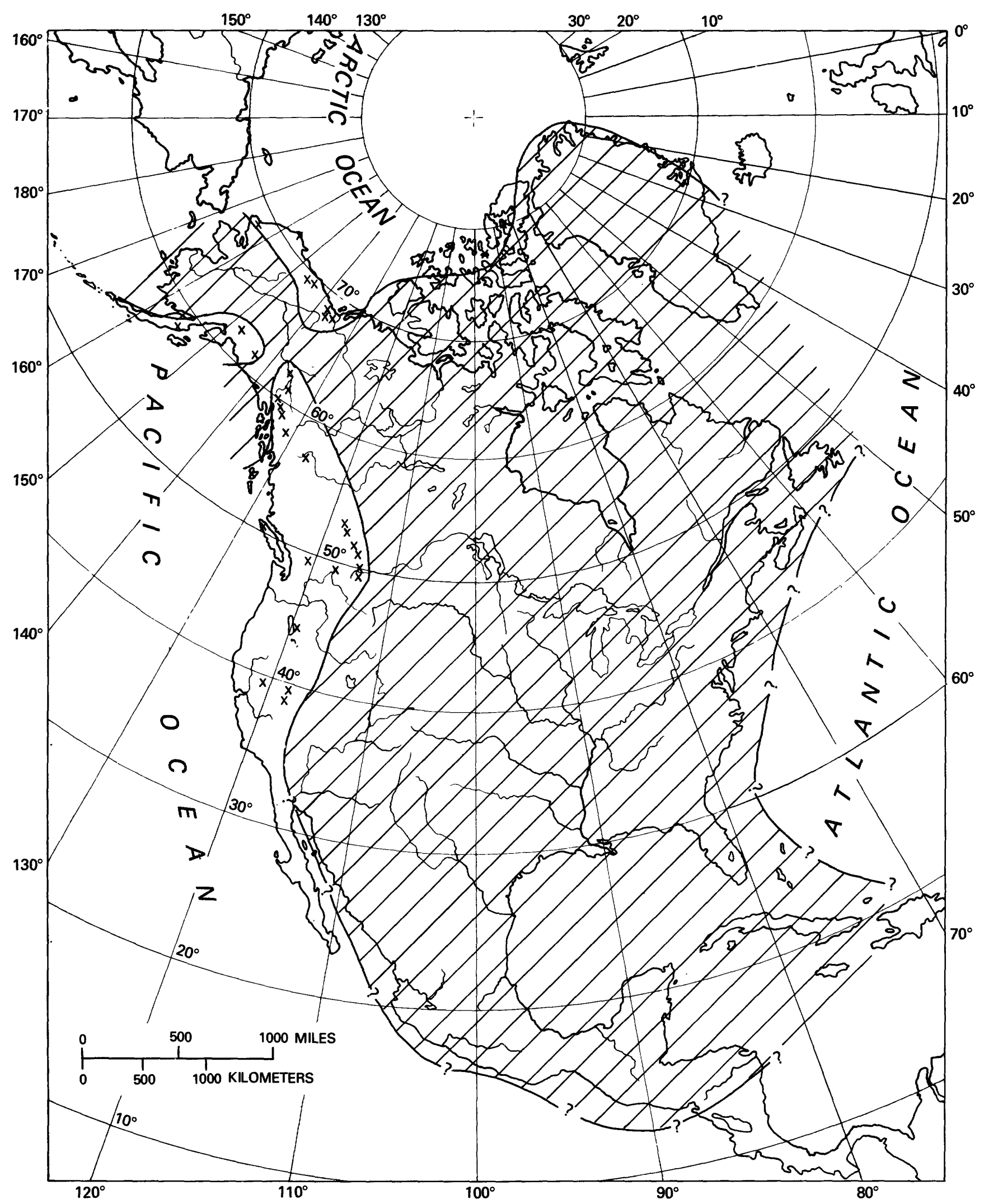

FIGURE 5.-Distribution of Toarcian fossils (X) and inferred seas in North America. Land areas are ruled. 


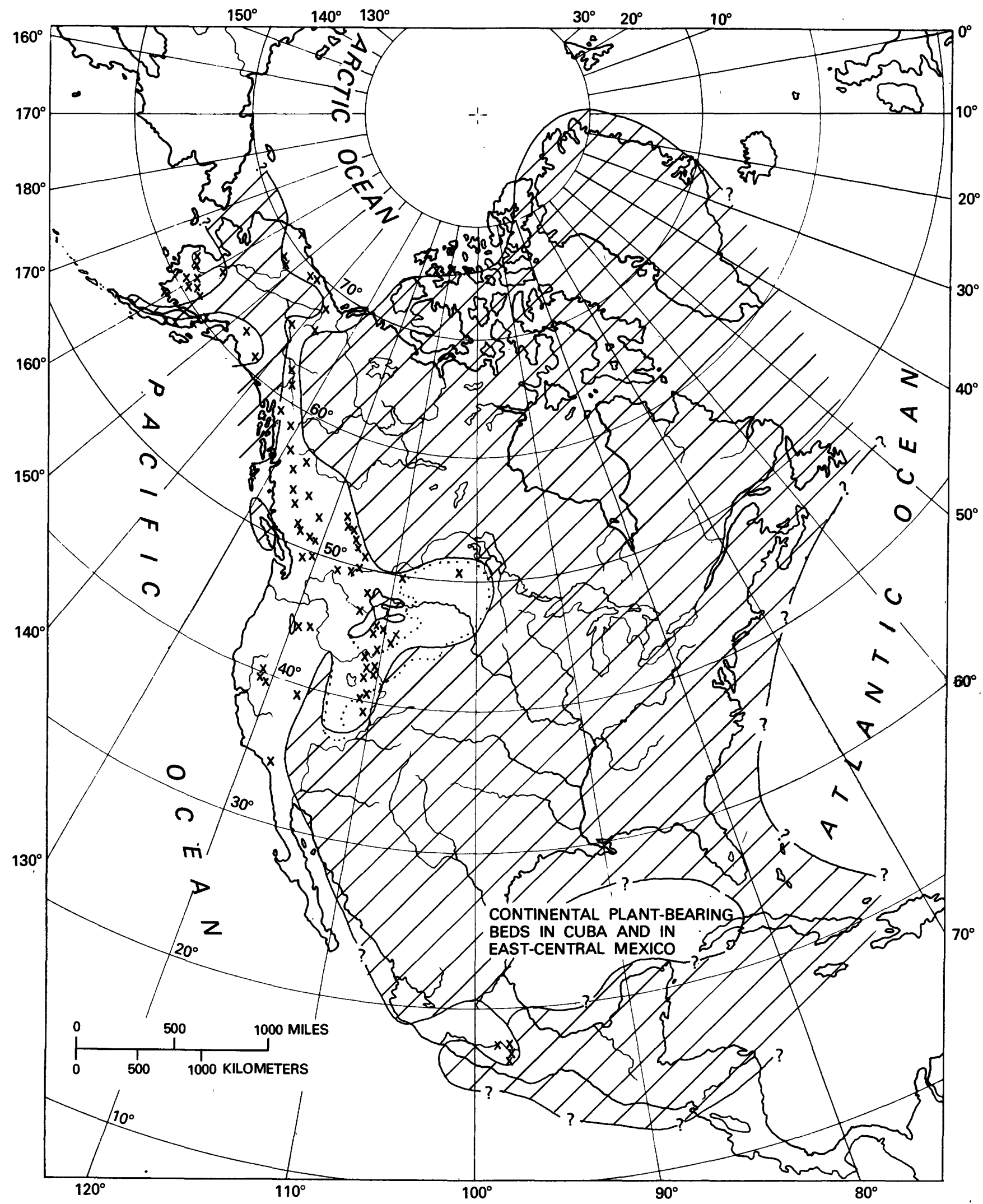

FIGURE 6.-Distribution of Bajocian fossils (X) and inferred seas in North America. Land areas are ruled. Extent of early Bajocian sea in western interior region is indicated by dotted line. Extent of late middle to late Bajocian sea in western interior region is indicated by
solid line. 


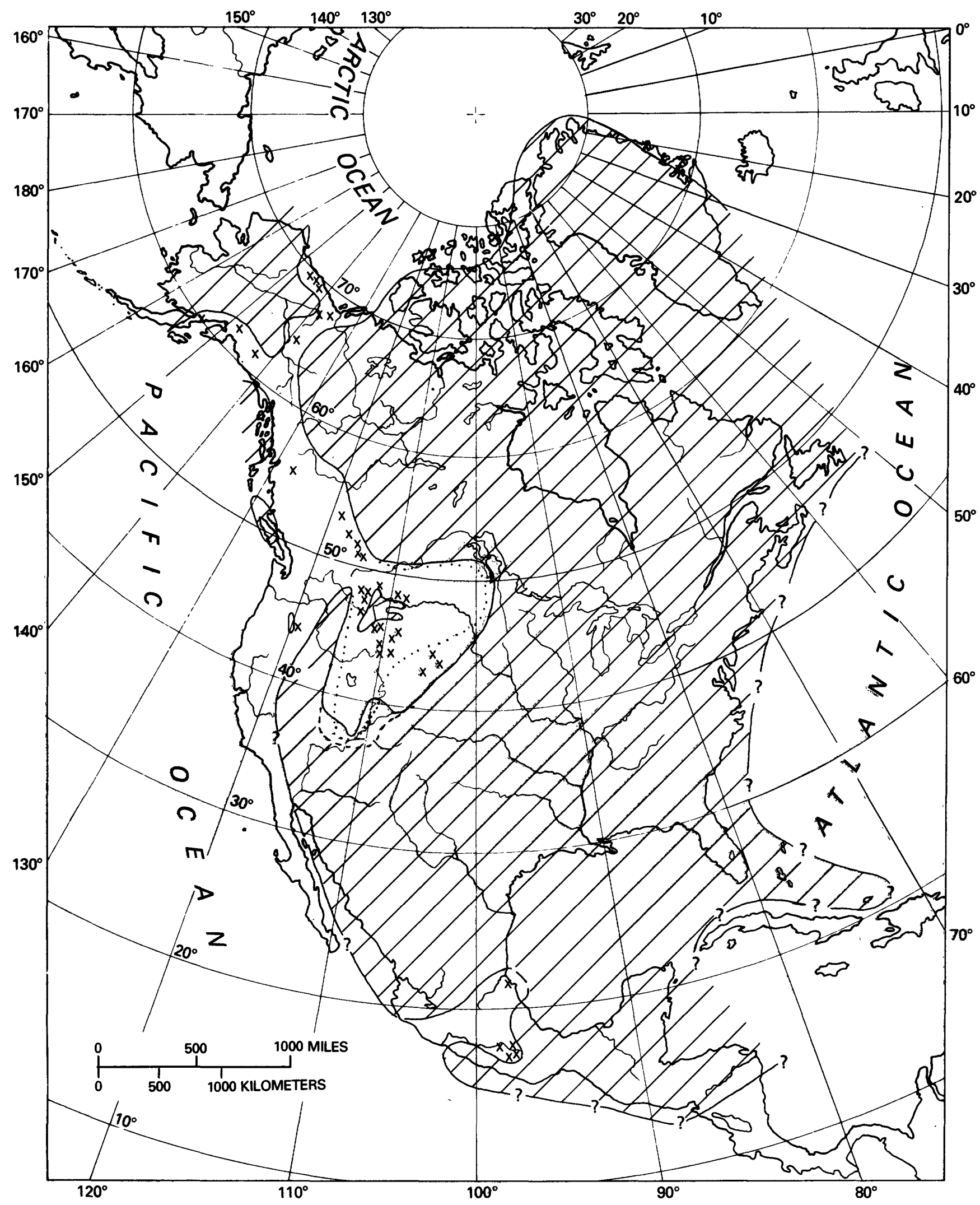

H'IGURE 7.-Distribution of Bathonian fossils (X) and inferred seas in North America. Land areas are ruled. Extent of early Bathonian sed in western interior region is indicated by dotted line. Extent of late Bathonian sea in western interior region is indicated by solid line. Extent of late Bathonian tidal flat and continental deposits is indicated by dashed line. 


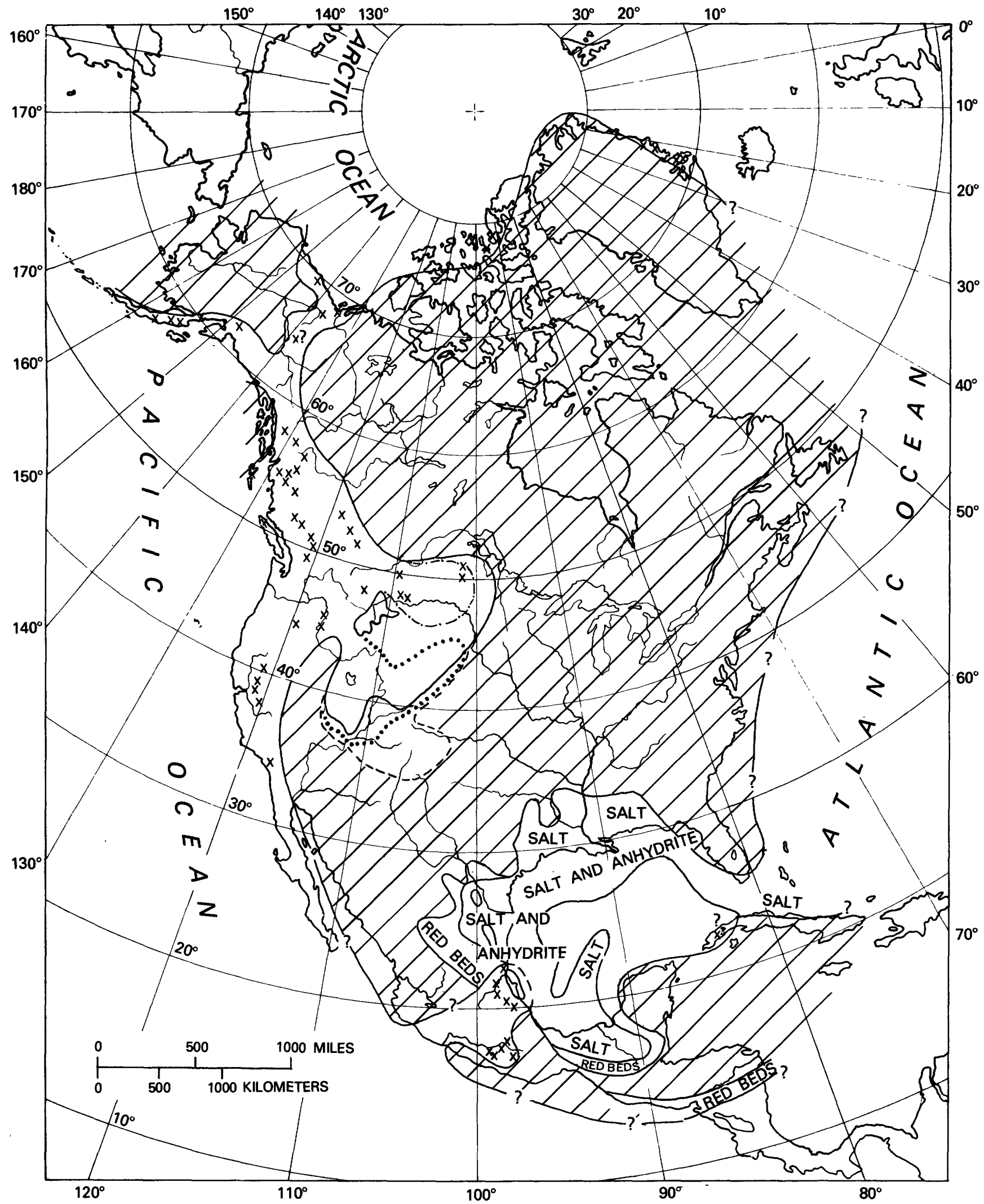

Figure 8. -Distribution of Callovian fossils (X) and inferred seas in North America. Land areas are ruled. Extent of earliest Callovian sea in western interior region is indicated by solid line. Extent of late middle Callovian sea (Curtis and Summerville time) is indicated by dotted line. Extent of Callovian continental beds is indicated by dashed line. Possible extent of latest Callovian sea is indicated by alternating dots and dashes. 
PALEOBIOGEOGRAPHIC SETTING

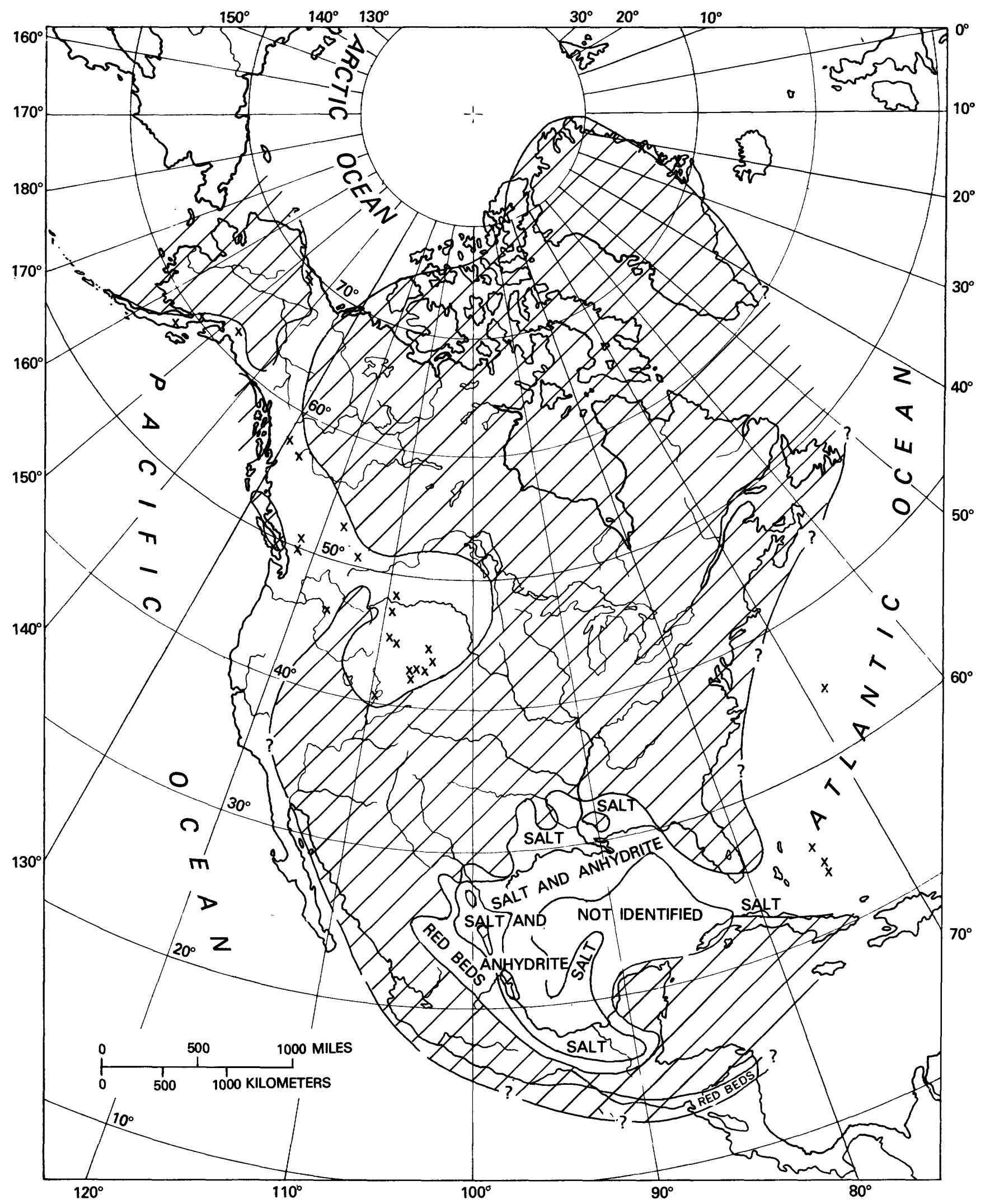

FlGURE 9.-Distribution of early to early middle Oxfordian fossils (X) and inferred seas in North America. Land are areas ruled. 


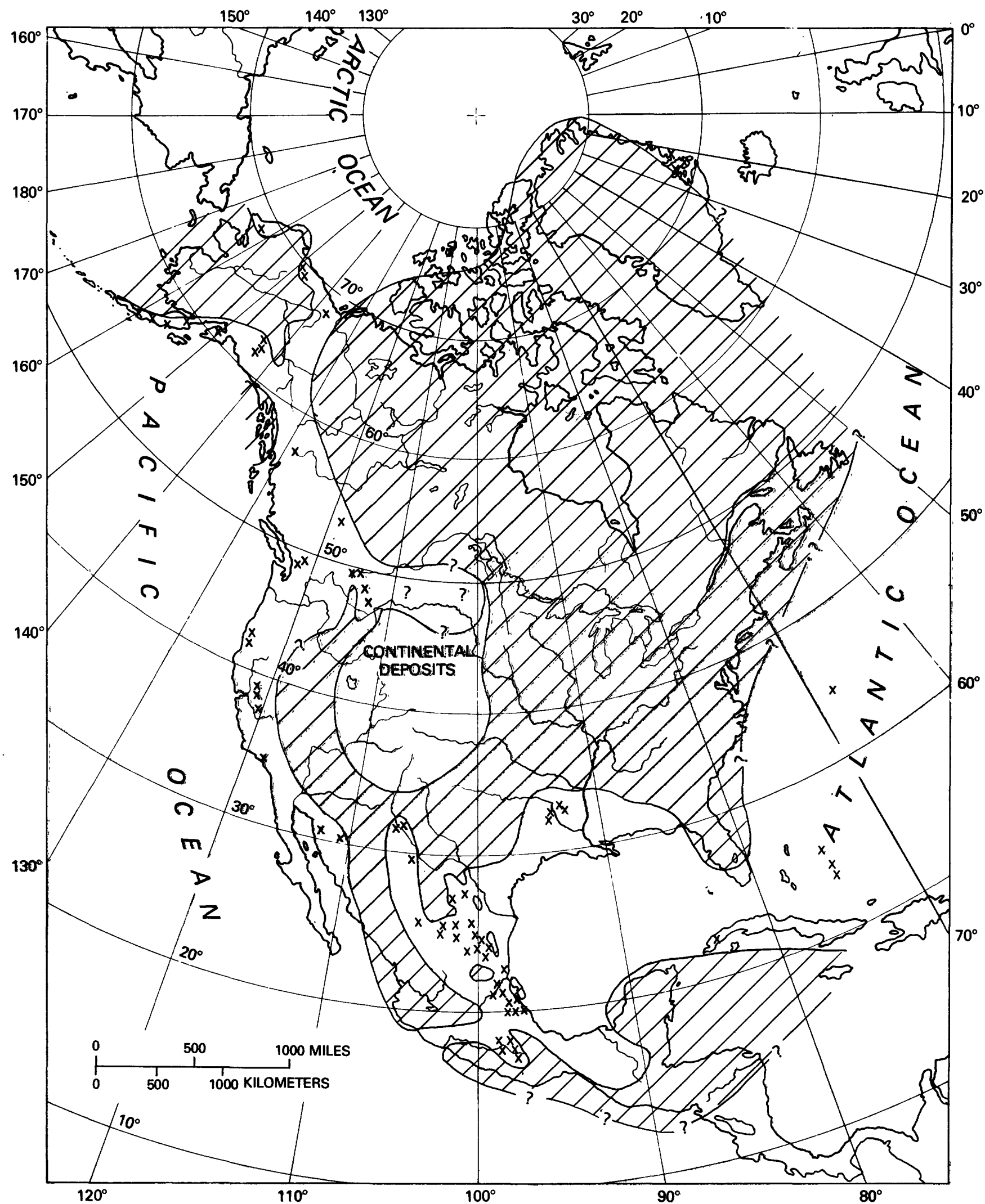

FIGURE 10.-Distribution of late middle Oxfordian to early Kimmeridgian fossils (ammonites and buchias) (X) and inferred seas in North America. Land areas are ruled. 


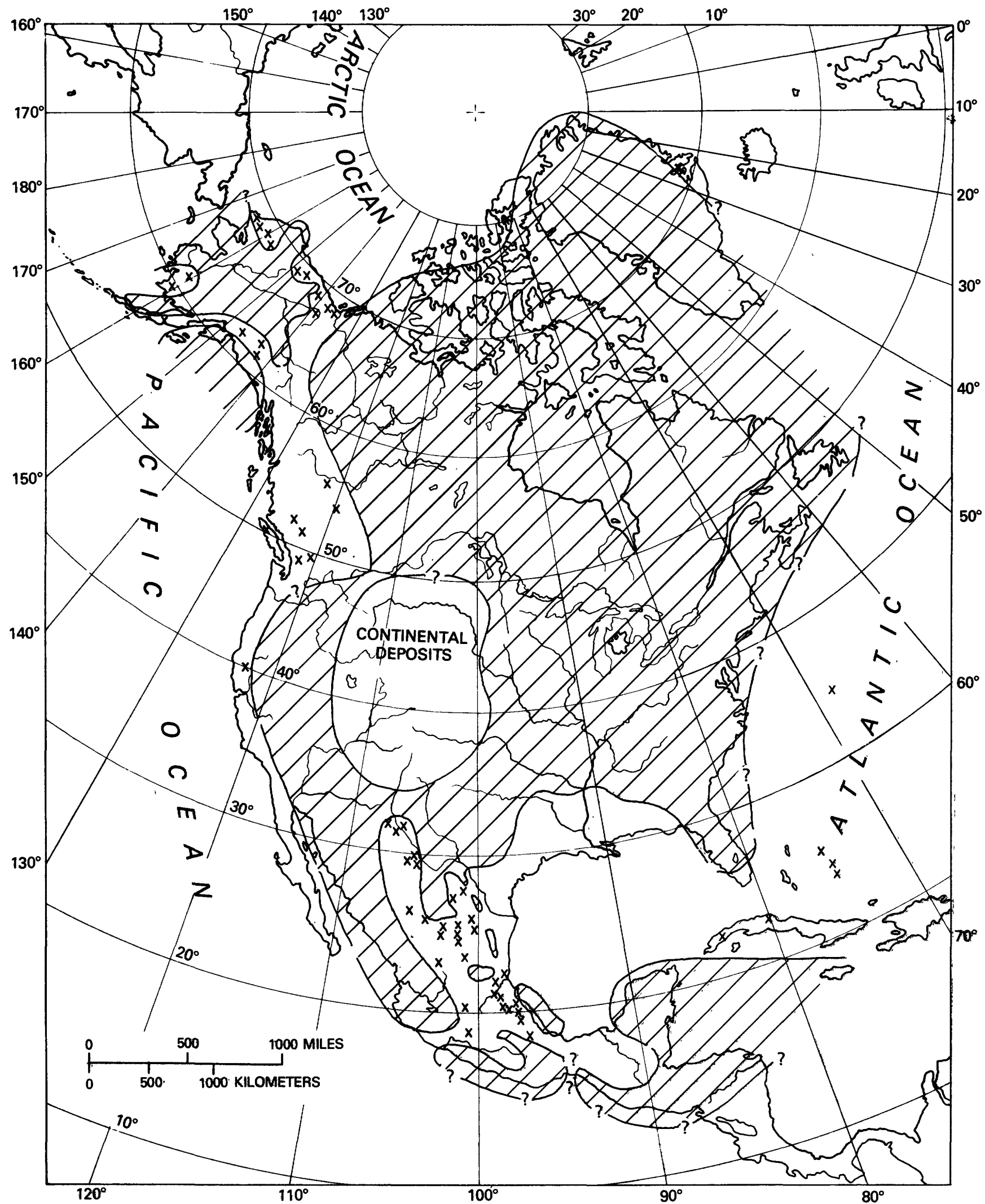

FIGURE 11.-Distribution of late Kimmeridgian to early Tithonian fossils (ammonites and buchias) (X) and inferred seas in North America. Land areas are ruled. 


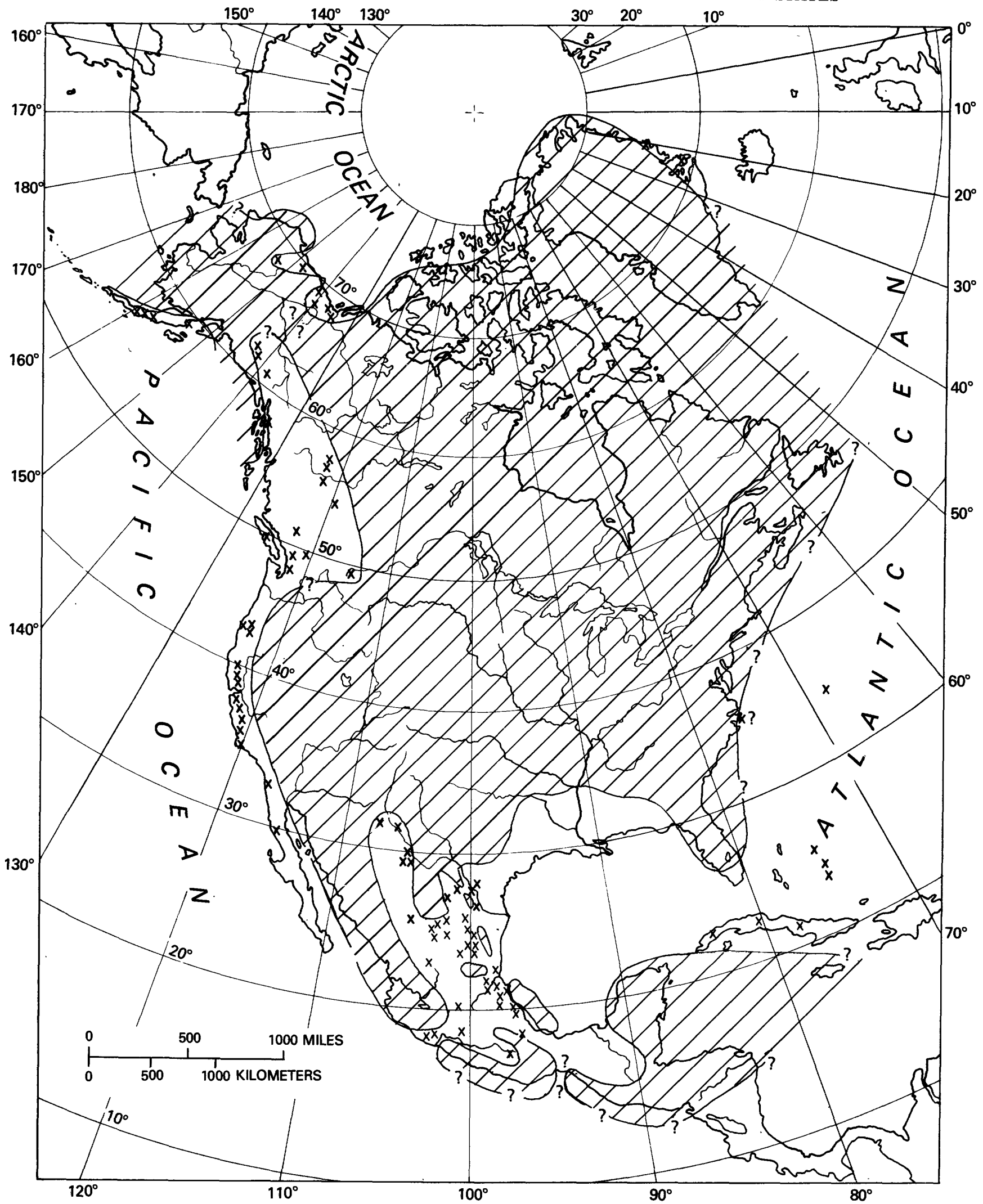

FIGURE 12.-Distribution of late Tithonian fossils (ammonites and buchias) (X) and inferred seas in North America. Land areas are ruled. 
Early Jurassic age occur in southern and east-central Mexico and perhaps as far north as Catorce (Burckhardt, 1930 , p. 8-44, 91-93; Erben, 1957a, 1957b). In éastcentral Mexico, these beds contain ammonites of Sinemurian and early Pliensbachian Age and were deposited in an embayment (Huayacocotla) that opened only to the Gulf of Mexico, according to Erben (1957b, p. 38), but only to the Pacific Ocean according to Viniegra O. (1971, p. 484) and Lopez Ramos (1974, p. 381-386). In southern Mexico, one ammonite of Early Jurassic age (late Pliensbachian) from the state of Guerrero (Erben, 1954, p. 5-12, pl. 1, figs. 4,5) is the sole evidence for beds of that age near the Pacific Coast. Beds of Early Jurassic age have not been identified in Cuba or in the subsurface of the southern United States.

Marine beds of Bajocian and Bathonian Age have been identified definitely in Mexico only in northwestern Oaxaca and northeastern Guerrero (Burckhardt, 1927; 1930, p. 25, 26; Erben, 1957a, p. 49, 50). They were deposited in an embayment (Guerrero) that probably opened into the Pacific Ocean rather than into the Gulf of Mexico (Erben, 1956b, p. 122-124, pl. 17; 1957b, p. 39, fig. 2; Viniegra O., 1971, p. 484, 492). Marine beds of late Bathonian Age may occur also in the subsurface of east-central Mexico near Tampico, as shown by the presence of some small ammonites similar to the late Bathonian Wagnericeras (Cantú Chapa, 1969, p. 5).

Elsewhere in the Gulf region, a Bajocian to Bathonian Age seems probable for part of the San Cayetano Formation of Cuba (Meyerhoff, 1964, p. 152-153; Krommelbein, 1956; Khudoley and Meyerhoff, 1971, p. 37, 38) but most unlikely for the Louann Salt of the southern United States or for similar bedded salt deposits of southeastern Mexico (Imlay, 1943a, p. 1438; 1953c, p. 7; Viniegra O., 1971, p. 482).

Marine beds of Callovian Age have been found in Mexico only in its east-central and southern areas (Burckhardt, 1927; 1930, p. 26, 32-36, 43; Erben, 1956b, p.12-16, 31, 38; 1957a, p. 46-50; Cantú Chapa, 1969, p. 5,$6 ; 1971$, p. $21-24,36-38$ ). Those beds in the eastcentral area may have been deposited in an arm of the Gulf of Mexico (Erben, 1957b, fig. 2) but more probably represent a transgression from the Pacific Ocean (Viniegra $0 ., 1971$, p. 484, 492). Those beds in the southern area were deposited in waters that definitely connected with the Pacific Ocean (Erben, 1957b, p. 39-40, fig. 2). Marine beds of Callovian Age probably are also present in Cuba (Meyerhoff, 1964, p. 151, 152; Khudoley and Meyerhoff, 1971, p. 60), but the fossil evidence has not yet been published.

Later Jurassic beds of Oxfordian to Tithonian Age are widely distributed throughout the lands bordering the Gulf of Mexico (Burckhardt, 1930; Imlay, 1940b, 1943a, p. 1411-1422; 1953a, p. 20-61, figs. 4, 5; Murray, 1961, p. 287-297; Khudoley and Meyerhoff, 1971, p. 59-67; Maher and Applin, 1968, p. 9-11; Rainwater, 1967). The Gulf of Mexico of that time must have had marine connections with the Atlantic Ocean via Cuba and southern Florida. It must also have been connected with the Pacific Ocean either through southern Mexico or Central America, or both (Viniegra O., 1971, p. 484, 486, fig. 10), judging from the similarities between the marine faunas in Mexico and California. The Gulf of Mexico during Late Jurassic time was separated from the seas in the western interior region by highlands that extended across parts of central Arizona and New Mexico (Harshbarger and others, 1957, p. 43, 44).

\section{PACIFIC COAST}

Jurassic rocks near the Pacific Coast of Mexico have been found only in the states of Oaxaca and Guerrero, as discussed above, and in northwestern Sonora (Burckhardt, 1930, p. 23, 24, 41, 42; Erben, 1957b, p. 36; King, 1939, p. 1645-1659; Imlay, 1952a, p. 972). Farther north in the Pacific Coast region, many Jurassic outcrops are found between southern California and westernmost Alaska.

Northward through Nevada and California into southwestern Oregon, the distribution of outcrops of the various stages indicates that the Jurassic seaways gradually shifted westward (Taliaferro, 1942, fig. 2 on p. 80; Imlay, 1959a, p. 103-106). Thus, in the Sierra Nevada, beds of Callovian Age extend westward beyond beds of Bajocian and Early Jurassic age. Beds of Oxfordian to early Kimmeridgian Age occur with beds of Callovian Age in the foothills of the Sierra Nevada but crop out also at two places west of the Callovian beds (Santa Monica Mountains and Klamath Mountains). Beds of Tithonian Age crop out only in western California and in southwestern Oregon. Only in southwestern Oregon have they been found in the same sequence with beds of Oxfordian to early Kimmeridgian Age.

In east-central Oregon is a thick Jurassic sequence (Dickinson and Vigrass, 1965), ranging in age from Hettangian to early Callovian (Imlay, 1964a, 1968, 1973), that correlates faunally with thick Jurassic sequences in the Sierra Nevada, California, and in the Cook Inlet region, Alaska. In extreme northeastern Oregon and in the adjoining part of Idaho, along the Snake River, are beds of early Oxfordian Age containing Cardioceras (Imlay, 1964a, p. D6, D15). Of paleogeographical interest is the fact that rocks of that particular age have not been identified in California or in southwestern Oregon but have been identified faunally at various places in British Columbia, Alberta, Montana, and Alaska. 
In Washington, Upper Jurassic beds have been found only in three areas in the northern part of the State. Northward from Washington into Alaska, beds of Early, Middle, and Late Jurassic age are widespread, although in some areas certain stages are not represented or have not been identified faunally.

\section{WESTERN INTERIOR REGION}

Marine beds of Early Jurassic age have been identified in the western interior region of Canada as far east as westernmost Alberta (Frebold, 1957, p. 5-12; 1964d, p. 24-26; 1969). They probably were never deposited much farther east or southeast, and they have not been found in the western interior of the United States. Faunally, they represent only parts of the Sinemurian, Pliensbachian, and Toarcian Stages.

Marine beds of earliest Bajocian Age have not been identified definitely by fossils in the western interior of the United States or Canada. In fact, they have not even been found in the eastern half of British Columbia along a line drawn from Whitesail Lake southeastward to Taseko Lakes (Frebold, 1951b, p. 18, 19; 1964d, p. 26; Frebold and Tipper, 1970, p. 9,10). The projection of this line farther southeast coincides approximately with the easternmost occurrence of lower Bajocian beds in eastern Oregon. Nonetheless, an early to early middle Bajocian Age for the Gypsum Spring Formation (or member) in the western interior region is indicated by its position unconformably below a limestone whose middle and upper parts contain late Bajocian ammonites (Imlay, 1967b, p. 19, 26, 27).

By contrast, marine Jurassic beds of middle Bajocian to late Oxfordian or early Kimmeridgian Age are widespread in the western interior of the United States, and, with the exception of the late Bajocian, are equally widespread in Canada. These beds were deposited in an embayment that spread eastward from the Pacific Coast region acress the northernmost part of the United States and adjoining parts of Canada. At one time it was thought that the embayment in the western interior of Canada was partially separated from the Pacific Ocean by a landmass (Schuchert, 1923, p. 226, fig. 14; Crickmay, 1931, p. 89, map 10) whose position coincided approximately with the present Rocky Mountain trench. Recently, however, Frebold (1954; 1957, p. 37-41; Frebold and others, 1959 , p. 12-16) has presented evidence showing that such a landmass did not exist. In contrast with conditions in Canada, however, ample evidence exists that at least the southern part of the embayment in the western interior of the United States was bounded on the west by low landmasses or islands, or both, which furnished some sand and pebbles from late Bajocian until Oxfordian time (Imlay, 1950 , p. $37-42$; 1952c, p. $79-82$; 1953d, p. 54-
59). The position of these landmasses coincides fairly well with that of the Paleozoic Antlers uplift (Roberts and others, 1958, p. 2825, 2850, 2851). Similarly, other landmasses surrounding the Jurassic embayment on its southern, eastern, and northern sides furnished most of the clastic sediment that was deposited in the embayment.

Major marine transgressions took place during middle to late Bajocian, late Bathonian to early Callovian, and early Oxfordian time. Regressions occurred during early Bathonian, middle Callovian, and middle Oxfordian to early Kimmeridgian time. Sedimentation was interrupted marginally during the Bathonian (Imlay, 1956a, p. 564, 579-580) and regionally during the late Callovian (Imlay, 1952b, p. 1747-1752; 1956a, p. 591; 1957, p. $475 ; 1967 b$, p. $53-57)$.

The latest Jurassic marine regression began near the middle of Oxfordian time, as shown by the presence of the early Oxfordian ammonite Cardioceras less than 20 feet $(6 \mathrm{~m})$ below the base of the continental Morrison Formation of Late Jurassic age in the Wind River and Bighorn Basins.

Farther north in northwestern Montana and in Canada, marine deposition continued into late Oxfordian or early Kimmeridgian time, as shown by the presence of Buchia concentrica (Sowerby) (Imlay, 1954, p. 60; 1956a, p. 595; Frebold, 1953, p. 1238, 1239; 1957, p. 68, Frebold and others, 1959, p. 10,11) considerably below the top of the marine sequence. Furthermore, near Fernie, British Columbia, a large ammonite, Titanites, of early late Tithonian Age has been found (Frebold, 1957, p. 36, 66, 67; Frebold and Tipper, 1970, p. 14-17; Westermann, 1966). It appears, therefore, that marine waters disappeared from most of the western interior region of the United States by the end of early Oxfordian time but persisted in northern Montana into late Oxfordian time, and in the western interior of Canada, until late Tithonian time.

The characteristics and distribution of the Jurassic sediments were greatly influenced by tectonic features in the Jurassic embayment (Imlay, Gardner, and others, 1948; Nordquist, 1955; McKee and others, 1956, pl. 8; Imlay, 1957, p. 470-477; J. A. Peterson, 1957, p. 401$404 ; 1972$, p. 177). These include broad gentle uplifts in north-central Montana (Belt Island) and west-central Colorado (Uncompahgre uplift); the large Williston basin in eastern Montana, western North Dakota, and adjoining parts of Canada; the Alberta trough extending northward from Belt Island across northwestern Montana far into Canada; the Twin Creek trough extending south from Belt Island along the Wyoming-Idaho border into north-central Utah; the Sheridan arch extending northeast from north-central Wyoming into southeastern Montana and separating the Williston basin from the Powder River basin (J. A. Peterson, 1954a, p. 474, 477, 
489); and the Hardin trough (J. A. Peterson, 1954a, p. $474 ; 1957$, p. 403), which connects the Williston basin with the Twin Creek trough across northwestern Wyoming. Of these tectonic features, Belt Island had the greatest influence on the marine currents, salinities, and temperatures because of its geographic position and its large size, but it supplied very little clastic sediment (Imlay, Gardner, and others, 1948; J. A. Peterson, 1957, p. 403).

\section{ARCTIC REGION}

Beds of Early to Late Jurassic age in northern Alaska (Imlay, 1955) bear a succession of ammonites similar to that in northern Canada (Frebold, 1958; 1960; 1961, p. 6-24; 1964a, c; Tozer, 1960, p. 9-12, 15, 19, 20). The ammonite successions of these regions do not include any ammonite faunules resembling those of middle to late $\mathrm{Ba}$ jocian, Bathonian, or late Callovian Age in northwest Europe. The Bathonian is represented faunally, however, by the ammonite genera Arcticoceras, Arctocephalites, and Cranocephalites, as in East Greenland and arctic U.S.S.R. This age determination is based on their stratigraphic position below beds of early Callovian Age in Greenland (Callomon, 1959).

In southern Alaska, the basal Hettangian is represented by the ammonite Waehneroceras at Wide Bay and Puale Bay on the Alaska Peninsula, in the Seldovia area south of Cook Inlet, and in the southern part of the Wrangell Mountains. Psiloceras occurs in those same mountains and also north of Old Rampart near the Porcupine River in northeastern Alaska. The Hettangian is probably represented also on Hagermeister Island and in the Kuskokwim area by pelecypods identical with species found in the basal Jurassic near Seldovia (Imlay and Detterman, 1973, p. 22). The lack of Hettangian ammonites in most of northern Alaska is matched by a similar lack in arctic Canada and in East Greenland. To date, the presence of Hettangian deposits in northern Alaska is based on one specimen of Psiloceras (Franziceras) obtained from a core at the depth of 2,170.5 feet $(661.6 \mathrm{~m})$ in the South Barrow test well 12, about 10 miles $(16 \mathrm{~km})$ southeast of Point Barrow.

\section{SUCCESSION OF AMMONITES AND BUCHIAS BY STAGES}

\section{HETTANGIAN}

In Mexico, the Hettangian Stage has not been identified faunally. The presence of one ammonite similar to the Hettangian genus Psiloceras is not valid evidence of such an age because of its association with the early $\mathrm{Si}$ nemurian ammonite Coroniceras (Flores López, 1967, p. $26,29,30$, pl. 8, fig. 1).
In western Nevada and eastern Oregon, the basal Jurassic has furnished ammonite genera that specifically and stratigraphically correspond close to Hettangian ammonites in Europe (Muller and Ferguson, 1939, p. 1611, chart opposite p. 1590; Corvalan, 1962; Hallam, 1965, p. 1485-1487, 1494). These include, in particular, the genera Waehneroceras and Psiloceras in the lower part of the Hettangian sequence and the genera Schlotheimia, Caloceras, and Alsatites in the upper part.

\section{SINEMURIAN}

In east-central Mexico, the highest and lowest parts of the Sinemurian are represented by ammonites closely similar to or identical with ammonites in Europe (Burckhardt, 1930, p. 8-23; Erben, 1956a, p. 124-149; 1957a, p. 44; Flores López 1967, p. 29, 30). No evidence exists, however, for the presence of the European zones of Caenisites turneri and Asteroceras obtusum (Hallam, 1965, p. 1491-1493).

In northwestern Mexico near El Antomonio, Sonora, the early Sinemurian is represented by Arnioceras (Imlay, 1952a, p. 973). Pelecypods of Hettangian or Sinemurian Age are present in west-central and southern Sonora (Burckhardt, 1930, p. 23, 24, 41, 42; King, 1939, p. $1655-1659$, pl. 5). The late Sinemurian is probably represented by Crucilobiceras about 25 miles $(40 \mathrm{~km})$ south-southeast of Caborca, on the basis of collections made by L. T. Silver (California Inst. Technology).

In western Nevada, the Sinemurian succession is nearly the same as that in eastern Mexico; it has the same faunal gaps and includes similar species, some of which may be identical with species in Mexico and Europe (Muller and Ferguson, 1939, p. 1611, 1612, table 3). Similar faunal successions have been found also in eastern Oregon, western and northwestern Canada, and southern and northern Alaska. (See fig. 13.) Nearly all successions contain ammonites representing the highest and lowest parts of the Sinemurian (Frebold, 1957, 1959, 1966, 1975; Frebold and Tipper, 1970) but lack any evidence for much of the middle part of the stage. Thus, the European Caenisites turneri zone has been identified only in the Wrangell Mountains, Alaska (Imlay and Detterman, 1973, p. 22); the Asteroceras obtusum zone, only in southern British Columbia (Frebold, 1964d); and the Oxynoticeras oxynotum zone, only in the Richardson Mountains of northwestern Canada (Frebold, 1960, p. 16, pl. 4, figs. 1-5).

\section{PLIENSBACHIAN}

Ammonites of Pliensbachian Age have been found in southeastern and south-central Mexico, western Nevada (Muller and Ferguson, 1939, p. 1621, 1622; Silberling, 


\begin{tabular}{|c|c|c|c|c|c|c|c|}
\hline \multicolumn{2}{|c|}{ Stages } & $\begin{array}{l}\text { Northwest European } \\
\text { ammonite zones } \\
\text { (after Dean and others, 1961) }\end{array}$ & $\begin{array}{c}\text { Eastern and } \\
\text { southern Mexico } \\
\text { (Erben, 1956a, } \\
1957 \text { a } \\
\text { Hallam, 1965) }\end{array}$ & $\begin{array}{l}\text { Western Nevada } \\
\text { (Muller and } \\
\text { Ferguson, 1939; } \\
\text { Hallam, 1965) }\end{array}$ & $\begin{array}{c}\text { East-central } \\
\text { Oregon } \\
\text { (Imlay, 1968) }\end{array}$ & $\begin{array}{c}\text { Canadian Rocky } \\
\text { Mountains } \\
\text { (Frebold, 1969; } \\
\text { Frebold and Tipper, } \\
1970 \text { ) }\end{array}$ & $\begin{array}{l}\text { British Columbia, } \\
\text { southern part, } \\
\text { including islands } \\
\text { (Frebold, 1964a, d; } \\
\text { Frebold and } \\
\text { Tipper, 1970) }\end{array}$ \\
\hline \multirow{3}{*}{\multicolumn{2}{|c|}{ 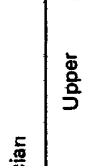 }} & Dumortieria lavesquei & \multirow{6}{*}{$\begin{array}{l}\text { Lower part } \\
\text { of coal and } \\
\text { plant-bearing } \\
\text { beds }\end{array}$} & \multirow{2}{*}{$\begin{array}{c}\text { Grammoceras } \\
\text { and } \\
\text { Pseudolioceras }\end{array}$} & $\begin{array}{c}\text { Catulloceras } \\
\text { and Dumortieria? }\end{array}$ & \multirow{2}{*}{$\begin{array}{c}\text { Phylseogrammoceras } \\
\text { and } \\
\text { Gremmoceras }\end{array}$} & \multirow{2}{*}{$\begin{array}{c}\text { Phylseogrammoceres } \\
\text { and } \\
\text { Grammoceras }\end{array}$} \\
\hline & & Grammoceras thouersense & & & & & \\
\hline & & Haugia variabilis & & \multirow{2}{*}{$\begin{array}{l}\text { Catecoeloceras } \\
\text { and } \\
\text { Dactylioceras }\end{array}$} & $\begin{array}{l}\text { Heugia and } \\
\text { Polyplectus }\end{array}$ & \multirow{2}{*}{$\begin{array}{l}\text { Phymatoceras } \\
\text { and } \\
\text { Paronoceres }\end{array}$} & \\
\hline \multirow[t]{3}{*}{$\stackrel{\text { \% }}{\circ}$} & \multirow{3}{*}{ 产 } & Hildoceras bifrons & & & & & \\
\hline & & Harpoceras falcifer & & \multirow{2}{*}{ Nodicoeloceres } & & \multirow{2}{*}{$\begin{array}{l}\text { Harpoceras } \\
\text { cf. H. exaretum and } \\
\text { Dactylioceres }\end{array}$} & \multirow{2}{*}{$\begin{array}{l}\text { Harpoceres } \\
\text { cf. H. exaratum and } \\
\text { Dactylioceres }\end{array}$} \\
\hline & & Dactylioceras tenuicostetum & & & & & \\
\hline \multirow{5}{*}{ 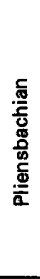 } & \multirow{2}{*}{ 高 } & Pleuroceras spinatum & \multirow{2}{*}{$\begin{array}{c}\text { Arieticeras } \\
\text { (Guerrero embayment } \\
\text { only) }\end{array}$} & \multirow{2}{*}{ Arieticeres } & \multirow{2}{*}{$\begin{array}{l}\text { Arieticeras, Reynes- } \\
\text { oceres, Peltarpites, } \\
\text { Prodactylioceras, } \\
\text { and Lepteleoceras }\end{array}$} & $\begin{array}{l}\text { Pleuroceras and } \\
\text { Dactylioceras }\end{array}$ & \\
\hline & & Ameltheus mergaritatus & & & & Ameltheus & \\
\hline & \multirow{3}{*}{ 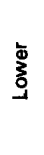 } & Prodactylioceras devoei & & & & & \\
\hline & & Tregophylloceras ibex & & & & & Fanninoceres \\
\hline & & Uptonie jamesoni & Uptonia? & Uptonie? & & Phricodoceras & $\begin{array}{l}\text { Acanthop/euroceras, } \\
\text { Uptonia, Trppidoceras }\end{array}$ \\
\hline \multirow{6}{*}{ 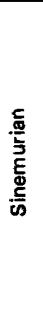 } & \multirow{3}{*}{$\begin{array}{l}\text { ळ } \\
\text { 윽 }\end{array}$} & Echioceras raricostatum & $\begin{array}{c}\text { Crucilobiceres? } \\
\text { Echioceres } \\
\end{array}$ & $\begin{array}{l}\text { Eoderoceras and } \\
\text { Crucilobiceres }\end{array}$ & $\begin{array}{l}\text { Eoderoceras and } \\
\text { Crucilobiceres }\end{array}$ & $\begin{array}{c}\text { Eoderoceres and } \\
\text { Gleviceras }\end{array}$ & Echioceres \\
\hline & & Oxynoticeras oxynotum & Oxynoticeras & Oxynoticeres & & & \\
\hline & & Asteroceras obtusum & & & & & Asteroceras \\
\hline & \multirow{3}{*}{ 高 } & Caenisites turneri & & & & & \\
\hline & & Arnioceras semicostatum. & Arnioceras & \multirow{2}{*}{$\begin{array}{c}\text { Arnioceres, } \\
\text { Arietites, } \\
\text { Coroniceras, and } \\
\text { Megerietites }\end{array}$} & Arnioceres & \multirow{2}{*}{$\begin{array}{l}\text { Arietites } \\
\text { and } \\
\text { Arnioceres }\end{array}$} & \multirow{2}{*}{$\begin{array}{l}\text { Coroniceras } \\
\text { bisulcatum and } \\
\text { Arnioceras }\end{array}$} \\
\hline & & Arietites bucklandi & Coroniceras & & & & \\
\hline \multirow{3}{*}{\multicolumn{2}{|c|}{ 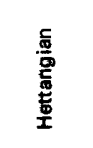 }} & Schlotheimia anguleta & \multirow{3}{*}{ Not exposed } & Schlotheimia & Schlotheimie & \multirow{3}{*}{ Probably absent } & \multirow{2}{*}{$\begin{array}{c}\text { Psiloceras canadense, } \\
\text { Paracaloceres, and } \\
\text { Charmasseiceras }\end{array}$} \\
\hline & & Alsatites liasicus & & $?$ & $?$ & & \\
\hline & & Psiloceras planorbis & & $\begin{array}{l}\text { Waehneroceras } \\
\text { and Psiloceres }\end{array}$ & $\begin{array}{l}\text { Waahneroceres } \\
\text { and Psiloceras }\end{array}$ & & $\begin{array}{l}\text { Psiloceras } \\
\text { aff. P. planorbis }\end{array}$ \\
\hline
\end{tabular}

A. Mexico to southern British Columbia.

FIGURE 13.-SUCCESSION AND CORRELATION OF

1959, p. 26-29; Corvalán, 1962; Hallam, 1965, p. 14851488), east-central California (Clark and others, 1962, p. B19), east-central Oregon, both southern and northern Alaska (fig. 13) (Imlay, 1952a, p. 981; 1955, p. 87; Howarth, 1958, p. XXVI), and in western and northwestern Canada.

The faunal evidence for the Pliensbachian in Mexico is meager. It consists only of two fragments resembling Uptonia from Puebla (Erben, 1956a, p. 365, pl. 41, figs. 14, 15) and of one specimen of Arieticeras from Guerrero (Erben, 1954, p. 5, pl. 1, figs. 4, 5).

Bed of early Pliensbachian Age have not been identified faunally in Oregon or California, and their presence in Nevada is questionable. Beds of late Pliensbachian Age in Nevada contain the ammonite Arieticeras. Such beds in Oregon and California contain the ammonites Reynesoceras, Arieticeras, Fontanelliceras, Canavaria, Protogrammoceras, Fuciniceras, Leptaleoceras, Prodactylioceras, Tragophylloceras, Fanninoceras, Liparoceras (Becheiceras), and Paltarpites. With these am- monites in the upper part of their range are some specimens of Dactylioceras. This assemblage is characterized by an abundance of genera of the families Dactylioceratidae and Hildoceratidae and by an absence of the Amaltheidae. In these respects this assemblage shows much more resemblance to the late Pliensbachian ammonites of the Mediterranean region than to those of northwest Europe. Its age until recently was considered to be early Toarcian (Hallam, 1965, p. 1485-1488; Dickinson and Vigrass, 1965, p. 37, 41), but the association of genera listed previously is excellent evidence for a late Pliensbachian Age.

In Alaska, by contrast, the beds of late Pliensbachian Age contain genera of the family Amaltheidae, such as Amaltheus and Pleuroceras, that are specifically identical with or closely similar to species in northwestern Europe. Faunally, the late Pliensbachian ammonites of Alaska have much more in common with ammonites of that age in northwestern Europe than with ammonites in Oregon and California. 


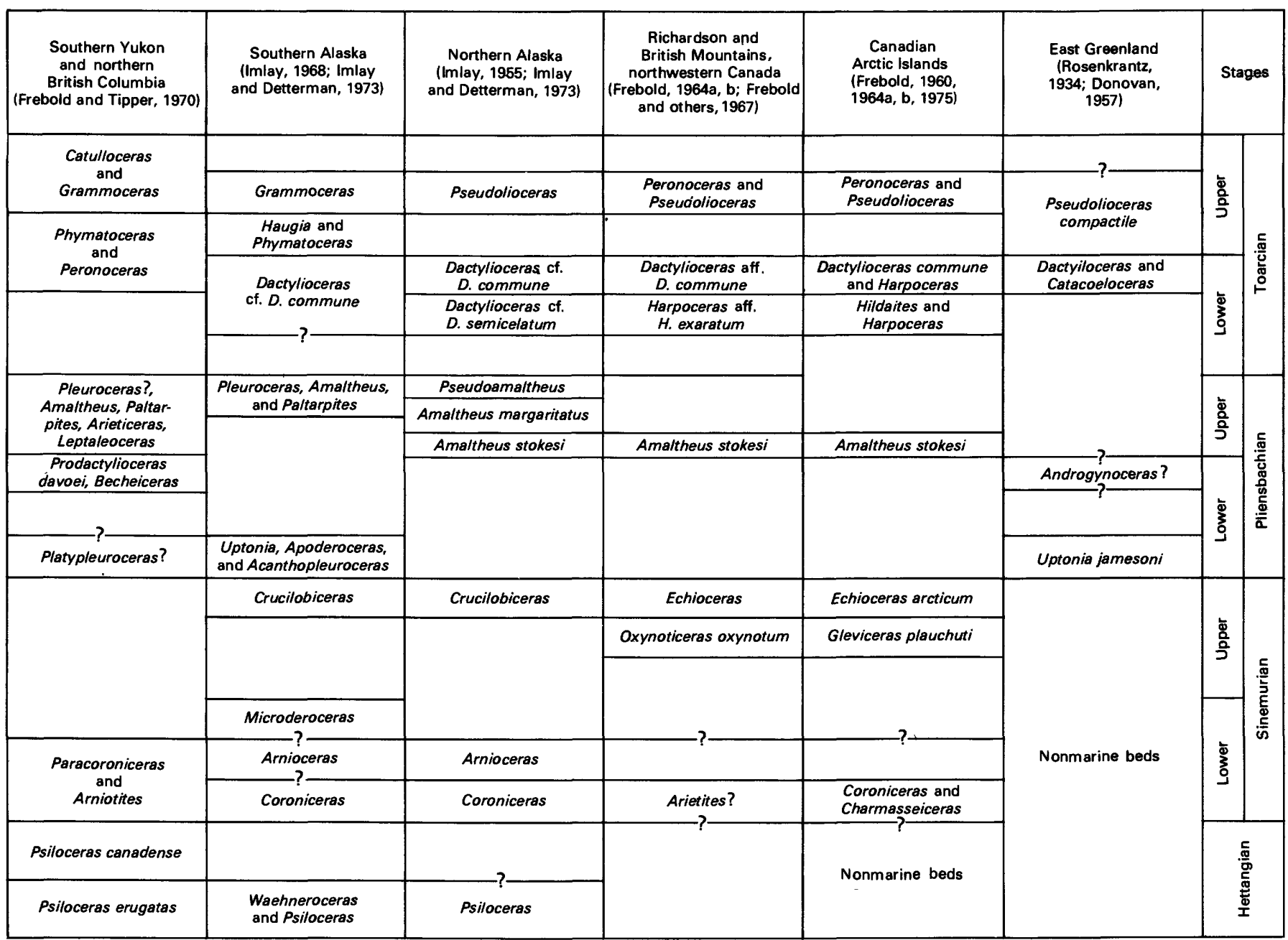

B. Northern British Columbia to East Greenland.

HETTANGIAN TO TOARCIAN AMMONITES IN NORTH AMERICA.

In western Canada, most parts of the Pliensbachian Stage are represented in at least one of the sequences exposed in the Rocky Mountains, British Columbia, and the northern Yukon. (See fig. 13.) The lower Pliensbachian is best known from the Queen Charlotte Islands (Frebold, 1967a, p. 1146, 1147; Frebold and Tipper, 1970, p. 4-6). The middle and upper Pliensbachian are best known from northern British Columbia and the southern Yukon (Frebold, 1964d, p. 25; Frebold and Tipper, 1970, p. 6).

In arctic Canada, the Pliensbachian is represented to date only by an occurrence of Amaltheus stokesi in the British Mountains, Yukon Territory (Frebold and others, 1967). This species furnishes an accurate correlation with the upper Pliensbachian ammonite sequence in northern Alaska and in Europe.

\section{TOARCIAN}

Ammonites of Toarcian Age have been found in the United States in the same general areas as ammonites of
Pliensbachian Age (fig. 13). They greatly resemble the ammonites in Toarcian beds in Europe in appearance and in stratigraphic succession.

In western Nevada, Toarcian ammonites have been found at several places, and a fairly complete sequence of Toarcian beds has been identified near Westgate (Muller and Ferguson, 1939, p. 1621; Corvalán, 1962; Hallam, 1965, p. 1486-1488). At this place, correlation with the lower, middle, and upper parts of the Toarcian Stage of Europe is furnished by the presence of an ammonite succession consisting of Nodicoeloceras, Catacoeloceras, and Grammoceras. Of these, Nodicoeloceras occurs a few feet above Arieticeras of probable late Pliensbachian Age, Catacoeloceras, about 165 feet $(50 \mathrm{~m})$ above Arieticeras, and Grammoceras, about 125 feet (38 $\mathrm{m})$ higher than Catacoeloceras.

In east-central Oregon southwest of John Day, the lower and middle parts of the Toarcian have not been identified faunally. The upper Toarcian is represented, however, by a few ammonites obtained from the basal 


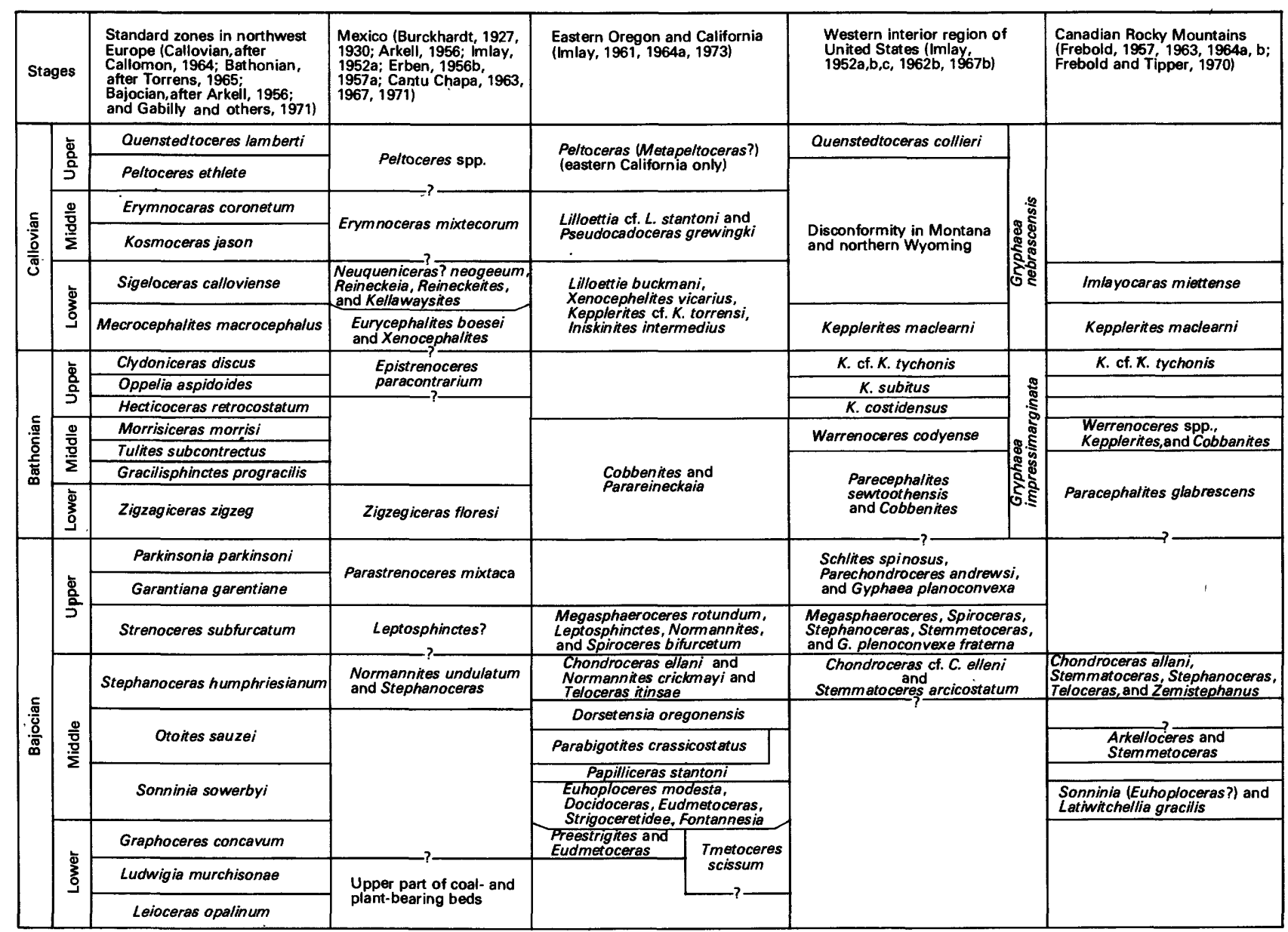

$A$. Mexico to western interior region.

FIGURE 14.-SUCCESSION AND CORRELATION OF

part of the Snowshoe Formation (Dickinson and Vigrass, 1965, p. 49). Of these, Haugia, Polyplectus, and Grammoceras? were obtained about 75 feet $(23 \mathrm{~m})$ above the base of the formation, Polyplectus and Catulloceras, from 100 to 125 feet ( 30 to $38 \mathrm{~m}$ ) above the base, and Dumortieria?, about 125 feet $(38 \mathrm{~m})$ above the base. At one place, Tmetoceras was found $125-200$ feet $(38-61 \mathrm{~m}$ ) above the base of the Snowshoe Formation.

In the Talkeetna Mountains in south-central Alaska northeast of Anchorage, the early Toarcian is represented by both finely and coarsely ribbed species of Dactylioceras, the middle Toarcian, by Haugia and Phymatoceras, and the late Toarcian, by Grammoceras. Available collections do not include any specimens of Dumortieria? or Catulloceras, such as characterized the uppermost Toarcian beds in east-central Oregon.

In northern Alaska, the early Toarcian is represented by the ammonites Nodicoeloceras and Dactylioceras obtained at depths of 1,772 to 2,063 feet (540 to $629 \mathrm{~m}$ ) in the South Barrow test well 3, near Point Barrow (Imlay, 1955 , p. $82,87-88$, pl. 10, figs. 6, 9-16, pl. 12, figs. 12-14). The early Toarcian is represented also by Harpoceras cf. $H$. exaratum (Young and Bird) obtained from outcrops near the Sadlerochit River. The late Toarcian is possibly represented by species of Pseudolioceras resembling $P$. compactile Simpson (Imlay, 1955 , p. 89, pl. 12, figs. 17, 18, 21). The genus Pseudolioceras, however, ranges from early Toarcian to early middle Bajocian and is not very useful as a guide fossil.

In western Canada, the early Toarcian is represented by Harpoceras cf. H. exaratum (Young and Bird) and several species of Dactylioceras; the middle Toarcian, by Phymatoceras and Peronoceras; and the late Toarcian, by Phylseogrammoceras, Grammoceras, and Catulloceras (Frebold and Tipper, 1970, p. 17). These ammonites correlate closely with the Toarcian ammonite succession in southern Alaska.

In arctic Canada, the ammonite succession is likewise similar to that in southern Alaska, except for the presence of Pseudolioceras in its upper part as in northern Alaska and East Greenland (Frebold, 1960, 1964b, 1964c, 1975). 


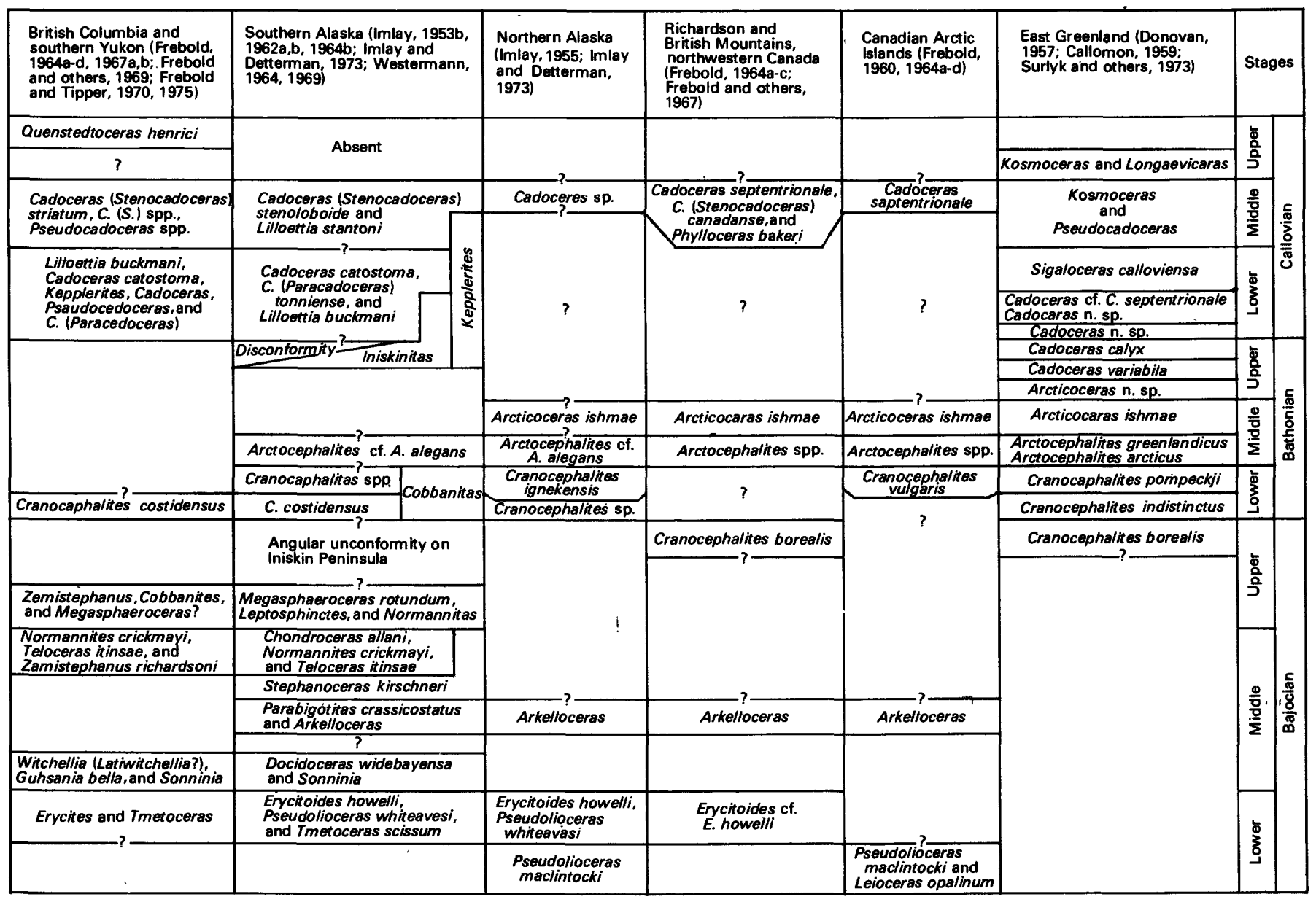

$B$. British Columbia to East Greenland.

BAJOCIAN TO CALLOVIAN AMMONITES IN NORTH AMERICA.

\section{BAJOCIAN}

The only Bajocian ammonites found in southern Mexico are from upper Bajocian strata in northeastern Guerrero and northwestern Oaxaca. Of these, Normannites (Burckhardt, 1927, p. 22, pl. 12, figs. 1-4), in association with Stephanoceras, could represent the Stephanoceras humphriesianum zone of Europe, or the next younger zone. Leptosphinctes? (Burckhardt, 1927, pl. 11, figs. 11, 12) could represent the early late Bajocian. Parastrenoceras mixteca Ochoterena F. (Ochoterena F., 1963, p. 7, pl. 1; Burckhardt, 1927, pl. 16, figs. 10, 11, 16) probably represents some part of the late Bajocian younger than the beds containing Normannites.

Fairly complete and closely similar ammonite successions of Bajocian Age have been found in east-central Oregon (Imlay, 1973, p. 16-31, figs. 3-8) and in southern Alaska (Westermann, 1964, 1969; Imlay, 1962a, 1964b; Imlay and Detterman, 1973, p. 23-24). In neither area is there any faunal evidence for the earliest Bajocian (Lioceras opalinum zone). Otherwise, in both areas, the succession of ammonite genera from Tmetoceras at the base up to Teloceras is remarkably similar to that in Europe and in other parts of the world. Exceptions include a few genera that have been found only in areas bordering the Pacific Ocean (Imlay, 1965, fig. 1 on p. 1024). Among such genera are Pseudotoites, Parabigotites, and Zemistephanus, which occur in stratigraphic succession associated respectively with the genera Docidoceras, Otoites, and Teloceras.

In both southern Alaska and Oregon, beds of late Bajocian Age are identified by the presence of Leptosphinctes and Sphaeroceras. In Oregon, associated ammonites include Spiroceras, Normannites, and Megasphaeroceras. In southern Alaska, associated ammonites include Megasphaeroceras, Oppelia (Lyroxyites), and Normannites (Imlay, 1962a). Of these, Megasphaeroceras and the subgenus Lyroxyites are known only from North America. The presence of Normannites suggests that the fauna is not younger than the earliest late Bajocian. 


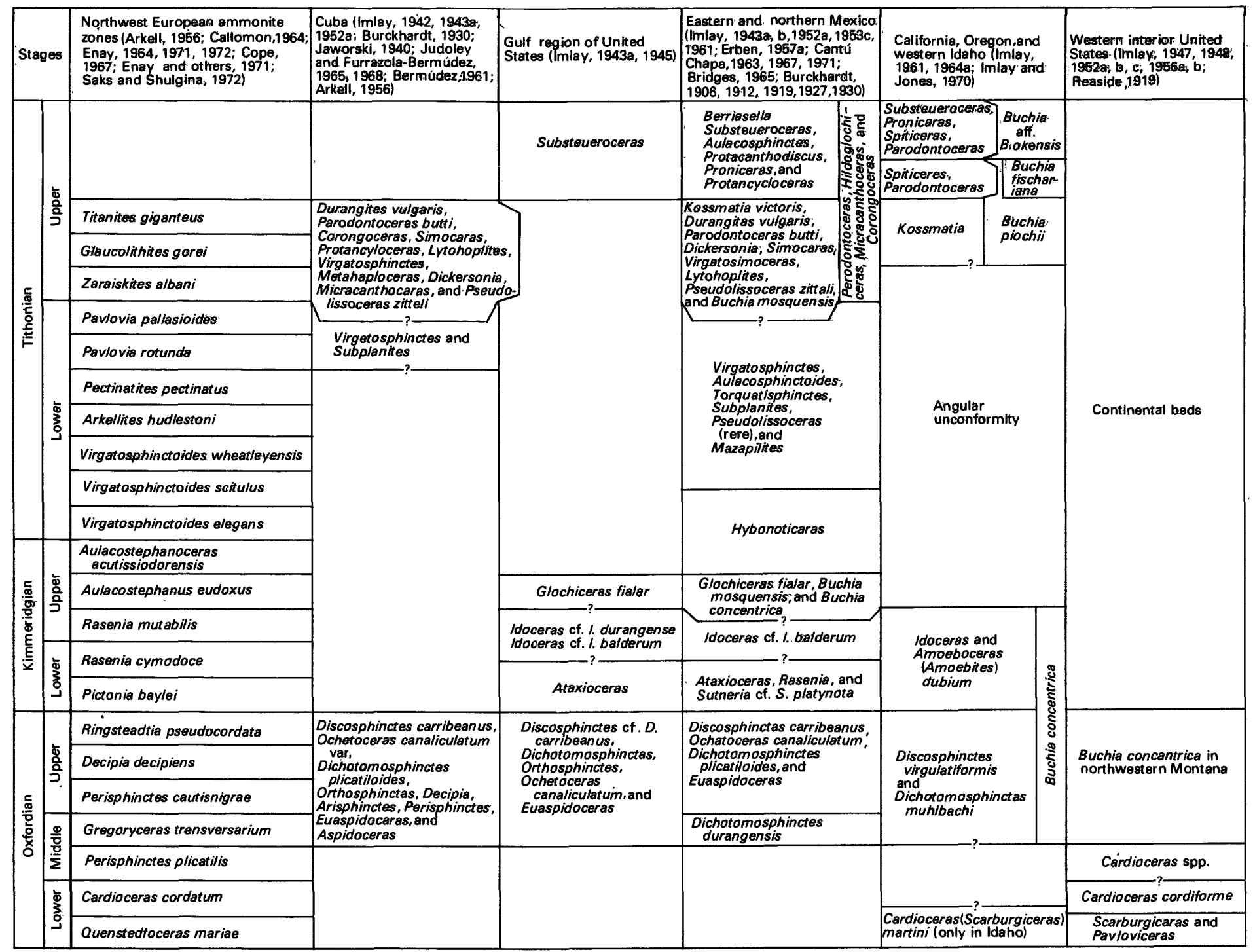

A. Gulf of Mexico, Pacific Coast, and western interior region.

FIGURE 15.-SUCCESSION AND CORRELATION OF

The Bajocian is poorly represented in the western interior of the United States. A middle Bajocian Age, probably corresponding to the European zone of Stephanoceras humphriesianum, is shown by one specimen of Chondroceras and several fragments of Stemmatoceras from the basal part of the shale member of the Sawtooth Formation exposed at Swift Reservoir in northwestern Montana (Imlay, 1948, p. 19, pl. 5, figs. $1-5 ; 1967 \mathrm{~b}$, p. 28). A late Bajocian Age is shown by an association of Spiroceras, Stemmatoceras, Stephanoceras, and Megasphaeroceras in the upper part of the lowermost limestone (Sliderock Member) of the Twin Creek Limestone near the border of Wyoming and Idaho (Imlay, 1967b, p. 28, 29). The association of the first three genera in the Twin Creek Limestone, by comparison with the European faunal succession, indicates a correlation with the basal part of the upper Bajocian.
The presence of Megasphaeroceras furnishes a correlation with lower upper Bajocian beds in southern Alaska. The overlying beds (Rich Member) of the Twin Creek, containing Parachondroceras and Sohlites (Imlay, 1967b, p. 31), are correlated with the uppermost Bajocian on the basis of stratigraphic position and the resemblances of the ammonites to genera of Bajocian Age.

In northern Alaska, only the lower Bajocian and part of the middle Bajocian have been identified. The European zone of Lioceras opalinum is probably represented by Pseudolioceras maclintochi (Haughton) (Westermann, 1964, p. 422-424; Imlay, 1955, p. 89, pl. 12, figs. $15,16)$, which in arctic Canada has been found with Lioceras opalinum (Reinecke) (Frebold, 1958, p. 23; 1960, p. 28). The European zone of Tmetoceras scissum is probably represented by one fragment of Tmetoceras obtained from a test well (Imlay, 1955, p. 89, 90) and by 


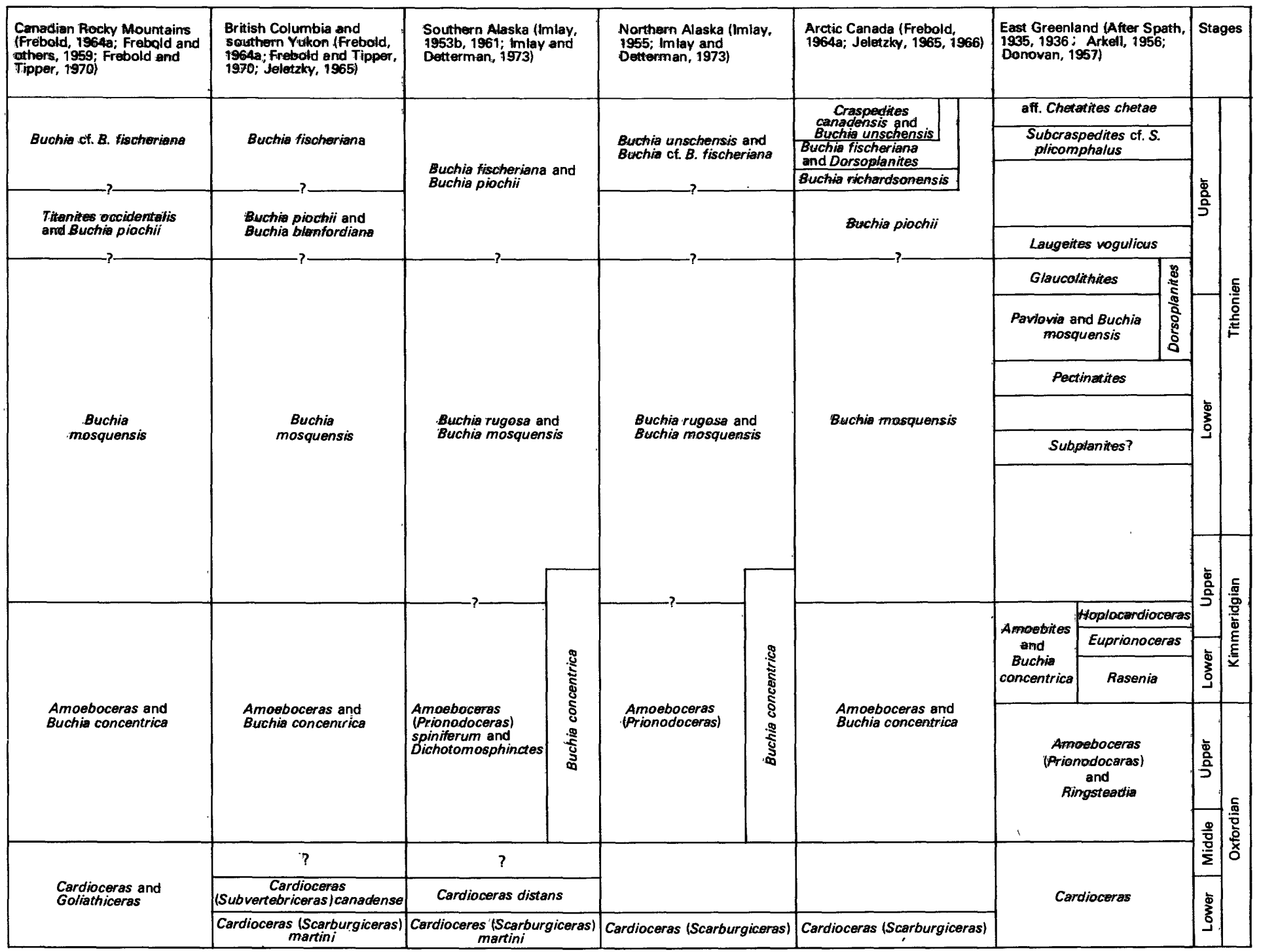

OXFORDIAN TO TITHONIAN AMMONITES IN NORTH AMERICA.

\section{$B$. Southwestern Canada to East Greenland.}

several specimens of Erycitoides obtained from outcrops (Imlay, 1955, p. 90, pl. 13, figs. 12, 13). The middle Bajocian is represented only by Arkelloceras, whose age is based on stratigraphic occurrences on the Alaska Peninsula (Imlay, 1964b, p. B18, B53) and in the Canadian Rocky Mountains (Westermann, 1964, p. 405-409; Frebold and others, 1967, p. 20).

Bajocian ammonites in the Canadian Rocky Mountains, British Columbia, and southern Yukon bear close resemblances specifically and stratigraphically to the $\mathrm{Ba}-$ jocian ammonites in eastern Oregon and in southern Alaska. The main difference is the rarity in western Canada of ammonites of early and late Bajocian Ages and of the Otoites sauzei zone of the middle Bajocian.

In arctic Canada, the Bajocian ammonite sequence is identical with that in northern Alaska, except for the presence of Leioceras opalinum near the base. As in northern Alaska, the only middle Bajocian ammonite present is Arkelloceras.

\section{BATHONIAN}

Lowermost and uppermost Bathonian sediments have been identified in northeastern Guerrero and northwestern Oaxaca, Mexico, on the basis of ammonite evidence. These beds were deposited in an embayment (Guerrero) from the south that apparently connected with the $\mathrm{Pa}$ cific Ocean and did not extend to the Gulf of Mexico (Erben, $1957 b$, p. 35 , 39, fig. 2). The earliest Bathonian is represented by Zigzagiceras floresi Burckhardt (Burekhardt, 1927, p. 25, pl. 12, figs. 14-16, 18-20; Arkell, 1956, p. 564; Erben, 1956b, p. 110, 122; 1957a, p. 50) and the latest Bathonian, by Epistrenoceras paracontrarium 


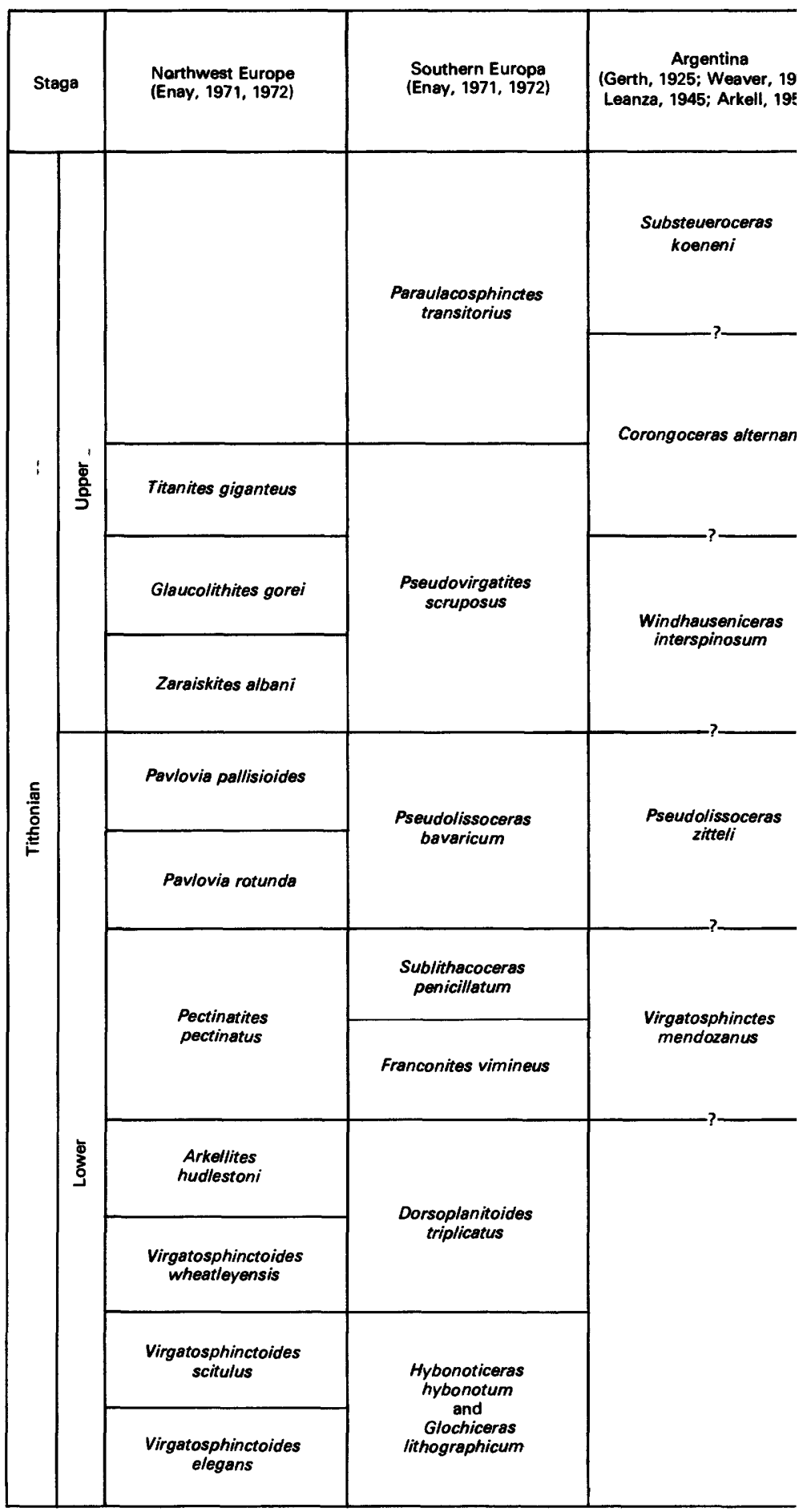

FIGURE 16.-COMPARISONS OF THE TITHONIAN

(Burckhardt) (Burckhardt, 1927, p. 80, 94, 95, pl. 16, lantic Ocean (Erben, 1957b, p. 35, 39, fig. 2), or westfigs. 14, 15; Arkell, 1956, p. 564; Erben, 1956b, p. 119; 1957a, p. 50).

The latest Bathonian is probably also represented in the subsurface of northern Veracruz by some small ammonites resembling Wagnericeras (Cantú Chapa, 1969, p. 5). This occurrence is in the Huayacocotla embayment, which may have been connected eastward with the Atward with the Pacific Ocean, or both.

In the United States, the assignment of certain beds to the Bathonian is based mainly on stratigraphic position, as the ammonites present are mostly generically different from those in the typical Bathonian of Europe.

In eastern Oregon, southwest of John Day, the Bathonian is represented by beds containing Cobbanites, Par- 
must be about the same as that of Cranocephalites in Alaska, as both are associated with Gryphaea impressimarginata McLearn and with the lowest occurrences of Cobbanites (Imlay, 1962b, tables 5 and 6).

The late Bathonian in the western interior of North America is represented by species that were once assigned to Arcticoceras by Imlay (1953a, p. 19-22) because of their general resemblance to that genus in shape and rib pattern. They were subsequently assigned to a new genus, Warrenoceras (Frebold, 1963, p. 13, 14), that differs from Arcticoceras in its narrower umbilicus, less sharp ribs, absence of constrictions, and broader elements of the suture line, and by becoming smooth at a much earlier growth stage. These differences do not justify more than a subgeneric status for Warrenoceras under Arcticoceras, according to J. H. Callomon (written commun., 1972).

The exact age of Warrenoceras is not known. Its general resemblance to Arcticoceras suggests, however, that it is either a provincial time equivalent of Arcticoceras or is a descendant. If so, it could be of the same age or could be younger. Its association with Cadoceras suggests that it is younger than the typical Arcticoceras of the Arctic region. Against such a suggestion, however, is the fact that all species of Cadoceras in the western interior of North America have a rounded instead of a sharp umbilical edge (Imlay, 1953a, p. 3; 1953b, p. 45) and hence may not have the same age significance as $\mathrm{Ca}$ doceras proper. Furthermore, the exact time relationships of Warrenoceras to the older Paracephalites are uncertain because of the presence of a disconformity of unknown magnitude at the base of the Warrenocerasbearing beds in Montana, northern Wyoming, and western South Dakota (Imlay, 1962b, p. C9). Nonetheless, the association of Cobbanites with Warrenoceras in Alberta (Frebold, 1963, p. 5) indicates a Bathonian Age, because Cobbanites in southern Alaska has not been found above beds of Bathonian Age and is closely related to the late Bajocian genus Vermisphinctes.

The late Bathonian in the northern part of the western interior region may be represented also by species of Kepplerites that were assigned previously to "Gowericeras" costidensus Imlay, "G." subitum Imlay, and Kepplerites ef. K. tychonis Ravn (Imlay 1953a, p. 7, 8). This age is indicated by the close resemblance of $K$. costidensus to an undescribed species (No. 3149 in Geological Museum, Univ. Copenhagen) from the Kepplerites tychonis zone on Fossil Mountain, East Greenland; by the resemblance of $K$. cf. $K$. tychonis Ravn (Imlay, 1948, p. 16,25 , pl. 8, figs. $3,4,6$ ) to $K$. tychonis (Ravn) (Ravn, 1911, p. 490, pl. 37, fig. 1) from East Greenland; and by the occurrence of these ammonites in Montana below beds characterized by $K$. maclearni Imlay in association with Lilloettia and Xenocephalites (Imlay, 1953a, p. 8, $18,19,25$, pls. $1,15,16$, and part of 17 ). Such an association by comparison with ammonites of southern Alaska (Imlay, 1975, p. 6, 14) is definitely of early Callovian Age. In fact, with one exception, Xenocephalites in Alaska is not known above the basal part of the range of Lilloettia or Kepplerites.

In southern Alaska between Cook Inlet and the Wrangell Mountains the early to early middle Bathonian is probably represented by Cranocephalites, Arctocephalites, Parareineckeia, and Cobbanites (Imlay, 1962b, p. C20). The sequence containing these ammonites rests unconformably on beds of early late Bajocian Age and is overlain disconformably by beds of early Callovian Age (Imlay, 1962b, p. C2, C3; Detterman and Hartsock, 1966, p. 35, 40, 42). Arcticoceras has not yet been found in the sequence, but the time during which it lived could be represented locally near the top of the sequence or by the disconformity at the top.

In northeastern Alaska, the Bathonian is represented, in ascending order, by Cranocephalites spp., Arctocephalites cf. A. elegans Spath, and Arcticoceras ishmae (Keyserling) (Imlay and Detterman, 1973, p. 18, 24 , fig. 14). These fossils should represent most of the stage, because the ammonite sequence is similar to that in East Greenland (Callomon, 1959, p. 507, 508).

Concerning the age ranges of these genera in the arctic region, Spath (1932, p. 145) placed Arcticoceras in the Callovian and Arctocephalites in the Bathonian. Arkell $(1956$, p. 527) placed both genera as well as the somewhat older Cranocephalites in the Callovian. Callomon (1959), on the basis of field studies in East Greenland, assigned all three genera to the Bathonian and suggested that the earliest occurring species of Cranocephalites might be as old as latest Bajocian. He based these age assignments on the position of the Arcticoceras-bearing beds in East Greenland directly beneath beds that, according to him, contain a varied ammonite fauna closely similar to and in part identical with the fauna in the Macrocephalites macrocephalus zone of earliest Callovian Age in northwestern Europe. He discounted the presence of Cadoceras and Kepplerites at the top of the range of Arcticoceras, although both Cadoceras and Kepplerites are normally considered good evidence for a Callovian Age. Subsequently, Callomon (written commun., August 1972) determined that in Greenland the ranges of Cadoceras and Arcticoceras do not overlap but that Kepplerites does occur as low as the upper part of the range of Arcticoceras above Arcticoceras ishmae (Keyserling) (Callomon and others, 1972, p. 18, 19; Donovan, 1957; Surlyk and others, 1973).

In arctic Canada, the Bathonian is represented by an ammonite sequence that is nearly identical with that in 
Bathonian beds in East Greenland but that eontains different species of Cranocephalites from those known in northern Alaska. These differences probably reflect inadequate collecting.

\section{CALLOVIAN}

In Mexico, Callovian ammonites have been found in the south-central part (Guerrero embayment) and in the east-central part (Huayacocotla embayment) (Erben, 1957b, fig. 2). In the east-central part, the early Callovian is represented by Kepplerites (Cantú Chapa, 1969, p. 3) from a well core in Veracruz; the late early Callovian, by Neuqueniceras neogaeum and Reineckeia (Imlay, 1952a, p. 970; Erben, 1956b, p. 39; Cantú Chapa, 1971, p. 21) from the Necaxa area of Puebla; and the middle Callovian, by Erymnoceras ef. E. mixtecorum from slightly higher beds in the Necaxa area (Erben, 1957a, p. 47). In south-central Mexico (Oaxaca and Guerrero), the Callovian ammonite sequence is essentially the same, but also includes Peltoceras at the top, and Eurycephalites and Xenocephalites at the base.

The Callovian ammonite sequence in Mexico (see fig. 14) is similar to that in the Callovian of Chile (Hillebrandt, 1970, p. 176, 190, 202) and likewise includes taxa characteristic of the Pacific Realm, such as Xenocephalites, Eurycephalites, and Neuqueniceras. The presence of Xenocephalites and the close resemblance of Eurycephalites to Lilloettia (Hillebrandt, 1970, p. 202) show that the lower Callovian of Mexico contains some ammonites similar to those in the lower Callovian of Oregon, British Columbia, and southern Alaska.

Ammonites of Callovian Age have been found in the United States in southern and northeastern California, east-central Oregon, western Idaho, Alaska, and in the northern part of the western interior region.

A few ammonites found in Callovian beds in California are closely related to ammonites from Mexico and the Tethyan Realm. These California specimens include the early Callovian genera Macrocephalites and Hecticoceras from the Santa Ana Mountains in southern California (Imlay, 1963; 1964c, p. 508) and the late Callovian genus Peltoceras from the Sierra Nevada in east-central California (Imlay, 1961, p. 27, pl. 6). None of these have been found farther north in the Pacific Coast region.

Most of the Callovian ammonite faunas in the Pacific Coast region from British Columbia northward to Alaska are dominated by genera of the Boreal families Cardioceratidae and Kosmoceratidae, including Iniskinites, Cadoceras proper, Stenocadoceras, Paracadoceras, Pseudocadoceras, and Kepplerites (Imlay, 1953b, 1961, 1964a; Crickmay, 1930, 1933a, b; McLearn, 1929, 1949; Frebold and Tipper, 1967). Of these, only Iniskinites,
Pseudocadoceras, and Kepplerites are definitely identified south of British Columbia. The family Phylloceratidae is fairiy common throughout the region and is represented by several genera or subgenera that occur nearly worldwide. With these occur some genera of endemic or Pacific affinities, including Lilloettia, Xenocephalites, and Parareineckeia. In addition, a few ammonites present belong to the genera Oppelia, Grossouvria, Procerites, and Choffatia, all of which are nearly worldwide. The succession of genera and species is similar throughout the Pacific Coast region. Faunal evidence for beds of late Callovian Age is completely lacking north of east-central California, except for one occurrence in British Columbia (Frebold and Tipper, 1975, p. 149, 156).

In the western interior region, only the early and very latest Callovian is represented by ammonites (Frebold, 1957, p. 19-27; 1963; Imlay, 1953a). The early Callovian ammonites include Imlayoceras, Lilloettia, Xenocephalites, and Grossouvria and are dominated by the families Cardioceratidae, Macrocephalitidae, and Kosmoceratidae. Despite some generic resemblances with ammonites from the Pacific Coast region, there appear to be no species in common; the families Phylloceratidae and Lytoceratidae are unknown from the western interior, and the genus Imlayoceras Frebold (Frebold, 1963, p. 20) has been found only in that region.

The latest Callovian in the western interior region is represented by Quenstedtoceras (Lamberticeras) collieri Reeside from the Little Rocky Mountains and Bearpaw Mountains in north-central Montana. Recent collecting shows that it underlies and does not occur with Cardioceras as previously stated (Imlay, 1948, p. 16, 17).

In the arctic region of Alaska and Canada, the Callovian is represented by typical species of Cadoceras that are associated with $C$. (Stenocadoceras) and Phylloceras bakeri Imlay in the Richardson and British Mountains, Yukon Territory, Canada. This association, plus the absence of Kepplerites, favors correlation with the upper part of the Paveloff Siltstone Member of the Chinitna Formation in southern Alaska (Detterman and Hartsock, 1966, p. 48). That upper part is dated as middle to early late Callovian on the basis of the European range of $C$. (Stenocadoceras), the presence of $C$. (Longaeviceras?) pomeroyense (Imlay) near the top of the member, and the absence of Kepplerites in its upper half. Similarly, the Cadoceras-bearing beds in arctic Alaska and Canada are probably of middle Callovian Age because Kepplerites is unknown above the lower Callovian (Callomon, 1964 , p. 274, 275), Cadoceras proper is unknown above the middle Callovian (Callomon, 1955, p. 255; 1964, p. 273-278), and C. (Stenocadoceras) is unknown below the uppermost part of the lower Callovian (Arkell, 1956, p. 26). 


\section{OXFORDIAN}

In the subsurface of the southern United States, a few fragmentary ammonites of late Oxfordian Age have been found in the Smackover Formation (fig. 15). They include species of Perisphinctes (Dichotomosphinctes), $P$. (Discosphinctes), Euaspidoceras, and Ochetoceras (Imlay, 1945, p. 274, pl. 41, figs. 7-14), which appear to be identical with species from beds of late Oxfordian Age in Mexico (Burckhardt, 1912, p. 1-40, 203-312, pls. 17; Cantú Chapa, 1969, p. 6; 1971, p. 22, 37) and Cuba (Sánchez Roig, 1920, 1951; O’Connell, 1920; Jaworski, 1940; Judoley and Furrazola-Bermúdez, 1965, 1968, p. 5, $18,22)$. The late middle Oxfordian is probably represented at San Pedro del Gallo, Mexico, by the lower part of the Oxfordian sequence, which is below an upper part characterized by Ochetoceras canaliculatum (von Buch) and Discosphinctes carribbeanus (Jaworski). In the lower part, Dichotomosphinctes occurs in association with Taramelliceras (Proscaphites) (Burckhardt, 1912, p. 211, 212; Arkell, 1956, p. 563) and Creniceras cf. $C$. crenatum (Bruguière) (Burckhardt, 1912, p. 15, 16, pl. 7, figs. 15-17). Amoeboceras ef. A. alternans (von Buch) is reported by Burckhardt $(1930$, p. 66) from probable equivalent beds at another locality near San Pedro del Gallo. Early Oxfordian ammonites have not been found in the Gulf of Mexico region, except for unconfirmed reports of Creniceras renggeri (Oppel) at Huayacocotla in Veracruz, Mexico (Erben, 1957a, p. 47), and Fehlmannites at Xochapulco in Puebla, Mexico (Cantú Chapa, 1971, p. 23). Most of these ammonites in the Gulf region have Tethyan affinities.

In California and southwestern Oregon, as in the southern United States, the late Oxfordian is represented by species of Perisphinctes (Dichotomosphinctes) and $P$. (Discosphinctes) that are similar to species in Mexico and Cuba (Imlay, 1961, p. D7-D8, D10, D23-D25, pl. 3, figs. 1-10, pl. 4, figs. $4,7,8$ ). In west-central Idaho, the early Oxfordian is represented by Cardioceras (Scarburgiceras) martini Reeside (Imlay, 1964a, p. D15, pl. 2, figs. 1-5), which has Boreal affinities.

In the western interior of the United States, cardioceratid ammonites of early to early middle Oxfordian Age are fairly widespread, but ammonites of late Oxfordian Age have not been found (Reeside, 1919; Imlay, 1947, p. $264 ; 1948$, p. $16,17,25$, pl. 7 , figs. $12,14,15,18$; Arkell, 1956, p. 548). The presence of upper Oxfordian beds in northwestern Montana is shown, however, by the presence of Buchia concentrica (Sowerby) (Imlay, 1956a, p. 595). The oldest Oxfordian ammonites have been collected only in the lower part of the Swift Formation in north-central Montana, and belong to Quenstedtoceras (Pavloviceras), Prososphinctes, Cardioceras (Maltoniceras), and C. (Scarburgiceras). This assem- blage probably corresponds to the basal Oxfordian (zone of Quenstedtoceras mariae) of northwest Europe.

The next oldest ammonites of the marine lower Oxfordian have been found in north-central Montana directly above the beds containing an association of Cardioceras and Quenstedtoceras (Pavloviceras). They also occur at many other places in the western interior region. These ammonites apparently represent a single faunal zone (Cardioceras cordiforme), although by European standards they probably correspond to the zones of Cardioceras cordatum and Perisphinctes plicatilis. They are closely related specifically to ammonites in British Columbia, Alaska, and the arctic region, but have nothing in common generically with Oxfordian ammonites in the Gulf of Mexico region.

In Alaska, both the early and the late Oxfordian are represented mostly by genera of the Cardioceratidae. Cardioceras is the most common genus in the lower Oxfordian, as is Amoeboceras in the upper Oxfordian. In the basal part of the Cardioceras-bearing beds, the subgenus Scarburgiceras is locally common. Perisphinctes (Dichotomosphinctes) is associated with Buchia concentrica (Sowerby), of late Oxfordian to early Kimmeridgian Age on the Alaska Peninsula (Imlay, 1961, p. D11, pl. 4, fig. 6). The presence of Phylloceras and $L y$ toceras in fair abundance contrasts with their complete absence in Oxfordian beds in the western interior of the United States.

The Oxfordian ammonite sequences in western and arctic Canada are nearly the same as those in Alaska (Frebold, 1961, p. 22-24, 29, 30, table 1 opposite p. 26; 1964a, p. 4; Frebold and Tipper, 1970, p. 13, 14, 17; Frebold and others, 1959). Likewise, few ammonite taxa are present, and an exact faunal boundary between Oxfordian and Kimmeridgian cannot be drawn.

\section{KIMMERIDGIAN}

The Kimmeridgian Stage as used herein follows the recommendation of Enay and others (1971, p. 97). It is equivalent to the lower Kimmeridgian of Arkell (1956, p. $21,22)$ and to the lower part of the Kimmeridge Clay of England below the ammonite zone of Pectinatites (Virgatosphinctoides) elegans (Cope, 1967, p. 66).

In eastern Mexico, the Kimmeridgian ammonite sequence from the base up, according to Cantú Chapa (1971, p. 25, 26, 36), is characterized by (1) Ataxioceras associated with Rasenia, (2) Idoceras, and (3) the Glochiceras group of $G$. fialar. In northern Mexico, the sequence recognized by Burckhardt $(1930$, p. $64,66,91,92)$ is nearly the same, except for the presence of Sutneria cf. S. platynota (Reinecke) at the base. Also, in the lower part of the bed containing Glochiceras ef. G. fialar are species of "Aucella" (Burckhardt, 1906, p. 144, 155; 
1912 , p. $50,67,80)$ that are now referred to as Buchia concentrica (Sowerby) and B. mosquensis (von Buch) (Imlay, 1955, p. 85).

This faunal sequence was modified slightly by Imlay $(1939$, p. 21 , tables 4,$5 ; 1943 \mathrm{a}$, p. 1471) because of an apparent association of the Idoceras group of $I$. durangense Burckhardt with Glochiceras cf. G. fialar at some localities. Still later, studies by Cantú Chapa (1970, p. $42 ; 1971$, p. 26), dealing with both subsurface cores and outcrops, showed that Idoceras invariably occurs in a lower bed than does Glochiceras ef. G. fialar.

A few ammonites of Kimmeridgian Age have been found in the southern United States (figure 15) in the subsurface of northwestern Louisiana (Imlay, 1945, p. 271-274, pl. 41, figs. 15-28) and east Texas and in outcrops in west Texas (Cragin, 1905; Albritton, 1937; 1938, p. 1761-1764). Well cores in Louisiana have yielded species of Idoceras, Ataxioceras, Metahaploceras, and Glochiceras that appear to be identical with species from beds of early and middle Kimmeridgian Age in Mexico (Imlay, 1943a, p. 1471-1472); Burckhardt, 1906, p. 2106). From the Malone Mountains in west Texas, early Kimmeridgian ammonites have been obtained that belong to the genera Haploceras, Idoceras, Nebrodites, Physodoceras, and Aspidoceras. Some of these are identical specifically with ammonites from beds of Kimmeridgian Age in northern Mexico. The ammonite species and genera of Kimmeridgian Age that have been found in the southern United States are only a small part of the assemblages of Kimmeridgian Age that are known in Mexico (see Burckhardt, 1930, p. 66-68; Imlay, 1939, tables $4-6,10)$.

In California, the lower to middle Kimmeridgian has been identified faunally. This identification in California is based on an abundance of the pelecypod Buchia concentrica (Sowerby) in association with the boreal ammonite Amoeboceras (Amoebites) and the nonboreal ammonites Subdichotomoceras? and Idoceras (Imlay, 1961, p. D8, D22, D25, D26; pl. 2, figs. 24-28; pl. 5, figs. 1-3, $9,12-16)$.

In northwest Sonora, on Rancho Cerro Pozo Serna, the Kimmeridgian is represented by an association of Idoceras, Amoeboceras, and Aulacomyella (T. E. Stump, Univ. Calif. at Davis, written commun., Apr. 1973). Of these ammonites, Idoceras ranges through about 565 feet of beds; Amoeboceras occurs in the lower 510 feet of that range; and Aulacomyella is associated with the highest occurrence of Amoeboceras. Aulacomyella occurs elsewhere in Mexico in beds characterized by $I d o-$ ceras and Glochiceras cf. G. fialar (Burckhardt, 1930, p. 51, 67, 86, 90, 92, 96, 97; Imlay, 1940a, p. 399; 1943a, p. 1472) but ranges higher into beds containing the lowest occurrences of Virgatosphinctes (Cantú Chapa, 1971, p. 27, 28, 36). The occurrence of Amoeboceras with Ido- ceras in Sonora is considerably younger than its reported occurrence with Dichotomosphinctes durangensis Burckhardt near San Pedro del Gallo, Durango (Burckhardt, 1930, p. 66).

Marine Kimmeridgian beds have not been identified in the western interior of the United States or east of the Canadian Rocky Mountains. Throughout western and arctic Canada and Alaska, the identification of beds of Kimmeridgian Age is based mostly on the ranges of species of Buchia (Imlay, 1955, p. 83-86), because ammonites of definite Kimmeridgian Age have not been found. Some of the specimens of Amoeboceras from Alaska (Reeside, 1919, p. 30 , pl. 18, fig. 4, pl. 19, figs. 1-3; Imlay, 1955 , p. 90 , pl. 12, figs. 2-6) could be of early Kimmeridgian Age, but their resemblance to the subgenus Prionodoceras favors a late Oxfordian Age, judging by the range of that subgenus in northwest Europe (Arkell and others, 1957, p. L307).

\section{TITHONIAN}

\section{DEFINITION AND CORRELATIONS}

The Tithonian Stage is now defined (Enay, 1964, 1971) so that it correlates at its base with the Volgian Stage of the Boreal Realm (Saks and Shulgina, 1964; Saks and others, 1968 and 1972; Gerasimov and Mikhailov, 1967) (equals North Temperate Realm of Kauffman, 1973, p. 367). This correlation is based primarily on the local association in Europe of the subboreal ammonite Gravesia with the Tethyan ammonite Hybonoticeras, which is widespread in southern Europe, Madagascar, India, and Mexico (Enay, 1972, p. 370; Zeiss, 1968, p. 137, 143-146).

The Tithonian is commonly divided into three parts, on the basis of the stratigraphic ranges and associations of certain ammonites (fig. 16). As thus divided, the lower Tithonian is equivalent to the middle and part of the upper Kimmeridgian of England as defined by Arkell (1956, p. 21) and to most of the upper Kimmeridgian as redefined by Cope (1967, p. 4, 70, 74). The middle Tithonian as defined by Enay in 1964 (p. 365) is equivalent to the remainder of the Kimmeridgian of England plus an indefinite part of the Portlandian. The middle Tithonian as defined by Zeiss (1968, p. 137) includes only the zones of Pavlovia rotunda and $P$. pallasioides of northwest Europe. As redefined by Enay (1971, p. 99, 100), it includes those zones plus part of the underlying zone of Pectinatites pectinatus; it does not include any faunal zone as young as the Portlandian. The middle Tithonian as used by Judoley and Furrazola-Bermúdez (1968, p. 5) and by Imlay and Jones (1970, p. B8-B9) is nearly the same as that used by Enay in 1964. The upper Tithonian of these 
various authors includes all Jurassic beds above the middle Tithonian.

The Tithonian has also been divided into two parts by Enay $(1964$, p. 363,$364 ; 1971$, p. 99, 100) who considers a threefold division impractical except in those areas where Pseudolissoceras and Semiformiceras are present (Enay, 1972, p. 371). Also, the association of Pseudolissoceras with the typical late Tithonian ammonite Proniceras in Kurdistan (Spath, 1950, p. 125) suggests that Pseudolissoceras may range higher than recorded in $\mathrm{Eu}-$ rope. Therefore, a twofold division is favored by Enay (1971, p. 99; 1972, p. 382), who has correlated the lower Tithonian with the upper part of the Kimmeridge Clay of England above the zone of Aulacostephanoceras acutissiodorensis (Cope, 1967, p. 4, 70). He correlated the upper Tithonian with the remainder of the overlying Jurassic above the zone of Pavlovia pallasioides. As thus defined, the base of the upper Tithonian corresponds to the first appearance of the calpionellid microfossils and to the first appearance of such ammonites as Kossmatia, Durangites, Corongoceras, Micracanthoceras, Lytohoplites, and Hildoglochiceras.

A threefold faunal division of the Tithonian within the Gulf region is feasible and useful, as discussed by Cantú Chapa (1967, p. 18-22, table 1; 1971, p. 27-31), but there is no assurance that the middle part is even approximately the same as the middle Tithonian as used in Eurasia. For correlations between the continents, preference is given herein to a twofold division of the Tithonian because the faunal boundary between the two divisions is much sharper than are the boundaries within the threefold division.

\section{LOWER TITHONIAN OF THE GULF REGION}

In the Gulf of Mexico and bordering areas, early Tithonian fossil sequences are well known only in northern, north-central, and eastern Mexico (fig. 15). In north-central Mexico near Mazapil, Zacatecas, the early Tithonian ammonite sequence from the base upwards apparently consists of (1) Hybonoticeras ( = Waagenia); (2) Mazapilites in association with Virgatosphinctes aguilari (Burckhardt), V. spp., Subdichotomoceras cf. S. nikitini (Michalski), Aulacosphinctoides and Aspidoceras; and (3) Virgatosphinctes mexicanus Burckhardt, V. spp., Subplanites cf. S. danubiensis (Schlosser), Parastreblites mazapilensis (Burckhardt) and Pseudolissoceras subrasile Burckhardt (Burckhardt, 1906, p. 110, 147149 ; 1930 , p. $68-71$, tables 6-9; Imlay, 1939 , p. 27-30, 38,39 , tables $7-10$ ). Of these, only the relative positions of Mazapilites and Virgatosphinctes mexicanus are questionable, because those taxa have not yet been collected in the same stratigraphic sequence in central or northern Mexico. At first, Burckhardt (1906, p. 168 170) considered them to be of the same age because they both occur in similar phosphatic limestone in areas near Mazapil. Later, he decided that Mazapilites must be older because near Symon, Durango, about 70 miles (112 $\mathrm{km}$ ) west of Mazapil, the lowest occurrence of Mazapilites is in the same bed with Hybonoticeras (Burckhardt, 1919 , p. $74 ; 1930$, p. 56). This association was confirmed by Imlay $(1939$, p. 10,11$)$.

The early Tithonian ammonite sequence near Symon, Durango (Burckhardt, 1919 , p. $61-66 ; 1930$, p. 56 , $57,68,69$; Imlay, 1939, p. 9-11), resembles that near Mazapil except that its upper part above Mazapilites contains only rare specimens of Subplanites? (Blanchet, 1923, p. 74; Burckhardt, 1919, p. 39; 1921, pl. 14, figs. 13) and Virgatosphinctes? (Imlay, 1939, p. 10). Also, all the beds above Hybonoticeras and below Kossmatia contain an abundance of ammonites that generally have been assigned to Torquatisphinctes rather than to Aulacosphinctoides (Spath, 1931, p. 466, 484, 1933, 865; Imlay, 1939, p. 22, table 7; Arkell, 1956, p. 562; Enay, 1972, p. $382)$.

Mazapilites has been found elsewhere in north-central Mexico only in the Sierra de Catorce, northern San Luis Potosí, about 75 miles $(120 \mathrm{~km})$ southeast of Mazapil. In this mountain, the early Tithonian is represented only by one ammonite assemblage consisting of Phylloceras, Virgatosphinctes (rare), Aulacosphinctoides, Subdichotomoceras, Andiceras, Aspidoceras, Simoceras, Haploceras, Pseudolissoceras zitteli (Burckhardt), and Mazapilites (rare). Most of these occur in 10 feet $(3 \mathrm{~m})$ of limestone (Verma and Westermann, 1973, p. 148) and do not occur in the higher (early late Tithonian) assemblage characterized by Kossmatia and Durangites. Mazapilites itself was obtained from just 2 feet $(0.6 \mathrm{~m})$ of limestone at only one place, in association with Pseudolissoceras zitteli, Aulacosphinctoides, Subdichotomoceras, and "Virgatosphinctes" sanchezi Verma and Westermann (Verma and Westermann, 1973, loc. 23B on p. 141, $148,186)$. The last named species was described as similar to Subplanites? sp. in Imlay (1939, p. 36, pl. 9, figs. $1-3)$. Burckhardt (1919, p. 39; 1921, p. 14, figs. 1-3) found it similar to Virgatites sp. ind., which was renamed Perisphinctes burckhardti by Blanchet $(1923$, p. 74$)$ and referred questionably to as Subplanites by Arkell (1956, p. 562).

Another early Tithonian ammonite sequence occurs near Placer de Guadalupe and Plomosas in east-central Chihuahua, about 450 miles $(700 \mathrm{~km})$ north-northwest of the one at Mazapil (Bridges, 1965, p. 66-77, 105, 118120, 132-134; Imlay, 1943b). The oldest Tithonian is represented by Hybonoticeras (=Waagenia) (Imlay, $1943 \mathrm{~b}$, p. 527-529), which was found about 15 miles (24 
$\mathrm{km})$ south-southeast of Placer de Guadalupe. The remainder of the early Tithonian ammonite sequence is well exposed in a fairly thick section (Bridges, 1965, fig. 15 on p. 76, p. 133-134) that was measured northeastward, starting from a point about 1.2 miles $(2 \mathrm{~km}) \mathrm{N} .42^{\circ}$ E. of Placer de Guadalupe.

In that section, some conglomerates that are probably Paleozoic are overlain by shale 152 feet $(46 \mathrm{~m})$ thick that contains Idoceras from $66-100$ feet $(20-30 \mathrm{~m})$ above its base, and Idoceras? throughout its lower 126 feet $(38 \mathrm{~m})$. Above this shale is about 160 feet $(49 \mathrm{~m})$ of unfossiliferous sandstone. Next higher is 1,075 feet (328 $\mathrm{m})$ of dark shale and shaly limestone that contains species of Virgatosphinctes, Subplanites, and Pseudolissoceras, which are like those found with $V$. mexicanus in southern Zacatecas, in 3-6 feet (1-2 m) of limestone. Above the dark shale and limestone is 565 feet $(172 \mathrm{~m})$ of shale that contains Virgatosphinctes ef. $V$. densiplicatus (Waagen). At the top of the section is 465 feet $(142 \mathrm{~m})$ of shale and sandstone that contains Kossmatia. Mazapilites has not been found in the sequence, but the time during which it lived could be represented by any one of several 50 - to 60 -foot (15- to $18-\mathrm{m}$ ) units that have not furnished any ammonites.

The lowest of these faunules is definitely of early Tithonian Age, judging by an association of Subplanites, Virgatosphinctes and questionable Pseudolissoceras (Arkell and others, 1957, p. 329, 330; Bridges, 1965, pl. 3 on p. 76). It may be correlated with a faunule near Mazapil that is characterized by Virgatosphinctes mexicanus Burckhardt, Pseudolissoceras subrasile (Burckhardt), and Subplanites (Burckhardt, 1906, p. 155, 156; 1930, p. 69). Thus, Subplanites aff. S. reise (Schneid) (Imlay, 1943b, p. 533, pl. 91, fig. 1) from Chihuahua is probably identical with Perisphinctes ef $P$. danubiensis (Schlosser) in Burckhardt (1906, p. 112, pl. 32, fig. 1) and Virgatosphinctes chihuahuensis Imlay (Imlay, 1943b, p. 534, pl. 91, figs. 2-5) is probably the same as Perisphinctes aff. P. transitorius Oppel in Burckhardt (1906, p. 113 , pl. 30 , fig. 8 ).

Above this lowest faunule is a finely ribbed species of Virgatosphinctes (Imlay, 1943b, p. 535, pl. 89, figs. 1-4), whose resemblance to $V$. densiplicatus (Waagen) suggests correlation with the basal upper Tithonian (Enay, 1972, p. 377, 378). Still higher are species of Kossmatia that represent the lower part of the upper Tithonian of Enay.

A much different early Tithonian ammonite sequence is present in the Huasteca area of east-central Mexico, according to Cantú Chapa (1971, p. 24-30, 33, 36, 38), whose conclusions are based on both surface and subsurface studies. That sequence is distinguished from all those just discussed by the local absence or scarcity of
Hybonoticeras at the base of Tithonian and by the presence of Mazapilites above instead of below Virgatosphinctes mexicanus (Burckhardt).

Of these differences, the rarity of Hybonoticeras is probably related to sparse occurrences in very thin beds, as suggested by Cantú Chapa (1971, p. 28). Hybonoticeras is present, however, at two localities in eastern Mexico. One specimen was obtained at the base of the Corona-San Manuel well 82 , about 30 miles $(48 \mathrm{~km})$ southwest of Tampico, Tamaulipas (USGS Mesozoic loc. 20854). Another was found in chalky limestone in Arroyo La Mula at the west end of the Huizachal anticline, west of Victoria, Tamaulipas (USGS Mesozoic loc. 20836). The occurrence of Mazapilites above Virgatosphinctes mexicanus in eastern Mexico but below it elsewhere could be explained if one or both of those taxa had longer or different stratigraphic ranges than those shown by studies in north-central Mexico, or if the Mazapilitesbearing beds in eastern Mexico were separated from overlying Kossmatia-bearing beds by a disconformity, or by a nonsequence, reflecting lack of deposition.

In summation, the biostratigraphic record, as discussed above, shows that Virgatosphinctes in northern and north-central Mexico ranges through the lower Tithonian above the beds containing Hybonoticeras. Locally, in north-central Mexico near Mazapil, species of Virgatosphinctes occur in two faunules, of which only the lowest contains Mazapilites and only the highest contains Pseudolioceras. The higher faunule is represented elsewhere in northern Mexico near Symon, Durango, and in east-central Chihuahua by identical or closely similar species of Virgatosphinctes and Subplanites. Against such a faunal division is the association of Mazapilites with Pseudolissoceras in the Sierra de Catorce of San Luis Potosí. That association may not be of stratigraphic value, however, if the 2 teet $(0.6 \mathrm{~m})$ of limestone in which the ammonites occur represents a condensed deposit that formed so slowly that organisms of different ages occur together. Much better evidence against the faunal division recorded for north-central Mexico is the presence of Mazapilites above Virgatosphinctes mexicanus in eastcentral Mexico. Evidently, more stratigraphic collecting is needed in order to determine the total range of $\mathrm{Maza}$ pilites and the correct ammonite succession in the lower Tithonian beds of Mexico. Nonetheless, the range of $\mathbf{M a}$ zapilites into the middle part of the lower Tithonian is favored by its association with Pseudolissoceras and Protancyloceras in Cuba below beds containing Torquatisphinctes and Parapallasiceras (Housa and de La Nuez, 1975).

Elsewhere in the Gulf region, lower Tithonian beds may be represented in Cuba by an association of Virgatosphinctes and Subplanites? beneath beds containing 
typical upper Tithonian ammonites such as Durangites, Corongoceras, and Micracanthoceras (Judoley and Furrazola-Bermúdez, 1968, p. 5, 19, 23, 109-111). The lower Tithonian assignment is based on two facts: Virgatosphinctes is unknown from beds older than the Tithonian (Arkell and others, 1957, p. L330), and Subplanites is characteristic of the entire lower Tithonian (Enay, 1964 , p. $365 ; 1971$, p. 99,$100 ; 1972$, p. 382). One trouble with this correlation is that the species of Subplanites? and Virgatosphinctes in question are reported by Judoley and Furrazola-Bermúdez $(1968$, p. 19) to be associated with Tintinids as well as with the ammonite Parodontoceras butti Imlay, which are not known below the upper Tithonian.

\section{UPPER TITHONIAN OF THE GULF REGION}

\section{AMMONITE SEQUENCES}

Upper Tithonian ammonite sequences are well known in lands bordering the Gulf of Mexico (Burckhardt, 1906, p. $125-141,148,149,170,171 ; 1912$, p. 127-172, 220226; 1930, p. 70, 71, tables 6, 8, 9; Imlay, 1939, p. 23, 24, tables 8-10; 1942; Cantú Chapa, 1963, p. 27-29, 33, $37-41,70 ; 1967 ; 1968 ; 1971$, p. $28-31,37-39$ ). They are divisible into two assemblages, of which the lower is characterized by Kossmatia, Durangites, Lytohoplites, Simoceras, Metahaploceras, Dickersonia, and Pseudolissoceras. The upper assemblage is characterized by Berriasella, Substeueroceras, Aulacosphinctes, Protacanthodiscus, Proniceras, and rarely Himalayites. With both assemblages occur Parodontoceras, Hildoglochiceras, Micracanthoceras, and Corongoceras. Virgatosphinctes occurs rarely in the lower assemblage in Cuba and in the upper assemblage in Mexico.

The ages of these ammonite assemblages have been discussed sufficiently elsewhere (Cantú Chapa, 1967, p. 17-22; 1971, p. 30, 31; Imlay and Jones, 1970 , p. B11B12; Enay, 1972, p. 361, 371, 376, 382). Substeueroceras and Proniceras must represent the latest Tithonian. Kossmatia and Durangites must represent slightly older Tithonian, but their exact ranges relative to the standard zones of Europe are difficult to determine. Nonetheless, the presence of calpionellid microfossils in the Kossmatia-bearing beds indicates an age not older than late Tithonian as defined by Enay (1971, p. 99). Also, the presence of Buchia mosquensis (von Buch) locally in those beds at San Pedro del Gallo, Durango (Burckhardt, 1912, p. 206, 221) shows that some of those beds are at least as old as the Zaraiskites albani zone of northwest Europe and the equivalent upper part of the Dorsoplanites panderi zone in Russia (Imlay, 1955, p. 74, 75, 85; 1959b, p. 157; Imlay and Jones, 1970, p. B11; Gerasimov and Mikhailov, 1967, p. 9, 19, 20; Saks and others, 1963, table 5).

Both of these assemblages are associated with calpionellid microfossils of late Tithonian Age. Such microfossils occur with the higher assemblage characterized by Substeueroceras in Puebla, Mexico (Cantú Chapa, 1967, table 1 opposite p. 22) and also throughout the lower assemblage in Cuba (Bronnimann, 1954; Bermúdez, 1961; Judoley and Furrazola-Bermúdez, 1968, p. 14-19). In Mexico, they are reported from La Casita and Pimienta Formations (Bonet, 1956, p. 417-419, 462, 463, 468, table opposite p. 398), and they occur also in the Sierra Cruillas, Tamaulipas (Bonet, 1956, localities 44, 45, and 48 on p. 468), just below a sequence containing Kossmatia and Durangites.

\section{KOSSMATIA-DURANGITES AMMONITE ASSEMBLAGE}

The lowermost upper Tithonian ammonite assemblage in Cuba is dated confidently as Late Jurassic, but not the very latest, for reasons that have been discussed in detail elsewhere (Imlay, 1942, p. 1433, 1434; Arkell, 1956, p. 572; Judoley and Furrazola-Bermúdez, 1968, p. 24, 25). It is rather peculiar, however, that Protancyloceras, with is common in the assemblage in Cuba, is unknown in Mexico below the uppermost upper Tithonian. It is also peculiar that Protancyloceras has not been found in Cuba in association with Durangites (Imlay, 1942 , p. 1428), an ammonite characteristic of the lowermost upper Tithonian in Mexico. These peculiarities are probably unimportant stratigraphically because Protancyloceras hondense Imlay (written commun. to Paul Bronniman, March 1953) occurs on Loma Sabinilla, Las Villas Province (Gulf Oil Co. locs. 21141 and 21142), at about the same place where Durangites was collected (Atlantic Refinery Co. locs. 268, 269, and 7539), and below the lowermost occurrences of calpionellas (Paul Bronniman, written commun., 1953). Also, Protancyloceras has been recorded in central Europe and in Kurdistan in beds that are slightly older than latest Tithonian (Wiedmann, 1973, p. 309, 310, 313, 314).

Durangites vulgaris Burckhardt in Cuba, in addition to the occurrences in Camagüey and Las Villas Provinces previously listed (Imlay, 1942, p. 1428, 1453), occurs at Finca Ancon, 3 miles $(5 \mathrm{~km})$ west of Balneario San Vicente in Pinar del Rio Province (Gulf Oil Co. loc. 24976). It is associated there with $D$. cf. $D$. incertus Burckhardt, Hildoglochiceras? ecarinatum Imlay, and an ammonite fragment whose venter bears chevron-shaped ribs, as would Kossmatia or Proniceras. That species of Hildoglochiceras? or Glochiceras (Cantú Chapa, 1968, p. 20) occurs elsewhere in association with Durangites (Imlay, 1939, p. 5, 28). 
The earliest late Tithonian assemblage, present in the subsurface of eastern Mexico and in the mountains and plateau to the west, contains many species in common with Cuba (Imlay, 1942, p. 1428, 1432). This is well illustrated by the ammonites present in the upper 394 feet $(120 \mathrm{~m})$ of a 722 -foot-thick (220-m) Jurassic sequence exposed on the Sierra Cruillas, southwest of Cruillas, in north-central Tamaulipas. That fossiliferous part of the sequence from top to bottom is as follows:

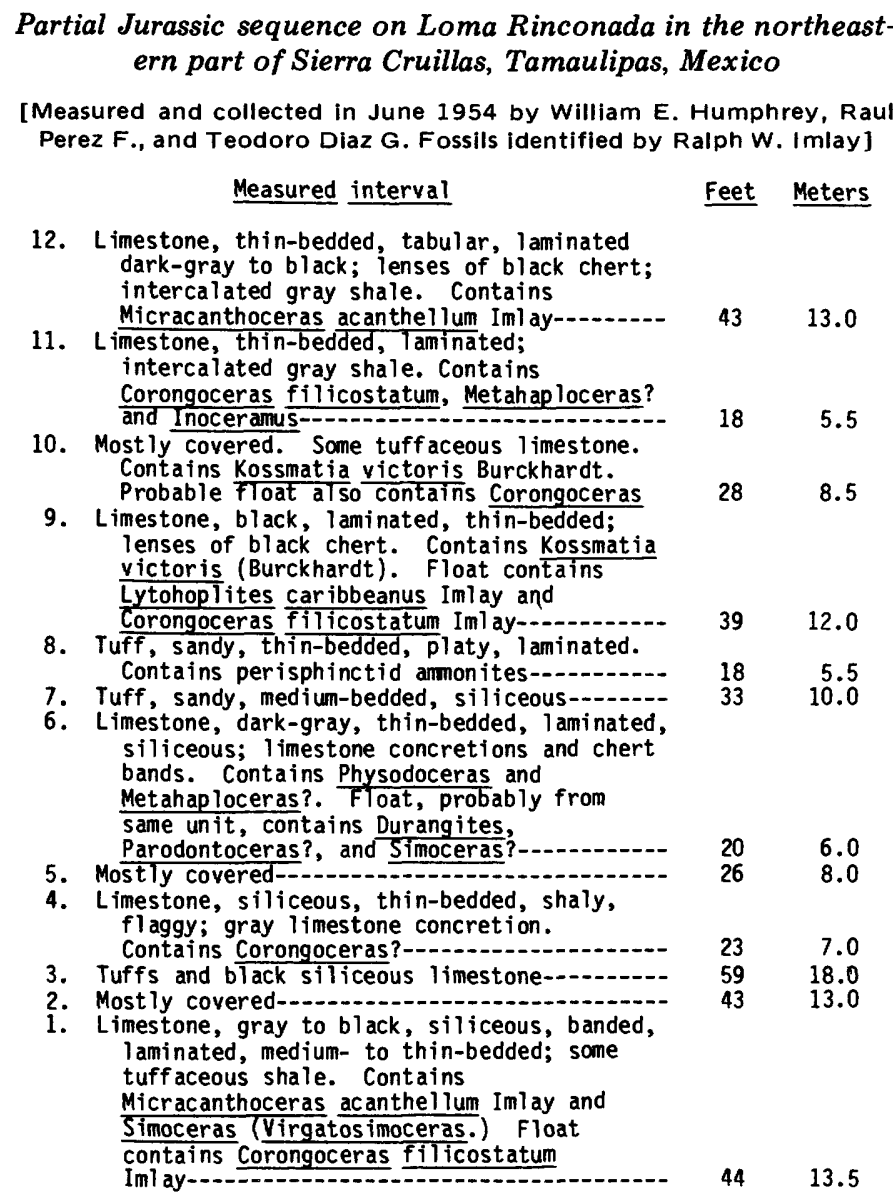

Other Mexican ammonites of the earliest late Tithonian assemblage that are similar to species in Cuba, or that are of stratigraphic significance, include the following:

1. Parodontoceras ef. $P$. butti Imlay. Petroleos Mexicanos lot 20851 from the Pimienta Formation $3 \mathrm{~km}$ south of Jonotla on trail to Zacapoaxtla, Puebla (written commun. to M. R. Aguilar, 1948).

2. Dickersonia cf. D. sabanillensis Imlay. Chocoy well 2 at depth of 3,195 feet $(974 \mathrm{~m})$, about 28 miles $(45 \mathrm{~km})$ northwest of Tampico, Tamaulipas. Associated ammonites include Parodontoceras and
Corongoceras cf. C. alternans Gerth (written commun. to Federico Bonet, 1959).

3. Pseudolissoceras zitteli (Burckhardt) in association with Kossmatia victoris (Burckhardt) and Grayiceras? mexicanum (Burckhardt), Mazatepec area, Puebla (Cantú Chapa, 1967, p. 4, 5, 21; 1971, p. 30).

4. Proniceras sp. associated with Durangites, Parodontoceras and Micracanthoceras. Petroleos Mexicanos lot AC-1933 from Bolson de Judas in Candela district near boundary of Coahuila and Nuevo Leon (written commun. to Teodoro DíazGonzalez, 1953).

The mentioned association of Proniceras with Durangites, as well as a similar association reported by Cantú Chapa (1968, p. 23-25) from Galeana in southern Nuevo Leon, could mean either that Durangites ranges up into the uppermost Tithonian or that Proniceras occurs lower than previously recorded.

The earliest late Tithonian ammonite assemblage of north-central Mexico is dominated by species of Kossmatia and Durangites (Burckhardt, 1930, p. 70, 71) but also includes Micracanthoceras, Hildoglochiceras ( = Salinites Cantú Chapa, 1968, p. 20), Grayiceras?, Aulacosphinctes?, and Micracanthoceras (Imlay, 1939, p. 22, table 8). This lower faunule near Placer de Guadalupe in east-central Chihuahua is represented mainly by species of Kossmatia near the top of the Jurassic sequence. Of the species present, $K$. kingi Imlay is probably identical with Perisphinctes sp. ind. in Burckhardt (1906, p. 130, pl. 37, figs. 9, 11, 12), and $K$. varicostata Imlay is closely similar to K. victoris Burckhardt (Burckhardt, 1906, p. 131, pl. 26, figs. 1-6, pl. 27, fig. 1).

An associated species, Kossmatia rancheriasensis Imlay, has been found elsewhere, in the Malone Mountains of Texas. R. T. Hazzard collected the species about 25 feet $(7.6 \mathrm{~m})$ below a conglomerate at the base of the Lower Cretaceous(?) Torcer Formation, approximately three-quarters of a mile $(1.2 \mathrm{~km})$ northwest of a cafe at a bend on U.S. Highway 80,10 miles $(16 \mathrm{~km})$ west of Sierra Blanca, Tex. (USGS Mesozoic loc. 26956). Another fragment of Kossmatia found in the conglomerate (Albritton, 1937, pl. 4, fig. 1) was probably derived from the underlying Malone Formation.

\section{SUBSTEUEROCERAS-PRONICERAS AMMONITE ASSEMBLAGE}

The latest late Tithonian ammonite assemblage in the Gulf region, characterized by Substeueroceras and Proniceras, is not known in Cuba. It is represented in the subsurface of the southeastern United States only by one occurrence of Substeueroceras at the depth of 17,403 feet $(5,304 \mathrm{~m})$ in the Humble Benavides well 1 in Webb 
County, Tex. It is widespread in eastern and north-central Mexico in both the surface and subsurface, and is not represented in Chihuahua or in west Texas.

In southeastern Mexico (Huasteca area), two faunal units, or zones in the uppermost upper Tithonian are recognized by Cantú Chapa (1967, p. 22, table 1). Of these, the higher faunal unit is characterized by Parodontoceras cf. $P$. callistoides (Behrendsen) in association with Proniceras and Protacanthodiscus. The lower faunal unit is characterized by Suarites bituberculatum Cantú Chapa in association with the genera Acevedites, Wichmanniceras, and Corongoceras (Cantú Chapa, 1967, p. 12-14, 18-20) and occurs below the lowest known occurrences of calpionellid microfossils.

Probably the most complete latest Jurassic ammonite sequence found in the subsurface in Mexico occurs at depths of 10,505 to 10,761 feet $(3,202$ to $3,280 \mathrm{~m})$ in the San Javier well 1, Nuevo Leon (see location in Pérez Fernández and Díaz-Gonzales, 1964, p. 232); it is described as follows:

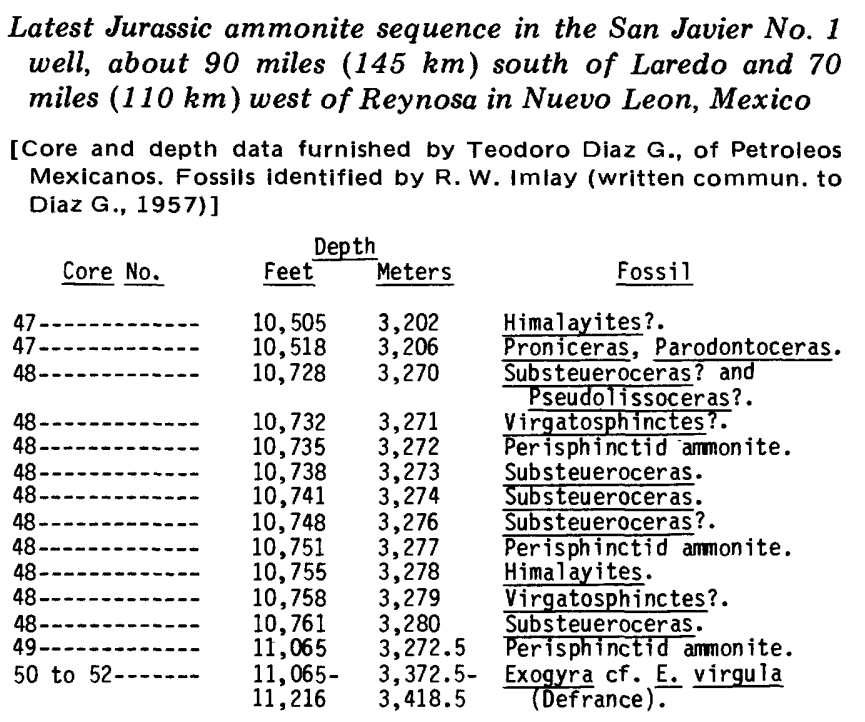

In this well, the contact with the Cretaceous is not indicated by megafossils, but cores from depths of 10,028 to 10,064 feet $(3,056.5$ to $3,067.5 \mathrm{~m})$ contain the ammonites Olcostephanus, Bochianites, Thurmanniceras, Sarasinella, and Kilianella of Valanginian to early Hauterivian Age.

Occurrences of most of the latest Jurassic ammonite genera in Mexico are well documented. Occurrences of the uncoiled ammonite, Protancyloceras, are listed below, however, because the presence of the genus in Mexico was not recognized until recent years, and because some species are similar to or identical with species in Cuba (Imlay, 1942, p. 1456, 1457, pl. 10, fig. 1 to 9, 11, 12).
1. Protancyloceras cf. $P$. hondense Imlay. Tantima well 2 at depths of 8,036 to 8,045 feet $(2,449$ to 2,452 m), near Tantima, Veracruz. Associated with Substeueroceras and Parodontoceras (written commun. to M. R. Aguilar, 1953).

2. Protancyloceras cf. $P$. catalinense Imlay. Piedra de Cal well No. 8 at depths of 5,837 to 5,850 feet $(1,779$ to $1,783 \mathrm{~m})$, about 60 miles $(100 \mathrm{~km})$ southwest of Tampico, near Tantoyuca, Veracruz. Associated with Substeueroceras (written commun. to Federico Bonet, 1959).

3. Protancyloceras anahuacense Cantú Chapa (1963, p. 28, 73, pl. 1, figs. 2-4) from the Anahuac well 1 at depths of $8,200-8,213$ feet $(2,499.3$ 2,503.3 m), near Anahuac in northern Nuevo Leon (Pérez Fernández and Díaz Gonzales, 1964, p. 232). Associated with Proniceras, Substeueroceras? and Protacanthodiscus.

4. Protancyloceras barrancense Cantú Chapa (Cantú Chapa, 1963, p. 27, 73, pl. 1, fig. 5) from the Barranca 1 well at depths of 8,755 to 8,768 feet $(2,668.5$ to $2,672.5 \mathrm{~m})$, Panuco-Ebano area, Veracruz.

5. Protancyloceras alamense Cantú Chapa (Cantú Chapa, 1963, p. 28) for Aegocrioceras sp., in Imlay (1939, p. 5, 57, pl. 11, figs. 1, 2) from Cañon Alamo, Sierra Jimulco, Coahuila. Associated with Proniceras, Aulacosphinctes, Hildoglochiceras, Micracanthoceras, Parodontoceras, and Substeueroceras.

6. Protancyloceras ramirense Cantú Chapa (Cantú Chapa, 1963, p. 28) for Crioceras sp. incl. in Burckhardt (1919, p. 58, 69; 1921, pl. 21, fig. 3) from near the Jurassic-Cretaceous contact in the Sierra Ramirez, near Symon, Durango. Associated with Parodontoceras (Burckhardt, 1921, pl. 20, figs. 1-3) and Substeueroceras.

\section{TITHONIAN OF CALIFORNIA AND OREGON}

In western California and southwestern Oregon, the upper Tithonian contains a sequence of ammonites similar to those present in the Gulf region (Imlay and Jones, 1970 , p. B6-B12). These are associated with species of Buchia that permit correlations with faunas to the north in Canada and Alaska. As Buchia mosquensis (von Buch) had not been found in California or Oregon, it is assumed that the base of the Kossmatia-bearing beds in those States is not as old as the base of the Kossmatia-bearing beds in Mexico (Imlay and Jones, 1970, p. B11).

\section{TITHONIAN OF CANADA AND ALASKA}

Tithonian beds are widespread in western and arctic Canada and in southern and northern Alaska, judging 
from occurrences of certain species of Buchia that furnish correlations with those in Greenland and northern Eurasia (Jeletzky, 1965, p. 57; Imlay, 1965, p. 1034; Imlay and Jones, 1970, p. B8, 9, 19; Frebold and Tipper, 1970 , p. 17). Associated ammonites are rare and are generally poorly preserved (Frebold, 1957, p. 35, 66, pls. 42-44; Frebold, 1961, p. 23, pl. 17, fig. 2; Jeletzky, 1966, p. 3-23, pls. 1-5, 8 in part; Frebold and Tipper, 1970, p. 14-16), in contrast with the situation in East Greenland.

\section{INTERCONTINENTAL FAUNAL RELATIONSHIPS}

The known Jurassic ammonite successions in North America from Hettangian through early Oxfordian time were in seas that were either extensions of the Pacific Ocean or of the Arctic Ocean. Nevertheless, the North American ammonite successions during Early Jurassic time were essentially the same as those in Europe and elsewhere in the world. The same statement applies to the early Bajocian, except for an apparent absence of any taxa typical of the Leioceras opalinum zone in the Pacific Coast region (Arkell, 1956, p. 607, 608; Imlay, 1965, p. 1029-1031; Frebold, 1964a, p. 5; Frebold and Tipper, 1970 , p. 9,17$)$. After early Oxfordian time, the ammonite successions in the Gulf of Mexico region were in waters connected with both the Atlantic and Pacific Oceans. After early Bajocian time, the ammonite successions along the Pacific Coast of North America became differentiated from north to south because of fairly complete separation of the Arctic Ocean from the Pacific Ocean and the Mediterranean. Similar differentiation took place in Europe and presumably elsewhere.

During the middle to late Bajocian, the ammonite successions in western and northern North America became different from those in Europe and the Tethyan region. For example, in the Arctic region, the sole known representative of middle Bajocian Age consists of Arkelloceras, and there are no ammonites of definite late $\mathrm{Ba}$ jocian Age. In the Pacific Coast region, the ammonite successions of middle Bajocian Age contain some genera and species identical with taxa in Europe and the Tethyan region, but they differ in that they contain Alaskoceras, Pseudotoites, Parabigotites, Zemistephanus, and Arkelloceras (Westermann, 1964, 1969; Imlay, 1973, p. 1, 35, 36; Frebold and Tipper, 1970, p. 17). Of these, Pseudotoites is known elsewhere in Argentina, Chile, and western Australia (Westermann, 1967, p. 67, 68; 1969 , p. 27, 28, 129, 130, 157; Arkell, 1954, p. 592; Hillebrandt, 1970, p. 176, 187, 199).

Ammonites of late Bajocian Age in the arctic region of North America have not been definitely identified but could be represented by the lowermost occurrence of Cranocephalites. By contrast, in the Pacific Coast region, the ammonite successions of late Bajocian Age are definitely represented by such widespread genera as Spiroceras, Leptosphinctes, and Sphaeroceras. These successions differ from those in most parts of the world outside of the arctic region by the presence of Megasphaeroceras, Eocephalites, Parachondroceras, Sohlites, Lupherites, and Parastrenoceras and by lacking all genera of the Parkinsonidae. Of these ammonites, Megasphaeroceras and Eocephalites are reported elsewhere only in Chile and western Argentina, where they are associated with Spiroceras, Normannites, Teloceras, and Cadomites but are not associated with the Parkinsonid genera (Hillebrandt, 1970, p. 176, 201).

It appears, therefore, that the middle and late Bajocian ammonite faunas along the Pacific Coast of North and South America evolved in a similar manner. Both can be correlated fairly closely with sequences in Europe and in the Mediterranean region, but both include genera that appear to be restricted to areas bordering the $\mathrm{Pa}$ cific Ocean. Apparently, this development was entirely different from that in the arctic region of North America during the same time interval.

Bathonian ammonites belonging to genera characteristic of the Mediterranean (Tethyan) region and northwest Europe are present in the Pacific Coast region of southern Mexico and may occur in east-central Mexico. Elsewhere in North America, Bathonian ammonites have been found in the arctic region, southern Alaska, northern British Columbia, eastern Oregon, westernmost Idaho, and in the western interior region. The succession in southern Alaska and in the arctic region of Alaska and Canada consists, from bottom to top, mainly of the genera Cranocephalites, Arctocephalites, and Arcticoceras. The succession in the western interior consists of Paracephalites, which is similar to Arctocephalites, overlain by Warrenoceras, which is similar to Arcticoceras. Cobbanites, a genus similar to Vermisphinctes of late Bajocian Age, is associated with Cranocephalites in southern Alaska and with Paracephalites and Warrenoceras in the western interior of the United States and Canada. In eastern Oregon, Cobbanites is associated with a species of Parareineckeia that is similar to a species of Parareineckeia that occurs with Cranocephalites in southern Alaska. Both Warrenoceras in the western interior and Arcticoceras in southern Alaska are succeeded by species of Kepplerites similar to species in Greenland present below beds identified as earlier Callovian. These Bathonian ammonite successions, as far as is known, originated in the Arctic Ocean, had marine connections southward only through Yukon Territory and British Columbia into the western interior region, and were unlike any other Bathonian succession outside the arctic region. 
The Callovian ammonite succession in southern Mexico resembles that in Europe by containing Peltoceras, Erymnoceras, and Reineckeia and its subgenera. It also resembles that in western South America by containing Xenocephalites, Eurycephalites, and probably Neuqueniceras. Similarly, the Callovian succession in southern and east-central California bears some resemblance to that in Europe, as shown by the presence of such genera as Macrocephalites, Hecticoceras, and Peltoceras. The successions in east-central and northeastern California and in eastern Oregon are characterized, however, by such genera as Kepplerites, Xenocephalites, Pseudocadoceras, and Lilloettia. They do contain species in common with successions in British Columbia and Alaska but differ from those successions by lacking Cadoceras proper and its subgenera. In the western interior region, the earliest Callovian is represented by Kepplerites, Xenocephalites, Lilloettia, and Grossouvria, and the latest Callovian by a species of Quenstedtoceras similar to $Q$. henrici R. Douville from the latest Callovian of Europe. In arctic Alaska and arctic Canada, the Callovian is rather poorly represented by species similar to those of middle Callovian Age in southern Alaska. Overall, the Callovian ammonite sequences from British Columbia northward are dominated by ammonites characteristic of the arctic region, such as Kepplerites, Cadoceras, and Pseudocadoceras, but include genera found only in the Pacific region, such as Xenocephalites, Lilloettia, and Parareineckeia.

The Oxfordian ammonite sequences in the Gulf of Mexico region, in California, and in western Oregon contain the same genera found in beds of late middle to late Oxfordian Age in the Mediterranean region and are characterized by Perisphinctes (Dichotomosphinctes) and $P$. (Discosphinctes). They do not contain any ammonites of boreal origin, but in California and western Oregon they do contain Buchia concentrica (Sowerby) of such origin. These sequences have not yielded any ammonites of early to early middle Oxfordian Age, apparently because of the deposition at that time of highly saline deposits or red beds in the Gulf region and thick submarine volcanic materials in California and western Oregon.

Elsewhere in North America, the Oxfordian ammonite sequences are very similar to those in areas bordering the Arctic Ocean. The early to early middle Oxfordian is characterized by Cardioceras in association with Quenstedtoceras (Pavloviceras) and Prososphinctes. The late middle to late Oxfordian is characterized by Amoeboceras in association with the pelecypod Buchia concentrica (Sowerby).

Like the Oxfordian sequences, the Kimmeridgian ammonite sequences in the Gulf of Mexico region comprise genera typical of the Mediterranean region and southern Europe. They also do not contain ammonites of boreal origin, but in central Mexico they do contain the boreal pelecypods Buchia concentrica (Sowerby) and $B$. mosquensis (von Buch) in association with Idoceras and Glochiceras. In northwest Sonora, in California, and in western Oregon, the Kimmeridgian sequences contain ammonites of Mediterranean or nonboreal origin, such as Subdichotomoceras and Idoceras, associated with the Amoeboceras and A. (Amoebites) of boreal origin. Such ammonites in California and western Oregon are also associated with the boreal Buchia concentrica (Sowerby). From British Columbia northward to arctic Alaska and Canada, the faunal sequences do not contain ammonites that are definitely Kimmeridgian, although some of the occurrences of Amoeboceras could be of that age. Nonetheless, the top of the Kimmeridgian can be placed approximately at the top of beds containing an association of Buchia mosquensis (von Buch) with $B$. concentrica (Sowerby) and B. rugosa (Fischer).

The Tithonian ammonite sequences in the Gulf of Mexico region, in California, and in western Oregon include mostly genera that are similar to those in the Mediterranean (Tethyan) region and in South America, but they also include some ammonite genera that are found only, or mainly, in areas bordering the Pacific Ocean south of Oregon (Imlay, 1965, p. 1024, 1032). With these in California and Oregon are associated species of Buchia of boreal origin (Imlay and Jones, 1970, p. B5, B8). In contrast, from British Columbia northward to the arctic region of Canada, age determinations are based mainly on species of Buchia because ammonites are exceedingly rare (Frebold and Tipper, 1970, p. 14-16; Frebold, 1964a, p. 4; Jeletzky, 1965, 1966; Imlay and Detterman, 1973 , p. 21). This rarity contrasts markedly with the presence of a fair abundance of Tithonian ammonites in East Greenland and in the arctic region of Eurasia. Evidently the environmental conditions permitting the existence or the preservation of ammonites in arctic Alaska and Canada became less and less favorable from Oxfordian time to the end of the Jurassic.

In summation, Jurassic ammonite successions in North America were essentially the same as elsewhere in the world from the Hettangian until the early Bajocian. Differentiation of ammonite faunas began in the middle Bajocian, continued through the remainder of the Jurassic, and was greatest during the Bathonian and Tithonian (Volgian). This differentiation was due to partial to fairly complete isolation of the Arctic Ocean. That ocean opened southward to the Pacific Ocean through the Yukon Territory after Early Jurassic time. It opened southward from the East Greenland area into western Europe and the Mediterranean region in early Callovian time and later. Also, from middle Bajocian time onward, some new ammonite genera evolved in the Pacific Ocean. Some of these are known only, or mainly, from the $\mathrm{Pa}$ - 
cific Coast region of North and South America, or from parts of that region; some extended to New Zealand and beyond; a few spread into the Mediterranean region; but none reached into the arctic region (Arkell, 1956, p. 608-618; Imlay 1965, p. 1024; Enay, 1972).

\section{COMPARISONS OF LITHOLOGIC AND STRATIGRAPHIC FEATURES}

\section{GULF OF MEXICO AND NEARBY REGIONS}

\section{CUBA}

The Jurassic formations of Cuba have been discussed recently in detail by Khudoley and Meyerhoff (1971, p. 34-44, 59-67, 104-108). Their conclusions concerning the formations have been modified by certain Polish geologists, as discussed briefly herein and depicted in figure 21. At the base in western Cuba is the tremendously thick San Cayetano Formation, which is characterized by dark-gray to black carbonaceous shale, siltstone, and fine-grained sandstone. Locally it is slightly metamorphosed. It contains many carbonized plant stems and near the top contains marine pelecypods of probable Middle Jurassic age (Meyerhoff, 1964, p. 152, 153). It could be equivalent to all or part of the plant-bearing beds of Toarcian to Bathonian Age in southern Mexico. Its upper part is now dated as early middle Oxfordian on the basis of its gradational contact with the overlying Francisco Formation, which is mostly of middle Oxfordian Age (Wierzbowski, 1976, p. 141). Such an age is supported by the presence of the Oxfordian ammonites Perisphinctes (Dichotomosphinctes?) and P. (Discosphinctes) in the upper 35 to $100(?)$ meters of the San Cayetano Formation in the Sierra del Rosario (Myczynski and Pszczolkowski, 1976).

Conformably above the San Cayetano Formation in the Sierra del Rosario is the Francisco Formation, which ranges in thickness from 43 to 82 feet ( 13 to $25 \mathrm{~m}$ ), consists of rather soft shale, marl, limestone, and some sandstone, and contains ammonites of middle to probable early late Oxfordian Age (Kutek and others, 1976, p. 300-305; Wierzbowski, 1976, table 2 opposite p. 141, p. 152-159; Myczynski, 1976, p. 269, 292; Sánchez Roig, 1920, 1951; O'Connell, 1920; Jaworski, 1940; Burckhardt, 1930, p. 61, 62; Spath, 1931, p. 400; Arkell, 1956, p. 572,573$)$.

Conformably above the San Cayetano in the Sierra de los Organos is the Jagua Formation (Wierzbowski, 1976, p. 141-143; Hatten, 1967, p. 782), which consists of three members. The lower, or Azucar Member, ranges in thickness from 158 to 250 feet $(48$ to $76 \mathrm{~m}$ ) and consists of gray to black thin-bedded limestone that varies from dense to oolitic to sandy (Hatten, 1967, p. 782). The middle, or Jagua Vieja Member, ranges in thickness from 164 to 198 feet (50 to $60 \mathrm{~m}$ ), consists of dark-gray silty to sandy shale, marl, and limestone, contains many limestone concretions in the marly and shaly beds, and grades into the adjoining members. The upper, or $\mathrm{Pi}$ mienta Member, ranges in thickness from 131 to 198 feet $(40$ to $60 \mathrm{~m})$ and consists of gray, dense, platy thin-bedded limestone. Ammonites present in all three members (Wierzbowski, 1976, table 2 opposite p. 141) show that the Jagua Formation is of the same age as the Francisco Formation in the Sierra del Rosario. In particular, the presence in the Azucar Member of the ammonites Vinalesphinctes, Perisphinctes, Discosphinctes, Cubaochetoceras, and Glochiceras shows that its age is not older than middle Oxfordian.

The uppermost Jurassic in the Sierra del Rosario is represented by the Artemsia Formation, which consists mostly of thin- to medium-bedded, dense cherty limestone and tuffaceous shale. Its basal beds are of middle or late Oxfordian Age, as shown by the presence of the ammonites Mirosphinctes and Cubaochetoceras (Wierzbowski, 1976, p. 145; Kutek and others, 1976, p. 302306, fig. 6 on p. 307).

Most of the formation, however, contains ammonites of late early to early late Tithonian Age (Imlay, 1942; Judoley and Furrazola-Bermúdez, 1968, p. 3, 17, 23-25) and perhaps also contains a later Tithonian assemblage characterized by Dalmasiceras and Spiticeras (Housa and de la Nuez, 1973). The earliest Tithonian fossils were found 165-230 feet $(50-70 \mathrm{~m})$ above the base of the formation near Cinco Pesos (Wierzbowski, 1976, p. 145; Kutek and others, 1976, p. 315; Judoley and Furrazola-Bermúdez, 1965, p. 15), which means that the latest Oxfordian, all of the Kimmeridgian, and the earliest Tithonian must be accounted for by the basal $50 \mathrm{~m}$ of the Artemsia Formation.

The uppermost Jurassic beds above the Jagua Formation in the Sierra de los Organos are now placed in the Guasasa Formation of Herrera (1961, p. 11-14) by $\mathrm{Cu}-$ ban and Polish geologists (Wierzbowski, 1976, p. 144; Kutek and others, 1976 , p. 312). These geologists abandoned the term Vinales Limestone because it was poorly defined and had been used for different rock units in different areas. Thus, the term Vinales Limestone as used by Imlay (1942) includes both the Artemsia Formation in the Sierra del Rosario and the Guasasa Formation in the Sierra del Órganos. The Viñales Limestone as used by Khudoley and Meyerhoff (1971, p. 10-11) and by Judoley and Furrazola-Bermúdez (1968, p. 17) represents the lower member of the Guasasa Formation.

The Guasasa as used by these geologists ranges in thickness from about 4,265 to 4,600 feet $(1,300$ to 1,400 $\mathrm{m})$ and consists of two members. Its upper member is 


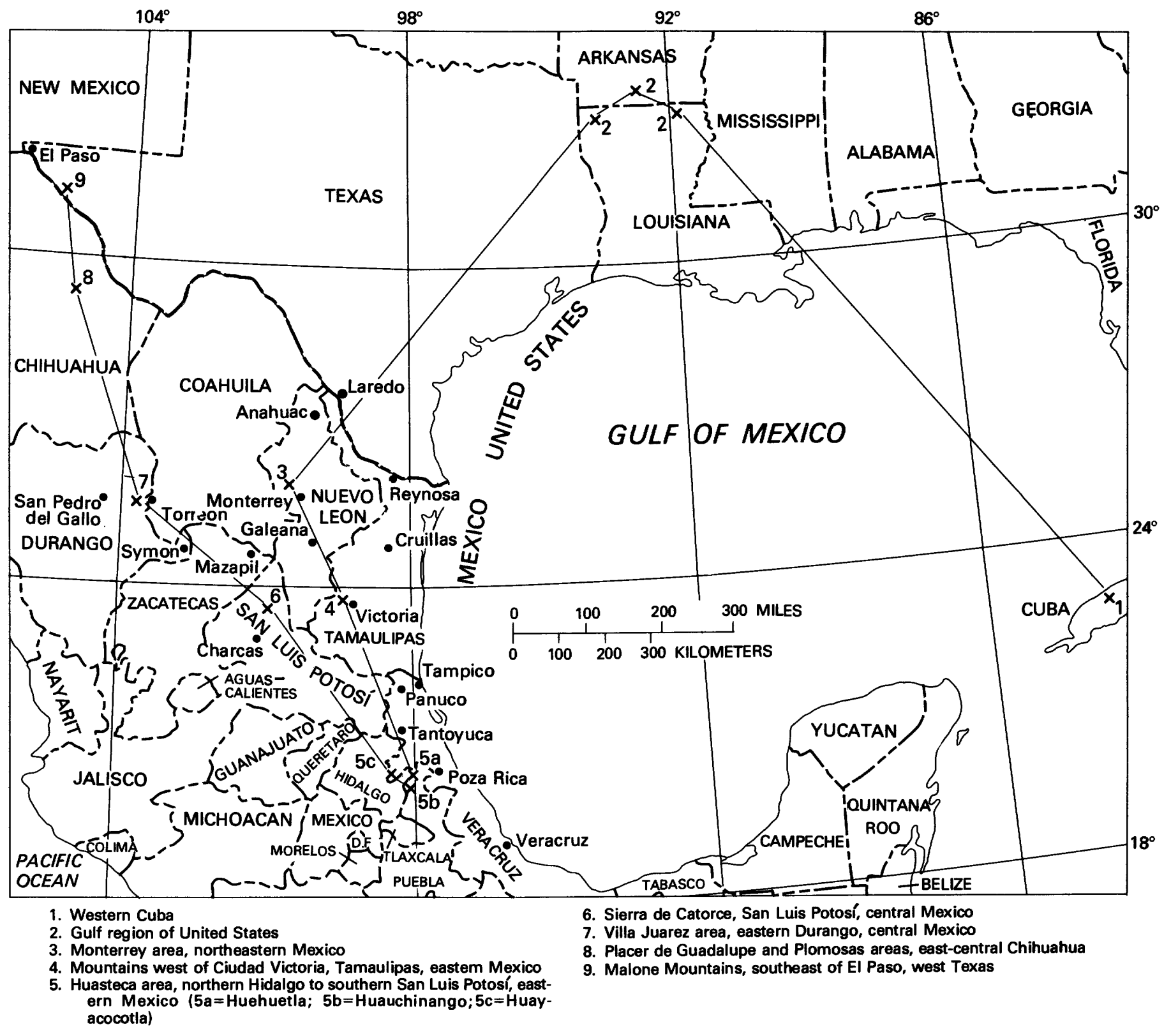

FIGURE 17.-Index map of Jurassic areas in the Gulf of Mexico and nearby regions. Numbers 1 to 9 refer to stratigraphic sequences shown in figure 21 .

990-1,320 feet $(300-400 \mathrm{~m})$ thick and consists of hard, compact, gray to black, highly fossiliferous thin- to thickbedded limestone. Its lower member, the San Vicente Member (Herrera, 1961, p. 11), is at least 3,280 feet $(1,000 \mathrm{~m})$ thick. It consists of gray to black, mostly thickbedded to massive limestone, some dolomite, and in places lentils and concretions of chert. It is marked basally by a breccia composed bf rounded to angular black limestone fragments that have been interpreted as evidence for a disconformity (Herrera, 1961, p. 11; Judoley and Furrazola-Bermúdez, 1965, p. 20; Khudoley and Meyerhoff, 1971, p. 10-11).
The upper member of the Guasasa Formation has furnished ammonite assemblages at several levels, according to Housa and de la Nuez (1975). Of these, the lowermost, collected directly above the massive limestone of the lower member, contains Mazapilites, Protancyloceras, and Pseudolissoceras, of middle early Tithonian Age; the next higher contains Torquatisphinctes and Parapallasiceras of late early Tithonian Age; and the uppermost, obtained near the top of the Guasasa Formation, contains some early late Tithonian ammonites, which were described by Imlay (1942) as late Portlandian. 


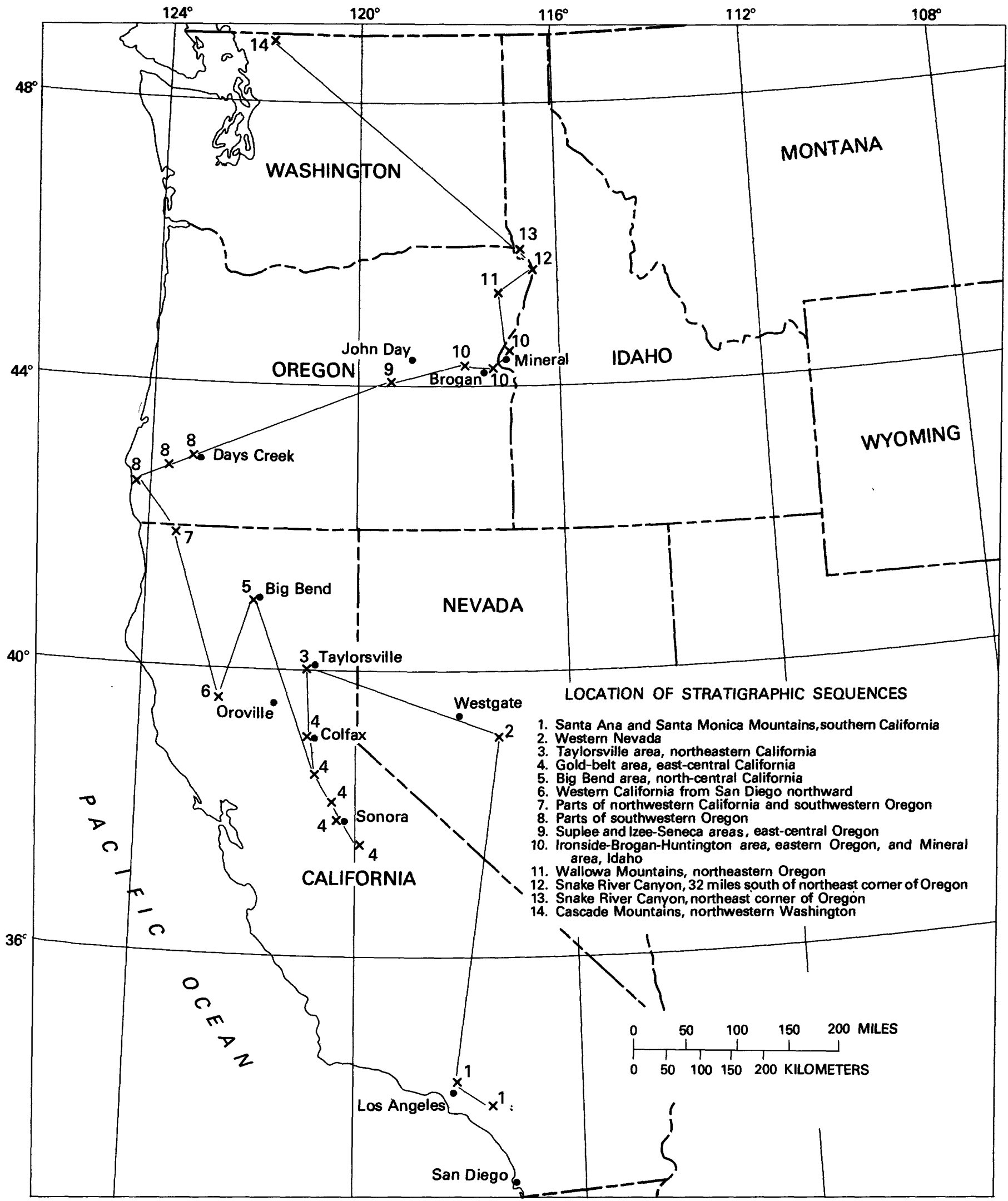

FIGURE 18.-Index map of Jurassic areas in the Pacific Coast region from California and Nevada to Washington. Numbers 1-9 refer to stratigraphic sequences illustrated in figure 22. Numbers 10-14 refer to stratigraphic sequences shown in figure 23. 


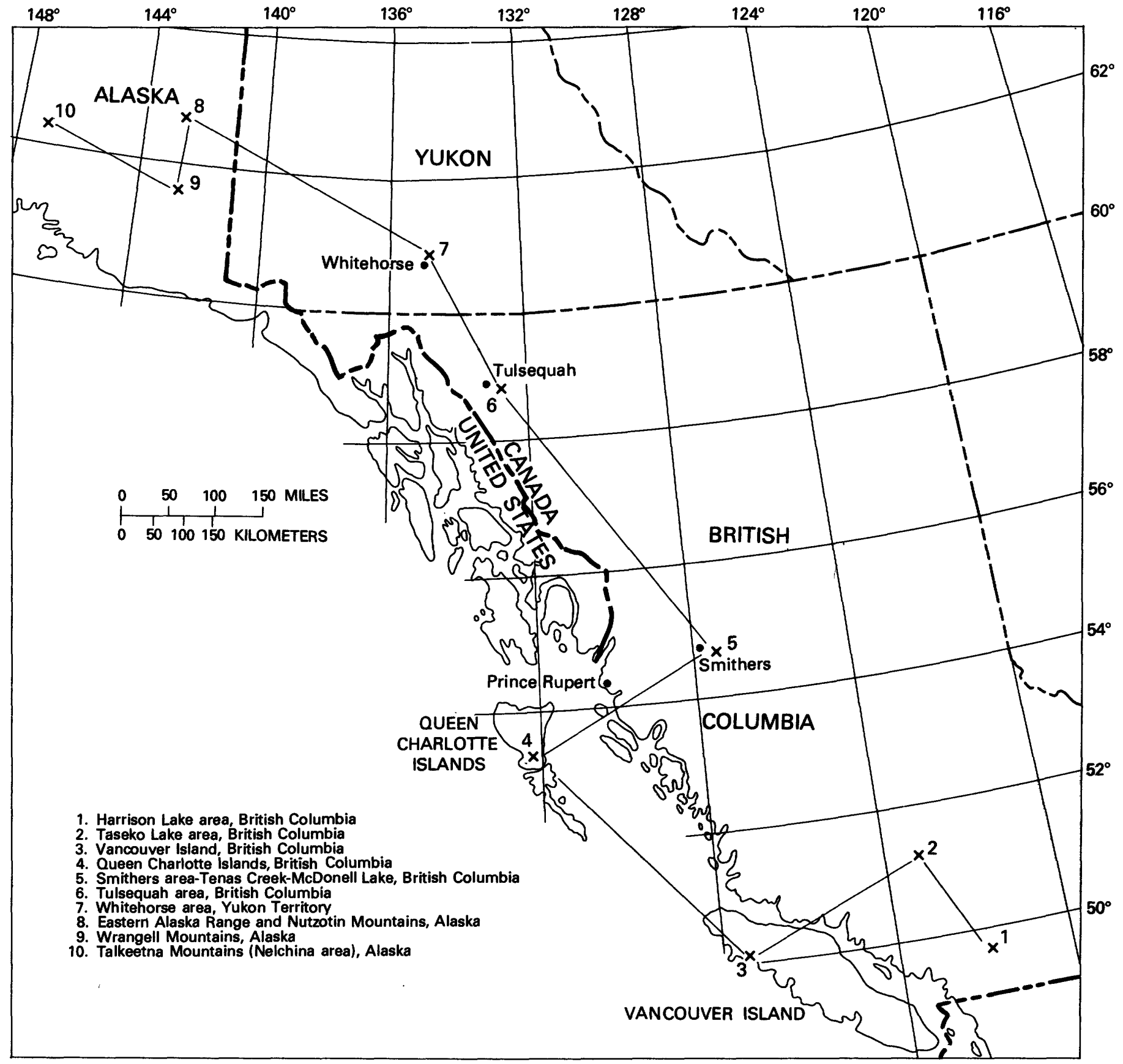

FIgURE 19.-Index map of Jurassic areas in the Pacific Coast region from British Columbia to southern Alaska. Numbers 1-10 refer to stratigraphic sequences shown in figure 24 .

This lower member of the Guasasa Formation has not been dated by fossils. Its age, however, must be mostly Kimmeridgian on the basis of its disconformable relationship with the underlying Jagua Formation of middle to late Oxfordian Age and on the presence of $\mathrm{Ma}$ zapilites in the basal beds of the upper member. The disconformity at the base of the lower member could be of latest Oxfordian or earliest Kimmeridgian Age, or both, and could be contemporaneous with deposition of the Buckner Formation in the Gulf of Mexico region.

The Jurassic may also be represented in north-central Cuba by the Punta Alegre Formation, which consists of 2,000 feet $(610 \mathrm{~m})$ or more mostly of salt and anhydrite, but includes some red to gray shale and siltstone, and is known only from four salt domes. (Khudoley and Meyerhoff, 1971, p. 40, 41). Some red silty shale in the 


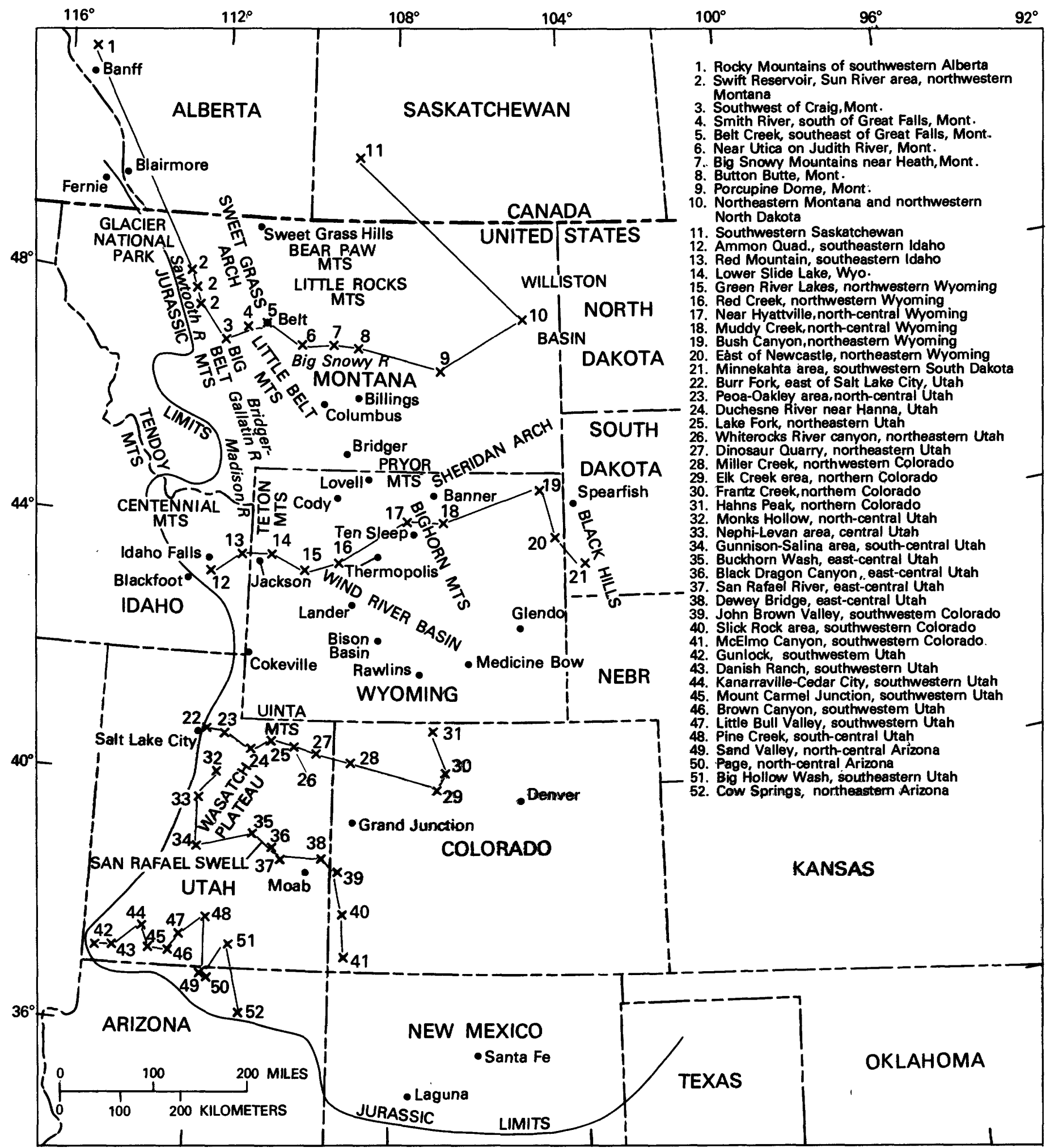

FIGURE 20.-Index map of Jurassic areas in the western interior region. Numbers 1-11 refer to stratigraphic sequences shown in figure 25; numbers 12-21 refer to sequences shown in figure 26; numbers 22-31 refer to sequences shown in figure 27; numbers 32-41 refer to sequences shown in figure 28; and numbers 42-52 refer to sequences shown in figure 29. Western and southern limits of Jurassic deposition are indicated by a solid line. 


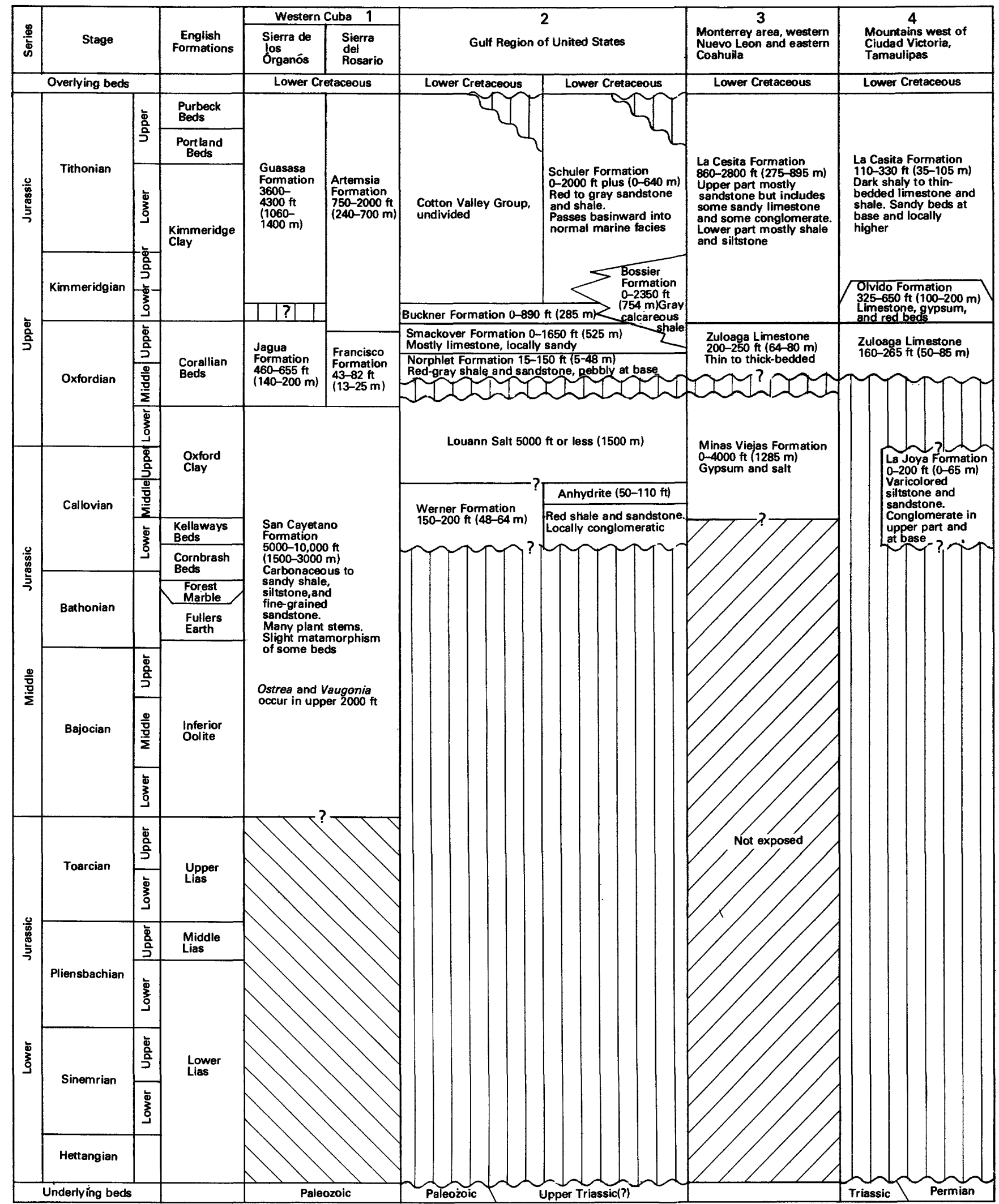

A. Western Cuba to Victoria, Mexico.

FIGURE 21.-CORRELATIONS AND COMPARISONS OF JURASSIC ROCKS IN THE GULF OF MEXICO AND NEARBY

REGIONS. Vertical lines indicate strata as missing; right-diagonal lines indicate strata are not exposed; left-diagonal lines indicate lack of fossil data; wavy lines indicate unconformity or disconformity; jagged lines indicate gradational or indefinite contact. Column numbers refer to locations shown on figure 17. 


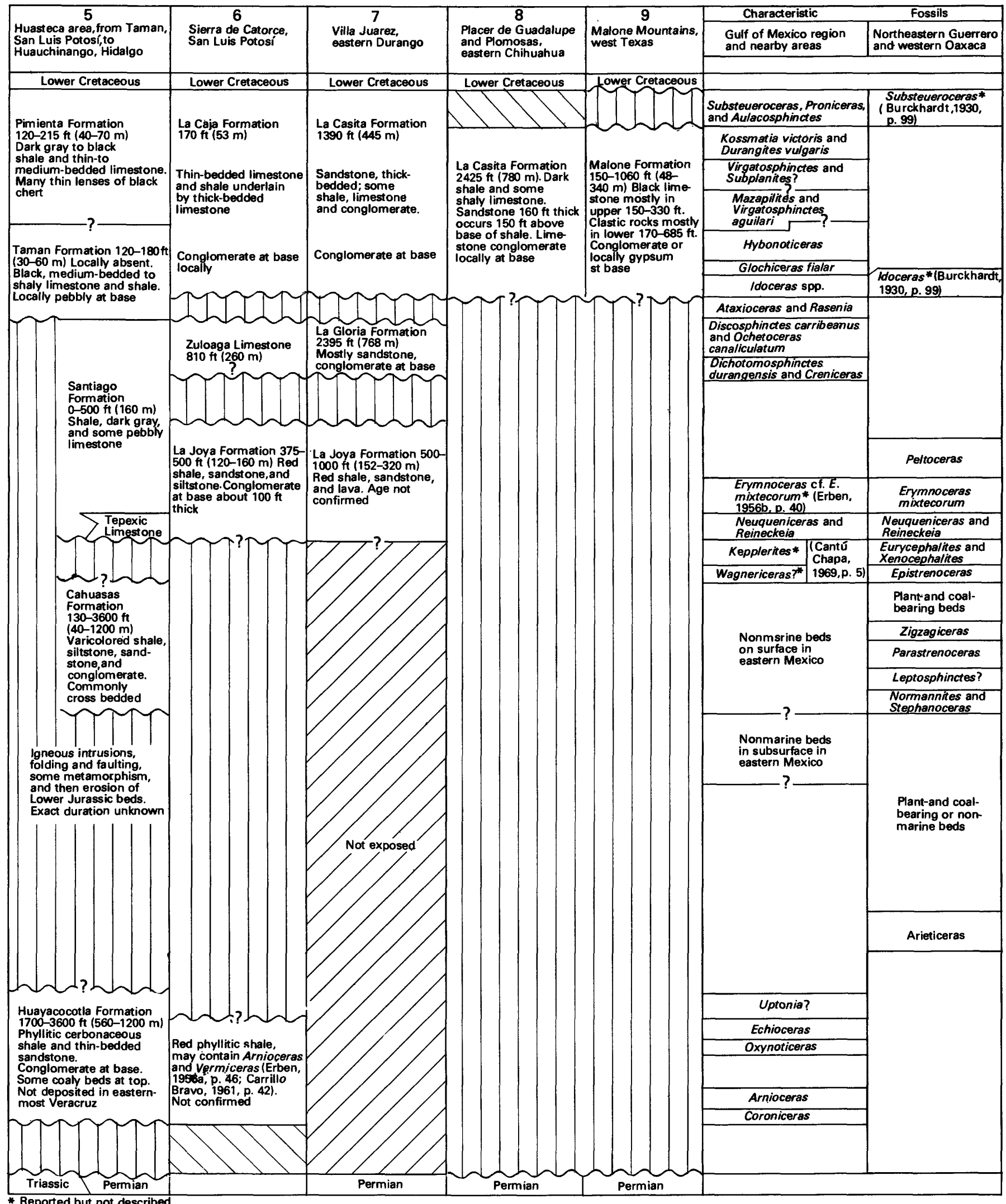

* Reported but not described

B. Huasteca area, Mexico, to Malone Mountains, Tex. 
salt has furnished pollen dated as post-Permian and preCretaceous (Meyerhoff and Hatten, 1968, p. 327). An Early to Middle Jurassic age is favored by Meyerhoff, and an Early to Late Jurassic age, older than the Artemsia Formation, is favored by Khudoley (Khudoley and Meyerhoff, 1971, p. 38). Apparently both geologists favor correlation of the Punta Alegre Formation with the Louann Salt and probable equivalent salt masses in northeastern and southeastern Mexico.

\section{GULF REGION OF THE UNITED STATES}

The lithologic characteristics, stratigraphic relationships, and ages of the Jurassic formations of the southeastern United States have been discussed in many papers (Weeks, 1938; Hazzard, 1939, p. 155-158; Hazzard and others, 1947; Philpott and Hazzard, 1949; Imlay, 1940b, 1943a, 1952a; Swain, 1944, 1949; Vestal, 1950; Applin and Applin, 1944, 1953, 1965, p. 18-29; Forgotson, 1954; McKee and others, 1956; Murray, 1961, p. 282 297; Jux, 1961; Thomas and Mann, 1963; Rainwater, 1967; Bishop, 1967, 1973; K. A. Dickinson, 1968; Maher and Applin, 1968, p. 9-11, pls. 2-4; Dinkins, 1968; Kirkland and Gerhard, 1971) and are presented briefly here. The stratigraphic relationships shown in figure 21 for formations younger than the Louann Salt are modified from a chart by K. A. Dickinson (1968, p. E7), which shows the changes in interpretations of those relationships during the past 30 years.

All these Jurassic formations in the southeastern States, although defined on the basis of subsurface sequences in southern Arkansas and northern Louisiana, are fairly consistent lithogically over great distances. All of them extend eastward from northeast Texas to Mississippi, and all except possibly the Werner Formation are present in the southwest corner of Alabama (Oxley and others, 1967; Rainwater, 1967, p. 191; Hartman, 1968; Oxley and Minihan, 1968; Maher and Applin, 1968, p. 9-11). In Alabama, however, some of the formational boundaries are less sharply defined than they are farther west.

The lithologic characteristics of the Werner Formation and the Louann Salt, as shown in figure 21, are particularly constant over hundreds of miles. The Werner Formation rests unconformably on upper Paleozoic rocks in northeastern Louisiana and in southern Arkansas (Imlay, 1943a, p. 1425; Hazzard and others, 1947, p. 486, 487 ), and it probably rests on the Eagle Mills Formation of Late Triassic age in southern Arkansas (Bishop, 1967, p. 245; Scott and others, 1961).

The Norphlet Formation consists mainly of red to gray shale and sandstone but locally contains anhydrite or is conglomeratic. It is overlain sharply by the Smackover Formation. It rests disconformably on the Louann
Salt in places, as shown by the fact that updip, it successively overlaps the Werner Formation, the Eagle Mills Formation, and then the underlying Paleozoic rocks. By contrast, in Clarke County, Miss., the Norphlet Formation, as interpreted by Badon (1975), passes laterally into the Louann Salt. He considers that the basal black-shale unit was formed in a depression on the surface of salt beds during a retreat of the evaporitic basin; that the overlying red siltstone unit was deposited in an intertidal to supratidal environment during further retreat of the evaporitic basin; and that the highest unit, consisting of red to gray quartz sandstone, was deposited in both intertidal and eolian environments near the end of deposition of the evaporitic deposits. Badon interprets the sharp contact of the Norphlet Formation with the overlying Smackover Formation as evidence of a major transgression related to partial opening of connections with a major ocean. His interpretation of the nature of the contact between the Norphlet Formation and the Louann Salt is not based on cores that show the contact, because such cores are not available in Clarke County. Evidently his interpretation needs confirmation by additional studies.

The Smackover Formation in the Arkansas-Louisiana-east Texas area is divisible into three units or members (K. A. Dickinson, 1968, p. E10-12). Of these, the upper unit is typically an oolitic limestone, but locally it is dolomitic or sandy. The middle unit is typically a dense limestone that contains anhydrite, but locally it is dolomitic, oolitic, or silty. The lower unit is a dense silty to shaly limestone, which is usually laminated.

The Smackover Formation in Mississippi and Alabama is divisible only into two units (Oxley, and others, 1967 , p. 30-34, figs. 3-5). Of these, the upper unit consists mostly of limestone, which varies from oolitic to dense to dolomitic and which at one place in Mississippi is replaced laterally by sandstone. The lower unit consists mostly of a dense limestone, which is locally dolomitic near its top and thinly laminated near its base, but which at two places in Mississippi is replaced laterally by sandstone. The Smackover Formation from east Texas to southwest Alabama is underlain concordantly by the Norphlet Formation, although the contact is sharp.

The Buckner Formation (Weeks, 1938), redefined as the lower member of the Haynesville Formation by Philpott and Hazzard (1949), is used in this paper as a formation for reasons discussed by K. A. Dickinson (1968, p. E8). It does not necessarily replace the local use of the term Haynesville Formation. As used by K. A. Dickinson (1968, p. E13-E17), the Buckner Formation consists mostly of red shale, anhydrite, and dolomite; locally contains salt, siltstone, sandstone, and limestone; is conformable with adjoining formations, except possibly where it thins; extends as a rather narrow lens-shaped 
body from east Texas to southwestern Alabama; pinches out northward; and interfingers southward with the Bossier and Smackover Formations (Bishop, 1973, p. 861).

The Bossier Formation as defined by K. A. Dickinson (1968, p. E17-19, figs. 3, 10, pl. 1) consists mostly of gray calcareous shale but includes a little shaly or oolitic limestone. It has been identified in northern Louisiana and adjoining parts of Arkansas and east Texas, where it passes laterally into the upper part of the Smackover Formation, the entire Buckner Formation, and the lower part of the Schuler Formation. All contacts are conformable.

The Schuler Formation consists of red, pink, to gray beds that pass basinward into thicker gray sandstone and shale and that extend from east Texas to southwestern Alabama (Imlay, 1943a, p. 1459; Swain, 1944, p. 594-600; Forgotson, 1954, p. 2490-2494; Oxley and others, 1967, p. 37-40). East of Louisiana, the formation consists of varicolored to red clastic sediments, which in southwestern Alabama contain a great deal of coarse sandstone and conglomerate. The formation rests on the Smackover or Buckner Formations in nearshore (northern) areas and on the Bossier Formation in offshore areas. This contact has generally been considered disconformable (Swain, 1944, p. 592, 1949, p. 1228; Forgotson, 1954, p. 2478, 2492) but, according to K. A. Dickinson $(1968$, p. E23), is probably conformable except in areas where the Buckner is thin or absent. The Schuler Formation is reported to be overlain disconformably by Lower Cretaceous beds in nearshore (updip) areas (Swain 1944, p. 609; Forgotson, 1954, p. 2490; Imlay, 1943a, p. 1467-1471).

Elsewhere in the southern United States, the Jurassic is represented in south Texas by both the Cotton Valley Group and the Smackover Formation (Halbouty, 1966 , p. $10,14,15,21$ ) and presumably also by the Louann Salt, as shown by the presence of salt domes. In southern Florida, the Jurassic is possibly represented by part of the Fort Pierce Formation, which consists of $380-590$ feet $(116-180 \mathrm{~m})$ of limestone, dolomite, and anhydrite, is overlain by beds containing the Aptian ammonite Dufrenoya, and has microfossils of both Late Jurassic and Early Cretaceous age (Applin and Applin, 1965, p. 18-29; Maher and Applin, 1968, p. 11).

The age of the Louann Salt has been variously interpreted (1) as Permian (Hazzard and others, 1947, p. 484), mainly on the basis of a disconformable relationship with the overlying Norphlet Formation; (2) as Late Triassic to Early Jurassic, on the basis of pollen and spores (Jux, 1961); (3) as Jurassic, because the conformably underlying Werner Formation rests unconformably on the Eagle Mills Formation, which contains Late Triassic plants (Scott and others, 1961); and (4) as early Late Jurassic, because the Louann Salt as well as similar evaporitic sequences in Mexico directly underlie beds of late Oxfordian Age and must have been covered by those beds shortly after deposition in order to escape extensive erosion (Imlay, 1940b, p. 12; 1943a, p. 1437-1438; 1952a, p. 974,1952 b, p. 1750,1751$)$. All these interpretations and the data on which they are based have been analyzed by Murray (1961, p. 283-287) and Bishop (1967, p. 248, 249), who conclude that the evidence favors deposition of the Louann Salt during Jurassic time prior to the late Oxfordian or prior to the deposition of the Norphlet Formation, which formed a seal over the salt. In addition, an age not older than Middle Jurassic for the Louann Salt is indicated by studies of palynomorphs obtained from cap rock overlying halite on the Challenger Knoll near the middle of the Gulf of Mexico (Kirkland and Gerhard, 1971, p. 681).

The Louann Salt and the underlying Werner Formation were assigned an early Oxfordian (Divesian) Age by Imlay (1943a, p. 1437, 1438), partly because similar evaporitic deposits in Mexico underlie upper Oxfordian beds (Imlay, 1943a, p. 1506-1508) and partly because conditions were unfavorable for salt deposition in southeastern Mexico before latest Callovian time (Imlay, 1943a, p. 1438, 1508-1510; 1953c, p. 31). These reasons have since been strongly upheld by Viniegra $0 .(1971$, p. 480 , 484). The term Divesian, as used by this writer in 1943 , however, followed Spath (1933, p. 872) and included the zones of Quenstedtoceras lamberti and Peltoceras athleta. As these zones are now placed in the upper Callovian (Arkell, 1946, p. 12, 13; 1956, p. 10, Cariou and others, 1971, p. 93), the Louann Salt is herein correlated with the upper Callovian and also with the lower to lower middle Oxfordian as now defined (Callomon, 1964, p. 288, 289; Cariou and others, 1971, p. 93, 94.

The Werner Formation, however, could be somewhat older than latest Callovian, provided its origin is related to major changes in the Gulf region that coincided with major marine invasions of the western interior of North America and of southern Mexico from the Pacific Ocean. Of these invasions in the western interior region, the most restricted took place during late middle to late Bajocian time (Imlay, 1967b, p. 54), a fairly extensive invasion occurred during latest Bathonian to early Callovian time (Imlay, 1967b, p. 56), and the greatest invasion came during latest Callovian to middle Oxfordian time (Imlay, 1957, p. 471). The sea partially withdrew during early Bathonian time and during middle to early late Callovian time. Comparisons with the ammonite sequence in Mexico (see fig. 21) show that the first two marine invasions from the Pacific Ocean took place there at the same time as in the western interior region, but that the third, if present, is represented by evaporitic deposits and red beds below marine beds of late Oxfordian Age, and, locally in east-central Mexico, by sparsely 
fossiliferous marine beds between normal marine beds of middle Callovian and late Oxfordian Ages.

Dating the Werner Formation as Early Jurassic or as Middle Jurassic older than Callovian is unreasonable considering (1) the tectonic events that occurred in eastcentral Mexico during those times, (2) the fact that the Bajocian sea in Mexico was apparently restricted to a small area near the Pacific Ocean (fig. 6), and (3) that in east-central Mexico the Bajocian as well as part of the Bathonian are accounted for by continental beds (fig. 7). Overall, dating of the Werner Formation as early to middle Callovian is favored because the marine invasion across southern Mexico reached the Gulf region in eastcentral Mexico during that time, and this area presumably was one source for saline deposits later in the Callovian and Oxfordian.

The time represented by the disconformity between the Louann Salt and the overlying Norphlet Formation is probably very short because there appears to have been little, if any, erosion of the salt (Andrews, 1960, p. 220, 225; Bishop, 1967, p. 248, 249). This condition could be explained by a sudden deepening of the Gulf region, or of the marine inlets from the Atlantic and Pacific Oceans, which allowed sea water to invade widely beyond the area of salt deposition. The presence of conglomerate and other clastic sediments at the base of the Norphlet Formation could then be explained partly by reworking of soil as the sea advanced beyond the salt basins and partly by uplift of landmasses bordering the Gulf region. Thus, the Coahuila Peninsula in northern Mexico at that time contributed a great deal of sandstone and gravel, called the La Gloria Formation, which passed seaward into the Zuloaga Limestone, which closely resembles the Smackover Formation. Similar uplifts in Mississippi and southwest Alabama apparently started at the same time (Oxley and others, 1967, p. 47-48).

The ages of the Jurassic formations above the Louann Salt are fairly well established. Thus, the middle and upper parts of the Smackover Formation have yielded late Oxfordian ammonites (Imlay, 1945, p. 274, pl. 41, figs. 7-14) that are identical specifically with ammonites in the lower member of the Jagua Formation in Cuba, in the upper part of the Santiago Formation in eastern Mexico, and in the La Gloria Formation at San Pedro del Gallo in central Mexico. As the Norphlet Formation grades upward into the Smackover Formation, and as it is much thinner, it is probably also of late Oxfordian Age, or no older than middle Oxfordian.

The Buckner Formation has not yielded fossils of any value in determining its age. It was once dated as probably early Kimmeridgian on the basis of stratigraphic position in Arkansas between the Smackover Formation, which contains late Oxfordian ammonites, and the Cotton Valley Formation (now called Group), which contains middle Kimmeridgian fossils. Such an age was supported by an apparent southward gradation of the Buckner Formation into the basal part of the Cotton Valley Group, which in northern Louisiana contains early Kimmeridgian ammonites (Imlay, 1943a, fig. 8 on p. 1429, p. 1471; 1945 , p. 258-259). Subsequent studies in northeastern Texas and southern Arkansas indicate that the lower part of the Buckner Formation interfingers basinward with the highest part of the Smackover Formation (Swain, 1949, p. 1207, 1219-1223; K. A. Dickinson, 1968, p. E11) and, therefore, could be partly of latest Oxfordian Age in some areas.

The age of the lower part of the Cotton Valley Group, as just discussed, is definitely Kimmeridgian, and its basal part south of the southern limit of the Buckner Formation is earliest Kimmeridgian. The upper part of the Cotton Valley Group between east Texas and southwest Alabama has furnished only a few pelecypods (Imlay, 1943a, p. 1472). It is dated as Jurassic mainly on the basis of stratigraphic position beneath the Hosston Formation (Lower Cretaceous) (Swain, 1944, p. 609; Oxley and others, 1967, p. 38), with which it is disconformable in updip areas.

\section{CENTRAL AND NORTHEASTERN MEXICO}

Most of the Jurassic formations of central and northeastern Mexico are lithologically and stratigraphically closely similar to the Jurassic formations in the southeastern United States. Thus, the Zuloaga and the La Gloria Formations in Mexico match the various facies of the Smackover Formation and contain the same ammonites (Imlay, 1943a, p. 1484). The Olvido Formation, which overlies the Zuloaga Limestone at various places in the mountains from Victoria, Tamaulipas, northward to eastern Coahuila, is lithologically identical with the Buckner Formation and occupies the same stratigraphic position (Imlay, 1943a, p. 1495; Carrillo-Bravo, 1963, p. 16). The overlying La Casita Formation in Mexico occupies the same stratigraphic position as the Schuler Formation of the Cotton Valley Group of the southeastern United States. It differs by being gray to black, instead of reddish, and commonly is marked by a basal conglomerate in areas where the Olvido Formation is absent. The La Caja Formation is the thin offshore equivalent of the La Casita Formation and Olvido Formation and the stratigraphic equivalent of the Cotton Valley Group plus the Buckner Formation. The La Caja Formation in contrast to the dark offshore facies of the Cotton Valley Group is much thinner and contains phosphatic beds.

Below the Zuloaga Limestone in the Sabinas basin of northeastern Mexico is a thick mass of salt and anhydrite, called the Minas Viejas Formation, that extends from eastern Coahuila southeastward into Nuevo Leon 
and Tamaulipas and northeastward into southernmost Texas (Humphrey, 1956, p. 25; Weidie and Wolleben, 1969; Wall and others, 1961; Murray, 1961, p. 284). This evaporitic sequence occupies the same stratigraphic position as the Louann Salt but differs by containing much more anhydrite.

Outside the Sabinas Basin at many places, the $\mathrm{Zu}$ loaga Limestone and the equivalent La Gloria Formation are underlain unconformably by red or varicolored shale, sandstone, and conglomerate and locally by some redweathering lava. These deposits, in turn, rest unconformably on rocks of Triassic, Permian, or older age (Imlay, 1943a, p. 1475-1477; 1953c, p. 20-28, fig. 4; Imlay, Cepeda, and others, 1948, p. 1753-1758; Pérez Fernández and Díaz Gonzalez, 1964; Mixon and others, 1959; Mixon, 1963; Carrillo-Bravo, 1961, p. 34-51). These red beds cannot yet be dated closely at any place and can be dated definitely as Jurassic at only a few places. One of these places is west of Charcas in north-central San Luis Potosí, where 160 feet $(50 \mathrm{~m})$ of red, pink, and gray conglomerate and sandstone, called the La Joya Formation, lies unconformably between the Zuloaga Limestone and Upper Triassic marine beds (Martinez Pérez, 1972, p. 346-347).

Another place where a Jurassic age has been established is in the mountains west of Victoria, Tamaulipas, where the red beds are divisible into two formations that are separated by an angular unconformity. The lower red bed formation, referred to variously as the La Boca Formation (Mixon and others, 1959, p. 762; Mixon, 1963, p. 28 ) or as the Huizachal Formation (Carrillo-Bravo, 1961, p. 34), attains a thickness of 6,500 feet $(2,000 \mathrm{~m})$ or more and contains plant fossils that have been identified as Late Triassic to Early Jurassic (Mixon, 1963, table 1, p. 31). The upper red bed formation, called the La Joya Formation, attains a thickness of $165-260$ feet $(50-80 \mathrm{~m})$ and has not been dated by fossils. Carrillo-Bravo (1961, p. $34 ; 1963$, p. 14,15$)$ considered it to be younger than Early Jurassic on the basis of its stratigraphic position and probably of Callovian to early Oxfordian age on the basis of comparisons with Jurassic sequences in east-ceniral and northern Mexico (Carrillo-Bravo, 1961, p. $51 ; 1965$, p. $78,81-88$ ).

\section{EAST-CENTRAL MEXICO}

Studies of the Jurassic sequence exposed in the mountainous Huasteca area and penetrated by drilling in the Tampico embayment to the east have produced paleontologic, stratigraphic, and structural evidence that most of the salt masses in the Gulf region are closely related in age to the overlying Upper Jurassic limestones, are probably not older than Callovian, and are definitely not older than Middle Jurassic. All evidence indicates that conditions during the Early Jurassic made the accumulation of thick masses of salt and anhydrite impossible in the western part of the Gulf region. Thus the marine Huayacocotla Formation of Sinemurian and questionable early Pliensbachian Age is carbonaceous, contains considerable plant material at both top and bottom, and contains some coal at its top. It lies unconformably between Upper Triassic and Middle Jurassic red beds; was strongly folded, faulted, and slightly metamorphosed before the overlying red beds were deposited; and, finally, was intruded by diabase before marine $\mathrm{Cal}$ lovian beds were deposited (Díaz-Lozano, 1916; Burckhardt, 1930, p. 12-20; Imlay, 1943a, p. 1497; Imlay, Cepeda, and others, 1948, p. 1750-1753; Carrillo-Bravo, 1965 , p. $85,87,92-95$ ). The diabase may actually be older than the Middle Jurassic red beds (Cahuasas Formation), but in the place where the diabase is exposed those red beds are missing.

The overlying Cahuasas Formation (Carrillo-Bravo, 1965 , p. 87-88), formerly included in the Huizachal Formation (Imlay, Cepeda, and others, 1948, p. 17551757; Erben, 1956a, p. 31-34, 1956b, p. 9-12), rests with angular unconformity on the Huayacocotla Formation. The Cahuasas is overlain disconformably by the Santiago Formation or in places by the Taman Formation, is locally absent within its area of distribution, is more extensive in the subsurface than the Huayacocotla Formation (Lopez Ramos, 1972, compare sections CC to $\mathrm{FF}$ ), and is dated as Bajocian to Bathonian on the basis of stratigraphic and structural relationships. The Cahuasas Formation must be older than Callovian because in outcrops it lies disconformably below beds of early to middle Callovian Age (Erben, 1956b, p. 12; Carrillo Bravo, 1965, p. 88; Cantú Chapa, 1971, p. 36), and in the subsurface it probably underlies beds of latest Bathonian Age (Cantú Chapa, 1969, p. 4, 5). The Cahuasas must be younger than Toarcian because in the Pemex-Comales test well 102 , about $75 \mathrm{~km}$ south-southeast of Tampico, it passes downward into beds containing plant species identical with species that in Oaxaca occur in the upper part of the Rosario Formation, which part is dated as early Middle Jurassic (Erben, 1957a, p. 45; 1956a, p. 137).

The Jurassic formations overlying the Cahuasas Formation are all marine. On the outcrop, they consist of the Santiago Formation (Cantú Chapa, 1969, p. 5, 6; 1971, p. 21-24, 37) of early or middle Callovian to late Oxfordian Age, the Taman Formation of Kimmeridgian to earliest Tithonian Age, and the Pimienta Formation, which represents the remainder of the Jurassic. All these formations are present also in the subsurface of the Tampico embayment (see lists in Lopez Ramos, 1972, p. 304$317)$, but, in addition, about 45 miles $(72 \mathrm{~km}$ ) northwest of Poza Rica, Veracruz, the Santiago Formation is underlain by the marine Palo Blanco Formation (Cantú 
Chapa, 1969, p. 5), which is above red beds. The age of the Palo Blanco Formation is early Callovian, on the basis of the presence of Kepplerites in three test wells. It is possibly also late Bathonian, on the basis of small ammonites resembling Wagnericeras that were found about 79 feet $(24 \mathrm{~m})$ below Kepplerites in the Palo Blanco test well 112 and about 750 feet $(230 \mathrm{~m})$ above the bottom of the well, which did not penetrate into red beds. In another nearby well (Pemex-Coyote 3), Kepplerites was obtained about 950 feet $(290 \mathrm{~m})$ above red beds. Evidently an appreciable thickness of marine beds that could be of Bathonian Age is present below the occurrences of Kepplerites.

The age limits of the Santiago Formation are well established (Cantú Chapa, 1969, p. 6; 1971, p. 22-24). A late Oxfordian Age for the upper part of the formation has been demonstrated at many places by the presence of ammonites identical with species in the Jagua Formation of Cuba, in the Smackover Formation of the southeastern United States, and in the Zuloaga and La Gloria Formations of central and northeastern Mexico. A late early Callovian Age for the basal part of the formation is shown by the presence of Neuqueniceras in a local facies called the Tepexic Limestone (Cantú Chapa, 1969, p. 4; 1971, p. 18, 24, 36). Above this limestone in the lower part of the Santiago Formation, the middle Callovian is probably represented by Reineckeia at two localities (Cantú Chapa, 1971, p. 24) and by Erymnoceras at one locality (Erben, 1956b, p. 40; 1957a, p. 47).

The Tepexic Limestone is dated as late early Callovian because it contains both Neuqueniceras and Reineckeia. In Europe, Neuqueniceras ranges through at least the middle part of the lower Callovian and is associated at the top of its range with the lowest occurrences of $R e$ ineckeia and R. (Reineckeites) (Zeiss, 1956, p. 83; Bourquin, 1968, p. 23, 155-157), both of which range higher into the lower part of the upper Callovian. In Japan, Neuqueniceras occurs below Kepplerites (Sato, 1962, p. $18,19,50,56,75-79$ ), which does not range above the lower Callovian. In Argentina, Neugueniceras occurs above Macrocephalites of earliest Callovian Age and below Reineckeia, and is correlated with the Sigaloceras calloviense zone of Europe (Hillebrandt, 1970, p. 171, 191). In Oaxaca and Guerrero, Mexico, Neuqueniceras is associated with Reineckeia, but its stratigraphic and age relations have not yet been established with respect to such taxa as $R$. (Reineckeites), $R$. (Kellawaysites), Xenocephalites, Choffatia, Subgrossouvia, Eurycephalites, and possibly Macroce phalites or Lilloettia (CantúChapa, 1971, p. 19). The evidence to date shows that Neuqueniceras occurs definitely in beds of early Callovian Age and has not yet been found in younger beds.

In contrast to this age evidence for the upper and lower limits of the Santiago Formation, the middle part of the formation has yielded no ammonites of late Callovian Age and none that are definitely of early Oxfordian Age. The early Oxfordian may be represented, however, by one deformed ammonite that Cántu Chapa (1971, p. 23) assigned to the subgenus Ochetoceras (Fehlmannites) and by other ammonites that Erben (1957a, p. 47) assigned to Creniceras renggeri (Oppel) and to Peltoceras (Parapeltoceras) annulare (Reinecke).

Any age determination based on these ammonites must await adequate descriptions and illustrations and probably the discovery of other ammonite genera. At present, the total age range of Fehlmannites is unknown because the genus is recorded from only one locality in Switzerland (Jeannet, 1951, p. 2, 89). The generic status and exact stratigraphic position of Parapeltoceras is unknown, according to Arkell and others (1957, p. L336). The genus Creniceras in Europe is most common in the lower and middle Oxfordian but ranges from the uppermost Callovian into the Kimmeridgian (from the upper part of the Quenstedtoceras lamberti zone into the $A u$ lacostephanus eudoxus zone). Among the species present, Creniceras renggeri (Oppel) ranges from the top of the Quenstedtoceras lamberti zone to the Cardioceras cordatum zone (Arkell, 1939, p. 151; 1956, p. 43, 47, 59, 74), Creniceras crenatum (Bruguière) ranges from the Cardioceras cordatum zone to the Gregoryceras transversarium zone (Jeannet, 1951, p. 101; Ziegler, 1956, p. 572), and Creniceras dentatum (Reinecke) occurs entirely in the Kimmeridgian (Ziegler, 1956, p. 567; Enay and others, 1971).

The scarcity or absence of fossils of late Callovian to middle Oxfordian Age in outcrops of the Santiago Formation was ascribed by Cantú Chapa $(1971$, p. 22,37$)$ to small exposures, incomplete sequences (except at Huehuetla in Hidalgo), poorly fossiliferous beds, and the local absence of beds of that age. He notes, however, that no fossils of that age have yet been found in the subsurface-a fact that he cannot explain biogeographically (Cantú Chapa, 1971, p. 37). Their absence or scarcity during late Callovian to early middle Oxfordian time could be explained readily, however, if the major evaporitic sequences in the Gulf region were deposited during that time. This seems reasonable, considering the position of both the Louann Salt and the Minas Viejas Formation directly below beds of late middle Oxfordian Age, the position of the Salina Formation in the Isthmus of Tehuantepec a little below beds of Kimmeridgian Age (Burckhardt, 1930, p. 97; Imlay, 1953a, p. 28-30; Contreras and Castillón, 1968, p. 244), and the lack of evidence that these evaporitic sequences underwent any appreciable erosion at all before the overlying beds were deposited (Andrews, 1960, p. 220, 225; Bishop, 1967, p. 248, 249). Dating the major salt masses in the Gulf region as late Callovian to early middle Oxfordian does not 
bar the deposition of some salt at other times during the Jurassic or Cretaceous, as has been demonstrated (Imlay, 1943a, p. 1529; K. A. Dickinson, 1968, p. E13-E15; Viniegra O., 1971, p. 478, 482-485).

If this explanation is correct, then the poorly fossiliferous beds in the middle part of the Santiago Formation could have been deposited during late Callovian to middle Oxfordian time in waters that were more saline than normal sea water, that entered east-central Mexico from the Pacific Ocean, and that were a source for at least part of the thick masses of salt and anhydrite deposited in places around the Gulf of Mexico. That the marine waters came from the southwest or west is indicated by eastward thinning and wedging out of Middle and Upper Jurassic marine sedimentary rocks in the Tampico embayment, according to Viniegra O. (1971, p. 482, 483). Similarly, Cantú Chapa (1973) stated, "In the northwestern Poza Rica area the Middle Jurassic transgression began during the Bathonian. Later it advanced to the central, east and west parts, and the covered area is characterized by distinct transgressive lithofacies."

The marine invasion from the Pacific Ocean during salt and anhydrite deposition, as discussed by Viniegra O. (1971, p. 482, 484, 486, fig. 10 on p. 492), could have been from the south across the present Isthmus of Tehuantepec, or from the west or southwest across the present States of Puebla, Oaxaca, and Guerrero, or by both routes. The distribution of Jurassic rocks in southern Mexico (Viniegra O., 1971, p. 481, 483; Sánchez Mejorada and Lopez Ramos, 1968) shows that both marine connections probably existed during Kimmeridgian to Tithonian time but that a connection from the southwest across Guerrero was most likely during Callovian and Oxfordian time. The presence of either or both of these marine routes does not bar another marine connection from the Atlantic Ocean while the Louann Salt was accumulating.

In summation, all available faunal and stratigraphic evidence shows that the upper Bathonian to middle Callovian marine beds in east-central Mexico were deposited in a sea that transgressed northward or northeastward from the Pacific Ocean. This sea did not reach the Gulf of Mexico region until early or (more probably) middle Callovian time. Apparently, it then became a source of salt and anhydrite deposited during late Callovian to early middle Oxfordian time in southeastern and northeastern Mexico and in the southeastern United States. Deposition of these thick evaporitic deposits during that time is favored by their stratigraphic position, by the lack of appreciable, if any, erosion of their upper surfaces, and by the lack or scarcity of marine fossils of that time in eastcentral Mexico within a sequence that appears to be stratigraphically continuous from early Callovian to late Oxfordian.

\section{SOUTHEASTERN MEXICO}

In the Chiapas salt basin the Jurassic is represented by a thick mass of salt and associated red to black shale overlain by a thin unit of red beds, which is overlain in turn by several hundred feet of limestone, marl, and black shale of early Kimmeridgian to early Neocomian Age (Burckhardt, 1930, p. 97, 98; Imlay, 1943a, p. 15061508; Viniegra $0 ., 1971$, p. 482, 484). Outside the salt basin, the late Jurassic is apparently represented mainly by red beds that underlie beds of Early Cretaceous age. On the Chiapas massif, south of the salt basin, some early Kimmeridgian ammonites are reported to be within red beds that underlie Lower Cretaceous beds (Viniegra O., 1971, p. 479, 480, 483).

\section{EASTERN CHIHUAHUA AND WEST TEXAS}

Upper Jurassic beds exposed in eastern Chihuahua near Placer de Guadalupe and Plomosas (Bridges, 1965, p. 66-76, 118-120, 132-134) contain ammonites of the same age as those in the Malone Formation in west Texas (Imlay, 1952a, p. 973; Albritton, 1938, p. 17581761; Cragin, 1905). The beds in Chihuahua differ by consisting mostly of dark calcareous shale and by being much thicker. Also, the sequence in eastern Chihuahua is overlain by 630 feet ( $192 \mathrm{~m}$ ) of limestone and marl that could be uppermost Jurassic, whereas the Jurassic sequence in west Texas contains Kossmatia near its top and is overlain by a conglomerate at the base of the Cretaceous(?) Torcer Formation. Upper Oxfordian beds have not been found in either area, in contrast to their presence throughout most of central, eastern, and southern Mexico.

\section{PACIFIC COAST REGION}

\section{WESTERN MEXICO}

Jurassic beds have been identified near the Pacific coast of Mexico in northwestern Oaxaca, Guerrero, Michoacan, western Sonora, and Baja California. Most occurrences have not been described in detail and some shown on the Geologic Map of Mexico (Sánchez Mejorada and Lopez Ramos, 1968) have not been described at all. That map does not show the presence of Jurassic rocks in Baja California, although Buchia piochii (Gabb), of latest Tithonian Age, is reported to occur at La Punta de San Hipolito, northwest of Bahia Ballenas (Lopez Ramos, 1974 , p. 392; Minch, 1969, p. 42).

Furthermore, the Jurassic rather than the Triassic may be represented by specimens of the pelecypod Otapiria from Arroyo de San Jose, which is south of Punta Canoas in the central part of Baja California (Lopez Ramos, 1974, p. 375). Such an age is suggested by the close 
resemblance of these specimens to $O$. tailleuri Imlay (Imlay, 1967a, p. B3-B6), which is associated with the Early Jurassic (Sinemurian) ammonites in northern Alaska (Imlay and Detterman, 1973, p. 16, 17).

In northwestern Oaxaca and northeastern Guerrero, the Jurassic sequence consists mostly of Toarcian to Oxfordian beds that range from 2,300 to 2,950 feet (700 to $900 \mathrm{~m}$ ) in thickness (Burckhardt, 1927, 1930, p. 24-35, 98-100; Guzmán Jiménez, 1950; Salas, 1949; Erben, $1956 \mathrm{a}$, p. $107-124$; 1956b, p. 18-34, 51-121; 1957a, p. 48-51). Marine Lower Jurassic beds are not present except possibly at one place in Guerrero (Erben, 1954, p. 4-12). Coal-bearing and nonmarine clastic beds are dated by plant taxa and stratigraphic positions as Toarcian to early middle Bajocian and middle Bathonian. Marine limestone, shale, and sandstone between the nonmarine units are dated by ammonite genera as late middle $\mathrm{Ba}-$ jocian to early Bathonian. Above the highest coal-bearing beds are marine limestone and marl dated by ammonite genera as late Bathonian to late Callovian. Gradationally above are other limestone and marl beds, which have not furnished ammonites but which are dated as Oxfordian because they contain species of pelecypods, gastropods, and echinoderms similar to and in part identical with species in the Zuloaga Limestone of northern Mexico. Younger Jurassic beds are represented definitely only by single occurrences of the ammonites $I d o$ ceras and Substeueroceras in western Oaxaca (Erben, 1957a, p. 51). These Jurassic sequences could represent an embayment directly from the south (Guerrero embayment), as suggested by Erben (1957b, p. 36-41), or from the southwest (Balsas Portal), as suggested by Lopez Ramos (1974, p. 385-391, 395-397), or from both directions.

In western Sonora, only parts of the Lower and Upper Jurassic have been identified faunally. Pelecypods of Sinemurian and possibly Hettangian Age have been obtained at several places from shale, shaly sandstone, and shaly limestone at least 2,500 feet $(762 \mathrm{~m})$ thick in the upper part of the Barranca Formation (Burckhardt, 1930, p. 23, 24, 41, 42; Jaworski, 1929; King, 1939, p. 16551659, pl. 5; Wilson and Rocha, 1949, p. 23-29). An early Sinemurian Age is confirmed by the presence of the ammonite Arnioceras near El Antimonio, about 30 miles (48 km) west of Caborca (Imlay, 1952a, p. 973), and Arietites in the Sierra de Santa Rosa, about 30 miles (48 $\mathrm{km}$ ) west of Puerto (Burckhardt, 1930, p. 23). A late Sinemurian Age is indicated by the presence of Crucilobiceras in association with probable Aegasteroceras about 25 miles $(40 \mathrm{~km})$ south-southeast of Caborca (identified by Imlay, 1975, for L. T. Silver, California Inst. Technology). A late Oxfordian Age is shown by the presence of Dichotomosphinctes and Discophinctes in the Cucurpe area about 30 miles $(50 \mathrm{~km})$ southeast of Magdalena (identified by Imlay, 1975, for Claude Rangin, University of Sonora). The Kimmeridgian ammonites Amoeboceras and Idoceras have been found a little south of Caborca throughout nearly 600 feet $(183 \mathrm{~m})$ of calcareous, gray to brown shale that is interbedded with some gray sandy shale and sandstone (T. E. Stump, Univ. California at Davis, written commun., April 1973). The ammonite-bearing beds are 2,000-2,565 feet (610-782 m) above the base of a sequence that is more than 5,000 feet $(1,524$ $\mathrm{m})$ thick and that has otherwise not been dated. Presumably much more than Kimmeridgian time is involved.

\section{WESTERN NEVADA TO CENTRAL CALIFORNIA}

Jurassic marine rocks older than Tithonian that are now exposed in California and western Nevada have the following characteristies: (1) they generally contain a great deal of volcanic material; (2) they generally change lithologically within fairly short distances; (3) they attain tremendous thicknesses; (4) their major sites of deposition gradually shifted westward; and (5) they have not yielded any fossils of Bathonian Age.

These Jurassic rocks, according to W. R. Dickinson $(1962$, p. 1243-1247, 1253), were deposited in a eugeosyncline whose eastern margin extended northeastward through central Nevada, then northward through western Idaho and eastern Washington, and then northwestward in Canada. Within this eugeosyncline were deposited enormous quantities of andesitic material derived from numerous volcanoes and now preserved as marine lava flows, tuffs, breccia agglomerates, and as an important constituent of marine clastic sediments. Within this eugeosyncline were also deposited some sediments derived from pre-Jurassic volcanic or sedimentary rocks exposed as islands (W. R. Dickinson, 1962, fig. 1 on p. 1243; Dickinson and Vigrass, 1964, p. 1042-1043). As most of these sediments were derived locally from volcanic vents, rather than from landmasses east of the eugeosyncline, their lithic characteristics and thicknesses change markedly within short distances. Evidently, volcanoes were most common in easternmost California along or near the site of the Sierra Nevada but also occurred in adjoining northwestern Nevada and in northcentral California (Stanley, 1971, p. 474, 475; Stanley and others, 1971, fig. 2 on p. 12).

The Lower Jurassic beds in this area extend westward across western Nevada into eastern California slightly beyond the crest of the Sierra Nevada, extend northwestward into the Big Bend area of north-central California, and attain their greatest thickness in Nevada. Bajocian beds are similarly distributed but occur also in the Santa Ana Mountains southeast of Los Angeles and 
attain their greatest thickness in the Sierra Nevada. Bathonian rocks have not been identified faunally in $\mathrm{Ne}-$ vada or California but, if present, are most likely to be found at high altitudes in the Sierra Nevada. Callovian rocks are known mainly from the western and higher parts of the Sierra Nevada, where they attain apparent thicknesses of $6,000-8,000$ feet $(1,830-2,440 \mathrm{~m})$. Lowermost Callovian rocks are also found in the Santa Ana Mountains as part of a very thick sequence. Oxfordian rocks are known from the western part of the Sierra Nevada, from the Santa Monica Mountains just north of Los Angeles, and from the western part of the Klamath Mountains in northwest California. Tithonian rocks, although possibly present in the Sierra Nevada (Crickmay, 1933 b, p. 903), have been identified faunally in California only in the western part of the State from San Diego northward.

Most of the Jurassic sedimentary rocks of western Nevada are assigned to the Sunrise and Dunlap Formations of Early Jurassic age (Muller and Ferguson, 1939, p. 1611-1613; Silberling, 1959, p. 29-31; Silberling and Roberts, 1962, p. 9, 21, 29, 32; Silberling and Wallace, 1969 , p. 47). Of these, the Sunrise Formation ranges in thickness from 1,200 to 2,400 feet ( 366 to $732 \mathrm{~m}$ ); consists mostly of interbedded gray massive limestone, laminated dolomitic limestone, shale, and siltstone; includes tuff beds and some brown sandstone beds whose particles are of volcanic origin; and ranges in age at most places from earliest Hettangian to early or late Pliensbachian (Muller and Ferguson, 1939, p. 1610, 1611; Stanley, 1971, p. 458). Near Westgate, Nev., the Sunrise Formation also includes beds of Toarcian Age (Hallam, 1965, p. 1487, 1488).

The Dunlap Formation ranges in thickness from a featheredge to about 5,000 feet $(1,520 \mathrm{~m})$ and consists mainly of dark-red to reddish-brown crossbedded sandstone interbedded with some breccia, conglomerate, mudstone, and volcanic rock. The formation is overlain locally by volcanic rocks, generally intertongues basally with the Sunrise Formation, but in place rests unconformably on Triassic or older rocks. Its age is late Pliensbachian to Toarcian on the basis of the presence of the ammonite Harpoceras (Muller and Ferguson, 1939, p. 1621), stratigraphic position above the Sunrise Formation, and the presence of the pelecypod Plicatostylus, which in eastern Oregon occurs directly below beds of late Pliensbachian Age (Imlay, 1968, p. C6).

The Jurassic is also represented at one place in western Nevada by the Westgate Formation of Corvalán (1962; Hallam, 1965, p. 1487, 1488). This formation is 560 feet $(171 \mathrm{~m})$ thick, rests conformably on 1,200 feet $(366 \mathrm{~m})$ of the Sunrise Formation, consists of limestone and calcareous quartzose sandstone, and contains am- monite fragments suggestive of Sonninia dominans Buckman (Corvalań's loc. A-11) of early middle Bajocian Age.

The Jurassic sedimentary rocks of western Nevada, as interpreted by Stanley (1971, p. 467-475; Stanley and others, 1971 , p. 15-18), were not deposited in a eugeosyncline but in a miogeosyncline that extended to, or nearly to, the western boundary of the State, shown by the presence of (1) normal shallow-water marine carbonate rocks in both the Sunrise and Dunlap Formations; (2) quartz sandstone in the Dunlap and Westgate Formations that is nearly identical with that in the Navajo and Aztec Sandstones farther east; and (3) interbedded red mudstone and red laminated siltstone in the Dunlap Formation, which are suggestive of tidal-flat deposits. These rocks are interbedded, however, with some eruptive volcanic rocks and with locally derived clastic sediments, which are not typical of the miogeosyncline. Thick volcanic deposits characteristic of the eugeosyncline are found in Nevada, according to Stanley (1971, p. $455,474)$, only in Douglas County east of Lake Tahoe. Most Jurassic sequences of California east of the Coast Ranges and of the western part of the Klamath Mountains are characterized by much volcanic material and generally by facies changes within short distances. Such sequences occur in the Big Bend area of the eastern Klamath Mountains in north-central California (Diller, 1895 , p. 4; 1906, p. 5; Sanborn, 1960, p. 11-15; Irwin, 1966, p. 23), in the Santa Ana Mountains about 50 miles southeast of Los Angeles (Silberling and others, 1961; Imlay, 1963; 1964c), and at many places in the Sierra Nevada (Diller, 1892; Bateman and others, 1963; Bateman and Wahrhaftig, 1966, p. 113-115; Crickmay, 1933b; McMath, 1966, p. 181, 182; Clark and others, 1962, p. B19; Clark, 1964, p. 15-41, Lindgren, 1900; Lindgren and Turner, 1894; Turner, 1894; Turner and Ransome, 1897; Taliaferro, 1942; Eric and others, 1955; Rinehart and others, 1959). An exception consists of the nonvolcanic Boyden Cave pendant near the junction of the South and Middle Forks of Kings River in the southcentral Sierra Nevada, a little west of roof pendants consisting of metavolcanic rocks (Jones and Moore, 1973).

Jurassic sequences in the Sierra Nevada occur in three parallel northward-trending belts that occupy a synclinorium (Bateman and Wahrhaftig, 1966, 113-115). One belt in the eastern part of the Sierra extends for more than 150 miles $(240 \mathrm{~km})$ as roof pendants. These consist of metamorphosed volcanic rocks and graywacke, many thousands of feet thick, which have furnished a few poorly preserved Early Jurassic ammonites. Another Jurassic belt, just west of the crest of the Sierra, extends northward for nearly 90 miles $(145 \mathrm{~km})$ from lat. $39^{\circ} \mathrm{N}$. near Colfax to the Taylorsville area; it is dated by means 


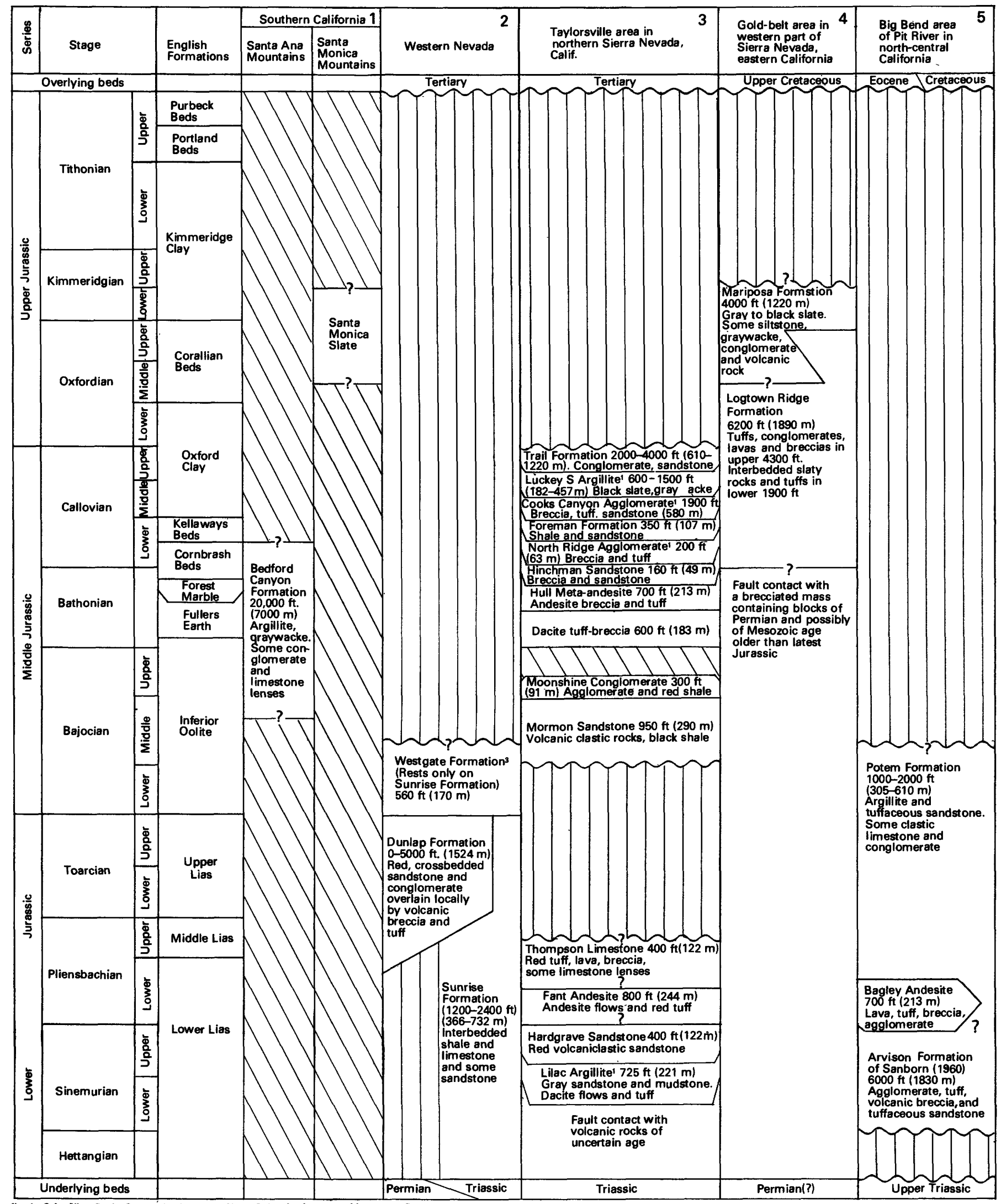

'Lucky S Argillite, Cooks Canyon Agglomerste, North Ridge Agglomerate, Moonshine Conglomerate,

and Liac Argillite of Crickmay (1933b) her ein adopted for U.S. Geological Survey usage.

Lonesome Formation and Trowbridge Shale of Lupher (1941) herein adopted for U.S. Geological

Westgate Formation of Corvalán (1962) herein adopted for U.S. Geological Survey usage. 


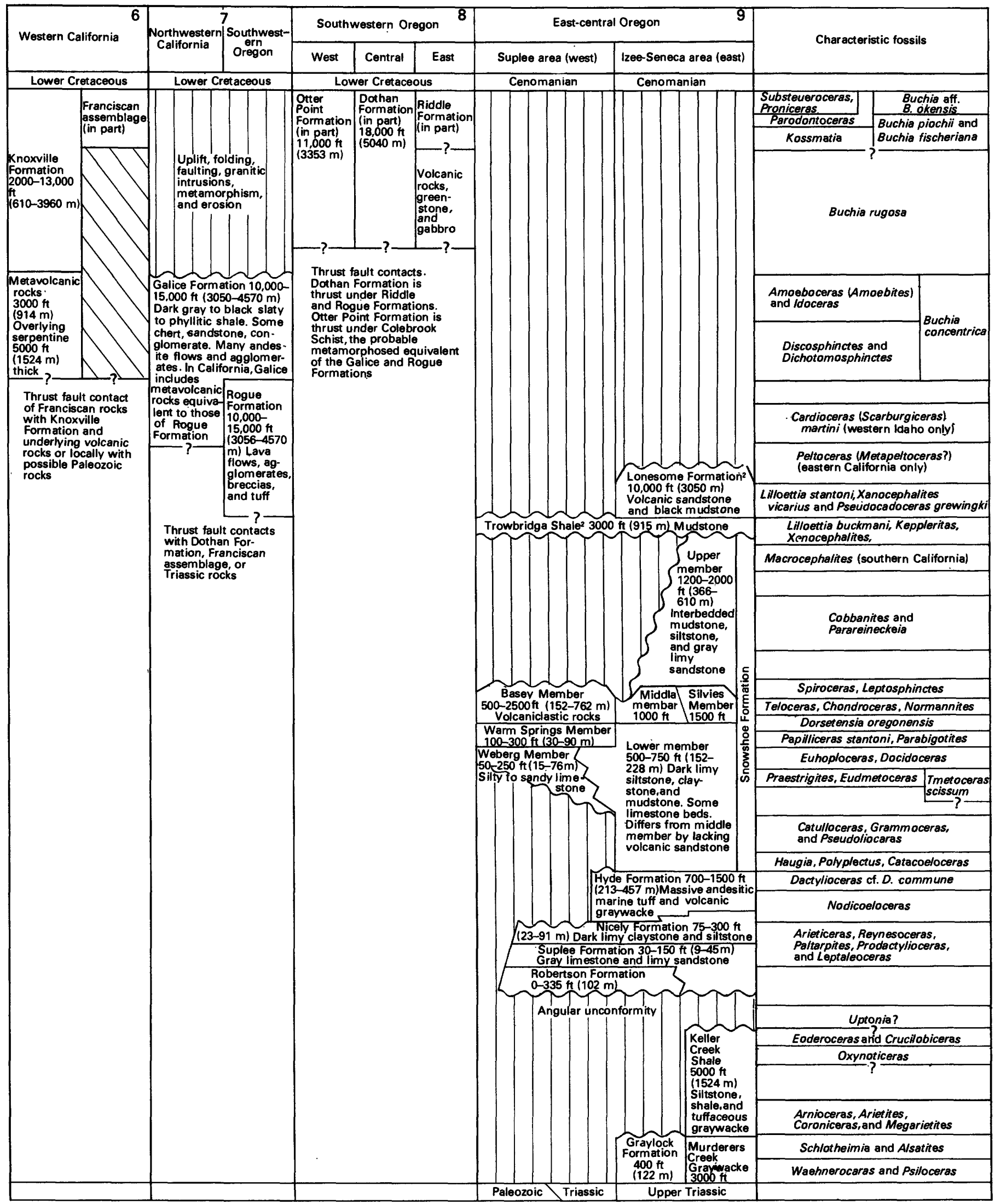

$B$. Western California to east-central Oregon.

FIGURE 22.-CORRELATIONS AND COMPARISONS OF JURASSIC ROCKS IN THE PACIFIC COAST REGION IN CALIFORNIA, NEVADA, AND WESTERN TO EAST-CENTRAL OREGON. Vertical lines indicate that strata are missing; diagonal lines indicate lack of fossil data; wavy lines indicate unconformity or disconfirmity; jagged lines indicate gradational or indefinite contact. Column numbers refer to locations shown on figure 18. 


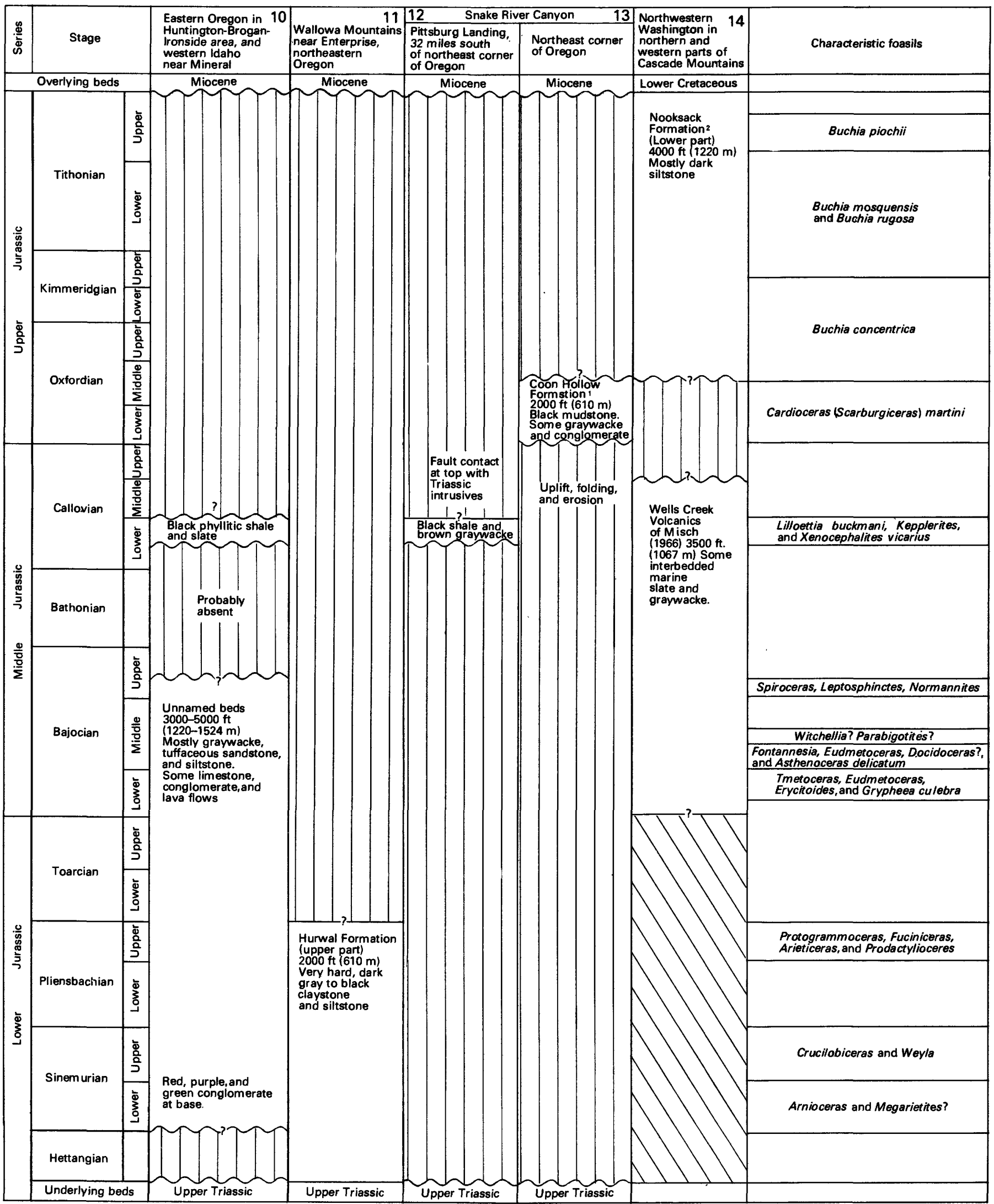

1Coon Hollow Formation of Morrison (1964) herein adopted for U.S. Geological Survey usage.

2Nooksack Formation of McKee and others (1956) herein adopted for U.S. Geological Survey usage.

FIgURE 23.-Correlations and comparisons of Jurassic rocks in the Pacific Coast region from eastern Oregon and western Idaho to northwestern Washington. Vertical lines indicate that strata are missing; diagonal lines indicate lack of fossil data; wavy lines indicate unconformity or disconformity. Column numbers refer to locations shown on figure 18. 
of ammonites as Sinemurian to Callovian. The third Jurassic belt extends along the western side of the Sierra Nevada for about 190 miles $(306 \mathrm{~km})$ from western Madera County northward to Butte County and contains ammonites of Callovian to early Kimmeridian Age.

Within these belts, the most complete Jurassic sequence is exposed in the middle belt in the upper parts of canyons on the west side and at the north end of the Sierra Nevada. The best section on the west side is exposed on the North Fork of the American River about 25 to 30 miles $(40-48 \mathrm{~km})$ east-northeast of Colfax, where it is called the Sailer Canyon Formation; it is at least 11,000 feet $(3,350 \mathrm{~m})$ thick and is possibly 20,000 feet $(6,100 \mathrm{~m})$ thick. The lower 10,000 feet $(3,000 \mathrm{~m})$ of this sequence, according to Clark and others (1962, p. B18B19), consists of graywacke, tuff, and dark-gray siltstone. Of this, the lower 500 to 700 feet $(150-210 \mathrm{~m})$ consists of tuff that rests unconformably on limestone of probable Late Triassic age. The Jurassic sequence, according to Taliaferro (1942, p. 100), consists of 12,800 feet $(3,900 \mathrm{~m})$ of conglomerate, sandstone, slaty shale, and andesitic tuff that is overlain by 9,500 feet $(2,900 \mathrm{~m})$ of volcanic rocks, lava flows, agglomerates, and tuffs. He reports Early Jurassic fossils 2,500 feet $(760 \mathrm{~m})$ above the base and Middle Jurassic fossils 9,500 feet $(2,900 \mathrm{~m})$ above the base. Fossils collected by geologists of the U.S. Geological Survey include Crucilobiceras of late Sinemurian Age, about 800-1,000 feet (240-300 m) above the base of the Sailor Canyon Formation (Clark and others, 1962, p. B19); Arieticeras and Reynesoceras of late Pliensbachian Age, about 2,000 feet $(610 \mathrm{~m})$ above the base (Imlay, 1968, p. C16, C17); and Tmetoceras of early Bajocian Age, about 8,500-11,000 feet (2,590-3,350 m) above the base (Imlay, 1973, p. 35).

The best known Jurassic sequence in the middle belt is exposed near Taylorsville at the northern end of the Sierra Nevada. The sequence was originally described by Diller $(1892$; 1908 , p. 34-60) and dated by Hyatt (1892, p. $400-412)$. It was later revised by Crickmay (1933b, p. 896-903), who proposed a number of new formation names. Still later, it was studied by McMath (1966, p. 181-183), who confirmed most of the stratigraphic succession and most of the formational names advocated by Crickmay. McMath was not able, however, to find the "Combe Formation," which was reported by Crickmay (1933b, p. 903) to contain Aulacosphinctoides of early Tithonian Age. The sequence as modified by McMath is shown in figure 22.

The Jurassic sequence exposed on Mount Jura near Taylorsville (fig. 22) has furnished fossils of Sinemurian to Callovian Age exclusive of the Bathonian. At the base, the Lilac Argillite of Crickmay (1933b, p. 896-897) contains the ammonite Echioceras of late Sinemurian Age in association with Weyla alata (von Buch) (Muller and Ferguson, 1939, p. 1613), which was described by Crick- may (1933b, p. 905, pl. 25, figs. 4-6) as Parapecten praecursor and ranges from upper Sinemurian to basal Toarcian, according to S. W. Muller (oral commun., 1958). The overlying Hardgrave Sandstone is probably only slightly younger, as it also contains Weyla alata (von Buch) ( = Parapecten acutiplicatus Meek in Crickmay, $1933 \mathrm{~b}$, p. 906, pl. 25, figs. 1-3). The next higher formation, the Fant Andesite, is assigned to the early Pliensbachian solely on the basis of stratigraphic position beneath beds of probable middle to late Pliensbachian Age.

The overlying Thompson Limestone is provisionally assigned a Pliensbachian Age because some gray limestone lentils within the formation contain the pelecypod Plicatostylus. That genus has been found elsewhere in beds of that age in eastern Oregon (Lupher and Packard, 1930; Lupher, 1941, p. 239; Dickinson and Vigrass, 1965, p. 36, 37) and in western Nevada (Muller and Ferguson, 1939, p. 1621, table 3; Silberling, 1959, p. 27). It has also been found in Chile in a sequence dated by means of ammonites as early Toarcian (Hillebrandt, 1973, p. 168, $175,193,195)$. Presence of this genus in the Thompson Limestone was first recognized by Bruce Batton and David Taylor, geology students from the University of Oregon at Eugene and the University of California at Berkeley, respectively, while doing fieldwork with the writer in 1975. Previous assignments of that limestone to the early Bajocian were based on the presence of the gastropod Nerinea, which in Europe is not known in preBajocian beds (Alpheus Hyatt, cited in Diller, 1908, p. 44). That age assignment, however, is not valid for the Pacific Coast region of North America, because Nerinea occurs in abundance in the Pliensbachian Robertson Formation of eastern Oregon (Dickinson and Vigrass, 1965, p. 36; Hallam, 1965, p. 1496).

The Bajocian is definitely represented by the Mormon Sandstone and by the Moonshine Conglomerate. The Mormon Sandstone contains species of the ammonites Sonninia, S. (Papilliceras), Normannites, and Stephanoceras (Crickmay, 1933b, p. 898, 899, 908-913) that furnish a correlation with the European Otoites sauzei zone and with the Oregon Warm Springs Member of the Snowshoe Formation, as discussed hy Imlay (1973, p. 34,35$)$.

In addition, the report of Teloceras near the top of the Mormon Sandstone (Crickmay, 1933b, p. 898) suggests a correlation with the European zone of Stephanoceras humphriesianum. Furthermore, the lower 75 feet $(23 \mathrm{~m})$ of the Mormon Sandstone on the south side of Mount Jura contains specimens of Euhoploceras (D. G. Taylor, written commun., 1976), which in Europe are characteristic of the lower middle Bajocian (Sonninia sowerbyi zone) but also occur at the top of the lower Bajocian (Graphoceras concavum zone) (Parsons, 1974, p. 170). 


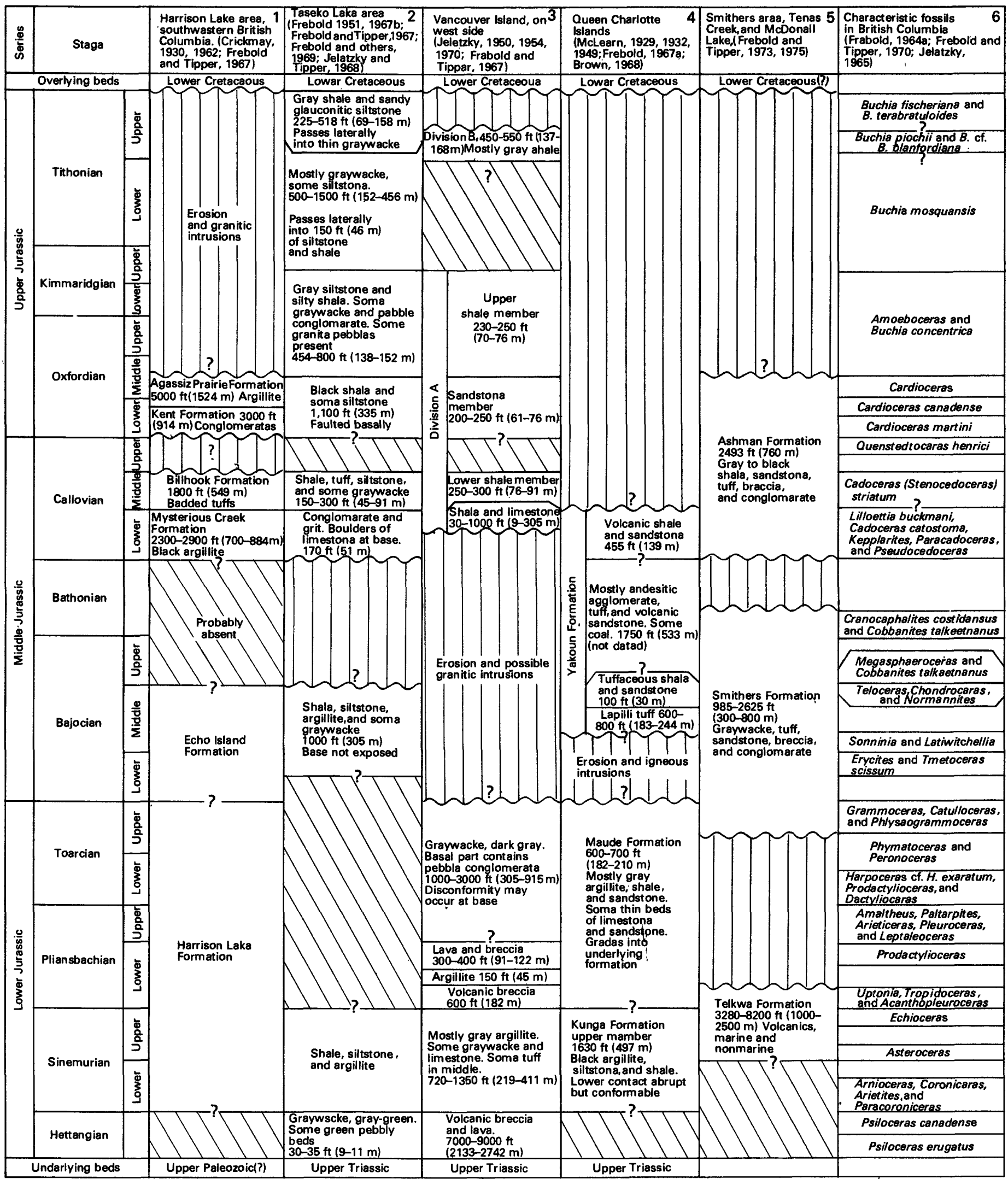

A. Southwestern to central British Columbia. 


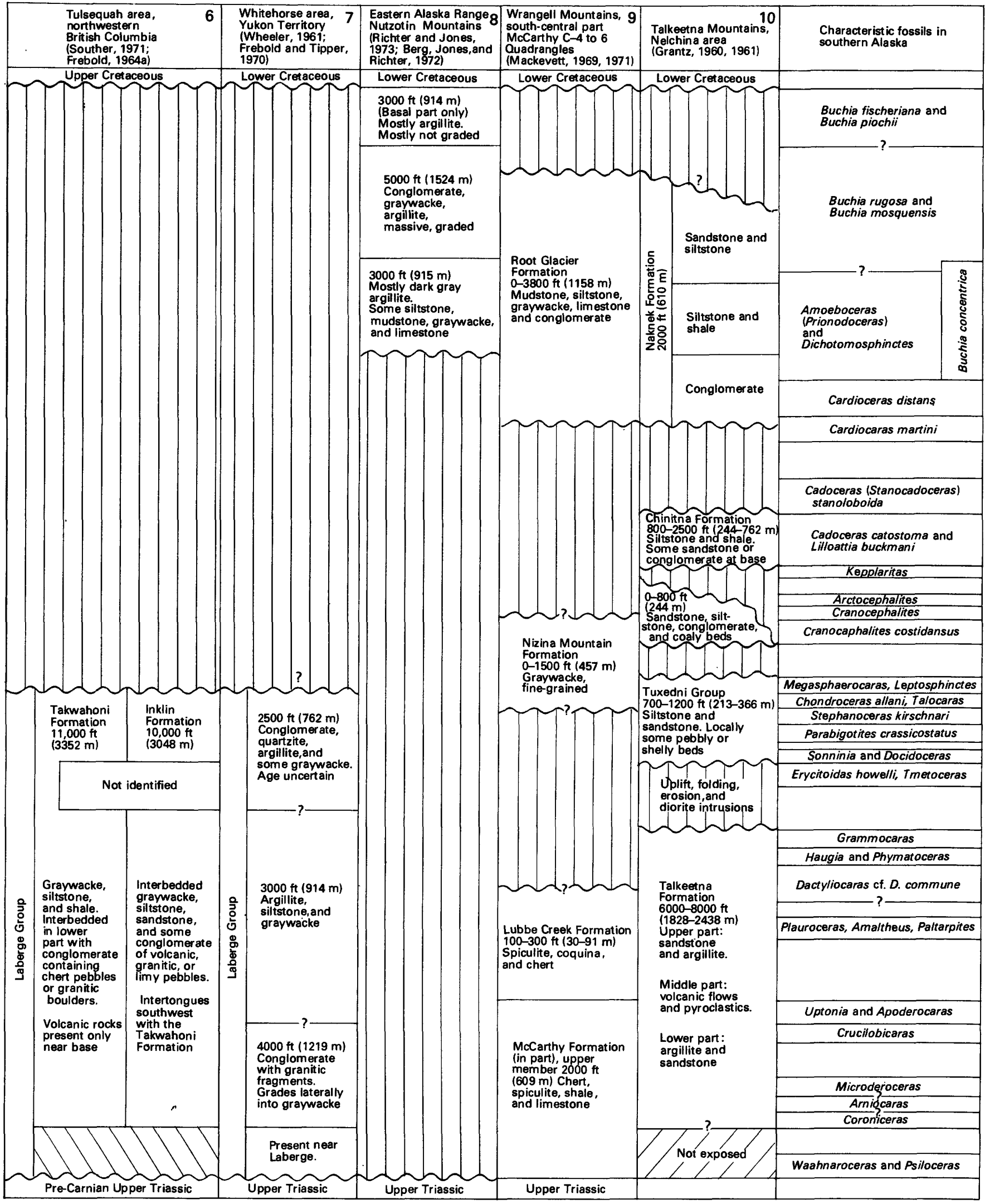

B. Northwestern British Columbia to southern Alaska.

FIGURE 24.-CORRELATIONS AND COMPARISONS OF JURASSIC ROCKS IN THE PACIFIC COAST REGION IN BRITISH COLUMBIA, YUKON TERRITORY, AND SOUTHERN ALASKA. Vertical lines indicate that strata are missing; right diagonal lines indicate strata not exposed; left-diagonal lines indicate lack of fossil data; wavy lines indicate unconformity or disconformity. Column numbers refer to locations shown on figure 19. 
The overlying Moonshine Conglomerate is dated as early late Bajocian because it contains several fragments of loosely coiled ammonites (USGS Mesozoic loc. 27322) belonging to the family Spiroceratidae and closely resembling specimens of Spiroceras bifurcatum (Quenstedt) from eastern Oregon (Imlay, 1973, pl. 1, figs. 3-8).

Next higher in the Mount Jura Jurassic sequence is an unnamed dacite tuff of MeMath (1966, p. 182), which is overlain by the Hull Meta-andesite. These units have not furnished fossils but could represent any time between latest Bajocian and earliest Callovian. They are herein provisionally assigned a Bathonian Age mainly on the basis of stratigraphic positions but partly because the early Callovian appears to be accounted for by the overlying formations.

The lower to middle Callovian is represented on Mount Jura by ammonites from the Hinchman Sandstone, the North Ridge Agglomerate, and the Foreman Formation (Imlay, 1961, p. D9). The next three overlying formations have not furnished any identifiable fossils and could be in part younger than Callovian. They are herein provisionally assigned to the Callovian because the thickness of the sequence from the Hinchman Sandstone to the Trail Formation is not much greater than that of the Logtown Ridge Formation in the western part of the Sierra Nevada and is much less than that of the Callovian beds in eastern Oregon.

Jurassic sequences exposed in the western part of the Sierra Nevada consist of partially metamorphosed sedimentary and voleanic rocks that differ from those exposed in the higher part of the Sierra in the following ways: (1) none is older than Callovian; (2) they are, in part, of early Oxfordian to early Kimmeridgian Age; (3) they are much more extensive; and (4) they contain more slaty beds. They have been divided into many formational units based generally on local lithologic and stratigraphic features (Turner, 1894, 1897; Lindgren, 1900; Lindgren and Turner, 1894; Becker, 1885, p. 18, 19; Taliaferro, 1942, p. 98, 99; 1943a, p. 282-284; Heyl and Eric, 1948, p. 51-53; Eric and others, 1955, p. 10-12; Imlay, 1961, p. D2-D9; Clark, 1964, p. 15-41; Sharp and Duffield, 1973, p. 3971-3974). Apparently most formational boundaries have been difficult to trace laterally because of complicated and extensive faulting, lithologic changes laterally within short distances, and scareity of fossils.

Thus, the sequence exposed in a central fault block near the Cosumnes River (Clark, 1964, p. 17-21, 2326 , pl. 9) was dated by Imlay (1961, p. D3-D8) as Callovian to early Kimmeridgian. Within this age span, the Mariposa Formation was dated as late Oxfordian to early Kimmeridgian on the basis of the presence of the ammonites Discosphinctes, Dichotomosphinctes, and Amoebo- ceras (Amoebites), in association with the pelecypod Buchia concentrica (Sowerby). The underlying Logtown Ridge Formation was dated as late early Callovian to late Oxfordian on the basis of the presence of Pseudocadoceras in its lower 600 feet $(180 \mathrm{~m})$ and Idoceras ef. $I$. planula (Heyl) near its top. The underlying "Cosumnes Formation" (of former usage) was dated as early Callovian because of its gradational relationship with the Logtown Ridge Formation. Subsequent studies by Sharp and Duffield (1973, p. 3971-3974; Duffield and Sharp, 1975 , p. $1,5,8,22,29)$ showed, however, that the "Cosumnes Formation" is not a mappable unit, because it consists of scattered blocks of graywacke, clay slate, and conglomerate that are bounded by faults and are part of a melange. This melange is separated from the Logtown Ridge Formation by a major fault involving considerable displacement and brecciation of beds. The melange may involve beds of several ages but is not younger than Late Jurassic, because it bears foliation that predates intrusions of Upper Jurassic granitic rocks.

Marked lateral variation within the Jurassic beds of the central fault block has been demonstrated by Clark (1964, p. 22, 23, pl. 9), who showed that the Logtown Ridge Formation passes southward near the Merced River into at least 15,000 feet $(4,570 \mathrm{~m})$ of voleanic rocks called the Peñon Blaneo Volcanies. Also, the Mariposa Formation locally contains thick volcanic members that consist mostly of breccia.

The Jurassic rocks exposed in a western fault block have been described by Clark (1964, p. 27-33) under formational names different from those used for the central block. These rocks are called, from youngest to oldest, the Copper Hill Volcanics, the Salt Spring Slate, and the Gopher Ridge Volcanies, Of these, the Salt Spring Slate resembles the slaty part of the Mariposa Formation, has been mapped previously under that name (see list of names in Clark, 1964, p. 29), and contains Buchia concentrica (Sowerby), a fossil common in the Mariposa Formation (see Imlay, 1961, p. D14). Presumably the Gopher Ridge Voleanies is roughly equivalent to the Logtown Ridge Formation, and the Copper Hill Volcanies, to the upper part of the Mariposa Formation.

In comparison with the Jurassic sequence near Taylorsville, the lower part of the Logtown Ridge, which contains Pseudocadoceras grewingki (Pompeckji), is correlated with the Foreman Formation. The lowest part of the Logtown Ridge Formation, which was separated from the "Cosumnes Formation" by Sharp and Duffield $(1973$, p. 3971,3972$)$ should be equivalent to the Hinchman Sandstone and the North Ridge Agglomerate. The middle to upper parts of the Logtown Ridge Formation are possibly equivalent to some or all of the three uppermost Jurassic formations near Taylorsville (see fig. 22). 
The Mariposa Formation may be correlated by the presence of Buchia concentrica (Sowerby) with the Santa Monica Slate just north of Los Angeles (Imlay, 1963, p. 103, pl. 14, figs. 14-19), with the Monte de Oro Formation exposed northeast of Oroville in Butte County, Calif., and with the Galice Formation in northwest California and adjoining parts of southwest Oregon. All these are characterized by dark-gray to black slaty to phyllitic beds that contain Buchia in places. Failure to find Buchia in slaty beds in the uppermost Jurassic formations near Taylorsville suggests that those formations are older than late Oxfordian.

Jurassic rocks older than Callovian occur at only two places in California outside the eastern and middle Jurassic belts in the Sierra Nevada. One of these is along the Pit River in the eastern Klamath Mountains about $30-40$ miles $(48-64 \mathrm{~km})$ northeast of Redding. It appears to be a northwestward extension of the Jurassic beds exposed near Taylorsville, although the two sequences are separated by about 75 miles $(121 \mathrm{~km})$ of volcanic rocks exposed at the south end of the Cascade Range. The other occurrence is in the Santa Ana Mountains southeast of Los Angeles. It could represent a southward extension of the metamorphosed Jurassic rocks of the central part of the Sierra Nevada, just as the Santa Monica Slate near Los Angeles could represent a southern extension of the Mariposa Formation of the western Sierra Nevada.

The Jurassic sequence exposed along the Pit River in north-central California is about 8,000 feet $(2,440 \mathrm{~m})$ thick. At its base is the Arvison Formation, which is about 6,000 feet $(1,830 \mathrm{~m})$ thick, consists mostly of volcanic flows, breccia, agglomerate, and tuff, and contains some conglomerate and tuffaceous sandstone. The Arvison rests unconformably on Triassic beds and at one place has yielded the Sinemurian ammonites Asteroceras and Arnioceras (Sanborn, 1960, p. 11-14). The overlying Potem Formation (Diller, 1906, p. 5), which is 1,000 2,000 feet $(305-610 \mathrm{~m})$ thick, passes laterally in its lower part into the Bagley Andesite. The Potem consists mostly of argillite and calcareous tuffaceous sandstone but includes some conglomerate and limestone lentils and apparently is conformable with the Arvison Formation of Sanborn $(1960$, p. 6, 14-16, pl. 1). The age of the lower part of the Potem Formation is definitely Early Jurassic, not younger than early Toarcian, as shown by the occurrence of Weyla aff. W. alata (von Buch) (S. W. Muller, oral commun., 1958). The age of the upper part is not older than late Toarcian, as shown by the occurrence of Bositra buchii (Romer) (Guillaume, 1928), and could be as young as Bajocian, according to Sanborn (1960, p. 16).

The Jurassic beds cropping out in the Santa Ana Mountains of southern California are all included in the
Bedford Canyon Formation, which consists mostly of dark-gray to black slates and argillite, includes some quartzite and fossiliferous limestone lentils, and is estimated to be 20,000 feet $(6,100 \mathrm{~m})$ thick (Larsen, 1948, p. 18-24; Engel, 1959, p. 16-25). Fossils from the limestone lentils were once considered to be of Triassic age (Engel, 1959, p. 22-24) but are now dated as Jurassic on the basis of ammonites (Silberling and others, 1961, p. $1746,1747)$. Thus, the pelecypod originally described as Daonella sanctea-anea Smith (Smith, 1914, p. 145) is now assigned to the genus Silberlingia (Imlay, 1963, p. 100) and dated as early Callovian because it occurs with Macrocephalites and Hecticoceras (Imlay, 1963, p. 98, 99, pl. 14, figs. 1-9, 26-36; 1964c, p. 506, 508, pl. 78, figs. 22-26). Also, some brachiopods that were once considered to be of Triassic age (G. A. Cooper, cited in Larsen, 1948, p. 18), were apparently collected at the same stratigraphic level as some middle Bajocian ammonites identified as Dorsetensia and Teloceras? sp. juv. (Imlay, 1964c, p. 506-508, pl. 78, figs. 3-18).

\section{WESTERN CALIFORNIA AND SOUTHWESTERN OREGON}

Jurassic marine sequences exposed in and near the Coast Ranges in California and in the western Klamath Mountains in northwest California and southwest Oregon have the following characteristics, geologic relationships, and historical developments:

1. They are entirely of Late Middle to Late Jurassic age (Callovian and younger).

2. They are generally many thousands of feet thick.

3. They include sequences of two or three different age ranges that are associated only in the western Klamath Mountains and are therein separated by thrust faults.

4. Some sequences are of Callovian to early Kimmeridgian Age; contain a great deal of volcanic material; were deposited in deep to fairly deep waters, on the basis of lithologic characteristics; were uplifted, folded, metamorphosed, intruded, and eroded during late Kimmeridgian to Tithonian time; and were then overlain unconformably in places by shallow-water marine Cretaceous beds. These sequences include the Logtown Ridge-Mariposa sequence in the Sierra Nevada and the Rogue-Galice sequence in the Klamath Mountains.

5. Other sequences are of late Kimmeridgian to late Tithonian Age; are mostly nonvolcanic; originated in shallow to fairly shallow water, on the basis of fossils and lithologic features; and pass conformably upward into shallow-water marine sediments 
of earliest Cretaceous age. They include the Knoxville Formation of California and possibly the Riddle Formation of Oregon, although the last named has not furnished fossils older than the late Tithonian. They are underlain by unfossiliferous metavolcanic rocks that, on the basis of stratigraphic position, should be at least of early Kimmeridgian and Oxfordian Age.

6. Still other sequences are only of late Tithonian Age, are volcanic, pass conformably upward into beds of earliest Cretaceous age, and appear to be of fairly deep to deep-water origin, on the basis of lithologic features. They include the Dothan Formation and most of the Otter Point Formation of Oregon and the Franciscan assemblage of California.

7. The sequences of Callovian to early Kimmeridgian Age were deposited in different areas from those of later Jurassic age and are now juxtaposed in the Klamath Mountains by eastward underthrusting of the younger sequence.

In the Dayville-Riddle area of southwestern Oregon, the slaty Galice Formation overlies the metavolcanic Rogue Formation. These rocks crop out in an arcuate belt $10-30$ miles $(16-48 \mathrm{~km})$ wide that extends about 190 miles $(306 \mathrm{~km})$ south into southern Trinity County in northwest California, where they are all included in the Galice Formation. The Galice ranges from Oxfordian to early Kimmeridgian time. Along the west side of the belt, these rocks are in contact with the Josephine ultramafic mass, the South Fork Mountain Schist, and the Dothan Formation. Along the east side, they are in fault contact with upper Paleozoic rocks in California and Triassic(?) rocks in Oregon (Diller, 1907, p. 403; Wells and others, 1949, p. 47; Cater and Wells, 1953, p. 84; Wells and Walker, 1953; Irwin, 1960, p. 27, 28; Dott, 1971 , p. 9, 10; Beaulieu, 1971, p. 3, 15, 19, 20, 38). Thicknesses cannot be measured owing to intense crumpling, faulting, and intrusions, but estimates range from 10,000 to 30,000 feet $(3,050$ to $9,140 \mathrm{~m})$ (Irwin, 1960, p. 27).

At the top of the Galice Formation, a normal sedimentary contact, instead of a faulted contact, has only been found near the Oregon coast on Barklow Mountain in northwestern Curry County. On that mountain, the formation is overlain unconformably by a conglomerate that contains Buchia pacifica Jeletzky (USGS Mesozoic loc. M5006) of early to middle Valanginian Age (Dott, 1966 , p. $94 ; 1971$, p. 11). This relationship, plus the fact that no Upper Jurassic beds have yet been found above the Galice Formation or the equivalent Mariposa Formation, suggests that both these formations were above sea level and that they provided sediment during deposition of the Knoxville Formation and the older part of the Franciscan rock assemblage (Bailey and others, 1964 , p. 126, 146, 147).
The Galice Formation is correlated with the Mariposa Formation of the western Sierra Nevada because it is strikingly similiar lithologically and likewise contains the pelecypod Buchia concentrica (Sowerby) and the ammonite Perisphinctes (Dichotomosphinctes) (Imlay, 1961, p. D10). The underlying Rogue Formation, which apparently is gradational with the Galice, consists of many kinds of volcanic rocks similar to those in the Logtown Ridge Formation of the western Sierra Nevada. It may be of the same age, but to date it has not yielded any fossils. These facts show that the Galice Formation is a northward extension of the Mariposa Formation and was deposited under the same environmental conditions. Similarly, the Rogue Formation may be the northern extension of the Logtown Ridge Formation, but the Rogue was deposited under somewhat different environmental conditions, as shown by its lack of some ammonites that are present throughout the Logtown Ridge Formation.

Upper Tithonian beds crop out in the Coast Ranges of western California as far south as San Diego, in the Klamath Mountains of northwestern California, and in southwestern Oregon (fig. 22). In California, they occur in the Franciscan rock assemblage and in the Knoxville Formation (Taliaferro, 1943b). In Oregon, they occur in the Otter Point, Dothan (Taliaferro, 1943b), and Riddle Formations.

Among these rock units, the Franciscan assemblage and the Dothan and Otter Point Formations closely resemble each other. The Franciscan consists mostly of graywacke but includes some dark shale, altered volcanic rock (greenstone), chert, limestone, and blue schist and is estimated to be at least 50,000 feet $(15,240 \mathrm{~m})$ thick (Bailey and others, 1964, p. 5, 20-122). The Dothan consists mostly of massive hard graywacke but includes black mudstone, chert, and conglomerate. It is estimated to be at least 18,000 feet $(5,490 \mathrm{~m})$ thick and passes southward into the Franciscan assemblage in California (Beaulieu, 1971, p. 15; Dott, 1971, p. 43-46; Wells and Walker, 1953). The Otter Point consists of graywacke, black mudstone, argillite, altered volcanic breccias and flows (greenstone), much conglomerate, 2 chert, and some limestone lentils and appears to be thousands of feet thick (Koch, 1966, p. 36-43; Beaulieu, 1971, p. 30; Dott, 1971, p. 27-31). It greatly resembles the Dothan Formation but is distinguished lithologically by being darker and more sheared, by containing more volcanic fragments, pillow lavas, and fossils, and by its graywacke being less indurated (Dott, 1971, p. 46). All contacts of these formations are marked by thrust faults.

Resemblances between the Knoxville and Riddle Formations are not nearly as close as those among the three formations just described. The Knoxville Formation consists of gray shale, siltstone, thin-bedded sandstone, conglomerate lenses, and some limestone concretions in shale units and is $2,000-13,000$ feet $(610-3,960$ $\mathrm{m})$ thick. The Riddle Formation consists of gray silt- 
stone, thin-bedded graywacke, lenses of conglomerate, and some limestone lentils and is at least 1,100 feet (335 m) thick. Most of that thickness, however, involves beds of Berriasian Age, which are younger than any part of the Knoxville Formation as now defined. Comparisons between the two formations are difficult to make because the Riddle Formation is much broken by faults and has not been studied as thoroughly as the Knoxville Formation.

On the basis of fossils, the Franciscan assemblage is dated as late Tithonian to Turonian and possibly Campanian (Bailey and others, 1964, p. 115-122, table 16). A late Tithonian Age is based mainly on four occurrences of Buchia piochii (Gabb) in the northern Coast Ranges, including one at the south end of Lake Pillsbury. This age is supported by the occurrence of $B$. piochii with $A u$ lacosphinctes? sp. juv. near Stanley Mountain in the southern Coast Ranges.

The upper part of the Knoxville Formation is dated as late Tithonian on the basis of both ammonites and buchias at many levels, as recently documented in detail (Bailey and others, 1964, p. 124-130; Jones and others, 1969 , p. A9-A12; Imlay and Jones, 1970 , p. B5-B12, $\mathrm{B} 17-\mathrm{B} 19)$. The lower part is dated as late Kimmeridgian to early Tithonian by the presence of Buchia rugosa (Fischer) about 50-100 feet (15-30 m) above the base of the formation in the Paskenta area (Jones, 1975). Assignment to the late Kimmeridgian is also favored by the presence of a few specimens that bear very fine ribs, as on $B$. concentrica (Sowerby), and by the absence of $B$. mosquensis (von Buch) (D. L. Jones, oral commun., 1975), an associate of $B$. rugosa, which becomes more common upward. This occurrence does not imply that the basal part of the Knoxville Formation is of late Kimmeridgian Age throughout its extent.

A late Tithonian Age for the Otter Point Formation in southwestern Oregon is proven by the presence of Buchia piochii (Gabb) at many localities (Koch, 1966, p. 42, 43). However, a Berriasian Age for part of the formation is shown by the presence of many specimens of B. uncitoides (Pavlow) (USGS Mesozoic loc. 2074) in association with the ammonite Neocosmoceras, a genus that is much more common in Berriasian than in Tithonian beds. With these occur one immature specimen of Proniceras and a few specimens of $B$. piochii (Gabb), both of which are good evidence of a late Tithonian Age and both of which have a different colored matrix from the specimens of Neocosmoceras and B. uncitoides. Therefore, the fossils were probably collected from different beds of different ages (Imlay and Jones, 1970, p. B5, B32, B51, B52).

A late Tithonian Age for part of the Dothan Formation is proven only by the occurrence of Buchia piochii (Gabb) at one place on the Chetco River in Curry County, Oreg. (Ramp, 1969, p. 245). The probability that the formation is partly of younger age is suggested by its great thickness and by its close lithologic similarities to the Otter Point Formation and to the Franciscan assemblage, both of which have yielded fossils younger than Tithonian.

The Riddle Formation is definitely of Tithonian to Berriasian Age in its type section near Days Creek, Oreg. Buchia fischeriana (Keyserling) and Aulacosphinctes of late Tithonian Age occur just above the basal conglomerate. B. uncitoides (Pavlow) of Berriasian Age occurs from 20 to 1,004 feet ( 6 to $306 \mathrm{~m}$ ) above the basal conglomerate (Imlay and others, 1959, p. 2775-2778; Imlay and Jones, 1970, p. B13, B17). The late Tithonian Age for the lower part of the Riddle Formation is confirmed by the presence of $B$. fischeriana with Proniceras on Cow Creek near the mouth of Iron Mountain Creek in the NE1/4 sec. 4, T. 31 S., R. 7 W., Dutchman Butte Quadrangle, Douglas County, Oreg. In addition, the ammonite Durangites, obtained from a limestone lentil in the Dillard area south of Roseburg, Oreg. (Imlay and others, 1959 , p. 2778 ; Imlay, 1960 , p. 169 , pl. 31, figs. 11,12 ), could be from either the Riddle or the Dothan Formation.

\section{EASTERN OREGON AND WESTERN IDAHO}

The stratigraphic and lithologic features and correlations of the Jurassic formations exposed in an inlier in Tertiary volcanic rocks south and southwest of John Day, Oreg. have been described in considerable detail. (Lupher, 1941; Dickinson and Vigrass, 1965, p. 30-64; Buddenhagen, 1967; Brown and Thayer, 1966a, b; Imlay, 1964a, p. D2-D9; 1968, p. C4-C21; 1973, p. 8-25) and are summarized on figure 22 . As a whole, the Jurassic sequences in that inlier are characterized by enormous thicknesses, by rapid facies changes, and by consisting mostly of volcanic ejecta, flows, and breccias. They also include some sedimentary material that was derived mostly from a landmass to the west where Triassic and Paleozoic rocks were exposed but that was derived in part from a landmass to the north where only Triassic rocks were exposed.

Overall thicknesses of the Jurassic sequences range from about 1,800 feet $(550 \mathrm{~m})$ on the west to about 24,000 feet $(7,300 \mathrm{~m})$ on the east. Lower Jurassic beds thicken eastward from about 400 to 1,600 feet (120 to $490 \mathrm{~m}$ ), to which may be added about 8,000 feet $(2,400 \mathrm{~m})$ of Hettangian and Sinemurian beds exposed in the northeastern part of the Izee Quadrangle, the northern parts of the Logdell and Seneca Quadrangles, and the southern part of the Mount Vernon Quadrangle. Bajocian and Bathonian beds vary in thickness from about 1,800 to 2,750 feet ( 550 to $838 \mathrm{~m}$ ) and are thinnest in the central part of the inlier. Callovian beds vary in thickness from about 1,000 feet $(300 \mathrm{~m})$ on the west to about 14,000 feet $(4,300 \mathrm{~m})$ on the east. 
These variations in thickness are related to nearness to volcanic sources, to positions relative to land areas, upwarps, and basins, and to the presence and extent of unconformities (Dickinson and Vigrass, 1965, pl. 3). Widespread angular unconformities, involving intense folding, some faulting, erosion, and changes in direction of folding, developed in early Pliensbachian time (Brown and Thayer, 1966a, b) and after middle Callovian time. A local unconformity involving folding, uplift, and erosion developed in the Suplee area in Toarcian to early Bajocian (Aalenian) time. Another unconformity, involving some warping and erosion, formed in the Suplee-Izee area between deposition of the Snowshoe Formation and the Trowbridge Shale but within beds of early Callovian Age, according to Dickinson and Vigrass (1965, p. 83, pl. $3)$. Nonetheless, the presence of the early Callovian ammonites Iniskinites and Lilloettia 300-500 feet (90-150 $m$ ) below the top of the upper member of the Snowshoe Formation suggests that the exact stratigraphic position and age of the unconformity needs confirmation.

The fact that the Suplee Formation of late Pliensbachian Age rests on the Graylock Formation of Hettangian Age at one place and on the much thicker Keller Creek Shale of early to late Sinemurian Age only 6 miles $(9.6 \mathrm{~km})$ away suggests considerable erosion locally during early Pliensbachian time. It is not proof, however, because the two occurrences are separated by a major fault of unknown displacement. Before faulting they could have been much farther apart, could have been parts of different structural plates, and could have had a different sedimentary history. Perhaps the best evidence for erosion is the presence of an angular unconformity between the Keller Creek and Suplee Formations (Brown and Thayer, 1966a). This unconformity is well exposed on a road near fossil locality D66 (Dickinson and Vigrass, 1965. pl. 1) in the $\mathrm{NE}^{1 / 4} \mathrm{NE}^{1 / 4}$ sec. 2, T. 17 S., R. 28 E., in the Izee Quadrangle.

Beds of early Sinemurian to early late Bajocian Age and of possible Callovian Age are present in southern Baker County and northern Malheur County in east-central Oregon (fig. 23) from the Snake River westward at least 50 miles $(80 \mathrm{~km})$. Beds of early Callovian Age and of probable older Jurassic age are present nearby, east of the Snake River near the abandoned mining town of Mineral, Idaho.

From Juniper Mountain, about 10 miles $(16 \mathrm{~km})$ west-southwest of Brogan, Oreg., the eastern (lowermost) boundary of the Jurassic extends northeastward about 25 miles $(40 \mathrm{~km})$, crosses the Snake River about 64 miles $(104 \mathrm{~km})$ north-northeast of Huntington, and continues another 10 miles $(16 \mathrm{~km})$ in Idaho to Dennett Creek, where it curves eastward just south of the old mining town of Mineral (abandoned).
The lower boundary of the Jurassic in the Huntington area, Oregon, is marked by $30-800$ feet $(9-240 \mathrm{~m})$ of red, purple, and green conglomerate that rests unconformably on Upper Triassic beds (Brooks, 1967, p. 114118) and consists of clasts derived from those beds. These clasts are typically compressed and sheared except for certain discontinuous rock bodies of late Pliensbachian Age that occur in the lower part of the conglomerate. Within these bodies, such fossils as ammonites, pelecypods, and corals occur in thin calcareous graywacke that is associated with mostly round, nonsheared clasts that are a peculiar dark green (H. C. Brooks, written commun., April 1974). In the Mineral area, Idaho, similar coarse conglomerate beds grade downward into tuffs that overlie a quartz diorite sill (Livingston, 1932, p. 33). In the Juniper Mountain area of Oregon, the lower boundary is marked by a thin unit of reddish sandstone and shale that rests on massive limestone of possible Early Jurassic, Triassic, or late Paleozoic age.

The late Pliensbachian ammonites in the basal conglomerate are not proof that the conglomerate is of that age, because the conglomerate is overlain by graywacke that basally contains ammonites of early to late Sinemurian Age. It appears, therefore, that rock bodies of late Pliensbachian Age in the lower part of the conglomerate must have attained that position as a result of southeastward thrusting after Pliensbachian time or by deposition in channels or pockets that were cut into the conglomerate or into the Triassic beds during early Pliensbachian time. The possibility of erosion during that time is suggested by the lack of fossils of that age anywhere in eastern Oregon and by the fact that considerable erosion took place during early Pliensbachian time in the Suplee-Izee area farther west.

Above the basal conglomeratic unit in the Huntington area are some thousands of feet of beds that contain fossils of Sinemurian to early late Bajocian Age (fig. 23). This sequence consists mostly of sheared and slightly metamorphosed gray to yellowish-gray, green, brown or black massive to thin-bedded graywacke, tuffaceous sandstone and siltstone, but it also includes some beds of water-laid tuff, conglomerate, quartz sandstone, limestone, and lava flows.

Above the thin basal unit of reddish sandstone and shale in the Juniper Mountain area is at least 5,000 feet $(1,500 \mathrm{~m})$ of gray shale, siltstone, graywacke, and conglomerate (Wagner and others, 1963, p. 688). Within this sequence, the upper 2,000 feet $(600 \mathrm{~m})$ has been dated as early to early late Bajocian on the basis of ammonites (Imlay, 1973, p. 30), and the lower 3,000 feet $(900 \mathrm{~m})$ has been dated as Early Jurassic on the basis of stratigraphic position and the presence of Crucilobiceras? $75-100$ feet $(23-30 \mathrm{~m})$ above the base. 
In the Mineral area, Idaho, a coarse conglomerate unit is overlain by some 100 feet $(30 \mathrm{~m})$ or more of darkgray, sandy, thin- to medium-bedded tuff, which contains a species of Gryphaea (Imlay, 1964a, p. D13). This species has been found elsewhere about 64 miles $(104 \mathrm{~km})$ north-northwest of Brogan, Oreg., in association with the early Bajocian ammonites Tmetoceras and Erycitoides (USGS Mesozoic loc. 30142).

Still younger beds of early Callovian Age are exposed along Dennett Creek and its tributaries near Mineral, Idaho. These beds are probably several hundred feet thick and consist of dark-gray calcar ' 's shale that contains many black concretions (Livingstu1, .932, p. 33, 34; Imlay, 1964a, p. D3). From a few concretions have been obtained such ammonites as Lilloettia buckmani (Crickmay), Xenocephalites vicarius Imlay, and evolute Kepplerites apparently identical with $K$. snugharborense (Imlay) (1964a, p. D6, D7). This shale contains the same ammonites as the lithologically similar Trowbridge Shale in the Suplee-Izee area southwest of John Day, Oreg. (Lupher, 1941, p. 263; Dickinson and Vigrass, 1965, p. 60-64). Faunally, it correlates with the lower part of the Tonnie Siltstone Member of the Chinitna Formation in southern Alaska (Imlay, 1975, p. 3, 6, 14).

Similar dark-gray to black shale, slightly to strongly metamorphosed locally, occurs at several places in Baker and Malheur Counties, Oreg., above beds of late Bajocian Age. It is represented (1) in the northern part of the Huntington Quadrangle near Dixie Creek and farther northeast near Morgan, Hibbard, and Connor Creeks by thick, tightly folded, gray to black phyllite and slaty beds (Brooks, 1967, p. 118, location map on p. 114); (2) on the northern side of Juniper Mountain (T. 15 S., R. 41 E., secs. 30-32), southwest of Brogan, by 1,000 feet $(300 \mathrm{~m})$ or more of black phyllitic shale that contains limestone lentils and concretions (Wagner and others, 1963, location map on p. 689); and (3) by dark-gray to black slate and phyllitic shale exposed southwest of Ring Butte in the northeast part of T. 16 S., R. 37 E., in the Ironside Mountain Quadrangle (W. D. Lowry, unpub. data, 1968). No fossils have been found in any of these dark shales, phyllites, or slates in easternmost Oregon, but a Callovian Age for them is indicated by their lithologic resemblance to the Trowbridge Shale in the Suplee-Izee area and to the unnamed black shale near Mineral, Idaho, and by their superpositions on Bajocian beds.

Lower Jurassic beds are represented in the upper 2,000 feet $(600 \mathrm{~m})$ of the Hurwal Formation (Smith and Allen, 1941, p. 6, 13, 14) exposed in the Wallowa Mountains south of Enterprise in northeast Oregon. They consist of partially metamorphosed dark-gray to black claystone and siltstone that weathers brownish red and contains Sinemurian and Pliensbachian fossils (Imlay,
1968, p. C7, C15, C16). The most complete sequence is exposed in the northeast part of the mountains (NW1/4 $\mathrm{NW}^{1 / 4}$ sec. 19 (unsurveyed), T. 2 S., R. $44 \mathrm{E}$.), is 980 feet $(299 \mathrm{~m})$ thick, is covered by debris basally, and contains ammonites of late Sinemurian to late Pliensbachian Age. Elsewhere in the mountains, early Sinemurian ammonites are known at five places. At one of these places, near Twin Peaks (center of SW1/4 sec. 17, T. 3 S., R 44 E.), the beds of that age grade downward into unfossiliferous beds that, in turn, grade downward into Upper Triassic beds. On the basis of these occurrences, the thickness of the Pliensbachian beds is about 680 feet (207 $\mathrm{m}$ ), of the upper Sinemurian beds, at least 300 feet (90 $\mathrm{m})$, of the lower Sinemurian beds, 700-800 feet (210-240 $\mathrm{m})$, and of the beds of possible Hettangian Age, 200-300 feet $(60-90 \mathrm{~m})$.

Within the Lower Jurassic sequence exposed in the Wallowa Mountains, the early Sinemurian is represented by crushed and deformed ammonites of the family Arietitidae that probably include Coroniceras, Metophioceras, and Megarietites. The late Sinemurian is represented by Gleviceras, Crucilobiceras, Eoderoceras, Oxynoticeras?, Echioceras?, Coeloceras?, and Arctoasteroceras. The early Pliensbachian is either absent or is represented by 60 feet $(18 \mathrm{~m})$ of unfossiliferous beds. The late Pliensbachian is identified throughout about 620 feet $(189 \mathrm{~m})$ of beds by such genera as Canavaria, Harpoceras (Harpoceratoides), Arieticeras, Prodactylioceras, Protogrammoceras, and Fuciniceras. Fanninoceras was collected from the lower 350 feet $(107 \mathrm{~m})$ of these beds (USGS Mesozoic locs. 28809, 28810) in association with the ammonites listed.

This association of Fanninoceras with ammonite genera of late Pliensbachian Age is confirmed by a similar association in the Izee-Suplee area southwest of John Day, Oreg. In that area, Fanninoceras has been collected with Fuciniceras in concretions and beds in the upper third of the Suplee Formation (USGS Mesozoic loc. 29223) and with Leptaleoceras and Arieticeras, from a 6-inch (15-cm) layer about $15-20$ feet $(4.5-6 \mathrm{~m})$ above the base of the Nicely Formation (Lupher's loc. 125 in Imlay, 1968, p. C13, C15). Arieticeras, Paltarpites, and Lioceratoides are about 54 feet $(16.5 \mathrm{~m})$ above the base of the Nicely (USGS Mesozoic loc. 29218), and Leptaleoceras, Fuciniceras, Reynesoceras, and Arieticeras are about 20 feet $(6 \mathrm{~m})$ below the top of the Nicely (USGS Mesozoic loc. 27360). In that area, as well as in the Wallowa Mountains, Fanninoceras is associated with Prodactylioceras but not with Dactylioceras. The presence of Fanninoceras in beds of late Pliensbachian Age has recently been confirmed by Hans Frebold (written commun., 1975), who has found Fanninoceras associated with ammonites of early Pliensbachian to early Toarcian 
Age on Maude Island in the Queen Charlotte Islands of British Columbia.

The Jurassic is represented in the Snake River Canyon at Pittsburg Landing, about 32 miles $(52 \mathrm{~km})$ south of the northeast corner of Oregon, by at least several hundred feet of tightly folded soft black shale, darkbrown graywacke, and some limestone, which rests unconformably on Upper Triassic clastic rocks (Vallier, 1968, p. 247). An early to middle Callovian Age is shown by the presence of Lilloettia, Xenocephalites vicarius Imlay, and probable Grossouvria. Correlation with the Trowbridge Shale instead of the Lonesome Formation of the Suplee-Izee area of eastern Oregon is suggested by the absence of $P$ seudocadoceras.

Upper Jurassic beds that are lithologically and faunally distinct from any known elsewhere in Idaho and Oregon are exposed along both sides of the canyon of the Snake River for about 4 miles $(6.4 \mathrm{~km})$ just south of the northeast corner of Oregon (Morrison, 1961). These beds, named the Coon Hollow Formation by Morrison (1964), are about 2,000 feet $(610 \mathrm{~m})$ thick and consist mostly of hard, splintery, thin-bedded, black noncalcareous mudstone. They include also some beds of graywacke and chert-pebble conglomerate that are most common in the upper 400 feet $(120 \mathrm{~m})$. Their base is marked by a crossbedded sandstone that contains some pebbles derived from plutonic rocks and some large rounded limestone boulders. Their age is early Oxfordian, at least partly, as shown by the presence of Cardioceras (Scarburgiceras) martini Reeside about 400 feet $(120 \mathrm{~m})$ above their base (Imlay, 1964a, p. D6, D15, D16).

\section{NORTHERN WASHINGTON}

In the Cascade Mountains of northwestern Washington, the Upper Jurassic is represented in the lower part of the Nooksack Formation by Buchia piochii (Gabb) (USGS Mesozoic locs. 26253, 26267), by $B$. rugosa (Fischer) associated with $B$. mosquensis (von Buch) (USGS Mesozoic locs. 26249, 26265) (Popenoe and others, 1960 , p. 1533), and by Buchia fischeriana (d'Orbigny) and B. cf. B. blanfordiana (Stoliczka) (Univ. California, Berkeley, Nos. 34709-11; Jeletzky, 1965, pl. 3 , figs. 2-4). In addition, B. concentrica (Sowerby) may be represented by specimens identified as Aucella erringtoni Gabb by T. W. Stanton (in Smith and Calkins, 1904 , p. 27). The presence of $B$. rugosa and B. mosguensis is significant because they are widely distributed from Washington northward to Alaska and the arctic region (Frebold and Tipper, 1970, p. 14-21; Frebold, 1964a, p. 4; Imlay and Detterman, 1973, p. 11, 13, 19, 26, 27). They are unknown, however, in the United States south of northern Washington, except for one occurrence of $B$. rugosa at the base of the Knoxville Formation near Paskenta, Calif.
Disconformably beneath the Nooksack Formation in the Mount Baker area of Washington, about 3,500 feet of volcanic beds and some interbedded marine slate and graywacke is exposed that Misch $(1966$, p. 103, 118) named the Wells Creek Volcanics. In the lower part of these volcanic rocks, a few fossils were obtained that were identified as Middle Jurassic or younger by J. A. Jeletzky (cited in Misch, 1966, p. 118). Lower Jurassic beds have not yet been identified faunally in northwestern Washington, but they may be represented near the Canadian border by nonvolcanic shaly to silty sandstone that Misch $(1966$, p. 103, 117) named the Bald Mountain Formation.

The Lower Jurassic is possibly represented in northcentral Washington by a fairly large ammonite that has evolute coiling and straight simple ribs, as does the Arietitidae of Sinemurian and Pliensbachian Age. This ammonite (USGS Mesozoic loc. 17460) was collected in the SE1/4NE1/4NE1/4 sec. 21, T. 35 N., R. 26 E., about 2 miles northwest of Riverside in Okanogan County. This locality is nearly due south of Amy Lake, a little above the 2,000-foot contour on a northward-draining slope. The specimen is preserved in a black, thin-bedded phyllitic noncalcareous rock that was obtained from a limestone unit 300 feet $(90 \mathrm{~m})$ thick. That unit underlies 200 feet $(60 \mathrm{~m})$ of gray limestone and dolomite and overlies the same thickness of amphibole-pyroxene.

The Jurassic is possibly represented about 30 miles $(48 \mathrm{~km})$ west-southwest of Riverside near Twist and Winthrop by the Twist Formation of Barksdale (1975, p. $22-24,65,66$, figs. $4,8,14,15$ ). That formation consists mostly of argillitic black shale that is interbedded with some dark volcanic siltstone and volcanic sandstone. It is at least 4,000 feet $(1,220 \mathrm{~m})$ thick, but its total thickness cannot be determined because of tight folding. It rests unconformably on gneiss, schist, and coarse-grained igneous rocks and is overlain unconformably by the Buck Mountain Formation of Early Cretaceous (Hauterivian to Barremian) age. Its exact age is uncertain because it has yielded only molds of belemnites and of fragments of cycads. Barksdale $(1975$, p. 22-24) suggested, however, that the Twist Formation is possibly of Early to Middle Jurassic age. Such an age is supported by the presence of an Early Jurassic ammonite in similar black rock near Riverside.

\section{BRITISH COLUMBIA TO SOUTHERN ALASKA}

Reasonably accurate interpretations of Jurassic history in California, Nevada, Washington, and Oregon require that the Jurassic sequences exposed there be compared and correlated with some of the best known sequences in westernmost Canada (Brown, 1968; Crickmay, 1930, 1962; Frebold, 1951a, b; 1964a, 1964d, 1966, 1967a, 1967b; Frebold and Tipper, 1967, 1970, 1973; Fre- 
bold, Tipper and Coates, 1969; Jeletzky, 1950, 1953, 1965; Jeletzky and Tipper, 1968; McLearn, 1929, 1932, 1949; Tipper and Richards, 1976) and southern Alaska (Berg, Jones, and Richter, 1972; Grantz, 1960, 1961; Imlay and Detterman, 1973, p. 10, 11; MacKevett, 1969, 1971; Richter and Jones, 1973). Such comparisons (fig. 24) aid greatly in determining the time, duration, and geographic extent of major events in the Pacific Coast region during Jurassic time.

These sequences show that the Jurassic beds of British Columbia resemble those of southern Alaska in many respects. First, they contain essentially the same succession of ammonites and buchias. Second, they contain enormous amounts of volcanic sedimentary rocks of Sinemurian to middle Callovian Age but generally only minor amounts of volcanic sedimentary rocks of older and younger Jurassic age. Third, they include unconformities of early Bajocian, late Bathonian, and late Callovian Age. Fourth, the early Bajocian unconformity coincides in time with igneous intrusions, as in parts of southern Alaska (Detterman and Hartsock, 1966, p. 63, 64, 69, 71; Grantz and others, 1963, p. B58). Fifth, an unconformity of possible late Oxfordian to latest Tithonian Age in British Columbia coincides partly in time with an unconformity at the top of the Jurassic in the Cook Inlet region in southern Alaska (Imlay and Detterman, 1973, p. 10, 11, $15,16)$. Sixth, granitic intrusions that cut lower Oxfordian rocks in the Harrison Lake area of British Columbia could be of the same age as a granodiorite intrusion in Alaska's Wrangell Mountains (Imlay and Detterman, 1973, p. 11).

The Jurassic sequences in British Columbia are likewise similar to those to the south in certain respects. Sequences in these two areas have the same general succession of ammonites and of species of Buchia, enormous amounts of volcanic material, granitic intrusions younger than early Oxfordian and possibly of Tithonian Age, and unconformities, or disconformities, of earliest Bajocian, Bathonian, late Callovian, and locally of late Kimmeridgian to Tithonian Age.

The Jurassic sequences in the westernmost conterminous United States differ from those in British Columbia in several respects. Faunally, they lack the pelecypod Buchia mosquensis (von Buch) except in northwestern Washington; lack ammonites of Bathonian Age except in eastern Oregon; lack the Callovian ammonite Cadoceras; contain the ammonites Macrocephalites and Peltoceras of earliest and latest Callovian Age, respectively; and contain ammonites of Tethyan affinities in beds younger than early Oxfordian. Lithologically, they contain much greater thicknesses of volcanic beds of Callovian Age and much more volcanic material in beds younger than Callovian. Orogenically, they include a widespread unconformity of early Pliensbachian Age that is not recognized in British Columbia except possibly in the western part of Vancouver Island (Jeletzky, 1970, p. 22, 23). The most striking difference is that Tithonian beds in California and Oregon occur only in the westernmost parts of those States and represent mainly the upper part of that stage.

In contrast, on the mainland of British Columbia, beds of Tithonian Age locally pass conformably downward into beds of Kimmeridgian and Oxfordian Age (Jeletzky and Tip, 1968) and occur at many places throughout the central and southern part of the province as far east as westernmost Alberta (Frebold and Tipper, 1970, p. 15). Evidently, in latest Jurassic time, marine waters spread much farther east in British Columbia and apparently also in Washington than in areas to the south. This eastward spread is related to the presence of certain major structural features (Jeletzky, 1970; Jeletzky and Tipper, 1968 , p. $3-5,71-83$, fig. 7 on p. 76 ). These features include several southeast trending sedimentary troughs separated by land areas (Tipper and Richards, 1976 , p. 8, 41). Presumably, the sea that occupied these troughs once extended eastward to the sea that occupied the western interior region from early Bajocian to late Oxfordian or early Kimmeridgian time.

\section{WESTERN INTERIOR REGION OF THE UNITED STATES}

\section{MONTANA AND NORTH DAKOTA}

Marine Jurassic beds in Montana and North Dakota (fig. 25) are of early or middle Bajocian to late Oxfordian Age (Reeside, 1919; Crickmay, 1936; Imlay, 1948, 1953a, 1954, 1962b, 1967b; J. A. Peterson, 1954a, 1954b; Swain and Peterson, 1951, 1952; Loeblich and Tappan, 1950a, 1950b; Carlson, 1968, p. 1973-1979; Schmitt, 1953). They rest unconformably on beds of Mississippian to Triassic age (Imlay, Gardner, and others, 1948; McKee and others, 1956; J. A. Peterson, 1972, p. 186); and are overlain gradationally by the continental Morrison Formation of Kimmeridgian to possible early Tithonian (Portlandian) Age (Yen, 1952; Peck, 1956; Mitchell, 1956). The Morrison Formation thins northward, disappears near the Canadian border, and is overlain unconformably by the Kootenai Formation of Aptian and possibly also Neocomian Age (Cobban and Reeside, 1952, p. 1016; McGookey and others, 1972, p. 192, 193, 195).

The Nesson Formation is the oldest known Jurassic formation in Montana and North Dakota. It occurs only in the subsurface of the Williston basin between central Montana and central North Dakota and consists of three lithologically distinct members (Nordquist, 1955, p. 104106; Rayl, 1956, p. 36-38). The oldest, the Poe Evaporite Member, averages about 120 feet $(36 \mathrm{~m})$ in thickness and consists of massive salt or gypsum overlain by interbedded gypsum, dark-red shale and some beds of 


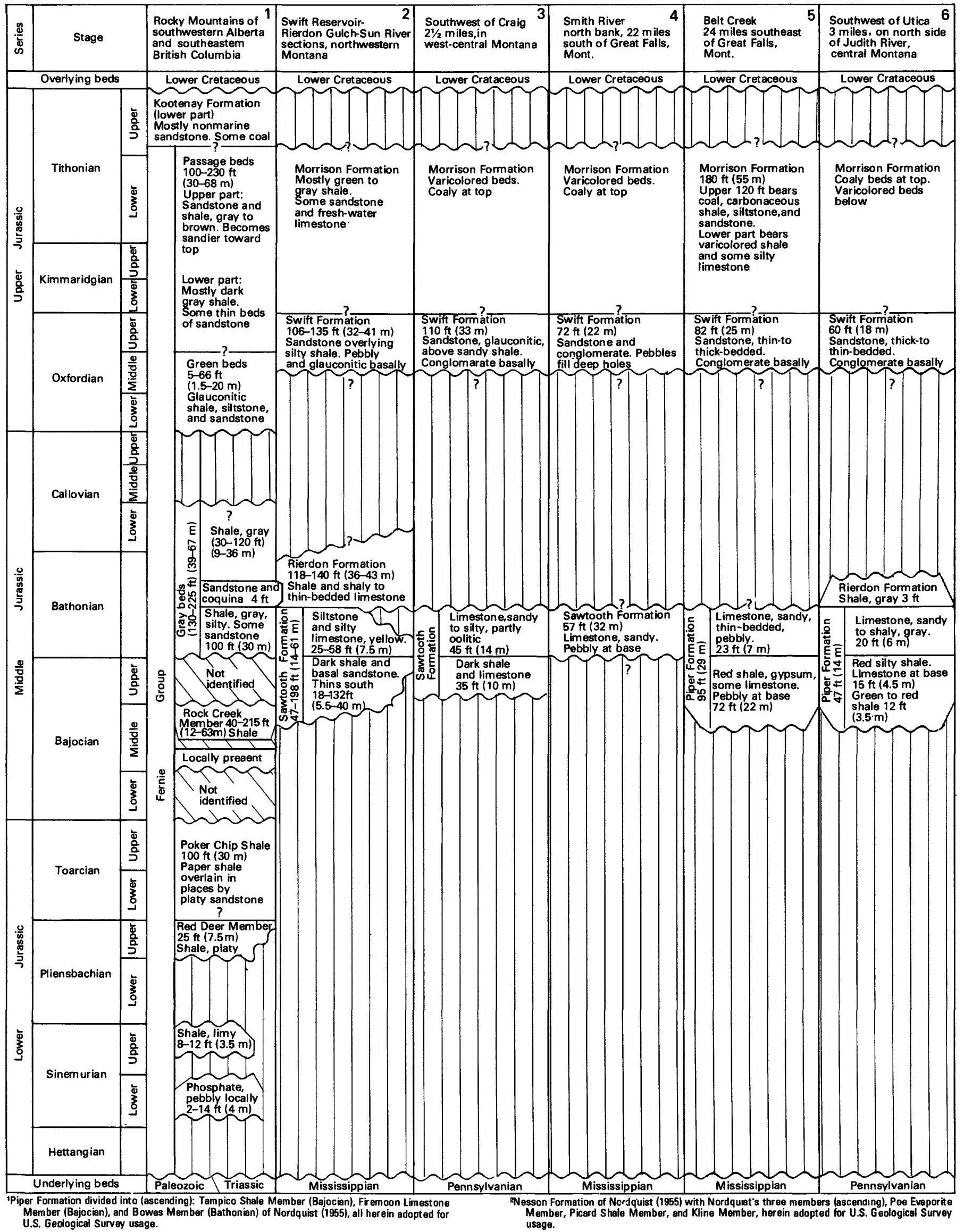

A. Southwestern Alberta to central Montana. 


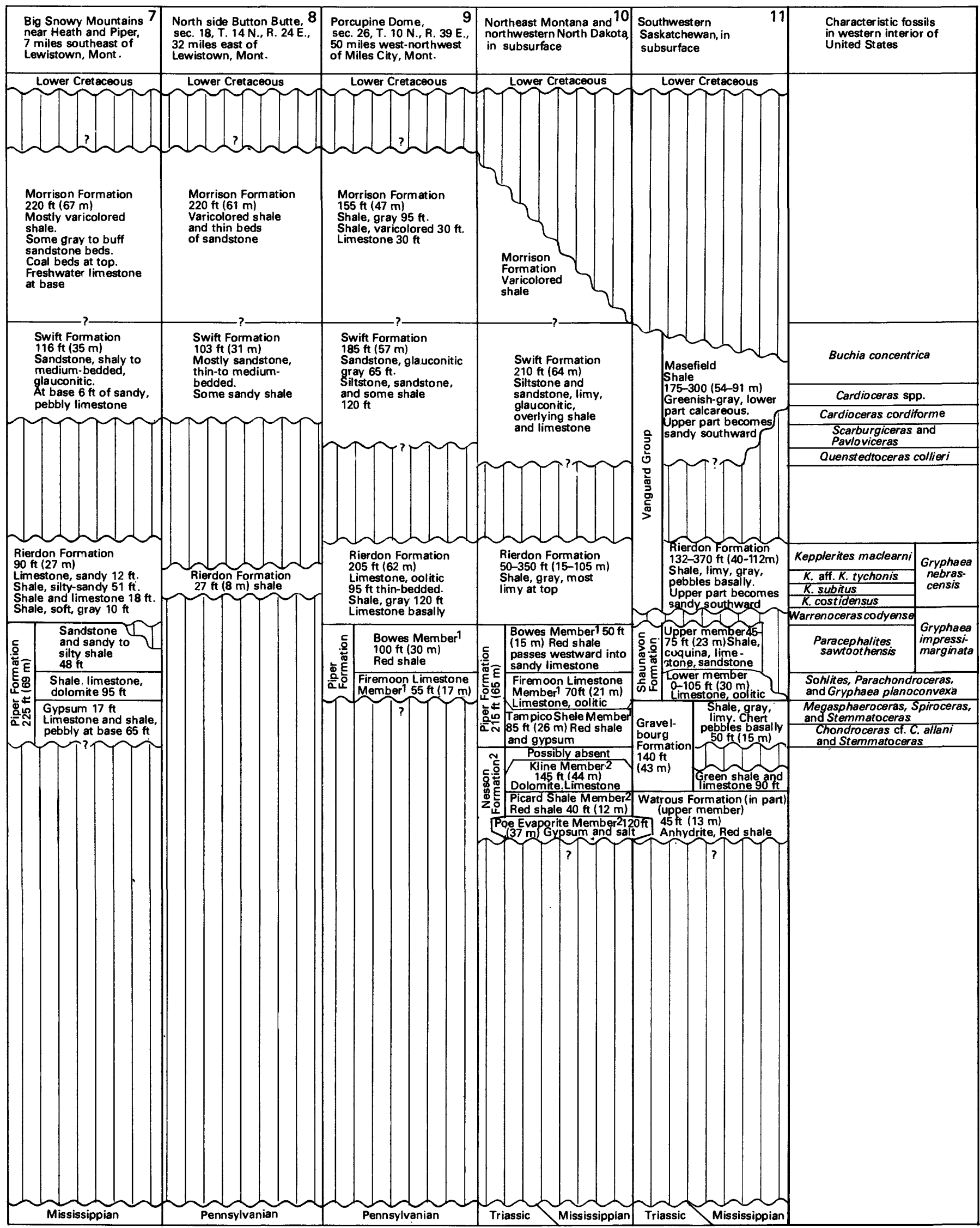

B. Central Montana to southern Saskatchewan.

FIGURE 25.-CORRELATIONS AND COMPARISONS OF JURASSIC ROCKS IN THE WESTERN INTERIOR REGION FROM SOUTHWESTERN ALBERTA THROUGH CENTRAL MONTANA TO SOUTHERN SASKATCHEWAN. Vertical lines indicate that strata are missing; diagonal lines indicate lack of fossil data; wavy lines indicate unconformity or disconformity. Column numbers refer to locations shown on figure 20. 


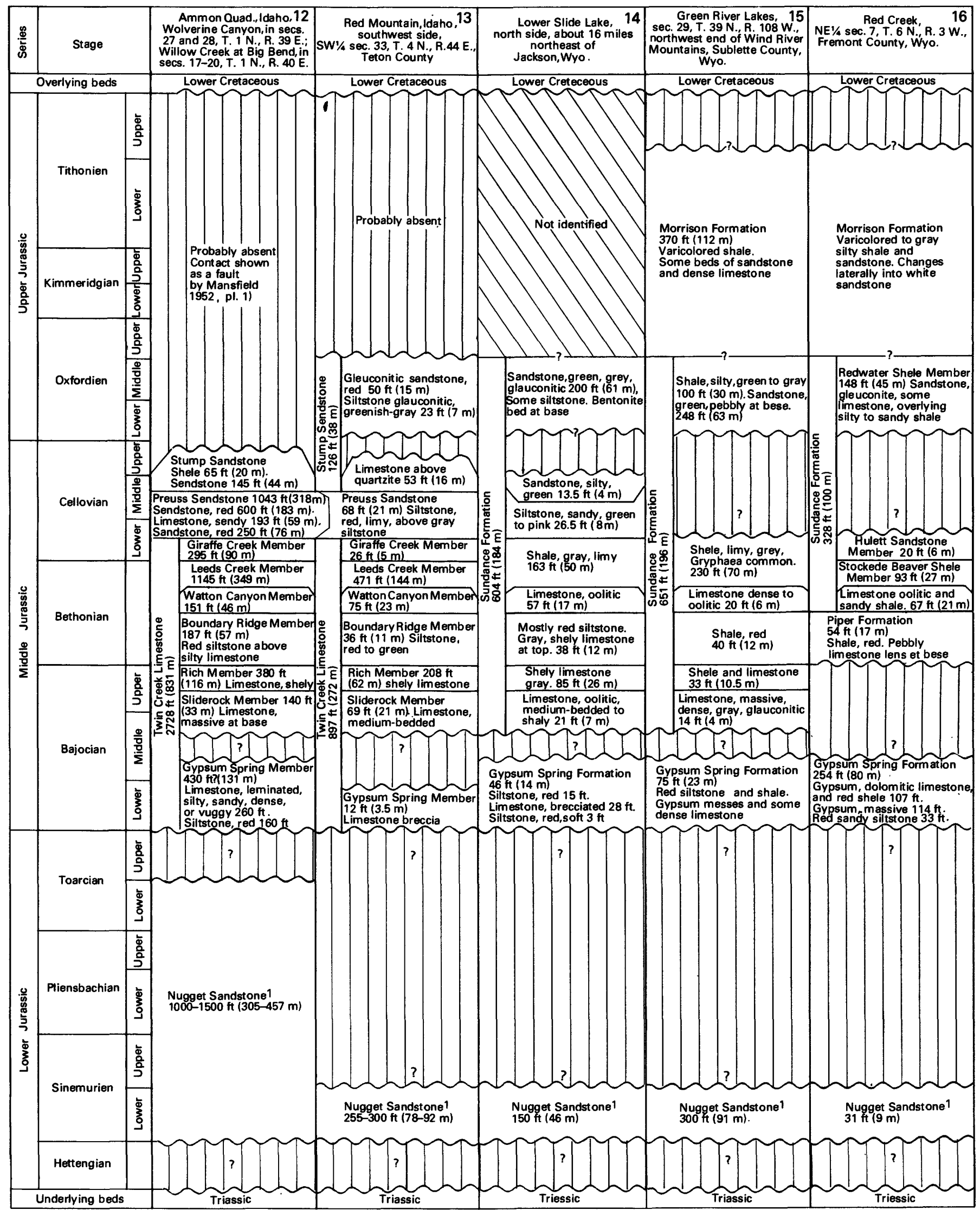




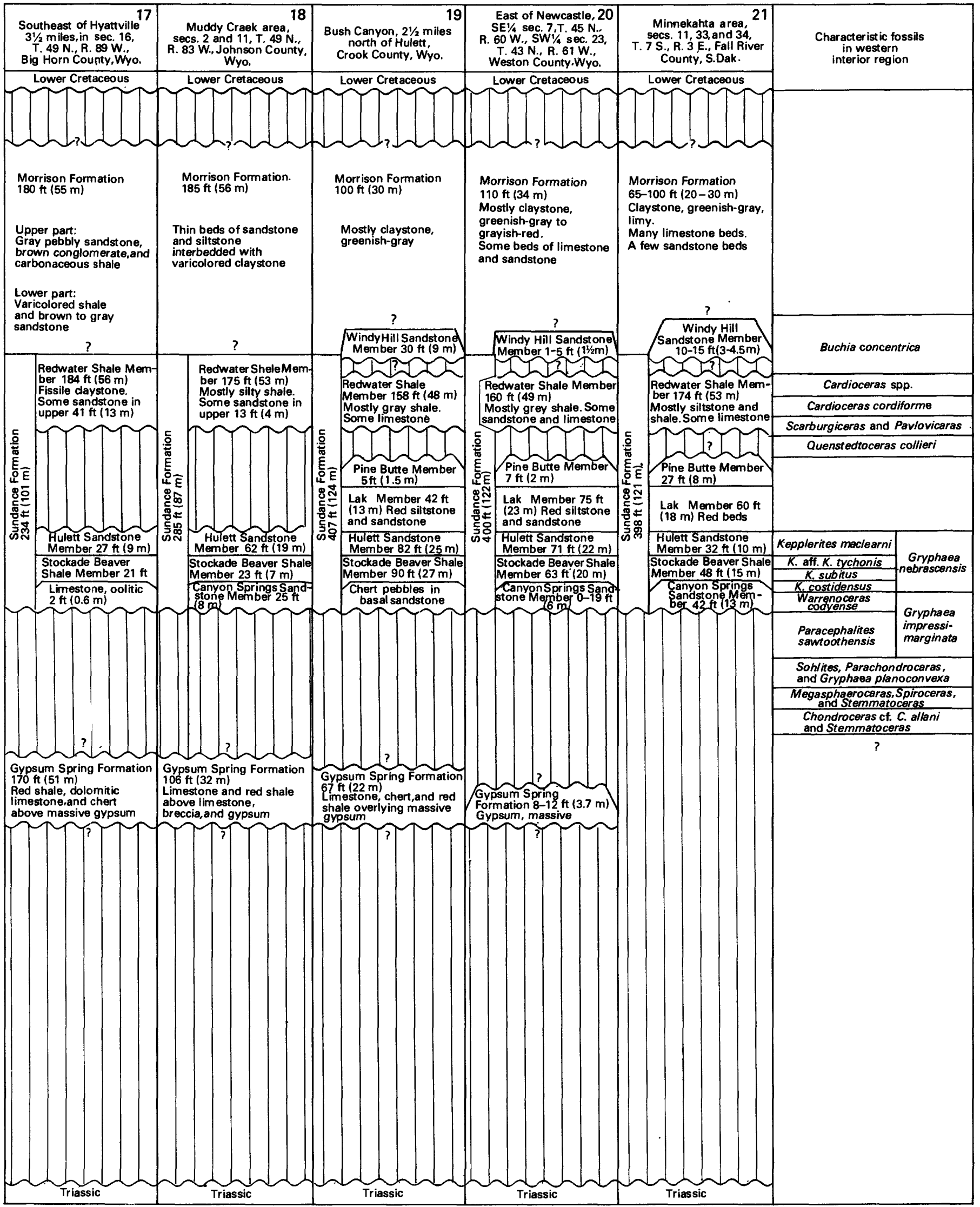

B. Hyattville area in north-central Wyoming to Minnekahta area, South Dakota.

FIGURE 26.-CORRELATIONS AND COMPARISONS OF JURASSIC ROCKS IN THE WESTERN INTERIOR REGION FROM SOUTHEASTERN IDAHO TO SOUTHWESTERN SOUTH DAKOTA. Vertical lines indicate that strata are missing; diagonal lines indicate lack of fossil data; wavy lines indicate unconformity or disconformity. Column numbers refer to locations shown on figure 20. 


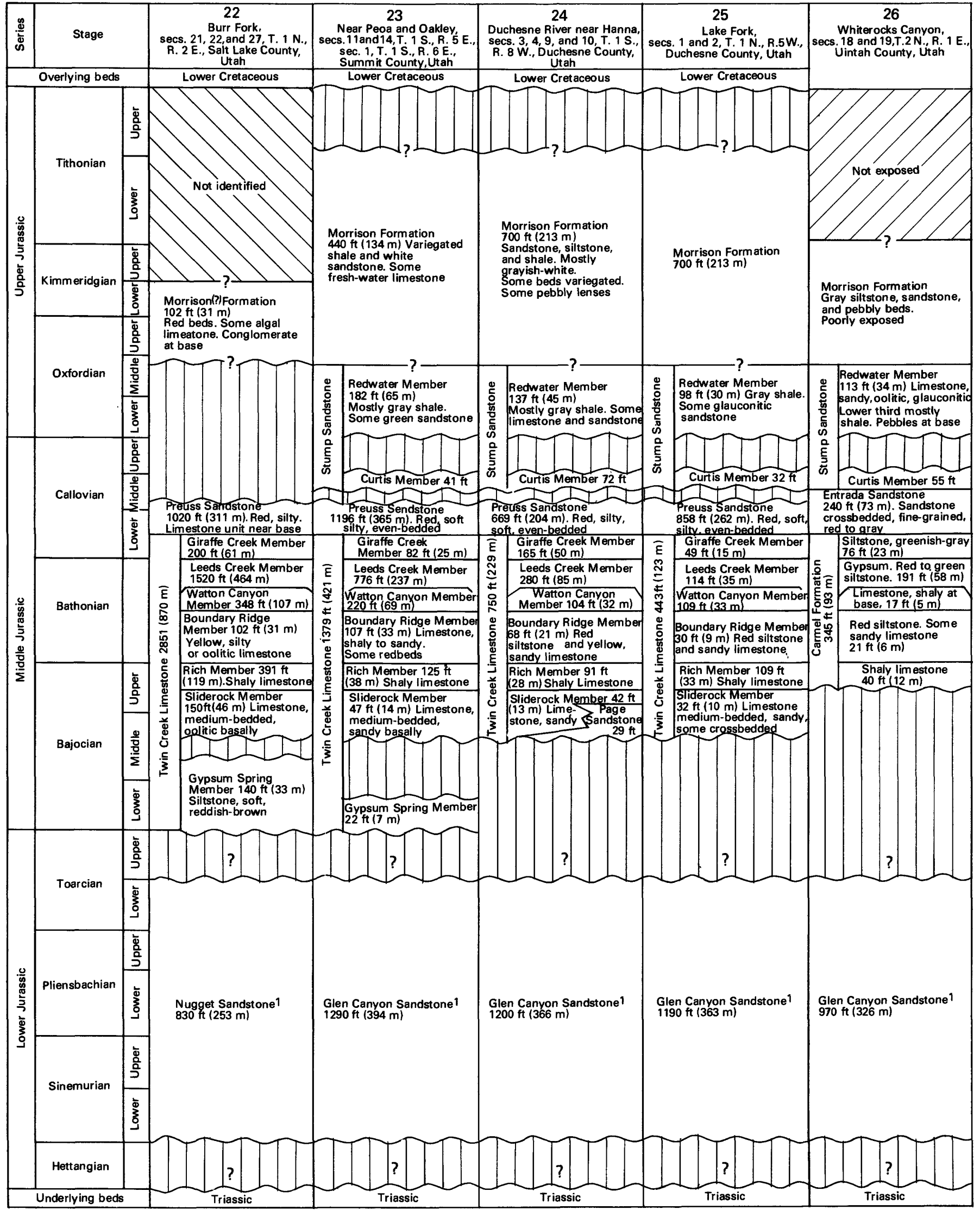

IIn this author's opinion.

A. Burr Fork to Whiterocks Canyon, Utah. 


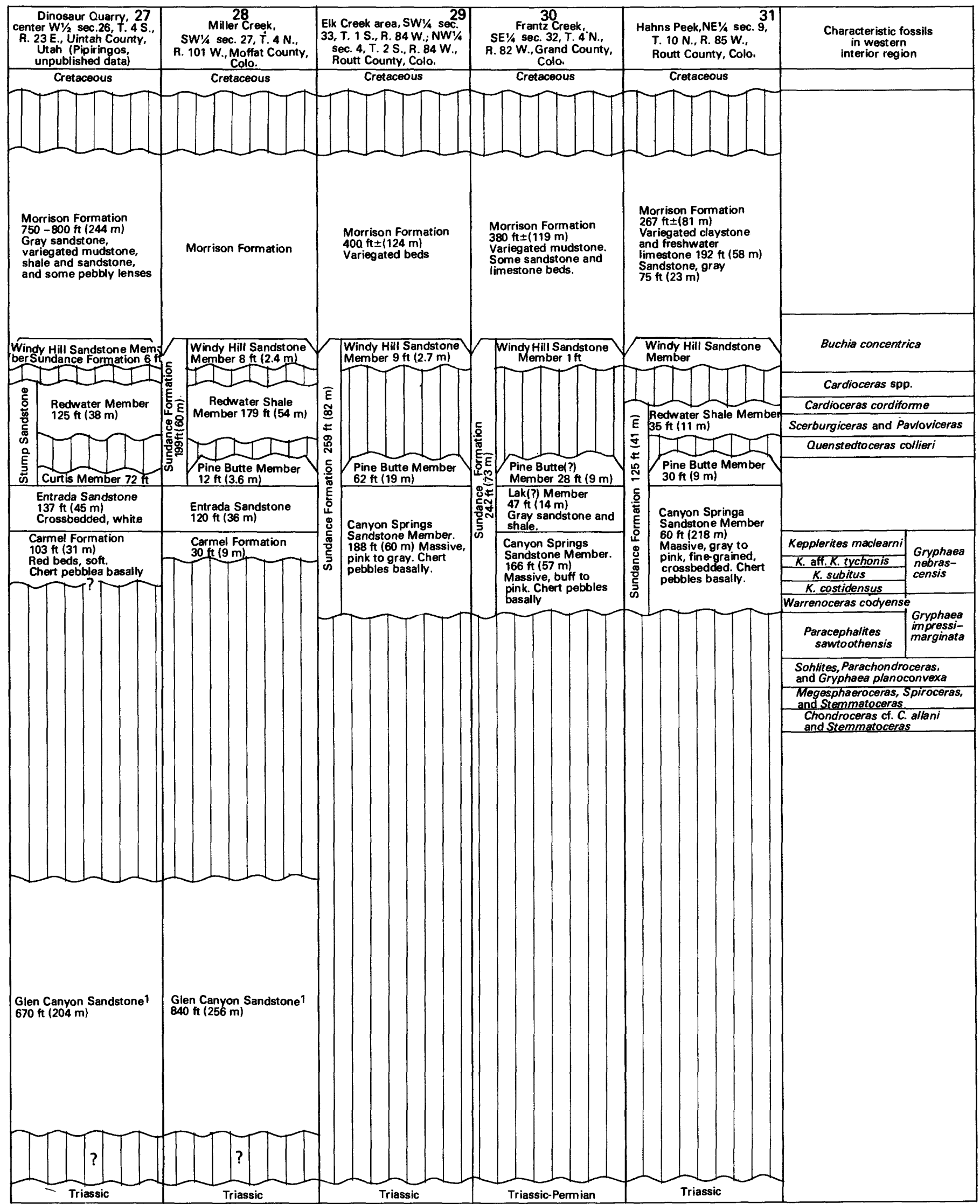

B. Dinosaur Quarry, Utah, to Hahns Peak, Colo.

FIGURE 27.-CORRELATIONS AND COMPARISONS OF JURASSIC ROCKS IN THE WESTERN INTERIOR REGION FROM NORTH-CENTRAL UTAH TO NORTH-CENTRAL COLORADO. Vertical lines indicate that strata are missing; right-diagonal lines indicate strata not exposed; left-diagonal lines indicate lack of fossil data; wavy lines indicate unconformity or disconformity. Column numbers refer to locations shown on figure 20 . 


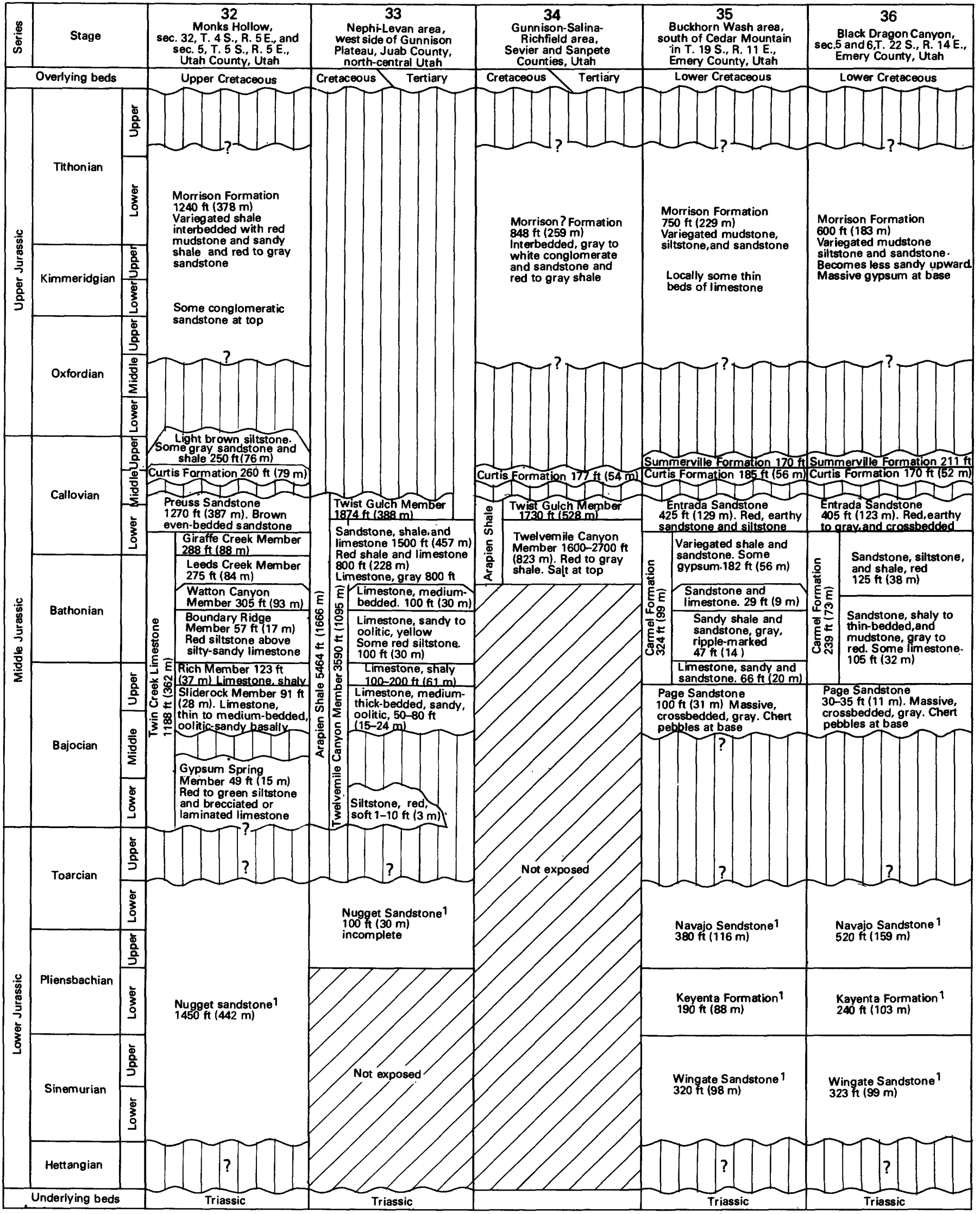

IIn this author's opinion.

A. Monks Hollow to Black Dragon Canyon, Utah. 


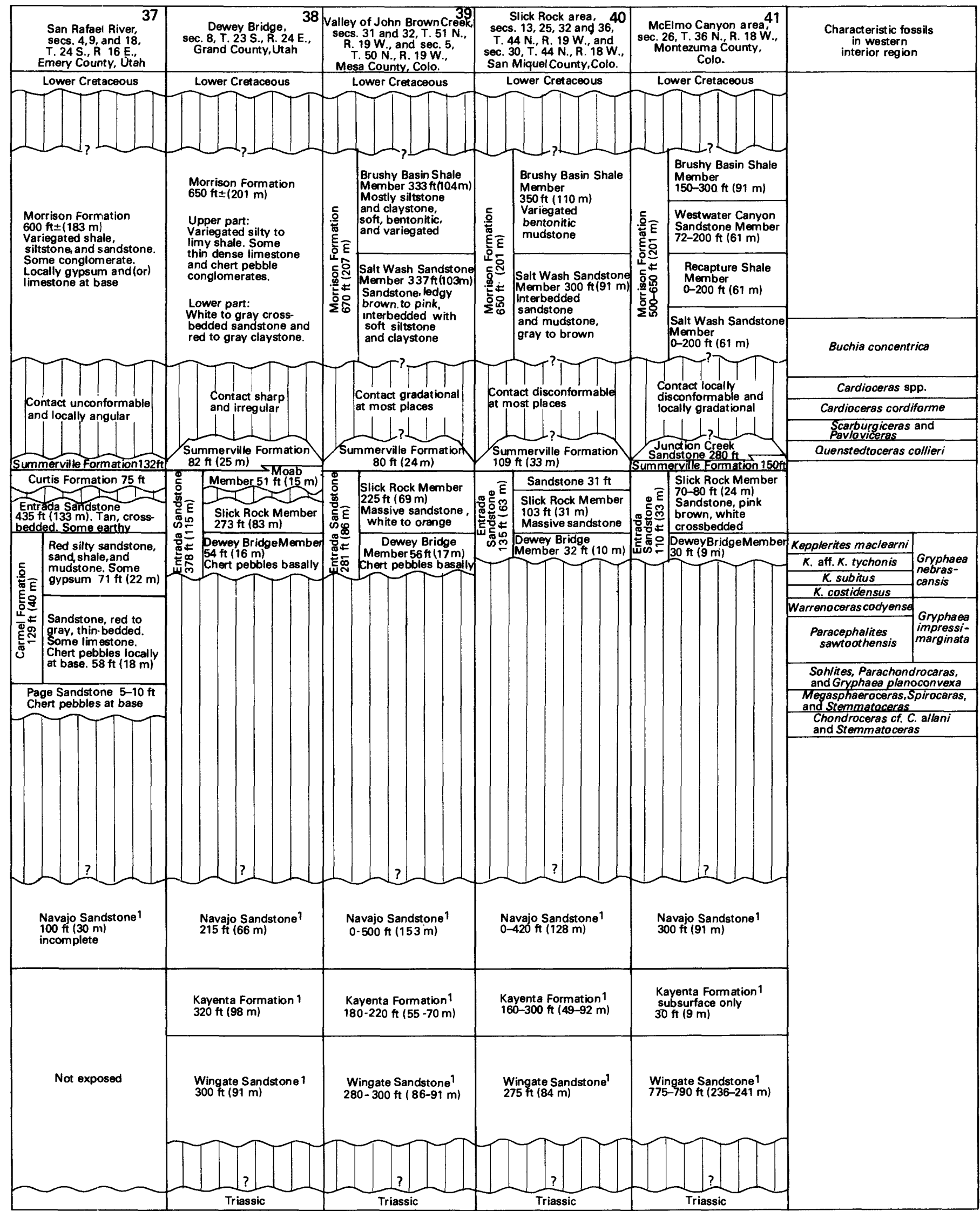

$B$. San Rafael River, Utah, to McElmo Canyon, Colo.

FIGURE 28.-CORRELATIONS AND COMPARISONS OF JURASSIC ROCKS IN THE WESTERN INTERIOR REGION FROM NORTH-CENTRAL UTAH TO SOUTHWESTERN COLORADO. Vertical lines indicate that strata are missing; right-diagonal lines indicate strata not exposed; left-diagonal lines indicate lack of fossil data; wavy lines indicate unconformity or disconformity. Column numbers refer to locations shown on figure 20 . 


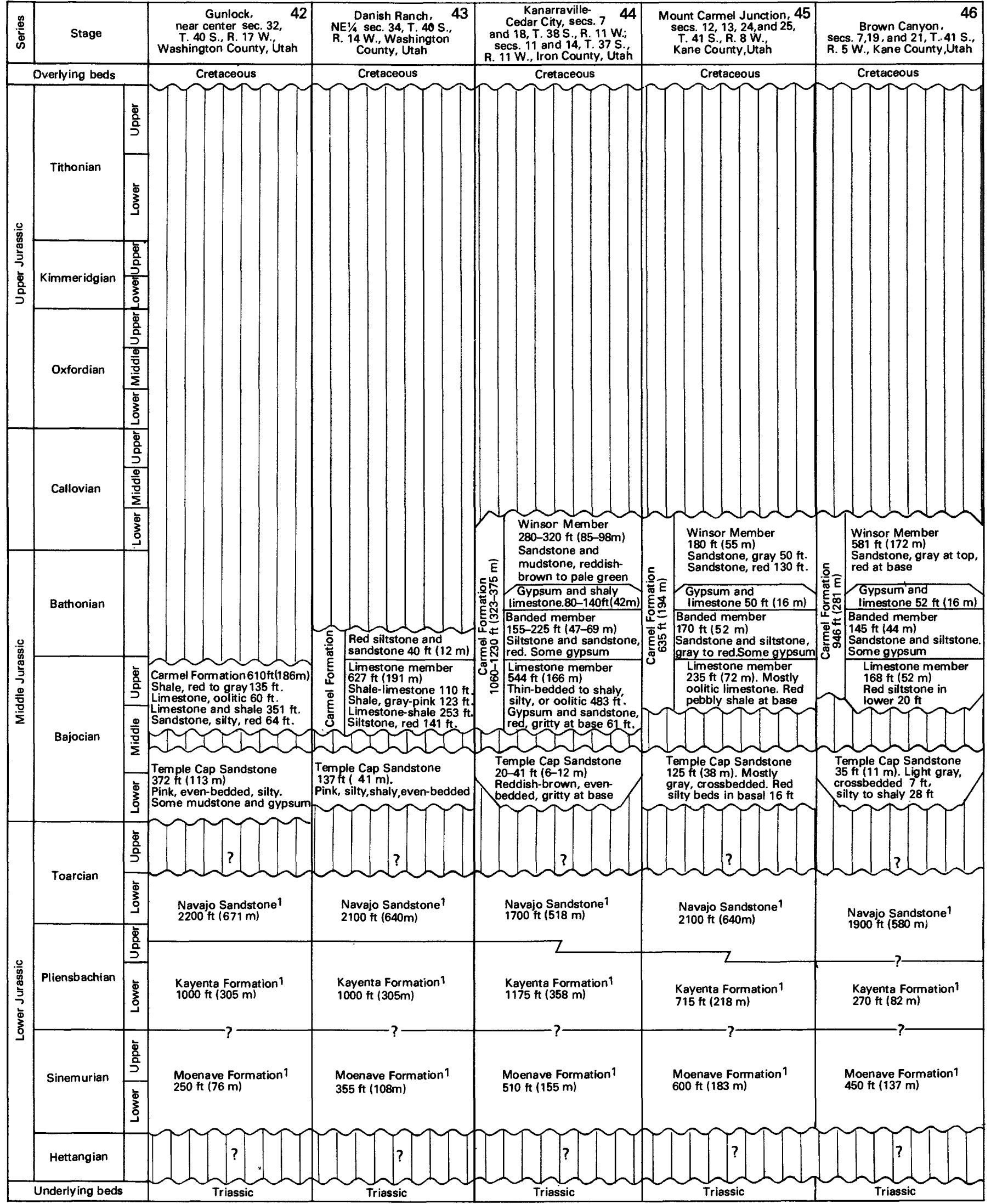

1/n this author's opinion.

A. Gunlock to Brown Canyon, Utah. 


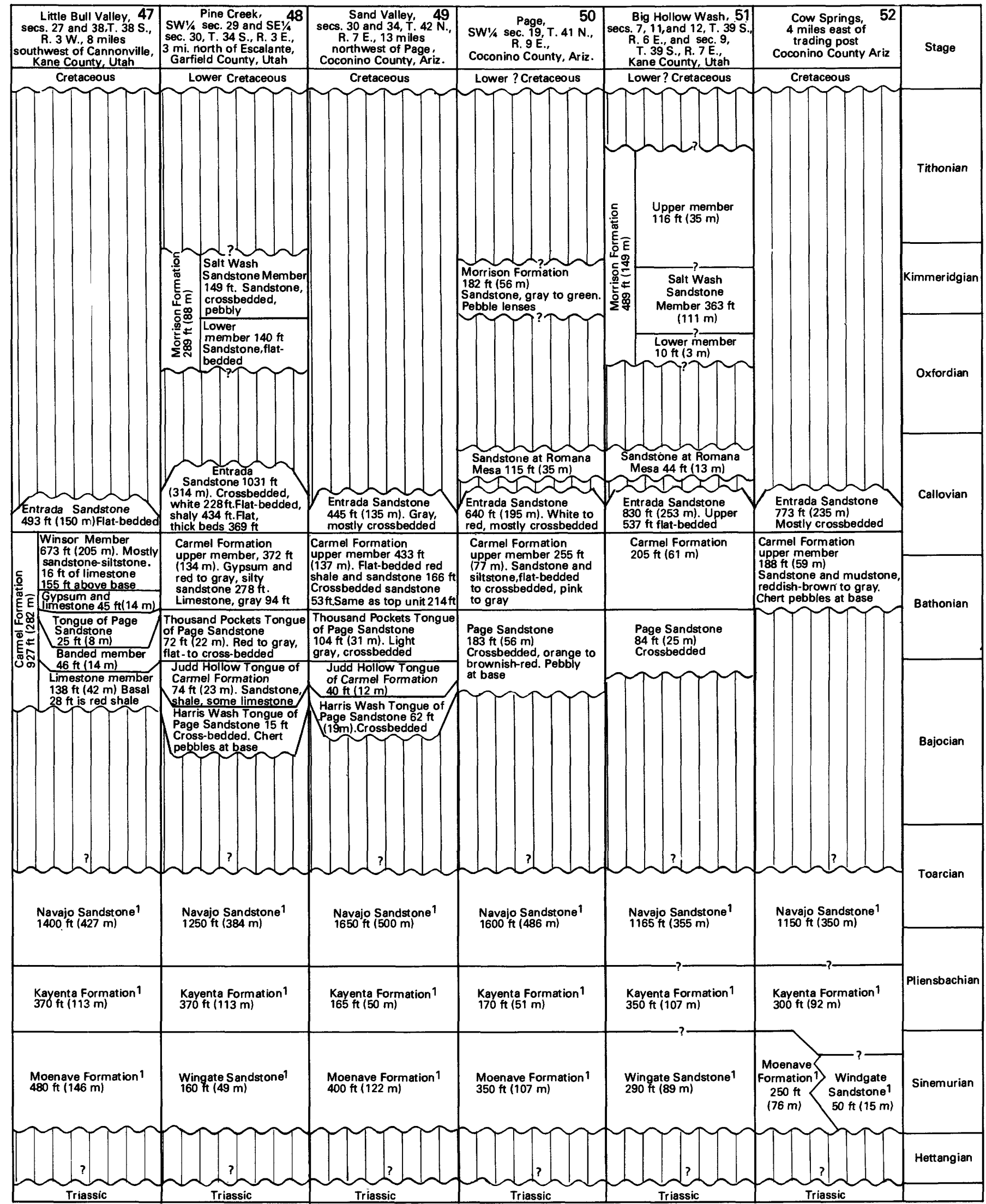

B. Little Bull Valley, Utah, to Cow Springs, Ariz.

FIGURE 29.-CORRELATIONS AND COMPARISONS OF JURASSIC ROCKS IN THE WESTERN INTERIOR REGION FROM SOUTHWESTERN UTAH TO NORTHEASTERN ARIZONA. Vertical lines indicate that strata are missing; wavy lines indicate unconformity or disconformity; jagged lines indicate gradational or indefinite contact. Column numbers refer to locations shown on figure 20. 
dense dolomite. It is overlain gradationally by the Picard Shale Member, which is about 40 feet $(12 \mathrm{~m})$ thick and consists mostly of dark-red shale but contains some gypsum at its base. The Picard is overlain rather sharply by the Kline Member, which ranges from 80 to 190 feet (24 to $58 \mathrm{~m}$ ) in thickness, consists generally of an upper dense dolomitic unit and a thicker lower limestone unit that locally is oolitic, and also contains some beds of finegrained sandstone and green to purple shale. The upper contact of the Kline with the Piper Formation is sharp but concordant. The possibility of a disconformity at the top of Kline Member is suggested by the presence of chert pebbles at the top of the equivalent lower member of the Gravelbourg Formation in Saskatchewan (Milner and Blakslee, 1958, p. 71; Springer and others, 1966, p. 144; Milner and Thomas, 1954, p. 257).

The exact age of the Nesson Formation is not known. An early Bajocian or older age was suggested by Nordquist (1955, p. 105) on the basis of stratigraphic position. An Early Jurassic age was suggested by Pocock (1970, p. 15) on the basis of pollen studies of the partially equivalent lower member of the Gravelbourg Formation in southern Saskatchewan. For the same lower member, an early to middle Bajocian Age was suggested by Brooke and Braun (1972, p. 4). Apparently no evaluation has been made of the many fossils reported from the Kline Member by Nordquist (1955, p. 105). The possibility exists that the subsurface Kline Member of the Nesson Formation and the overlying Firemoon Limestone and Tampico Shale Members of the Piper Formation are the expanded basinward subsurface equivalents of the outcropping middle member of Piper Formation in the Big Snowy Mountains, as proposed by J. A. Peterson (1957, p. 435). It is more probable, however, that the Nesson Formation is the time equivalent of the Gypsum Spring Formation of northern Wyoming (fig. 26), as originally defined by Love (1939, p. 42, 45; Love and others, 1945) and as proposed by Francis (1956, p. 22-26, 46, fig. 4).

Correlation of the subsurface Nesson Formation with the Gypsum Spring Formation rather than with parts of the surface Piper Formation is favored by the greater stratigraphic and lithologic resemblances of members of the Nesson to the successive units of the Gypsum Spring Formation and by the fact that the upper limestone member of the Nesson Formation is more dolomitic and much less fossiliferous than the middle limestone member of the Piper Formation. Also, the Gypsum Spring Formation extends northward into Montana unconformably beneath the Piper Formation along the flanks and northern ends of the Pryor and Bighorn Mountains.

Recognition of the presence of the Gypsum Spring Formation beneath the Piper Formation was made possible by joint field studies in 1964 and 1971 by G. N. Pipiringos and the writer, who traced typical exposures of the Gypsum Spring Formation northward from the Wind River Basin. These studies showed that the limy units in the Gypsum Spring Formation are commonly dolomitic, dense, white to light gray, are locally pinkish or greenish, are nonoolitic, poorly fossiliferous, and contain blocky or banded chert in some beds. By contrast, the limy units in the Piper Formation are shaly to thin-bedded, commonly oolitic, highly fossiliferous, do not contain chert, and are not dolomitic. Also, the base of the Piper Formation at some localities contains small chert pebbles that are lithologically identical with the bedded chert in the Gypsum Spring Formation. Such pebbles were noted along the Pryor Mountains at the head of Gypsum Creek, at Red Dome, and at Grapevine Creek. Their stratigraphic occurrence should not be confused with that of much larger pebbles consisting of both chert and quartzite near the top of the limestone member of the Piper Formation in the Pryor Mountains (Imlay, 1956a, p. 572574).

On the basis of the criteria cited, the thicknesses of the Piper and the underlying Gypsum Spring Formation have been determined for the area of the Pryor and Bighorn Mountains (table 1). Evidently, the Gypsum Spring is thinnest along the west side of the Pryor Mountains and thickens eastward from 17 feet $(5 \mathrm{~m})$ at Red Dome to about 150 feet $(46 \mathrm{~m})$ at the Montana-Wyoming State line on both sides of the Bighorn Mountains. Also, the Piper Formation is thickest on the west side of the Pryor Mountains and thins eastward from 163 feet $(50 \mathrm{~m})$ at Red Dome to about 55 feet $(17 \mathrm{~m})$ at the State line north of Cowley, Wyo., and to about 40 feet $(12 \mathrm{~m})$ at Lodge Grass Creek, near the State line on the east side of the Bighorn Mountains.

Lithologically, the thickest sequences of the Gypsum Spring Formation in the Pryor Mountains greatly resemble sequences typical of that formation in the Wind River Basin. At the base is a unit of massive gypsum and some red siltstone, or a unit of red siltstone that contains brecciated beds. Above this unit is one of soft red claystone. At the top is a unit consisting of interbedded gray limestone, white to light-gray dolomitic limestone, and some varicolored claystone. As the formation thins toward the west in the Pryor Mountains, the upper units disappear from the top downwards so that only the basal gypsiferous unit is present along the west side of the mountains. Evidently, the Gypsum Spring Formation was truncated by erosion before the Piper Formation was deposited.

Similarly, the thickest sequences of the Piper Formation in the Pryor Mountains contain all the units typical of the Piper elsewhere in Montana. For example, at Red Dome in Carbon County, Mont., the formation consists of a basal red claystone about 24 feet $(7 \mathrm{~m})$ thick, overlain by interbedded, fossiliferous gray shale and limestone about 60 feet $(18 \mathrm{~m})$ thick, which is overlain by 
TABLE 1.-Thickness of the Piper and underlying Gypsum Spring Formations in parts of north-central Wyoming and south-central Montana

[B, indicates the presence of breccia instead of massive gypsum]

\begin{tabular}{|c|c|c|}
\hline \multirow[t]{3}{*}{ Location } & $\begin{array}{c}\text { Piper } \\
\text { Formation }\end{array}$ & $\begin{array}{c}\text { Gypsum } \\
\text { Spring Formation }\end{array}$ \\
\hline & Thickness & Thickness \\
\hline & Meters & Meters \\
\hline
\end{tabular}

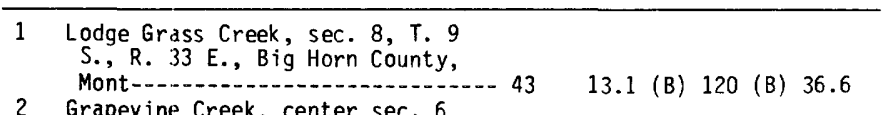

Mont-....................................

Grapevine Creek, center sec. 6

T. 6 S., R. 31 E., Big Horn

3 County, Mont-- Shively 20

al part

Sec. 23, T. 5 S., R. 27 E., Big

Horn County, Mont-...-....- 66

4 Fivemile Creek, sec. 36 T. 5

S., R. 24 E., Carbon County,

Mont-_........ 90

Dome, west flank, sec. 19

T. 7 S., R. 24 E., Carbon

County, Mont-...

6 South of Bowler 1-1/2 mi,

Sec. 1, T. 8 S., R. 24 E.,

Carbon County, Mont -...... 95

7 South side of Pryor Mountains,

S-1/2 sec. 14, T. 9 S., R. 26

E., Carbon County, Mont-..

8 East side of Gypsum Creek,

SE-1/4 sec. 33, T. 9 S., R. 27

E., Carbon County, Mont-_..... 64

9 East side of Red Gulch, sec.

22, T. 58 N., R. 89 W., Sheridan

County, Wyo-............ Sheridan 46

Wolf Creek, NW-1/4 sec. 9, T.

55 N., R. 86 W., Sheridan

County, Wyo--., Sheridan 5

11 Big Goose Creek, NE-1/4 sec. 2,

T. 54 N., R. 86 W., Sheridan

County, Wyo-

Little Goose Creek, N-1/2
36, T. 54 N., R. 85 W.,

Sheridan County, Wyo-..

13 North side of Sykes Mtn.,

NE-1/4 sec. 12, T. 57 N., R.

95 W., Big Horn County, Wyo

14 Northwest end of Little Sheep

Mtn. NW-1/4 sec. 28, T. 56 N.

R. 95 W., Big Horn County, Wyo--- 44

\begin{tabular}{|c|c|c|}
\hline 6.1 & 130 & 39.6 \\
\hline 20.1 (B) & $53(B)$ & 16.2 \\
\hline $27.4(B)$ & $46(B)$ & 14.0 \\
\hline 49.7 & 17 & 5.2 \\
\hline
\end{tabular}

TABLE 1.-Thickness of the Piper and underlying Gypsum Spring Formations in parts of north-central Wyoming and south-central Montana-Continued

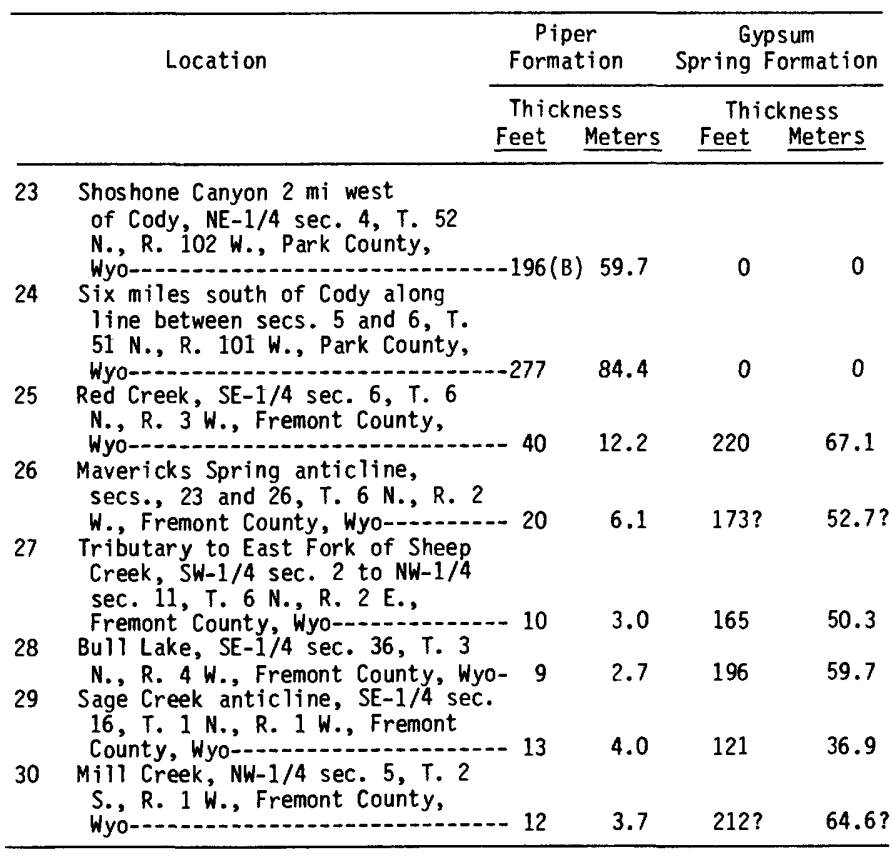

orthwest end of Spence Dome,

north-central part sec. $6, T$.

54 N., R. 94 W., Big Horn

County, Wyo-.., Big Horn

Southeast end of Sheep Mtn.,

east-central part sec. 16, T.

53 N., R. 93 W., Big Horn

Count y, Wyo-...........

17 About $7 \mathrm{mi}$ north-northwest

of Shell, south-central sec.

21 and north-central sec. 28 ,

T. 54 N., R. 91 W., Big Horn

County, Wyo-

east-central part sec. 3, T. 51

N., R. 91 W., Big Horn County,

Wyo-. 22

About 9 mi north-northwest

of Hyattville, SW-1/4 sec. 21,

T. 51 N., R. 90 W., Big Horn

County, Wyo-_a 30

2 mi northeast of

Hyattville, central sec. 29, T.

50 N., R. 89 W., Big Horn

1 mi north of mouth of

Clarks Fork Canyon, sec. 5,

56 N., R. 103 W., Park County,

Wyo-_._._.

Trail Creek, about $8 \mathrm{mi}$

northwest of Cody, center sec.

12, T. 53 N., R. 103 W., Park

County, Wyo-:-206
$14.0 \quad 150(B) 45.7$

1.5 (B) 143 (B) 43.6

1.5 (B) 142 (B) 43.3

18.0 (B) 146 (B) 44.5

$26.2 \quad 164 \quad 50.0$

$13.4 \quad 152 \quad 46.3$

29.0 (B) 64 (B) 19.5

$27.7 \quad 43 \quad 13.1$

$19.5 \quad 107 \quad 32.6$

40.

$11.0 \quad 210 \quad 64.0$

$13.4 \quad 110 \quad 33.5$

$\begin{array}{lll}10.4 & 162 & 49.4\end{array}$

$\begin{array}{lll}6.7 & 216 & 65.8\end{array}$

$9.1 \quad 192 \quad 58.5$

$3.4 \quad 174 \quad 53.0$

$68.0 \quad D \quad 0$

. 80
77 feet $(23 \mathrm{~m})$ of brownish-red claystone and siltstone that contains some thin layers of gypsum. As the formation thins toward the east, the units disappear from the base upwards, and at the State line east of the Bighorn Mountains, only the highest redbed unit is present. Thus, the Piper Formation overlaps eastward and southeastward over the Gypsum Spring Formation.

The Piper Formation consists of three members, is more widely distributed in the subsurface than is the Nesson Formation, and crops out at many places in north-central, central, and southern Montana. The oldest, or Tampico Shale Member (Nordquist, 1955, p. 101), is about 85 feet $(26 \mathrm{~m})$ thick in the subsurface and as much as 100 feet $(30.5 \mathrm{~m})$ thick on the surface. It consists mostly of red shale but includes some green to gray shale and siltstone, some thin beds of red to white sandstone, and some gray to brown dolomite and dolomitic limestone, and in places its lower part bears thick masses of gypsum (Imlay, Gardner, and others, 1948).

It is overlain by the middle, or Firemoon Limestone Member (Nordquist, 1955, p. 101), whose thickness averages about 75 feet $(23 \mathrm{~m})$ in the subsurface and ranges from 15 to more than 100 feet $(4.5$ to $30.5 \mathrm{~m})$ on the surface. It consists mostly of gray shale and limestone, which may be shaly, oolitic, dense, or dolomitic. Its boundaries with adjoining members are transitional within narrow intervals (Imlay, Gardner, and others, 1948b; Sandberg, 1959). 
The youngest, or Bowes Member, of the Piper Formation (Nordquist, 1955, p. 102) averages about 50 feet $(15 \mathrm{~m})$ in thickness in the Williston basin and from 20 to 130 feet (6 to $40 \mathrm{~m}$ ) in thickness in outcrops. It consists mostly of red to varicolored shale and siltstone in the subsurface east of the Big Snowy and Bearpaw Mountains, as well as on the surface in southern Montana as far west as the Gallatin Range north of Yellowstone National Park. It passes westward and northward in Montana into yellowish silty to sandy limestone and calcareous sandstone that characterize the upper member of the Sawtooth Formation in western and north-central Montana.

Northward from the Williston basin, the Piper Formation continues into southern Saskatchewan, where its Tampico Shale Member passes into gray calcareous shale at the top of the Gravelbourg Formation, its Firemoon Limestone Member passes into the nearly identical lower member of the Shaunavon Formation, and its Bowes Member passes into shale, limestone, and sandstone in the upper member of the Shaunavon Formation (Christopher, 1964, p. 16; Brooke and Braun, 1972, p. 4; Milner and Thomas, 1954, p. 258-262).

The middle limestone member of the Piper Formation is dated as late Bajocian because in both the surface and subsurface in Montana it contains certain mollusks (Hearn and others, 1964, p. B8; Imlay, 1967b, p. 33-35) that also characterize the upper Bajocian Rich Member of the Twin Creek Limestone (Imlay, 1967b, p. 31, 32). These include particularly the ammonites Sohlites and Parachondroceras and the pelecypods Gryphaea planoconvexa Whitfield and Gervillia? montanaensis Meek. Dating the Rich Member as latest Bajocian is based on its gradational relationship with the underlying Sliderock Member, whose upper half contains the ammonites Megasphaeroceras, Spiroceras, Stemmatoceras, Stephanoceras, and questionable Normannites. These in association can only be of early late Bajocian Age (Imlay, $1967 b$, p. 26,$27 ; 1973$, p. 29, 34).

Elsewhere, the mollusks that characterize the middle limestone member of the Piper Formation are widely distributed. They occur in the middle of the Sawtooth Formation south of Belt Island in Gallatin and Madison Counties, southwestern Montana (Imlay, 1967b, p. 33, $34,65)$. They occur throughout 27 feet $(8 \mathrm{~m})$ of black limestone and shale in the middle of the Sawtooth Formation exposed on East Butte in the Sweet Grass Hills, Liberty County, Mont. They occur in the lower member of the Shaunavon Formation in southern Saskatchewan (Paterson, 1968, p. 15, 16) along with the coral Actinastrea cf. A. hyatti (Wells) (Wells, 1942, p. 2, pl. 2, figs. 1a-c, $2 \mathrm{a}, \mathrm{b}$ ). That coral is widespread in the middle limestone member of the Piper Formation in southern Montana, in the middle limestone member of the Saw- toath Formation in southwestern Montana, in the middle limestone member of the Sawtooth Formation in the Bearpaw Mountains, and in equivalent limestone beds in the northern part of the Bighorn Basin (Imlay, 1956a, p. $567,568,577)$.

Dating the middle limestone member of the Piper Formation as latest Bajocian means that the upper member must be of Bathonian Age and that the lower member must be at least in part of early late Bajocian Age, equivalent to the ammonite-bearing upper part of the Sliderock Member of the Twin Creek Limestone. This dating for these three members holds also for the three members of the Sawtooth Formation in southwestern Montana. However, the basal part of the lower member of the Piper Formation may be as old as the late middle Bajocian (Stephanoceras humphriesianum zone) because ammonites of that age occur near the base of the Sawtooth Formation (Imlay, 1967b, p. 50, 91-94) in northwestern Montana, because the lower part of the Sliderock Member could be of that age, and because marine invasion from the west probably took place at about the same time in eastern Idaho as in western Montana. Nonetheless, it is doubtful whether marine waters older than latest Bajocian ever crossed the Sweetgrass arch or Belt Island, because the members of the Sawtooth Formation thin considerably where they cross the arch (Cobban, 1945, p. 1271; Weir, 1949, p. 551, 552) and because the middle member of the Sawtooth Formation on East Butte in the Sweet Grass Hills correlates faunally with the upper Bajocian Rich Member of the Twin Creek Limestone (Imlay, 1967b, p. 35).

The Sawtooth Formation, in western and north-central Montana, is 230 feet $(70 \mathrm{~m}$ ) or less in thickness, consists of normal marine shale, sandstone, and limestone, and passes eastward gradually into the Piper Formation. Most of the gradation is near a line drawn northward from the northwest corner of Yellowstone National Park, although in north-central Montana the upper member of the Sawtooth Formation is represented by sandstone and silty limestone as far east as the Bearpaw Mountains in south-central Blaine County.

In northwestern Montana, north of Belt Island, the westernmost exposures of the Sawtooth Formation consist typically of a thin lower sandstone member, a middle shale member, and an upper calcareous siltstone-sandstone member. The lower sandstone member ranges from 8 to 30 feet $(2.4$ to $9 \mathrm{~m}$ ) in thickness, is ripple marked, and locally bears a basal conglomerate. The middle shale member thickens northward from about 18 feet $(5 \mathrm{~m})$ at the Sun River to about 170 feet $(52 \mathrm{~m})$ near Glacier National Park and consists mostly of poorly fossiliferous gray to black shale that contains lenses and nodules of phosphate throughout and some glauconitic sandstone at its base. The upper member thickens north- 
ward from 25 to 65 feet ( 7.6 to $20 \mathrm{~m}$ ) and consists of gray to yellowish-gray siltstone, sandstone, and silty to sandy limestone. All these members thin eastward and locally pinch out on the Sweetgrass arch. East of the arch, the middle member passes into highly fossiliferous black thin- to thick-bedded limestone typical of the middle member of the Piper Formation. The upper boundary of the Sawtooth Formation with the Rierdon Formation is sharp but apparently not disconformable except possibly on the Sweetgrass arch, where the top of the Sawtooth Formation bears chert pebbles and broken and worn belemnite guards (Cobban 1945, p. 1273; Weir, 1949, p. $551)$.

The Sawtooth Formation in southwestern Montana west of the Gallatin Range is also represented by three members which are well exemplified by the sequence on Indian Creek in the Madison Range (Imlay, Gardner, and others, 1948). At that place, the lower member rests on Triassic sandstone, is 79 feet $(24 \mathrm{~m})$ thick, and consists of interbedded green to brown siltstone and mudstone. The middle member is 67 feet $(20.4 \mathrm{~m})$ thick, consists of light-gray thin- to thick-bedded limestone and contains Gryphaea planoconvexa Whitfield. The upper member is 84 feet $(25.6 \mathrm{~m})$ thick and consists of interbedded papery siltstone, sandy siltstone, thin- to medium-bedded sandstone and thin- to thick-bedded sandy limestone. The siltstones are greenish gray to greenish brown, and the other rock types are gray to brown. This sequence contrasts with those in the Gallatin Range to the east, because it has no red beds in its upper and lower members (Imlay, Gardner, and others, 1948; Ruppel, 1972, p. A25; Moritz, 1951; Scholten and others, 1955, p. 367, 395, 396).

The westernmost sequence of the Sawtooth Formation in Montana, exposed in Little Water Canyon in the NE $1 / 4 \mathrm{SW}^{1 / 4} 4$ sec. 10 , T. 13 S., R. 10 W., Beaverhead County, is also divisible into three members. The lower member consists of 58 feet $(17.7 \mathrm{~m})$ of gray sandstone and sandy limestone that bears oysters and Camptonectes. The middle member consists of 120 feet $(36.5 \mathrm{~m})$ of fossiliferous gray calcareous shale and shaly limestone. The upper member consists of 14 feet $(4.2 \mathrm{~m})$ of interbedded oolitic limestone, fissile shale, and sandstone. Throughout southern Montana, exposures of the highest parts of the Sawtooth and the Piper Formations are overlain abruptly by an oolitic limestone bed at the base of the Rierdon Formation.

The base of the Sawtooth Formation in northwestern Montana is dated as late middle Bajocian (Imlay, Gardner, and others, 1948; Imlay, 1948, p. 19, pl. 5, figs. 15 ; $1967 \mathrm{~b}$, p. $35,90,93$, pl. 6 , figs. $1-3,7,8$ ) because of the presence of Chondroceras in close association with Stemmatoceras. The upper member is dated as early to middle Bathonian on the basis of the resemblance of the ammonite Paracephalites (Frebold, 1963, p. 5, 8-13, 27-29) to Arctocephalites and Cranocephalites of the arctic region. The middle shale member in the Sweet Grass Hills is dated as late Bajocian because it contains a pelecypod fauna identical with that in the Rich Member of the Twin Creek Limestone and the Firemoon Limestone Member of the Piper Formation (Imlay, 1967b, p. $35)$.

The Sawtooth Formation in southwestern Montana is dated only by the presence of the ammonites Sohlites and Parachondroceras in its middle member. Those ammonites in the Twin Creek Limestone are dated as latest Bajocian because they occur just above beds containing an association of Stemmatoceras, Spiroceras, and $\mathrm{Me}$ gasphaeroceras (Imlay, 1967b, p. 26, 27, 31).

The Rierdon Formation occurs widely throughout Montana and North Dakota except in the area of Belt Island, ranges in thickness from a featheredge to 180 feet $(55 \mathrm{~m})$ on the surface and to about 350 feet $(107 \mathrm{~m})$ in the subsurface, and consists mostly of calcareous gray shale and shaly to thin-bedded limestone. Shale predominates over limestone except in the Little Rocky Mountains and in the subsurface of south-central Montana. Some silty to sandy beds occur locally near the base of the formation near Belt Island. The basal unit in southernmost Montana from the Pryor Mountains westward consists of oolitic limestone that ranges from a few inches to about 30 feet $(9 \mathrm{~m})$ in thickness and represents the northern edge of the Canyon Springs Sandstone Member of the Sundance Formation. At the top of the Rierdon Formation in south-central Montana is an oolitic to sandy limestone that represents the northern extension of the Hulett Sandstone member of the Sundance Formation (Cobban, 1945, p. 1279, 1280; Imlay, 1945, p. 255; 1956a, p. 585-587; Imlay, Gardner, and others, 1948; J. A. Peterson, 1957, p. 408, 409; Richards, 1955, p. 40, 41). This limestone passes northward into chalky limestone at the top of the Rierdon Formation.

The Rierdon Formation extends from the Williston basin into southern Saskatchewan, where its upper part gradually becomes sandy to the north and northwest. In the subsurface of southern Saskatchewan, beds equivalent to this sandy upper part are called the Roseray Formation, which is much less extensive than the overlying and underlying subsurface formations. The Roseray consists mostly of even-bedded fine-grained sandstone but has some shaly beds near its tip and bottom (Christopher, 1974, p. $4,8,9,13,14,49,101)$. In those shaly beds are Foraminifera and ostracodes suggestive of ages intermediate between those of the Rierdon and Swift Formations of Montana (Brooke and Braun, 1972, p. 8, 13,20 , pls. 23,24 ).

The age of the Rierdon Formation in Montana has previously been considered as early Callovian (Imlay, 
Gardner, and others, 1948; Imlay, 1948, p. 14-16; $1953 \mathrm{a}$, p. $5-8 ; 1967 \mathrm{~b}$, p. 60 ). However, the lowermost part of the formation, which is characterized by Warrenoceras (formerly called Arcticoceras), should be of late middle to early late Bathonian Age on the basis of the close resemblance of Warrenoceras to Arcticoceras; the latter genus in East Greenland occurs below ammonites characteristic of the earliest Callovian Macrocephalites macrocephalus zone of Europe, according to Callomon (1959) and Birkelund and others (1971, p. 254). Also, most of the overlying beds, characterized by Kepplerites costidensus (Imlay), $K$. subitus Imlay, and $K$. aff. $K$. tychonis (Ravn), should be of latest Bathonian Age on the basis of comparisons with East Greenland. Only the uppermost part of the Rierdon Formation, characterized by Kepplerites maclearni Imlay in association with Lilloettia and Xenocephalites, is definitely early Callovian.

The age of the Rierdon Formation in southern Saskatchewan is apparently the same near its top as that of the Rierdon Formation of Montana, as shown by the presence of certain species of Kepplerites (Frebold, 1963, p. 23-26, pl. 10, fig. 3, pl. 12, fig. 1; Paterson, 1968, p. 35,36 , pl. 8, pl. 9, figs. 1-3).

The Swift Formation is more widespread than the underlying Jurassic formations. It ranges in thickness from a few feet to about 165 feet $(50 \mathrm{~m})$ in outcrops, and to more than 400 feet $(122 \mathrm{~m})$ in the subsurface. It consists of glauconitic sandstone, siltstone, and shale, and in surface sequences generally has a basal conglomerate. In the Sawtooth Range of northwestern Montana, the Swift is divisible into two transitional members. The upper member consists of thin-bedded, ripple-marked sandstone that contains partings of dark micaceous shale. The lower member consists of dark fissile micaceous noncalcareous shale. To the east, one or both members locally pinch out on the Sweetgrass arch but reappear farther east and gradually become much shalier eastward (Cobban, 1945, p. 1281-1286).

By contrast, the Swift Formation in southwestern, southern, and central Montana consists mainly of medium- to thick-bedded, glauconitic ripple-marked sandstone that persists as far east as the Big Snowy Mountains and the western part of the Pryor Mountains. Shale appears in these mountains at or near the base of the formation and gradually thickens eastward as the overlying sandstone thins (Imlay, Gardner, and others, 1948; Imlay, 1956a, p. 598, fig. 2 on p. 566; Moritz, 1951, p. 1804-1810).

The age of the basal beds of the Swift Formation varies considerably from place to place. In the Bearpaw and Little Rocky Mountains, the basal beds contain Quenstedtoceras (Lamberticeras) collieri Reeside, which by comparison with Europe should represent the latest Callovian. Directly above in the lower part of the formation is shale containing Cardioceras and Q. (Pavloviceras) of early Oxfordian Age. By contrast, in the Sawtooth Range of northwestern Montana, one specimen of Buchia concentrica (Sowerby) (USGS Mesozoic loc. 27058) of late Oxfordian Age was obtained from the base of the Swift Formation at the south end of Diversion Ridge south of the Sun River (NW1/4 SW1/4 sec. 12, T. 21 N., R. 9 W., Sawtooth Ridge Quad.). The same species was also obtained from sandy shale above a thick sandstone ledge in the upper part of the lower member of the Swift Formation on the north side of the Great Northern Railway about 3 miles $(4.8 \mathrm{~km})$ southwest of Marias Pass (Imlay, $1956 a$, p. 595).

The age of the upper part of the Swift Formation is uncertain because that part has not furnished any diagnostic fossils. It should be late Oxfordian to possibly early Kimmeridgian on the basis of its stratigraphic position.

The Morrison Formation in Montana rests conformably on the Swift Formation; ranges in thickness from 250 to 400 feet (76 to $122 \mathrm{~m}$ ); thins northward and disappears near the U.S.-Canadian border; consists mostly of clay shale, mudstone, dense limestone, and fine-grained sandstone; and at its top contains coal beds or carbonaceous beds (Cobban, 1945, p. 1268; Reeside, 1952, p. 25; Gardner and others, 1945; Hadley and others, 1945). The lowermost part of the Morrison Formation in western Montana should be of Kimmeridgian Age, as shown by the presence of the late Oxfordian to early Kimmeridgian Buchia concentrica (Sowerby) in the lower member of the underlying Swift Formation.

\section{SOUTHEASTERN IDAHO TO WESTERN SOUTH DAKOTA}

Marine Jurassic sequences in Wyoming and adjoining parts of Idaho and South Dakota (fig. 26) closely resemble the equivalent marine sequences in Montana and North Dakota at their top and bottom. At the top of the Jurassic, the Stump Sandstone, as exposed along the Idaho-Wyoming border, resembles the Swift Formation of western Montana and likewise passes eastward into shale (Redwater Shale Member of the Sundance Formation) that becomes shalier from the base upward and is predominantly shale east of the center of the Bighorn Basin. At the bottom of the Jurassic, the Gypsum Spring Formation (or Member of the Twin Creek Limestone), resembles the Nesson Formation of the Williston Basin. The lithologic units between the Stump and the Gypsum Spring show some resemblances to the units between the Swift and Nesson Formations but also show many differences.

The Gypsum Spring Formation, as originally defined by Love (1939, p. 42-46; Love and others, 1945), crops out in the northwestern part of the Wind River Basin 
west of long $108^{\circ} \mathrm{W}$., in the Teton and Gros Ventre areas of northwestern Wyoming, along the east and west sides of the Bighorn Mountains, in the northwestern part of the Black Hills in eastern Wyoming and western South Dakota, and around the northern parts of the Bighorn and Pryor Mountains in south-central Montana. Also, the equivalent Gypsum Spring Member of the Twin Creek Limestone occurs near the Wyoming-Idaho border and in north-central Utah.

In the Wind River Basin, the Gypsum Spring Formation ranges in thickness from 250 feet $(76 \mathrm{~m})$ to a featheredge and consists of three lithologic units. At the base is 20 to 40 feet $(6-12 \mathrm{~m})$ of red, slightly sandy siltstone that is overlain by $13-95$ feet $(4-30 \mathrm{~m})$ of massive white gypsum. At the top is $65-135$ feet $(20-41 \mathrm{~m})$ feet of interbedded red siltstone, red claystone, slabby limestone, ribboned chert-bearing dolomite or dolomitic limestone, and some gypsum (Love and others, 1945; Love and others, 1947; Pipiringos, 1968, p. D18). The Gypsum Spring Formation rests unconformably on the Nugget Sandstone and is overlain unconformably by the Piper Formation or by sandy oolitic beds at the base of the Sundance Formation.

In northwestern Wyoming east of the belt of thrust faulting, the Gypsum Spring Formation is essentially the same as in the Wind River Basin except that the massive gypsum is locally replaced on the surface by a brecciated unit consisting of red siltstone and limestone. Here, as in the Wind River Basin, the formation is underlain unconformably by the Nugget Sandstone and overlain unconformably by normal marine limestone equivalent to the Piper Formation of Montana and north-central Wyoming (Imlay, 1956b, p. 70; 1967b, p. 6, 7, 19; Foster, 1947, p. 1566; Wanless and others, 1955; Love and others, 1973).

Along the Idaho-Wyoming line and in north-central Utah, the Gypsum Spring member of the Twin Creek Limestone thickens westward from 12 to 400 feet (3.6 to $122 \mathrm{~m}$ ) and consists mostly of soft red to yellow claystone and siltstone that is interbedded with brecciated or vuggy limestone, or with chert-bearing limestone. The chert-bearing limestone thickens westward from a few feet to 70 feet $(21 \mathrm{~m})$. The brecciated limestone marks the position of thick masses of gypsum that are exposed about 32 miles $(51 \mathrm{~km})$ south-southeast of Jackson, Wyo. (Imlay, 1967b, p. 3, 17-19). Both lower and upper contacts of the member are sharp and presumably unconformable.

The Gypsum Spring Formation exposed along the flanks of the Bighorn Mountains and at the south end of the Bighorn Basin is similar lithologically to the formation in the Wind River Basin. Along the western flank of the mountains, the lower part of the formation consists of 25-100 feet (7.6-30.5 m) of massive white gypsum interbedded with some dark-red claystone, red siltstone, and gray limestone and overlain by $20-40$ feet $(6-12 \mathrm{~m})$ of dark-red claystone containing nodules and lenses of gypsum (Imlay, 1956a, p. 578). Along the eastern flank of the mountains, the lower $40-70$ feet $(12-21 \mathrm{~m})$ or more of the formation at more places consists of dark-red claystone and siltstone whose basal $10-50$ feet $(3-15 \mathrm{~m})$ contains some thin beds of gypsum, and some units of limestone breccia. At a few places, however, the basal beds consist of gypsum masses as much as 50 feet $(15 \mathrm{~m})$ thick (Hose, 1955, p. 52-54, 106, 107; Mapel, 1959, p. 28-32, pl. 5).

Along both flanks of the Bighorn Mountains, the upper part of the Gypsum Spring Formation consists mostly of 70-110 feet (21-33.5 m) of alternating units of limestone and dark-red claystone. The lower limestone unit consists mostly of gray, dense, shaly to thin-bedded limestone, is locally dolomitic, locally contains blocky chert, and in some beds contains external molds of tiny gastropods. The middle limestone unit is similar, but some beds are mottled pink to light green, and some bear many poorly preserved molds of pelecypods. The upper limestone unit is white, dense, and partly dolomitic, contains many beds and lenses of blocky chert, and forms a prominent ledge.

Above these limestone units on both flanks of the Bighorn Mountains is $10-50$ feet $(3-15 \mathrm{~m})$ or more of dark-red to pale-green siltstone and claystone (Imlay, $1956 \mathrm{a}$, p. 578 , Mapel, 1959, p. 29). These beds could represent the uppermost part of the Gypsum Spring Formation, but they are herein considered to represent the southern pinch-out of the upper red-bed member of the Piper Formation.

The Gypsum Spring Formation pinches out southward along the flanks of the Bighorn Mountains. It rests sharply and unconformably on the Triassic part of the Chugwater Formation (Hose, 1955, p. 53; Mapel, 1959 , p. 29; Imlay, 1956a, p. 579). The Gypsum Spring is overlain with angular unconformity by the lower part of the Sundance Formation south of a line extending northeast from Hyattville to Banner, Wyo. North of that line, it is overlain sharply by red claystone, herein assigned to the Piper Formation, which in turn is overlain sharply by gray sandstone or calcareous shale at the base of the Sundance Formation.

In the Black Hills area, the Gypsum Spring Formation is exposed only in the northwestern and northern parts, where it ranges in thickness from a featheredge to 125 feet; it attains its greatest thickness 10 miles northeast of Hulett, Wyo. At that place, its lowermost 75 feet $(23 \mathrm{~m})$ consists of massive gypsum and red claystone that rests sharply on the Triassic part of the Spearfish Formation. Its uppermost 50 feet $(15 \mathrm{~m})$ consists of interbedded limestone and red to gray claystone. Its upper contact is truncated and channeled in places by chert pebbles 
in the basal bed of the overlying Sundance Formation (Mapel and Bergendahl, 1956).

The upper part of the Gypsum Spring Formation is definitely of Jurassic age, on the basis of an association of the pelecypods Grammatodon, Myophorella, Opis (Trigonopis), and Quenstedtia with the gastropods Neritina, Tylostoma?, Nododelphinula?, Procerithium, and Lyosoma powelli White. These fossils were collected near Mill Creek, about 30 miles $(48 \mathrm{~km})$ northwest of Lander, Wyo., in a limestone bed about 20 feet $(6 \mathrm{~m})$ below the top of the formation, which is 224 feet $(68 \mathrm{~m})$ thick at that place (Love and others, 1945; Sohl, 1965, p. D10).

The Gypsum Spring Formation must be older than late Bajocian, because it underlies limestone of that age at Lower Slide Lake northeast of Jackson, Wyo. (Imlay, $1967 \mathrm{~b}$, p. 567, 577, 583; 1967b, p. 19, 33, 34, 59), and because the equivalent Gypsum Spring Member of the Twin Creek Limestone underlies limestone of late Bajocian Age and probably late middle Bajocian Age along the Idaho-Wyoming border (Imlay, 1967b, p. 28). The Gypsum Spring cannot be much older than late Bajocian, however, because it contains the gastropod Lyosoma powelli White, which occurs elsewhere mostly in upper Bajocian beds such as the Sliderock and Rich Members of the Twin Creek Limestone, the middle limestone member of the Piper Formation near Cody, Wyo., and the basal limestones of the Carmel Formation in central Utah. That species also occurs in somewhat younger Canyon Springs Sandstone Member of the Sundance Formation in the Bighorn Basin (Sohl, 1965, p. D5, D10, D11, D18). This evidence definitely favors an early to middle Bajocian Age for the Gypsum Spring Formation.

The Piper Formation is exposed in Wyoming along the northwest side of the Bighorn Basin from about 30 miles $(48 \mathrm{~km})$ southwest of Cody northward to the Montana border, in the northwestern part of the Wind River Basin nearly as far east as Lander, and along the flanks of the Bighorn Mountains north of Hyattville and Banner.

The Piper Formation exposed along the northwest side of the Bighorn Basin is of special interest because it consists of three members that are essentially identical with the three members of the Piper Formation in Montana (Imlay, Gardner, and others, 1948; Imlay, 1954, 1956a) and that rest directly on the Triassic part of the Chugwater Formation. The sequence exposed at Clarks Fork Canyon near the Montana border (Imlay, 1956a, p. 567 ) is essentially identical with that exposed 30 miles $(48 \mathrm{~km})$ southwest of Columbus, Mont. (Imlay, Gardner, and others, 1948). The sections exposed near Cody are essentially identical with the section exposed at Red Dome about 10 miles $(16 \mathrm{~km})$ southeast of Bridger, Mont., as well as closely similar to the Piper Formation in the subsurface in southern Montana and in the Williston basin (Nordquist, 1955, p. 99-103; Rayl, 1956, p. 3843; Imlay, Gardner, and others, 1948). The absence of the Gypsum Spring Formation along the northwest side of the Bighorn Basin is shown by the lack of any dolomitic beds, by the presence of much highly fossiliferous shaly limestone, and by the basal beds of the Piper Formation containing chert pebbles that are identical lithologically with chert beds or lenses in the Gypsum Spring Formation.

The Piper Formation elsewhere in north-central Wyoming is represented mainly by its upper red-bed member. In the Wind River Basin that member ranges from about 50 feet $(15 \mathrm{~m})$ to a featheredge, consists of red siltstone and claystone that becomes sandy near its eastern margin, and rests sharply on dolomitic beds or limestone at the top of the Gypsum Spring Formation (Love and others, 1945; Pipiringos, 1968, p. D10). The thickest section, exposed at Red Creek on the north side of the Wind River Basin, is of special interest because its base is marked by a chert conglomerate and at one place by a lens of pebbly limestone resembling that which occurs near the top of the middle limestone member of the Piper Formation along the western and southern sides of the Pryor Mountains, Mont. (Imlay, 1956a, p. 572-574).

Near the northern border of Wyoming, the upper red-bed member of the Piper Formation is represented by $10-86$ feet $(3-26 \mathrm{~m})$ of red claystone and some gypsum, which is beneath the Sundance Formation and above dolomitic beds typical of the Gypsum Spring Formation (Imlay, 1956a, p. 578). This claystone and gypsum unit crops out nearly continuously along the east side of the Bighorn Mountains north of Banner, and along the west side of the Bighorns north of Hyattville. It correlates with, and is continuous with, the upper redbed member of the Piper found in south-central Montana. This correlation is supported by comparisons between sequences at Sykes Mountain, Wyo., and Gypsum Creek, Mont. (Imlay, 1956a, p. 568, 569), and between sequences at Red Gulch, Wyo., and Lodge Grass Creek, Mont. (see table 1 for exact locations)(Imlay and others, 1948, columnar sections along line $D-D^{\prime}$; Mapel, 1959, pl. 5).

A basal unconformity is indicated by the presence of chert pebbles found as float near the base of 43 feet (13 m) of red claystone exposed at Lodge Grass Creek. This unconformity is further substantiated by the presence of dark-gray wind-polished chert pebbles at the base of 86 feet $(26 \mathrm{~m})$ of dark-red claystone that underlies the Sundance Formation near the east end of Sykes Mountain. These pebbles, collected by G. N. Pipiringos and the writer, consist of chert identical with that in the underlying Gypsum Spring Formation.

The middle limestone member of the Piper Formation in the Cody area contains the same characteristic mollusks that occur (1) in that member in Montana, (2) in 
the Rich Member of the Twin Creek Limestone near the Wyoming-Idaho border, and (3) on the north side of Lower Slide Lake, Teton County, Wyo., in 85 feet (26 $\mathrm{m})$ of shaly limestone that represents a thin eastern extension of the Rich Member (Imlay, 1956b, p. 70; 1967b, p. 31). Accordingly, on the basis of stratigraphic position, the upper red-bed member of the Piper Formation in the Bighorn Basin is correlated with the similar-appearing Boundary Ridge Member of the Twin Creek Limestone and with the eastward extension of that member at Lower Slide Lake and at Green River Lakes (Imlay, 1967b, p. 39). Similarly, the lower red-bed and gypsum member of the Piper Formation from the Cody area northward to Montana is correlated with the Sliderock Member of the Twin Creek Limestone and with eastern extensions of that member, which underlies the Rich Member (Imlay, 1967b, p. 27, 29, 30).

The Sundance Formation comprises seven members in the Black Hills region of Wyoming and South Dakota and in southeastern and central Wyoming as far north as the southern side of the Wind River Basin (Imlay, 1947; Pipiringos, 1953, 1957, 1968, p. D18-D24). These members, from the base upward, are Canyon Springs Sandstone, Stockade Beaver Shale, Hulett Sandstone, Lak, Pine Butte, Redwater Shale, and Windy Hill Sandstone. Regional unconformities occur at the base of the Canyon Springs, the Redwater, and the Windy Hill.

The Canyon Springs Sandstone Member represents the initial deposits of a transgressing sea. It rests on an irregular surface of erosion, varies considerably in thickness within short distances, becomes thicker to the south, and in many places is marked basally by pebbles, most of which consist of chert. As a lithologic unit it extends westward from the Black Hills to the Bighorn Mountains and northward from north-central Colorado to Sheep Mountain, about 18 miles $(29 \mathrm{~km})$ southeast of Lander, Wyo. Westward or northward from those mountains, it passes into sandy oolitic limestone that becomes less sandy away from the source.

In the Black Hills, the member is present only along the southern and western margins, ranges in thickness from a featheredge to 92 feet $(28 \mathrm{~m})$, and consists mostly of light-gray thin- to thick-bedded sandstone. Locally, the sandstone may be ripple marked, oolitic or massive, and red to white. Locally, the member includes beds of maroon to gray shale or siltstone (Imlay, 1947, p. 247251; Gott and Schnabel, 1963, p. 139-140; Mapel and Bergendahl, 1956, p. 87).

In southern Wyoming, the Canyon Springs Sandstone Member consists of a lower unit of yellowish-white massive or crossbedded sandstone overlain by a unit of ripple-marked, oolitic fossiliferous sandstone (Pipiringos, 1968, p. D18-D21). It thickens southward from a featheredge to 65 feet $(20 \mathrm{~m})$ in Wyoming and to about
165 feet $(50 \mathrm{~m})$ in north-central Colorado (Pipiringos and others, 1969, p. N10).

The Canyon Springs Sandstone Member is probably of Bathonian Age because it contains Warrenoceras (USGS Mesozoic locs. 20496, 20497, 20503) in the Hartville uplift of southeastern Wyoming and in the type section of the member (USGS Mesozoic loc. 20337) about 4 miles west of Horton, Wyo. (Imlay, 1947, p. 250; 1953a, p. 17, 22). Warrenoceras, formerly classified with Arcticoceras (Imlay, 1953a, p. 5, 19-23), is either a subgenus of Arcticoceras or a provincial time equivalent. Its resemblance to Arcticoceras suggests that it is of about the same age and probably early late or late middle Bathonian on the basis of the ammonite sequence in East Greenland (Callomon, 1959). Similarly, a late Bathonian Age is indicated by the presence of Warrenoceras in an oolitic limestone unit at the base of the Sundance Formation at Red Creek (USGS Mesozoic loc. 21635) in the Wind River Basin and in the Cody area of the Bighorn Basin (USGS Mesozoic loc. 17106). This oolitic limestone unit correlates, therefore, both stratigraphically and faunally with the Canyon Springs Sandstone Member.

The Stockade Beaver Shale Member of the Sundance Formation grades into the adjoining members and passes laterally southward entirely into the underlying Canyon Springs Sandstone Member in south-central Wyoming. In the Black Hills, the shale member consists of 5-90 feet $(1.5-2.7 \mathrm{~m})$ of greenish-gray, fissile, calcareous shale that includes some limestone beds and nodules near its base and some siltstone and sandstone near its top (Imlay, 1947, p. 251, 252). In south-central Wyoming, the member consists of $12-110$ feet $(3.6-34 \mathrm{~m})$ of greenish-gray shale and siltstone (Pipiringos, 1968, p. D21). In the Bighorn Basin, the shale member consists mostly of soft, gray fissile calcareous shale that is locally sandy toward its top, ranges in thickness from a featheredge to about 80 feet $(24 \mathrm{~m})$, is thickest in the northern part of the basin, and contains an abundance of Gryphaea, which genus is uncommon in the shale member in the Black Hills (Imlay, 1956a, p. 588-595).

The Hulett Sandstone Member of the Sundance Formation grades into the adjoining members. It consists mostly of light-gray, fine-grained, calcareous, fossiliferous, thin- to thick-bedded, ripple-marked, slightly glauconitic sandstone that is interbedded with some greenish-gray shale and siltstone. In the Black Hills, the thickness of the Hulett Sandstone Member ranges from 20 to 120 feet ( 6 to $36.5 \mathrm{~m}$ ) (Imlay, 1947, p. 255; Robinson and others, 1964, p. 15); in southern Wyoming, from 4 to 40 feet (1.2 to $12 \mathrm{~m}$ ) (Pipiringos, 1968, p. D22); along the east side of the Bighorn Mountains, from 27 to 70 feet $(8$ to $21 \mathrm{~m}$ ) (Mapel, 1959, p. 33; Hose, 1955, p. 106; J. A. Peterson, 1954a, p. 477); along the west side of the Bighorn Mountains, from 16 to 104 feet (5 to $32 \mathrm{~m}$ ); and around the Pryor Mountains and the northern end of the 
Bighorn Mountains, from 0 to 48 feet ( 0 to $14.6 \mathrm{~m}$ ) (Imlay, 1956a, p. 589). Farther west, the Hulett Sandstone Member is possibly represented by about 8 feet of sandstone and oolitic limestone at the top of the "Lower Sundance" Formation at Red Creek in the Wind River Basin (T. 6 N., R. 3 W.) (Love and others, 1945). It is also possibly represented at the same stratigraphic position in the gorge of the Shoshone River west of Cody by 24 feet $(0.8 \mathrm{~m})$ of gray sandstone and by the overlying 14 feet $(4.2 \mathrm{~m})$ of sandy claystone and sandy oolitic limestone (Imlay, 1956a, p. 592).

The Lak Member of the Sundance Formation grades into the adjoining members. In the Black Hills, it consists of $25-100$ feet $(7.6-30.5 \mathrm{~m})$ of dark-brownish-red to pink to yellowish-gray, very fine grained, generally massive sandstone and sandy siltstone (Imlay, 1947, p. 257; Robinson and others, 1964, p. 15; Gott and Schnabel, 1963, p. E141, E142). In southeastern Wyoming near Glendo, the member consists of 50 feet $(15 \mathrm{~m})$ of finegrained nonglauconitic sandstone that is commonly red (Love and others, 1949). In south-central Wyoming, the member consists of 7-70 feet (2-21 m) of reddish-brown siltstone, sandy siltstone, and silty sandstone that changes southward to pale gray or pale yellow near Medicine Bow and Rawlins (Love and others, 1945; Love and others, 1947; Love and others, 1949; Pipiringos, 1968, p. D22, D23). The Lak Member pinches out to the west in the Powder River Basin and to the north about 20 miles (32 $\mathrm{km}$ ) west of Lander. It is absent around the Bighorn Mountains and the Bighorn Basin, along the north side of the Wind River Basin, and apparently also at Green River Lakes at the northwest end of the Wind River Mountains.

The Pine Butte Member of the Sundance Formation in southern Wyoming (Pipiringos, 1968, p. D22-D23) consists of 60 feet or less of greenish-gray to white, thinbedded, glauconitic, limy, ripple-marked sandstone that is interbedded with gray to green limy siltstone and claystone and that near its middle generally contains 1-18 feet of red sandstone and siltstone. Surfaces of sandstone beds are characterized by the presence of raised furrowed trails (Gyrochorte?). Marine fossils are not common in the Pine Butte Member, but Pentacrinus columnals, echinoid spines, and pelecypods have been found. The member passes southward into north-central Colorado, where it intertongues with the underlying Canyon Springs Sandstone Member (Pipiringos, 1972, p. 27). It thins northward in Wyoming and pinches out about 17 miles $(27 \mathrm{~km})$ southeast of Lander. It is overlain sharply by the Redwater Shale Member and is locally truncated by that member. The contact is marked by the presence of many belemnites in the basal beds of the Redwater Shale Member and by their absence in the Pine Butte Member. Sandstone beds at or near the base of the Red- water Shale Member can be distinguished from sandstone beds in the Pine Butte Member by the presence of belemnites and the absence of furrowed trails.

The Pine Butte Member in the Black Hills area was identified by G. N. Pipiringos in 1964 while on a field trip with the writer. At that time he noted that a sandstone unit 5-32 feet $(1.5-10 \mathrm{~m})$ thick at the base of the Redwater Shale Member (Imlay, 1947, p. 245, 260, 267-273; Robinson and others, 1964 , p. 16-18) had all the characteristics of the Pine Butte Member of southern Wyoming. It graded downward into or was conformable with the Lak Member, contained raised furrowed trails, did not contain belemnites, and was overiain sharply by siltstone containing many belemnites. He found that the thickest section of the Pine Butte Member was exposed northeast of Spearfish, S. Dak., in the standard reference section of the Sundance Formation (Imlay, 1947, p. 245). The characteristics of the member at that locality, as shown in a diagram by Pipiringos (1968, p. D12), are described as follows:

\section{Stratigraphic section of the Pine Butte Member of the} Sundance Formation

[Located in the Jolly Quadrangle, about three-quarters of a mile $(1.2 \mathrm{~km})$ northeast of Spearfish, S. Dak., in the SE1/4NW1/4 SE $1 / 4 \mathrm{SE}^{1 / 4}$ sec. 3, T. 7 N., R. 2 E. Measured by G. N. Pipiringos, September 1964 ]

Sundance Formation:

Redwater Shale Member (in part):

8. Siltstone, medium-gray, clayey, sandy, calcareous,, glauconitic, fossiliferous; basal few inches contains abundant belemnites; makes slope; basal contact is sharp; no belemnites were found below

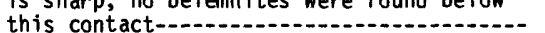
Partial thickness of Redwater Shale Member

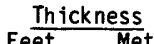

\section{Sha}

J-4 unconf ormity

Pine Butte Member:

7. Siltstone, greenish-gray, clayey, sandy, and some thin beds of light-olive-gray silty clay shale; unit makes slope-..---

6. Sandstone, green ish-gray, weathers dusky yellow at the top; very fine grained, calcareous, clayey; contains worm borings filled with gray clay; iron oxide nodules about one-half inch $(1.3 \mathrm{~cm})$ in diameter near middle of unit, and some olive gray mudstone partings; unit makes rounded ledge-.

5. Sandstone, siltstone, and clay shale; the sandstone is light gray, very fine grained, silty, clayey, structureless, calcareous, finely glauconitic, fossiliferous, and makes weak ledge in middle; upper and lower parts of unit consist of about equal parts of light-greenish-gray clay shale and light-gray clay siltstone-..-...-...-...-

4. Sandstone, light-gray, very fine grained, calcareous; middle part makes rounded weak ledge overlain by a 1 -foot bed of light-green ish-gray, noncalcareous clay shale; upper and lower parts of unit are soft, structureless, clayey, and make

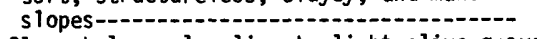

3. Clay shale, pale-olive to light-olive-gray; contains a zone of pale-red clayey siltstone about 2-3 feet above base;

siltstone about 2-3 feet above base;
unit makes slope--. 


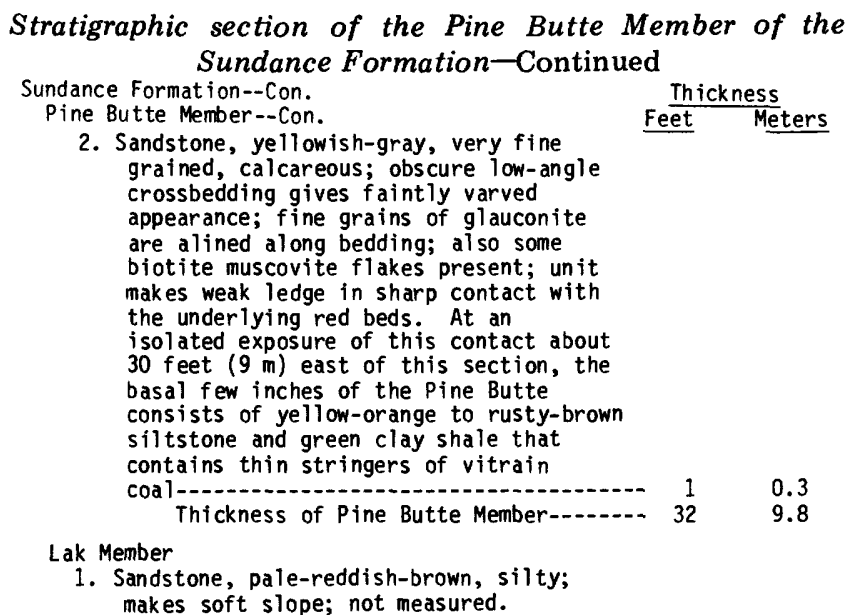

The Pine Butte Member is considered to represent the upper part of the "Lower Sundance" Formation on the basis of its conformable relationship with the underlying member, its unconformable relationship with the overlying Redwater Shale Member, and the presence of the pelecypods Vaugonia conradi (Meek and Hayden) and Quenstedtia cf. Q. sublaevis (Meek and Hayden). These species were originally described from the various members of the "Lower Sundance" Formation in the Black Hills and are widely distributed in the western interior region, but they are not known from the Redwater Shale Member or its equivalents. In addition, in the section of the Pine Butte Member described above, the fossiliferous ledge in the middle of unit 5 contains Myophorella montanaensis Meek (USGS Mesozoic locs. 29128 and 29518). In Montana this species ranges from the middle limestone member of the Piper Formation into the lower part of the Rierdon Formation; along the Idaho-Wyoming border it ranges from the Sliderock Member of the Twin Creek into the Watton Canyon Member of the Twin Creek; and in Utah it occurs in the lower part of the Carmel Formation (Imlay, 1964d, p. C4, C31-C33; 1967b, p. 82).

The Redwater Shale Member of the Sundance Formation in south-central Wyoming, as defined by Pipiringos (1968, p. D23), consists of four units, which from the base to top are alternately siltstone and shale. Of these, the siltstone units contain beds of shelly coquinoid sandstone or limestone, and the shale beds contain limestone concretions. To the northwest, the upper two units pass into cliff-forming sandstone, and the lower two units pass into somewhat softer silty or clayey sandstone. This twofold division exists in the Bighorn Mountains and Bighorn Basin and in west-central Wyoming west of Sheep Mountain, which is about 20 miles (32 km) southeast of Lander (Pipiringos, 1968, fig. 2 on p. D3). The Redwater Shale Member ranges in thickness from about 75 to 165 feet $(23$ to $50 \mathrm{~m})$ in the Black Hills, from 50 to 120 feet (15 to $37 \mathrm{~m}$ ) in southern Wyoming, from 130 to 160 feet
$(40$ to $49 \mathrm{~m}$ ) in the Wind River Basin, and from 120 to 175 feet $(37$ to $53 \mathrm{~m}$ ) in the Bighorn Basin and Bighorn Mountains.

The age of the Redwater Shale Member is probably entirely early to early middle Oxfordian, on the basis of the presence of the cardioceratid ammonites Cardioceras and Goliathiceras throughout most of the member. Lowermost occurrences range throughout the basal 15 feet $(4.5 \mathrm{~m})$ (Mesozoic locs. 19359, 2434, 24736). The uppermost occurrence is 20 feet $(6 \mathrm{~m})$ below the top of the member where it is 230 feet $(70 \mathrm{~m})$ thick on Little Sheep Mountain southeast of Lovell, Wyo. (Mesozoic loc. 26717). At Horse Creek near the northwest end of the Wind River Basin (Love and others, 1945), Cardioceras occurs 25 feet $(7.6 \mathrm{~m})$ below the top of the member where the member is 130 feet $(40 \mathrm{~m})$ thick (Mesozoic loc. 19398). On the Johnson Ranch about 17 miles $(27 \mathrm{~km})$ southeast of Lander, Wyo., Cardioceras occurs 29 feet $(9 \mathrm{~m})$ below the top of the member, which is 127 feet $(39 \mathrm{~m})$ thick (Mesozoic loc. 28400).

The Windy Hill Sandstone Member of the Sundance Formation in southern Wyoming (Pipiringos, 1968, p. D23-D25) consists of 5-57 feet $(1.5-17 \mathrm{~m})$ ledge-forming sandstone that is yellowish-gray, limy, ripple marked, weathers bright yellow to orange to brown, and contains a few specimens of Ostrea and Camptonectes. Its upper part grades into and locally intertongues with the Morrison Formation. Its basal part rests sharply on and locally truncates the Redwater Shale Member. It pinches out northwestward a little west of Hanna, Utah, and a little west of Lander, Wyo. (G. N. Pipiringos, oral commun., 1974). It is not present along the north side of the Wind River Basin, or around the Bighorn Mountains, or anywhere in northwestern Wyoming or in Montana.

The Windy Hill Sandstone Member is represented in the Black Hills area, according to Pipiringos (1968, p. D24), by a bright yellow sandstone that is lithologically similar to the typical exposures of the member elsewhere and that occupies the same stratigraphic position. These similarities were recognized previously by Mapel and Pillmore (1963, p. N16) before the member was named. For mapping purposes, they placed the yellow sandstone in the top of the Redwater Shale Member because it was too thin to map separately but formed an easily recognizable formation boundary. They did not see any evidence that the yellow sandstone might rest unconformably on the underlying shale. They did note, however, that the yellow sandstone contained some thin seams of chert and some thin beds of gypsum and that locally beds of gypsum occurred both above and below the sandstone.

The exact age of the Windy Hill Sandstone Member is not known. Nonetheless, its unconformable relationship with the underlying dated Redwater Shale Member 
in southern Wyoming suggests that it is younger than early Oxfordian and probably represents a small part of middle Oxfordian time. Its absence north of central $\mathrm{Wy}$ oming may be due to distance away from a source of sand, to its merging northward into deeper water marine deposits, or to both.

The Twin Creek Limestone, exposed along the Wyoming-Idaho border in an area of thrust faulting and in north-central Utah, has recently been described in detail and correlated member by member with marine beds elsewhere in the western interior region (Imlay, 1967b, p. 2-52). As this information is readily available, only the most essential is discussed here and is shown on figures 26. 27, and 28.

East of the area of extensive thrust faulting, beds equivalent to the Twin Creek Limestone crop out in the south-central part of Yellowstone National Park, near the Gros Ventre River northeast and east of Jackson (Foster, 1947, p. 1565, 1566; Imlay, 1956b; 1967b, p. 6), and at the west end of the Wind River Mountains near Green River Lakes (Richmond, 1945). In those areas, however, the marine Jurassic beds above the Gypsum Spring Formation are referred to the Sundance Formation because they are much thinner, much less calcareous, and more fossiliferous than the typical Twin Creek Limestone. Nonetheless, the lower part of the Sundance Formation in those areas consists of units that are lithologically, stratigraphically, and faunally equivalent to the Sliderock, Rich, Boundary Ridge, Watton Canyon, and Leeds Creek Members of the Twin Creek Limestone. Also, the first three members are not represented in the typical Sundance Formation farther east but are represented in the Piper Formation.

Thus, at Bacon Ridge, in secs. 13 and 14, T. 40 N., R. 111 W., Teton County, Wyo., 125 feet $(38 \mathrm{~m})$ of soft limy shale resembles both the Stockade Beaver Shale Member of the Sundance Formation and the Leeds Creek Member of the Twin Creek Limestone. Above this shale is 8 feet $(2.4 \mathrm{~m})$ of gray, fine-grained, hard, ripplemarked sandstone (Love and others, 1948, p. 48) that could be interpreted either as an extension of the Hulett Sandstone Member of the Sundance or of the Giraffe Creek Member of the Twin Creek Limestone. Next higher is 4 feet of soft, gray, nonglauconitic siltstone that most probably is the bleached lateral extension of the Preuss Sandstone or of the Lak Member of the Sundance Formation. Sharply overlying is highly glauconitic sandstone and shale typical of the Stump Sandstone or of the "Upper Sundance" Formation in nearby parts of Wyoming.

Also, a section measured by G. N. Pipiringos and the writer north of Lower Slide Lake (see below) contains five well-exposed units that greatly resemble the named members of the Twin Creek Limestone from the Slide- rock Member to the Leeds Creek Member. The uppermost of these, the Leeds Creek equivalent, also resembles the Stockade Beaver Shale Member of the Sundance Formation lithologically and faunally. This unit is overlain by 41 feet $(12.5 \mathrm{~m})$ of partially covered beds (units 23 to 30 in the section below), which were exposed in a trench made when the section was measured. These beds extend up to an unconformity at the base of the "Upper Sundance" formation (equivalent to the Stump Sandstone, or the Redwater Shale Member of the Sundance):

Stratigraphic section of the Sundance Formation and its members with its Twin Creek Limestone member equivalents and Gypsum Spring Formation

[Exposed on the north side of Lower Slide Lake in sec. 4, T. $42 \mathrm{~N}$., R. 114 W., Teton County, Wyo.]

Sundance Formation:

Redwater Shale Member:

35. Sandstone, gray, fine- to medium-grained, limy, giauconitic; basal 20 feet pebbly; overiain by Morrison(?) and Cloverly Formations; estimated thickness---..--

34. Sandstone, green, fine-grained, glauconitic; forms vertical reentrant under cliff..--

33. Sandstone, dark-gray to black, clayey to silty, highly glauconitic; forms slope---

32. Siltstone, dark-gray, clayey, glauconitic;
contains 4-inch $(10-\mathrm{cm})$ bed of siliceous contains $4-$ inch $(10-\mathrm{cm})$ bed of siliceous
nodules; contains many belemnites and nodules; contains many belemnites and
ostracodes near base--

31. Bentonite, yellowish-white to gray, fissile Redwater Shale Member-... Pine Butte(?) Member

30. Sandstone, greenish-gray, very fine grained, limy, ripple-marked; forms prominent ledge-1.

29. Sandstone, green ish-yellow, soft, silty;
includes some thin sandstone beds that includes some thin sandstone beds that

28. Sandstone, greenish-gray, very fine grained, platy, nonglauconitic; forms ledge-...--

27. Siltstone, pink, soft-a

26. Sandstone, greenish-gray, very fine grained, potal Pine Butte(?) Member-.. Lak Member:

25. Siltstone, greenish- to yellowish-gray, sandy, soft-ar

24. Siltstone, reddish-pink, sandy, soft--..-.

23. Siltstone, green ish- to yellowish-gray, sandy, soft- Member.

Stockade Beaver Shale Member:

22. Shale, limy; several thin beds of limestone 30-40 feet (9-12 m) above base. Contains Cadoceras and Gryphaea nebrascensis--.-. nebrascensis-1 Total Stockade Beaver Shale Member-.--

Canyon Springs Sandstone Member:

21. Limestone, yellowish-gray, oolitic, thin-

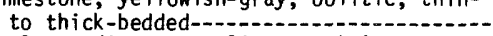

20. Shale, medium-gray, limy; contains

19. Shale, medium-gray, limy, and thin beds of soft brownish-gray iimestone; contains Warrenoceras--.

18. Limestone, medium-gray, oolitic, massive--
17. Limestone, yellowish-gray, crumbly, medium-

16. Limestone, yellowish-gray, oolitic, mediumto thin-bedded-..-gray, oolitic, mediumTotal Canyon Springs Sandstone

Boundary Ridge Member of Twin Creek Limestone equivalent:

15. Limestone, yellowish-gray, soft, shaly-...

14. Limestone, olive-green to gray, soft, shaly--.-.-

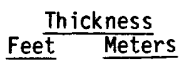

$100 \pm \quad 30.4+$

$17 \quad 5.2$

$7 \quad 2.1$

$7 \quad 2.1$

$\begin{array}{cc}1 & 0.3 \\ 132+ & 40.2+\end{array}$

$2 \quad 0.6$

9.5

2.9

0.3

10.3

$\begin{array}{cc}1 & 0.3 \\ 14.5 & 4.4\end{array}$

$5 \quad 1.5$

$19.5 \quad 5.9$

$\begin{array}{lr}12 & 3.7 \\ 36.5 & 11.1\end{array}$

163

49.7

$\begin{array}{ll}7 & 2.1\end{array}$

$20 \quad 6.1$

$10 \quad 3.0$

$3.5 \quad 1.1$

$4.5 \quad 1.4$

$12 \quad 3.7$

$\begin{array}{ll}57 & 17.4\end{array}$

$3.5 \quad 1.1$

$1.5 \quad 0.5$ 
Stratigraphic section of the Sundance Formation and its members with its Twin Creek Limestone member equivalents and Gypsum Spring Formation-Continued

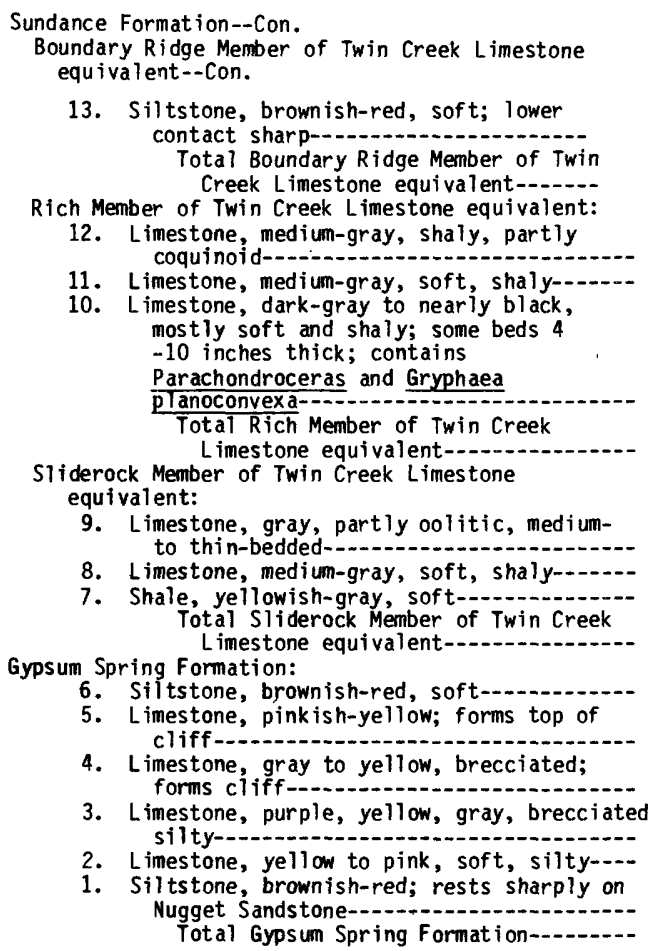

\begin{tabular}{cc}
\multicolumn{2}{c}{ Thickness } \\
Feet & Meters \\
& \\
$33-43$ & $10.1-13.1$ \\
$38-48$ & $11.6-15.6$ \\
& \\
23 & 7.0 \\
27 & 8.2
\end{tabular}

$\begin{array}{cc}35 & 10.7 \\ 85 & 25.9\end{array}$

The Preuss Sandstone crops out in the same area as the Twin Creek Limestone, thickens westward from 70 feet $(21 \mathrm{~m})$ or less to about 1,300 feet $(400 \mathrm{~m})$, and consists mostly of pale- to dull-red, even-grained, finegrained, plane-bedded, locally ripple-marked sandstone. In addition, its lower part contains considerable bedded salt along the Idaho-Wyoming border, and a marine limestone member attains nearly 200 feet $(61 \mathrm{~m})$ in the area east of Blackfoot and Idaho Falls, Idaho. The formation grades downward into the Twin Creek Limestone and is overlain sharply and unconformably by the Stump Sandstone or by the Curtis Formation in Utah (Mansfield, 1927, p. 98, 99, 338-340; Baker, 1947; Thomas and Krueger, 1946, p. 1277, 1278; Imlay, 1952b).

A marine origin for the Preuss Sandstone is shown by the presence of salt, marine limestone, even grain size, even bedding and oscillation ripple marks. Marine fossils, including pelecypods, gastropods, and corals, are common only in exposures east of Blackfoot and Idaho Falls, Idaho, but oysters and crinoid columnals are found as far east as sec. 17, T. 31 N., R. 119 W., about 7 miles $(11 \mathrm{~km})$ southwest of Afton, Wyo.

The age of the Preuss Sandstone must be mostly middle Callovian, because it conformably overlies beds of early Callovian Age and unconformably underlies beds of early Oxfordian Age. The Wolverine Canyon Limestone Member of the Preuss (Imlay, 1952b, p. 1742) cannot be much younger than early Callovian, as it contains the coral Actinastrea hyatti (Wells) (Imlay, 1967b, p. 35) and the gastropod Lyosoma cf. L. powelli White (Sohl, 1965 , p. D11, D17, D18, pl. 2, fig. 4). Of these fossils, $A$. hyatti (Wells) has been recorded elsewhere only in beds of late Bajocian Age. Lyosoma cf. L. powelli White has been recorded from the Hulett Sandstone Member of the Sundance Formation in the Badwater area, Fremont County, Wyo., and from the Rierdon Formation in northern Yellowstone National Park, Mont.

The term Stump Sandstone has been applied to the uppermost Jurassic marine sandstone and sandy shale overlying the Preuss Sandstone in westernmost Wyoming, southeastern Idaho, and parts of north-central and northeastern Utah. Within that area, the Stump Sandstone ranges in thickness from 130 to 500 feet (40 to 152 $m)$. It is thickest in southeastern Idaho and thins irregularly northward and eastward (Mansfield and Roundy, 1916 , p. 76, 81; Mansfield, 1927, p. 99-101; 1952, p. 38; Gardner, 1944; Rubey, 1958; Cressman, 1964, p. 52, 53; Staatz and Albee, 1963, 1966; Pampeyan and others, 1967; Albee, 1968; Schroeder, 1969; Thomas and Kreuger, 1946, p. 1269, 1276, 1278, 1285).

The Stump Sandstone exposed along the Idaho-Wyoming border consists mostly of sandstone and sandy shale units and has not hitherto been considered divisible into members. As described by Mansfield (1927, p. 99-101), the sandstone is fine to medium grained, thin bedded to massive, ripple marked, calcareous, glauconitic, greenish-gray to gray, and locally crossbedded. Interbedded with the sandstone are some beds of calcareous, greenish-gray shale and sandy siltstone and some beds of glauconitic, greenish-gray, shaly, thin-bedded to massive limestone that may be sandy, oolitic, and ripple marked. Apparently all gradations between sandy limestone and calcareous sandstone are represented. The base is generally marked by a bed of fossiliferous coarsegrained sandstone or grit, according to Mansfield (1927, p. 99-101).

Recent field studies by George Pipiringos and the writer have shown that the Stump Sandstone exposed along the Idaho-Wyoming border includes members that are lithologically, stratigraphically, and faunally equivalent to the Curtis Formation of Utah and to the younger sandy facies of the Redwater Shale Member of the Sundance Formation of northern Utah and western Wyoming. As the Stump Sandstone at present is the most practical unit for mapping purposes, it is herein retained as a formation and is divided into the Curtis Member below and the Redwater Member above. This terminology applies to an area extending eastward from the Blackfoot Mountains east of Blackfoot and Idaho Falls in Idaho 
to the Wyoming and Hoback Ranges in western Wyoming; extending southward from the Teton Range in the western part of the Jackson Hole area at least as far as Woodruff and Peoa in north-central Utah, Evanston in southwestern Wyoming; and eastward from Peoa along the length of the Uinta Mountains.

The Curtis Member near the Wyoming-Idaho border ranges in thickness from 30 to at least 395 feet (9 to 120 $\mathrm{m})$, thins eastward and northward, and extends considerably farther south and southwest than the Redwater Member. Its lower contact with the underlying Preuss Sandstone is sharp on McCoy Creek, Idaho (sec. 6, T. 37 N., R. 46 E.), is gradational elsewhere within a few inches or a few feet, and is not marked by pebbles or by irregularities suggestive of a disconformity. The Curtis Member is distinguished from the Preuss Sandstone by a fairly abrupt color change upward from red to gray and by the presence of tracks and trails in abundance. These differences probably indicate a slight deepening of the sea that caused a change from hypersalinity to almost normal marine salinity. The change must have been very slight because the Curtis Member on Tincup Creek in Idaho (sec. 9, T. 5 S., R. 46 E., and sec. 10, T. 5 S., R. 45 E.) and on Fish Creek in Wyoming ( $\mathrm{SE}^{1 / 4} \mathrm{sec}$. 32, T. $30 \mathrm{~N}$., R. 118 W.) contains a unit of red sandstone and siltstone that is nearly identical lithologically with red units in the Preuss Sandstone.

The Redwater Member of the Stump near the IdahoWyoming border is well developed along both sides of the Snake River and farther east, ranges in thicknesses from a featheredge to 175 feet $(0-53 \mathrm{~m})$, and thins eastward and southward. It differs from the underlying Curtis Member by being much more fossiliferous, by containing belemnites and ammonites, by its shale being chunky instead of fissile, by being more glauconitic, and by its bedding surfaces being marked only rarely by tracks and trails. Unlike the Curtis Member, it does not bear claypebble impressions or cube-shaped imprints indicative of salt crystals. Its upper and lower contacts are marked by sharp lithologic changes that reflect unconformities. It has not yet been identified lithologically or faunally in southeastern Idaho or along the Idaho-Wyoming border south of the Caribou Range, which is just south of the Snake River. The Redwater Member is definitely not present in the type area of the Stump Sandstone cut or near Stump Peak.

The Redwater Member of the Stump Sandstone in southeastern Idaho and western Wyoming is correlated with the Redwater Shale Member of the Sundance Formation elsewhere because it contains belemnites in fair abundance from bottom to top (USGS Mesozoic locs. $12125,112126,16024,16028,17897,18183,18185$, $30393,18187,30395)$ and contains Cardioceras near its base at Telephone Creek, Wyo. (USGS Mesozoic loc.
16024), and at McCoy Creek, Idaho (Mesozoic loc. 17897), as well as in the lower part of its upper third at McCoy Creek (USGS Mesozoic loc. 30395). In addition, the formation at its base at Telephone Creek contains the pelecypods Vaugonia quadrangularis (Hall and Whitfield) and Oxytoma wyomingensis (Stanton) along with Cardioceras and belemnites (USGS Mesozoic loc. 16024) and at its top on McCoy Creek contains $O$. wyomingensis (Stanton) (USGS Mesozoic loc. 12125). The presence of these bivalves is important for correlation purposes because they occur elsewhere in the Redwater Shale Member of the Sundance Formation and in the Swift Formation, but they do not occur in older formations or members. The presence of Cardioceras shows that the Redwater Member is of early to early middle Oxfordian Age.

These facts show that the Curtis and Redwater Members of the Stump Sandstone were deposited in different seas that covered somewhat different areas, that erosion took place at the end of Curtis deposition and again after Redwater deposition, and that the present changes in thicknesses of the members is in part depositional as well as erosional.

The continental Morrison Formation in Wyoming, western South Dakota, and northernmost Utah and Colorado was deposited conformably on the Windy Hill Sandstone Member or on the Redwater Shale Member of the Sundance Formation. The Morrison attains thicknesses of 125-370 feet $(38-113 \mathrm{~m})$ in Wyoming and South Dakota and more than 800 feet $(244 \mathrm{~m})$ in northeastern Utah (Reeside, 1952, p. 24, 25; Craig and others, 1955, p. 159; Hansen, 1965, p. 85). Westward increases in thickness and certain changes in lithologic characteristics (Mirsky, 1962, p. 1675-1678) indicate that its source was to the west in Utah and Idaho. On the basis of fresh-water mollusks, it should be older than the Purbeck Beds of England (Yen, 1952, p. 31-34), which are now correlated with the upper part of the upper Tithonian (Yen, 1952, p. 31-34). On the basis of vertebrates and stratigraphic position, its age should be mostly Kimmeridgian (Imlay, 1952a, p. 953, 958; Reeside, 1952, p. 25). The basal beds of the Morrison, however, where they overlie the Redwater Shale Member, should be of late Oxfordian Age, as shown by the presence of Cardioceras and Quenstedtoceras throughout most of that member.

The continental Nugget Sandstone, as exposed in southeastern Idaho, western and central Wyoming, and north-central Utah, lies unconformably below the Gypsum Spring Formation, or the Gypsum Spring Member of the Twin Creek Limestone, of early to early middle Bajocian Age. Regionally, the Nugget rests unconformably on beds of Late Triassic age (Reeside, 1957, p. 1480, 1482; Pipiringos, 1968, p. D16; Pipiringos and 
O'Sullivan, 1978). It consists characteristically of red to brown, or yellowish-gray to white, massive highly crossbedded sandstone, but in some places it includes considerable even-bedded, thin-bedded, ripple-marked, red to gray sandy shale, silty sandstone, and siltstone, which are most common in its lower 200 feet (Mansfield, 1927, p. 96; Love and others, 1945; Pipiringos, 1968, p. D17; Poole and Stewart, 1964, p. D38; Cressman, 1964, p. 45; Rubey, Oriel, and Tracey, 1975, p. 4). The Glen Canyon Sandstone, as exposed in the Uinta Mountains of northeastern Utah and northwestern Colorado, occupies the same stratigraphic position as the Nugget Sandstone, is bounded by the same unconformities, and is reddish in the western part of the Uinta Mountains and white in the eastern part. Both of these formations on the basis of stratigraphic position could be of Late Triassic and (or) Early Jurassic age.

\section{NORTHERN UTAH TO NORTHERN COLORADO}

The Twin Creek Limestone and Preuss Sandstone in the Wasatch and Uinta Mountains of north-central Utah are nearly identical lithologically with the same formations exposed farther north, along the Wyoming-Idaho border. Eastward in the Uinta Mountains, however, the lower five members of the Twin Creek Limestone gradually wedge out from the base upwards (see fig. 27). Thus, the Gypsum Spring Member wedges out between Oakley and the Duchesne River; the Sliderock Member, between Lake Fork and Whiterocks River canyon; the Rich Member, between Whiterocks River canyon and Vernal; and the Boundary Ridge and Watton Canyon Members, eastward near Vernal. The two uppermost members of the Twin Creek Limestone change markedly east of Lake Fork into a sequence of gypsum, red sandstone and siltstone, and green claystone. This sequence closely resembles the Carmel Formation of the San Rafael Swell and persists eastward into Colorado.

The eastward lithologic changes from the Twin Creek Limestone to the Carmel Formation are well shown by the sequence at Whiterocks River canyon as described below:

\section{Stratigraphic section of the Carmel Formation}

[Exposed in the canyon of Whiterocks River in NW1/4 sec. 19 and $\mathrm{SE}^{1 / 4} \mathrm{SE}^{1 / 4}$ sec. $18, \mathrm{~T} .2 \mathrm{~N}$., R. 1 E., Uintah County, Utah ]

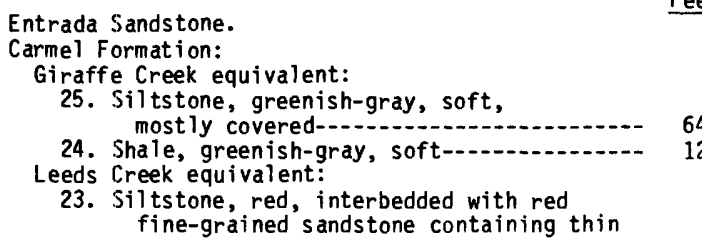

Stratigraphic section of the Carmel Formation-Continued

Carmel Formation--Con.

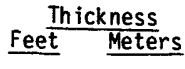

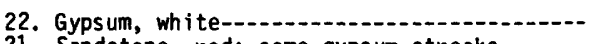

21. Sandstone, red; some gypsum streaks........

19. Shale, light-greenish-gray, finely sandy

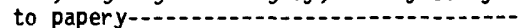

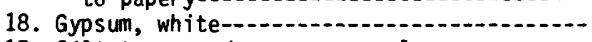

17. Siltstone, red; some green lenses-.......-

16. Shale, light-green, sandy-ale, light-green, sof $t$; some streaks of red siltstone; poorly exposed-..........

14. Siltstone, red, interbedded with gypsum---

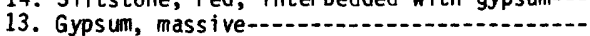

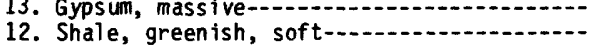

Watton Canyon equivalent:

11. Limestone, grayish-white, 1ithographic--.-

10. Limestone, 1ight-gray, shaly-...............

Boundary Ridge equivalent:

9. Limestone, light-yellowish-gray, oolitic, thin-bedded, slightly sandy, ripple marked-.......-

8. Siltstone, red, soft-_......................

Rich equivalent:

7. Claystone, greenish-gray, soft, bentonitic

6. Sandstone, white, fine-grained, soft--...-

5. Claystone, greenish-gray, very soft-...-.-.

4. Limestone, yellowish gray; thin-bedded in middle, oolitic at top and bottom; contains Pleuromya and Camptonectes--..--

3. Claystone, yellowish-gray, soft; contains thin beds of nodular yellow limestone containing oysters -..........................

2. Claystone and sandy shale, light-gray, soft; contains a 6 -inch $(15 \mathrm{~cm})$ bed of brown, sandy, oolitic limestone at base

containing Camptonectes--.--.-

1. Claystone, yellowish-green, soft

contains many very thin beds

$(0.2-0.5$ in.; $0.6-1.3 \mathrm{~cm}) 1 / 4-1 / 2$ inch of light-yeliowish-gray shaly

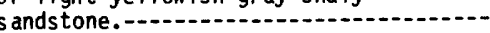

Total thick

Sharp unconformity.

Glen Canyon Sandstone (not measured).

$\begin{array}{rr}2 & .6 \\ 3 & .9 \\ 2 & .6 \\ 6 & 1.8 \\ 1 & .3 \\ 12 & 3.7 \\ 23 & 7.0 \\ 86 & 26.2 \\ 20 & 6.1 \\ 12 & 3.7 \\ 15 & 4.6 \\ 11 & 3.4 \\ 6 & 1.8\end{array}$

1.8

1.2

5.2

.6

1.8

1.2

3.7

1.5

105.2

The Sliderock Member of the Twin Creek Limestone, as exposed in the Uinta Mountains, is of particular interest stratigraphically because its lower beds are sandy, some are slightly crossbedded, and much of the member locally passes laterally into gray massive crossbedded sandstone that rests sharply on the brownish-red Glen Canyon Sandstone. Thus, in an exposure on the south side of the Duchesne River near Hanna (Imlay, $1967 \mathrm{~b}, \mathrm{p} .23)$, the member consists from bottom to top of 5 feet $(1.5 \mathrm{~m})$ of fine-grained yellow sandstone, 25 feet $(7.6 \mathrm{~m})$ of fine-grained, sandy, medium- to thin-bedded limestone, and 12 feet $(3.6 \mathrm{~m})$ of gray massive oolitic limestone. Two miles to the west on Sand Creek, in the $\mathrm{NW}^{1 / 4} \mathrm{~s}$ sec. 7, T. 1 S., R. $8 \mathrm{~W}$., the same member from its base upward consists of 4 feet $(1.2 \mathrm{~m})$ of deep-red, finegrained sandstone, 25 feet $(7.6 \mathrm{~m})$ of yellowish-gray, massive crossbedded sandstone that contains Gryphaea and Camptonectes, and then 12 feet $(3.6 \mathrm{~m})$ of gray, massive oolitic limestone. Except for this uppermost limestone, the member at Sand Creek is similar lithologically to the Page Sandstone of central and southern Utah (Fred Peterson and G. N. Pipiringos, unpub. data, 1977; 
Pipiringos and O'Sullivan, 1975) and occupies the same stratigraphic position just below limestone that contains mollusks characteristic of the Rich Member of the Twin Creek Limestone (Imlay, 1967b, p. 31, 33). These sandstone beds were first recognized by G. N. Pipiringos (oral commun., 1974) as a northern extension of the Page Sandstone.

The Preuss Sandstone in the Wasatch Mountains resembles the same formation as exposed along the Wyoming-Idaho border by consisting mostly of red finegrained sandstone, by containing saline deposits in its lower part, and by containing locally near its base a sandy limestone member (Granger, 1953, p. 11) that could be equivalent to the Wolverine Canyon Limestone Member of the Preuss of southeastern Idaho (Imlay, $1952 b$, p. 1740-1743). The exposures in the Wasatch differ from the others, however, by being softer, siltier, and darker red. This dark-red facies persists eastward into the Uinta Mountains as far as Lake Fork, but between Lake Fork and Whiterocks River canyon, it passes into light-colored, clean, crossbedded sandstone that is called the Entrada Sandstone and that extends eastward into Colorado.

Marine beds overlying the Preuss Sandstone, or the equivalent Entrada Sandstone, in the Uinta Mountains are commonly referred to the Curtis Formation (Huddle and McCann, 1947; Kinney and Rominger, 1947; Baker, 1947; Kinney, 1955, p. 85-89) or to the Stump Sandstone from Lake Fork westward and to the Curtis Formation from the Whiterocks River canyon eastward (Thomas and Krueger, 1946, p. 1278-1290). All authors cited here agree that the formation is readily divided into two distinct members. Recent studies by G. N. Pipiringos (oral commun., 1974) show that the lower member is identical lithologically and stratigraphically with the type Curtis Formation of central Utah (Gilluly and Reeside, 1928 , p. 78,79 ) and with the Pine Butte Member of the Sundance Formation in southern Wyoming (Pipiringos, 1968, p. D23). Assignment to the Curtis Formation (or Member) rather than to the Pine Butte Member is favored by the presence of basal unconformity. The Pipiringos studies also show that the upper member is identical with the Redwater Shale Member of the Sundance Formation of Wyoming and South Dakota (Imlay, 1947, p. 259-264; Pipiringos, 1968, p. D23) and is likewise characterized by an abundance of belemnites.

Recent studies by Pipiringos and Imlay (unpub. data) show also that the Redwater Member is widespread in the upper part of the Stump Sandstone, as exposed along the Wyoming-Idaho border, and that it overlies a lower member that is nearly identical with the Curtis Formation, or Curtis Member of Utah. These relationships show that the term Stump Sandstone was correctly ap- plied by Thomas and Krueger (1946, p. 1278-1290) for the western part of the Uinta Mountains at least as far east as Lake Fork north of Duchesne, Utah. Usage of the term Stump Sandstone farther east in the Uinta Mountains is justified because the Curtis and Redwater Members are fairly continuous, because of their stratigraphic relationships with each other, because the Morrison Formation is the same throughout the mountains, and because geologists to date have not found it practical to map the two members separately.

As thus defined, the Curtis Member of the Stump Sandstone in the Uinta Mountains ranges from 30 to 110 feet $(9$ to $33.5 \mathrm{~m}$ ) in thickness; consists mostly of glauconitic, fine-grained to very fine grained, thin- to thickbedded sandstone that may be even-bedded and ripple marked, or crossbedded; contains glauconite grains of the same size as the surrounding sand grains; locally contains minor amounts of green fissile or sandy shale; is characterized by furrowed trails, by round, flat shale pebble impressions, and by salt casts on bedding plane surfaces; generally rests sharply on the underlying Entrada or Preuss Sandstone; is locally marked basally by a chert pebble conglomerate; and in places contains the pelecypods Meleagrinella and Camptonectes (Thomas and Krueger, 1946, p. 1279; Kinney, 1955, p. 87-88; Untermann and Untermann, 1954, p. 51; Pipiringos, oral commun., 1975).

The overlying Redwater Member of the Stump Sandstone ranges from 115 to 140 feet (35 to $43 \mathrm{~m}$ ) in thickness; contains much soft greenish-gray shale and thin beds of glauconitic limy sandstone and sandy to oolitic limestone, which are especially common near its top and in the northern and eastern parts of the Uinta Mountains; is characterized by an abundance of belemnites and braciopods; rests sharply on the Curtis Member; and is locally marked basally by a pebble conglomerate (Thomas and Krueger, 1946, p. 1287). From Duchesne eastward, the Redwater Shale Member of the Sundance is overlain by the Windy Hill Sandstone Member of the Sundance (G. N. Pipiringos, oral commun., 1974). Elsewhere in the Uinta Mountains, the contact with the overlying Morrison Formation is generally drawn at the top of a unit of hard sandstone or oolitic limestone and is reported to be conformable but not gradational.

The Redwater Member of the Stump Sandstone in the Uinta Mountains is distinguished from the underlying Curtis Member by being generally much shalier and less glauconitic, by containing belemnites and brachiopods, by locally containing the ammonite Cardioceras, and by lacking furro red trails. Evidently the sequence near Manila, Utah, that Hansen (1965, p. 82) assigned to the Curtis Formation actually belongs entirely to the Redwater Member, although the presence near Manila 
of a few feet of the Curtis Member is reported by G. N. Pipiringos (oral commun., 1967).

All these formations and members extend eastward along the margins of the Uinta Mountains into the western part of Moffat County, in the northwestern corner of Colorado (G. N. Pipiringos, oral commun., 1974). The Carmel Formation, however, wedges out east of Miller Creek (secs. 27 and 34, T. 4 N., R. 101 W.). The Redwater Shale Member of the Sundance Formation is absent east of Uranium Peak (sec. 28, T. 2 N., R. 92 W.) in the northeastern part of Rio Blanco County, Colo. The Curtis Formation and the equivalent Pine Butte Member of the Sundance Formation are locally absent at several places within their area of outcrop, even though the underlying Entrada Sandstone and the overlying Redwater Shale Member are present.

In north-central Colorado along the margin of the Park and Gore Ranges in Eagle, Routt, and Grand Counties, the marine Jurassic is represented near Kremmling, State Bridge, and Burns by the Canyon Springs Sandstone, Lak(?), Pine Butte(?), and Windy Hill Sandstone Members of the Sundance Formation (Pipiringos and others, 1969, p. N9-N35). The lower three of these members are transitional into each other, as at Frantz Creek (fig. 27), but locally the Canyon Springs grades upward into the Pine Butte, as at Elk Creek (fig. 27). This relationship shows that the upper part of the Canyon Springs must locally be as young as the Entrada Sandstone of other areas. Its lower part, which is unfossiliferous, may or may not be as old as the typical member in Wyoming. The identification of both the Lak and the Pine Butte Members is tentative (Pipiringos and others, 1969, p. N12, N15).

Farther north along the Park Range in the Hahns Peak area of northern Routt County, the marine Sundance Formation is represented by the Canyon Springs Sandstone Member, the Pine Butte Member, the Redwater Shale Member, and the Windy Hill Sandstone Member (Pipiringos, 1972, p. 25-29). Of these, the Canyon Springs consists of about 60 feet $(18 \mathrm{~m})$ of gray to pink crossbedded sandstone and rests unconformably on Triassic rocks. The Pine Butte Member consists of about 30 feet $(9 \mathrm{~m})$ of greenish-gray shale and some thin beds of ripple-marked sandstone that intertongues downward with the Canyon Springs. The Redwater Shale Member consists of 35 feet $(10.6 \mathrm{~m})$ of glauconitic siltstone and sandstone that correlates with only the lowermost of four units of that member exposed in south-central Wyoming (Pipiringos, 1968, p. D23). The Redwater Shale Member rests unconformably on the Pine Butte Member, is truncated by the Windy Hill Sandstone Member, and is unknown south of Corral Creek (sec. 18, T. 8 N., R. 84 W.). This unconformable relationship and the wide- spread occurrence of the Windy Hill beyond the boundaries of the Redwater Shale Member demonstrates that these two members represent separate marine invasions.

The Jurassic exposed along the east side of the Front Range in northern Colorado is represented, from bottom to top, by 20 to 50 feet ( 6 to $15 \mathrm{~m}$ ) of the Entrada Sandstone, by thinner marine units belonging to the Pine Butte Member and the Windy Hill Sandstone Member of the Sundance Formation, and by the Morrison Formation (G. N. Pipiringos, oral commun., 1974). All contacts between these units are conformable except that between the Windy Hill and the Pine Butte. The conformable relationship of the Entrada Sandstone with the Pine Butte Member shows that it is equivalent at least at its top to the Lak Member of the Sundance Formation in eastern Wyoming. It is probably equivalent also to the Canyon Springs Sandstone Member in the Park Range in north-central Colorado but may be younger than the typical Canyon Springs Sandstone Member in southern Wyoming and the Black Hills.

NORTH-CENTRAL, UTAH TO SOUTHWESTERN COLORADO

The Jurassic sequence exposed in Monks Hollow (Baker, 1947; Imlay, 1967b, p. 11), about 18 miles (29 $\mathrm{km}$ ) southeast of Provo, Utah, is essentially the same as that exposed in the western part of the Uinta Mountains. A possible difference is in the 510 feet $(155 \mathrm{~m})$ of beds between the Preuss Sandstone and the Morrison Formation. The lower 260 feet $(79 \mathrm{~m})$ of these beds consists mostly of greenish-gray sandy shale interbedded with some gray to greenish-gray glauconitic sandstone and greatly resembles the unit in the Uinta Mountains that is identified with the typical Curtis Formation of central and northeastern Utah. The upper 250 feet $(76 \mathrm{~m})$ consists mostly of light-brown siltstone that contains a few beds of gray sandstone and greenish-gray shale and that was compared by Baker (1947) with the Summerville Formation. These identifications have now been confirmed by G. N. Pipiringos and the writer.

The lower 260 feet $(79 \mathrm{~m})$ of beds overlying the Preuss Sandstone at Monks Hollow occupies the same stratigraphic position as the Curtis Formation, resembles it lithologically, and likewise contains an abundance of Meleagrinella. These beds differ from the type Curtis Formation on the San Rafael Swell mainly by containing more soft clay shale and fewer hard sandstone beds and by the presence of a few cephalopods. Meleagrinella was collected throughout about 40 feet $(12 \mathrm{~m})$ of beds ranging from about 180 to 220 feet ( 55 to $67 \mathrm{~m}$ ) above the top of the Preuss Sandstone. With these were found external and internal molds of the ammonite Lytoceras (USGS 
Mesozoic loc. 30718). Also, four belemnites were obtained from the upper 10 to 15 feet (3 to $4.5 \mathrm{~m}$ ) of the Meleagrinella-bearing beds.

The next higher 250 feet $(76 \mathrm{~m})$ of beds is definitely similar lithologically to the Summerville Formation of the San Rafael Swell. Like that formation, these beds are unfossiliferous and are gradational downward into the underlying Curtis Formation. These upper beds cannot reasonably be correlated with the Redwater Shale Member of the Stump Formation, as exposed nearby in the Uinta Mountains, because that member consists mostly of greenish-gray shale, rests unconformably on the Curtis Member, and contains a fair abundance of fossils.

The presence of belemnites in the Curtis Formation at Monks Hollow is not evidence that the Redwater Shale Member is present there, because in Montana, belemnites are in beds of middle Bajocian to late Callovian Age (Imlay, 1948, p. 17; 1962b, p. C11, C21) and in the Pacific Coast region, they range throughout the Jurassic. Their presence along with Lytoceras, however, is evidence that the marine waters that deposited the Curtis Formation at Monks Hollow were deeper than those farther east in Utah and that the sea of Curtis time must have entered the western interior region from the west.

Marine Jurassic beds exposed on the west side of the Gunnison Plateau near Nephi and Levan, Utah, are defined as the Arapien Shale and are divided into two members (Spieker, 1946, p. 123-125; Hardy and Zeller, 1953, p. 1264-1266; Hardy, 1962, p. 52-54). The lower of these, the Twelvemile Canyon Member, greatly resembles the Twin Creek Limestone. It differs by being intensely folded, crinkled, and fractured and by containing more shale, more red units, and some gypsum in its upper part. Nonetheless, the lower part of the Twelvemile Canyon Member, as exposed on the south side of Red Canyon, about 2 miles $(3 \mathrm{~km})$ north of Nephi, contains units that resemble the members of the Twin Creek Limestone from the Gypsum Spring Member up to the basal part of the Leeds Creek Member (Imlay, 1964d, p. C6; 1967b, p. 30, $40,44)$. The Twelvemile Canyon Member is overlain along the Gunnison Plateau by the Twist Gulch Member, which consists of red siltstone and sandstone more than 1,800 feet $(550 \mathrm{~m})$ thick. This member is similar lithologically to the Preuss Sandstone in northern Utah, except for the presence of some gritty or pebbly beds.

Marine Jurassic beds exposed along the west side of the Wasatch Plateau near Gunnison and Salina are also referred mostly to the Arapien Shale (Hardy, 1952, p. 14-24, 67-95). The Twelvemile Canyon Member, however, is represented only by its upper part, which consists mostly of much crinkled, gypsiferous red to gray shale, siltstone, and sandstone. At its very top, it also includes $165-200$ feet $(50-61 \mathrm{~m})$ or more of red silty shale and interbedded salt (Hardy, 1952, p. 21, 22, 91). It is conformably overlain by the Twist Gulch Member, which consists of 1,670-1,730 feet $(509-527 \mathrm{~m})$ of interbedded red calcareous siltstone and claystone, reddish-gray to red sandstone, and some conglomerate. Above the Arapien Shale in the Salina Creek canyon east of Salina is 177 feet $(54 \mathrm{~m})$ of gray to green shale interbedded with and overlain by thin beds of gray sandstone. This shale contains 17 feet $(5 \mathrm{~m})$ of gray grit and some brown to red shale at its base (Hardy, 1952, p. 78). Fossils in the thin sandstone beds include Meleagrinella curta (Hall) and Ostrea.

Of these units, the upper 177 feet $(54 \mathrm{~m})$ of fossiliferous shale and sandstone is identical with the typical Curtis Formation of central Utah and is herein referred to that formation. The underlying Twist Gulch Member is similar to the Preuss Sandstone of northern Utah but differs in that it contains some pebbly beds and in that some of the sandstone beds are coarse grained or gritty, or crossbedded. The salt-bearing red silty shale, which is defined as being at the top of the Twelvemile Canyon Member, corresponds lithologically and stratigraphically with the salt-bearing red beds in the lower part of the Preuss Sandstone along the Idaho-Wyoming border (Mansfield, 1927, p. 99, 338-340; Imlay, 1952b, p. 1746). The underlying upper part of the Twelvemile Canyon Member probably correlates with the Leeds Creek and Giraffe Creek Members of the Twin Creek Limestone but differs by containing more red units, more sandstone, and more gypsum.

The described Jurassic sequences present on the west side and north end of the San Rafael Swell are typified by the sequence near Buckhorn Wash (Gilluly, 1929, p. 99-114; Gilluly and Reeside, 1928, p. 97-106, chart opposite p. 74). On the east side of the swell, they are typified by the sequences at the Black Dragon Canyon and at the San Rafael River (Baker, 1946, p. 69-90). Lithologic units within those sequences are described, correlated, and dated in various papers (Baker and others, 1936 , p. $11,25,26,31,58-63$; Imlay, 1952a, p. 961964; Wright and others, 1962; and Cater and Craig, 1970) and are summarized in figure 28 , except for the Curtis, Summerville, and Morrison Formations discussed below.

Of these three, the Curtis Formation consists mostly of greenish shale, glauconitic sandstone, and shale. Sandstone is most common and is generally thin bedded, ripple marked, and crossbedded. Shale beds are generally sandy and some are red or lavender. Conglomeratic beds occur in the lower part of the formation in the northern and northwestern parts of the swell. The contact of the Curtis Formation with the underlying Entrada Sandstone is sharp, locally angular, and is locally marked by conglomerate (Gilluly, 1929, p. 105-108; Gilluly and 
Reeside, 1928, p. 78-106; Baker, 1946, p. 80-84). The Curtis Formation contains echinoid fragments, crinoid columnals, Ostrea strigilecula White, Meleagrinella curta (Hall), Tancredia, and Camptonectes.

The Summerville Formation on the San Rafael Swell consists mainly of thin-bedded, even-bedded shale and sandstone and locally contains considerable gypsum. Generally the shales are chocolate brown to maroon, and the sandstones are reddish brown. Ripple marks are common in the sandstones. The formation grades downward into the Curtis Formation, replaces the Curtis gradationally near the Green River, and is overlain with angular unconformity by the Morrison Formation (Gilluly, 1929, p. 108-110; Gilluly and Reeside, 1928, p. 79106; Baker, 1946, p. 84-86).

The Morrison Formation in the southern part of the western interior region attains maximum thicknesses of 800-900 feet (240-270 m) (Craig and others, 1955, p. $159)$ and was derived mainly from source areas in the west-central parts of New Mexico, in Arizona, in western and northwestern Utah, and in southeastern California (Craig and others, 1955, p. 126, 150, 151, 159). Its base cannot be dated as precisely here as in areas to the north where the formation rests conformably on the Redwater Shale Member of the Sundance Formation. Presumably the Morrison Formation south of northern Utah and northern Colorado is also of late Oxfordian to early Tithonian Age.

However, the basal part of the Morrison may be of early Oxfordian Age, equivalent to the Redwater Shale Member. Such is suggested by the presence of massive gypsum at the base of the Morrison Formation in the San Rafael Swell (Gilluly, 1929, p. 114, 117; Baker, 1946, p. $87,89,90$ ). As that gypsum rests unconformably on the Summerville Formation, it cannot be as old as that formation. Instead, its presence suggests deposition in lagoons at the margin of a shallow sea, such as existed in early Oxfordian time north of the San Rafael Swell.

Recent refinements in dating the Jurassic formations in the San Rafael Swell are based on three discoveries. First, G. N. Pipiringos (oral commun., 1974) recognized that the Curtis Formation in the San Rafael Swell is identical with the Pine Butte Member of the Sundance Formation in Wyoming (Pipiringos, 1968, p. D23) and with the lower member of the so-called Curtis Formation and Stump Sandstone of northern Utah, as used by Thomas and Krueger (1946, p. 1278, 1279). All these units occupy the same stratigraphic position above the Entrada Sandstone, or equivalent units. This identification means that the Curtis Formation of the San Rafael Swell must be older than early Oxfordian, because the equivalent beds in Wyoming and in northern Utah disconformably underlie the lower Oxfordian Redwater Shale Member of the Sundance Formation and of the
Stump Sandstone. Faunally, the Curtis Formation of the San Rafael Swell is distinguished from the Redwater Shale Member by its lack of belemnites and brachiopods. These taxa are also absent in the Pine Butte Member of the Sundance Formation and in the Curtis Member of the Stump Sandstone.

Second, the lowest limestone unit in the Carmel Formation on the west side of the San Rafael Swell was dated by Imlay $(1967 b$, p. 32,33$)$ as latest Bajocian, because it contains certain pelecypods and ammonites that elsewhere are characteristic of the Rich Member of the Twin Creek Limestone and that do not range higher. In particular, the ammonite Sohlites spinosus Imlay was obtained 6-12 feet above the base of the Carmel Formation on The Wedge near Buckhorn Wash (Imlay, 1967b, p. 92, pl. 11, fig. 24).

Third, 100 feet $(30 \mathrm{~m})$ or less below the base of the Carmel Formation on the San Rafael Swell, Pipiringos and O'Sullivan (1975) recognized an unconformity that is marked by chert pebbles and that probably correlates with the unconformity at the top of the Gypsum Spring Formation in Wyoming. These pebbles are overlain by massive, crossbedded gray sandstone, which was previously assigned to the Navajo Sandstone (Gilluly, 1929, p. 98; Gilluly and Reeside, 1928, p. 72; Baker and others, 1936, pls. 13, 14; Baker, 1946, p. 68, 69) but which has now been renamed Page Sandstone (Peterson and Pipiringos, unpub. data, 1977). This sandstone has been recognized above chert pebble beds at many places in southern Utah, where it is as much as 250 feet $(76 \mathrm{~m})$ thick and where it conformably underlies and laterally intertongues with the lower part of the Carmel Formation (Pipiringos and O'Sullivan, 1975, 1978). Therefore, inasmuch as the lower part of the Carmel has been correlated with the Rich Member of the Twin Creek Limestone (Imlay, 1967b, p. 33), the underlying Page Sandstone on the swell should be equivalent to the Sliderock Member of the Twin Creek.

On the basis of these discoveries, the Curtis Formation on the San Rafael Swell is considered to be of late middle Callovian Age. The overlying Summerville Formation is considered to be only slightly younger, as shown by its gradation downward and laterally into the Curtis Formation (Baker, 1946, p. 86) and by the angular unconformity at its top. This unconformity presumably correlates in part with the regional unconformity at the base of the Redwater Shale Member of the Sundance Formation. The basal limestone of the Carmel Formation on the San Rafael Swell is dated as latest Bajocian on the basis of fossils. Consequently, the beds overlying this unit, but below the Curtis Formation, are dated as Bathonian to early or early middle Callovian on the basis of stratigraphic position. Furthermore, the lower part of the Carmel Formation, between its basal limestone beds 
and its varicolored gypsiferous beds, bears lithologic resemblances to the Boundary Ridge and Watton Canyon Members of the Twin Creek Limestone (Imlay, 1967b, p. $40,44,49$ ), which members are now dated as early to middle Bathonian.

The Jurassic formations exposed east of the San Rafael Swell, in easternmost Utah and westernmost Colorado, have been studied in considerable detail (McKnight, 1940; Dane, 1935; Baker, 1946; Wright and others, 1962; Craig and others, 1955; Cater and Craig, 1970; Shawe and others, 1968, Ekren and Houser, 1965) but are difficult to correlate and date precisely because fossils are scarce in all of them except the continental Morrison Formation. Lateral tracing of beds shows, however, that the lower, limestone-bearing part of the Carmel Formation thins eastward and pinches out a little east of the mouth of the San Rafael River (Baker, 1946, p. 71; McKnight, 1940, p. 87; Wright and others, 1962, p. 2058). The upper varicolored gypsiferous part of the Carmel Formation also thins gradually eastward, and east of the Green River in east-central Utah, it passes into reddish-brown siltstone and silty sandstone that most geologists have mapped as the eastern part of the Carmel Formation but that are now called the Dewey Bridge Member of the Entrada Sandstone (Wright and others, 1962, p. 2059). This member pinches out near the State line west of Grand Junction, Colo., but persists southeastward as a thin unit into southwestern Colorado.

East of the San Rafael Swell, the Entrada Sandstone consists of three members (fig. 28). The basal Dewey Bridge Member is conformably overlain by the Slick Rock Member, and the Moab Member is locally present at the top of the formation. The Entrada Sandstone of the San Rafael Swell extends eastward as the Slick Rock Member, a massive, crossbedded sandstone that thins to the east and southeast (Wright and others, 1962, p. 2062). The overlying Moab Member consists of massive, white, crossbedded sandstone that is at least 100 feet thick near Moab but that thins laterally away from there into ledge-forming sandstone (Baker and others, 1927, p. 804; Dane, 1935, p. 94). It is reported to intertongue laterally in places with the Summerville Formation, in places to grade downward or laterally into the Slick Rock Member, and in other places to rest on an erosion surface at the top of the Slick Rock Member (MeKnight, 1940, p. 89-97; Wright and others, 1962, p. 2063-2067; Cater and Craig, 1970, p. 30). In places where the Moab Member is absent, the Slick Rock apparently is overlain conformably by the Summerville Formation.

The Summerville Formation east of the Green Kiver in eastern Utah and in westernmost Colorado includes beds that are probably equivalent to the Curtis Forma- tion, but otherwise it maintains its lithologic characteristics, except for the presence of a few sandstone lenses. Such lenses occur (1) at its base where the Moab Member intertongues, (2) in a fairly persistent marker bed a little above its middle (Wright and others, 1962, fig. 2, 3; Shawe and others, 1968, p. A45), (3) at its top in southwestern Colorado where the Junetion Creek Sandstone intertongues (Shawe and others, 1968, p. A49, A50; Ekren and Houser, 1965, p. 12, 13; Stokes, 1944), and (4) where a similar sandstone called the Bluff Sandstone intertongues in southeastern Utah. (See summary in Craig and others, 1955, p. 132-134.)

Considerably different statements have been made concerning the nature of the boundary between the Morrison Formation and the underlying Summerville Formation, or equivalent units, as exposed along the UtahColorado border (fig. 28). Northeast of Moab, Utah, in the Salt Valley anticline area, as at Dewey Bridge, the contact is sharp, slightly irregular, and persistent (Dane, 1935 , p. 112). In the adjoining area in western Colorado, as at John Brown Valley, the contact as mapped is reported to be gradational within 15 feet or less (Cater and Craig, 1970, p. 40). Nonetheless, the absence of the Summerville Formation locally along crests of some salt anticlines could be due to erosion during early Morrison time (Cater and Craig, 1970, p. 34) or to nondeposition during Summerville time. To the southeast in the Slick Rock area, the same contact is disconformable at most places (Shawe and others, 1968, p. A58). Still farther south in the Ute Mountains area, as at MeElmo Canyon, the contact of the Morrison Formation with the Junction Creek Sandstone is locally disconformable and locally gradational (Ekren and Houser, 1965, p. 13). If these statements are correct, then deposition of the Summerville Formation was succeeded in places directly by deposition of the Morrison Formation while erosion took place in other places nearby.

\section{SOUTHWESTERN UTAH AND NORTHERN ARIZONA}

Along the Utah-Arizona border the lowermost Jurassic may be represented by units of continental origin that from the base up include the Moenave Formation, the Kayenta Formation, and the Navajo Sandstone (fig. 29). The Moenave Formation rests unconformably on the Chinle Formation, is mostly of fluvial origin, comprises three members, and drained southwestward. Of these members, the lowermost, or Dinosaur Canyon Sandstone Member, consists of reddish-orange to brown sandstone and siltstone (Harshbarger and others, 1957, p. 13; Wilson, 1965, p. 39); the middle, or Whitmore Point Member, consists mostly of gray to red siltstone and claystone but includes some limestone (Wilson, 1967); 
and the upper, or Springdale Sandstone Member, consists mostly of pale-red to brownish-red sandstone but includes some siltstone and conglomerate. The Kayenta Formation consists of light-gray to reddish-orange sandstone and siltstone that becomes finer grained and thicker southwestward, intertongues southwestward with the adjoining members, is mostly of fluvial origin (Wilson, 1965, p. 40, 42), and drained southwestward. The Navajo Sandstone consists mostly of highly crossbedded sandstone, includes some beds of cherty limestone, and is mostly of eolian origin (Harshbarger and others, 1957, p. 19-25; Wright and Dickey, 1958, p. 173; Stokes, 1963, p. 61 ; Wilson, 1965, p. 41, 42; Averitt, 1962, p. 17, 18).

The Moenave Formation occupies the same stratigraphic position as the Lukachukai Member of the Wingate Sandstone, which lies to the east and northeast and which consists mostly of eolian, large-scale crossbedded sandstone (McKee and MacLachlan, 1959, p. 22, pl. 8, figs. 5, 6, table 1; Wright and Dickey, 1958, p. 172, 173). The change from the eolian Wingate Sandstone to the fluvial Moenave Formation in southern Utah takes place within a few miles along a northwest-trending zone, which is an extension of that mapped by Harshbarger and others $(1957$, p. 3,10$)$ in the Navajo Indian Reservation in northern Arizona.

These formations are possibly of Early Jurassic age, as suggested (1) by the presence of an unconformity between the Moenave and the underlying Chinle Formation of Triassic age; (2) by an unconformity between the Navajo Sandstone and the overlying Temple Cap Sandstone of early to early middle Bajocian Age; and particularly (3) by palynomorphs dated as of late Sinemurian to early Pleinsbachian Age in the basal 15 feet $(5 \mathrm{~m})$ of the Whitmore Point Member of the Moenave Formation (Peterson and others, 1977, p. 755). Acceptance of this dating must await adequate description and illustration of the fossils and confirmation by other paleontologists. At present, the formations in question are dated by the U.S. Geological Survey as Triassic (or Triassic?) and (or) Jurassic (or Jurassic?).

This evidence suggests that the unconformity at the base of the Moenave Formation is possibly of Hettangian Age, that the unconformity at the top of the Navajo Sandstone is at least partly of late Toarcian Age, and that the Kayenta Formation and Navajo Sandstone may have been deposited during Pliensbachian and Toarcian time. Furthermore, the Navajo Sandstone may be correlated with the Dunlap Formation of western Nevada on the basis of the presence in common of nearly identical crossbedded quartz sandstone (Stanley, 1971, p. 467$475)$, on a similar stratigraphic position, and on the main source area of both formations being an uplifted northward-trending area in central Nevada. However, the sand in the Dunlap Formation may have been derived from the Navajo Sandstone by erosion. If this premise is correct, the Navajo should be at least as old as Sinemurian.

'The Temple Cap Sandstone was originally described by Gregory (1950) as a member of the Navajo Sandstone. It was subsequently made a separate formation (Fred Peterson and G. N. Pipiringos, unpub. data, 1977). It consists of two facies, or members, which extend about 75 miles $(120 \mathrm{~km})$ to the east from Gunlock, Utah, and which pinch out between the Carmel Formation and the Navajo Sandstone (fig. 29) a few miles east of Johnson Canyon. One facies, called the White Throne Member, consists of 170 feet $(52 \mathrm{~m})$ or less of pale-red to gray crossbedded sandstone that is identical with the sandstone of the underlying Navajo Sandstone but that is separated from it by 5 to 25 feet $(1.5$ to $7.6 \mathrm{~m})$ of softer red or gray siltstone and silty sandstone. The other facies, called the Sinawava Member, consists of 372 feet $(113 \mathrm{~m})$ or less of red to gray, flat-bedded sandstone, silty sandstone, mudstone, and some bedded gypsum. This facies changes eastward from red to gray at Mount Carmel Junction. To the west, the White Throne Member intertongues with the Sinawava Member near the Hurricane Cliffs on the west side of Zion National Park, and to the east it overlies a thin extension of the Sinawava Member as far east as their pinchout near Johnson Canyon, about 10 miles $(16 \mathrm{~km})$ east of Mount Carmel. The formation contains small, rounded chert granules at its base, and rests sharply on the Navajo Sandstone.

Criteria that suggest an unconformity at the base of the Temple Cap, according to Peterson and Pipiringos (unpub. data, 1977), are (1) lack of interfingering between the Temple Cap and Navajo Sandstones; (2) clear separation of these formations by a continuous surface; (3) broad irregularities at the base of the Temple Cap that are interpreted as an expression of erosional relief developed on the Navajo prior to Temple Cap deposition; and (4) a thick bleached zone at the top of the Navajo at most places, which is interpreted as alteration product of ground-water seepage into the upper part of the Navajo during a long erosion interval. These criteria and relationships show that the Temple Cap Sandstone is not a tongue of the Navajo Sandstone and should not have been considered a member of that formation by Gregory $(1950$, p. 89$)$ and later workers (Wright and Dickey, 1963a, b; Thompson and Stokes, 1971; Lewis and others, 1961).

The Carmel Formation of southwestern Utah between Gunlock and Johnson Canyon consists of four members (fig. 29) that from base to top were called the limestone member, the banded member, the gypsiferous member, and the Winsor Member by Cashion (1967). The 
same members were also described by Gregory (1950, $p$. 92-98) under the names Carmel Formation, Entrada Sandstone, Curtis Formation, and Winsor Formation, respectively. We now know, however, that rocks called the Entrada Sandstone and the Curtis Formation by Gregory are much older than those formations at their type localities in central Utah (Imlay, 1967b, p. 20, 33, $40,44)$. Of the four members, the limestone member is of most importance for age determinations because it is the only Jurassic member in southern Utah that contains datable marine fossils. Also, its lower 20-120 feet (6$36.5 \mathrm{~m}$ ) of pink to red siltstone and claystone basally contains angular chert pebbles from Zion National Park eastward, but west of the park, the same unit contains granules of rounded chert and quartz. Its lower contact, according to Fred Peterson and Pipiringos (unpub. data, 1977) is sharply defined and bevels out the Temple Cap Sandstone to the east near Johnson Canyon.

The fourfold division of the Carmel Formation persists eastward across southwestern Utah for about 90 miles $(144 \mathrm{~km})$ with little change except for thinning of the lower three members. East of the Little Bull Valley area, however, the Winsor Member grades into the middle and upper parts of the upper member of the Carmel Formation, as described by Fred Peterson and Pipiringos (unpub. data, 1977). Near the Paria River, the gypsiferous member grades into the lower part of the upper member.

Also near Little Bull Valley, 8 miles $(13 \mathrm{~km})$ southwest of Cannonville, the banded member grades into crossbedded to flat-bedded sandstone of the Thousand Pockets Tongue of the Page Sandstone (Wright and Dickey, 1963a, p. E65, E66; Phoenix, 1963, p. 32, 33; Fred Peterson and Pipiringos, unpub. data, 1977). East of the Paria River near Cannonville, the lower limestone member is termed the Judd Hollow Tongue of the Carmel Formation (Phoenix, 1963). Farther east, this tongue grades into flat-bedded sandstone and siltstone that disappears eastward between two tongues of the Page Sandstone. Evidently, the Page Sandstone, where fully developed, as at its type locality near Page, Ariz., is equivalent to both the limestone member and to the banded member of the Carmel Formation farther west.

The Page sandstone, as defined by Fred Peterson and Pipiringos (unpub. data, 1977), is as much as 291 feet $(89 \mathrm{~m})$ thick about 10 miles $(16 \mathrm{~km})$ south-southwest of Page, Ariz. It consists mostly of gray, cliff-forming, crossbedded sandstone, contains angular, red to gray chert pebbles at its base and, locally, higher, and rests sharply and unconformably on the Navajo Sandstone along a surface that locally has a relief of as much as 37 feet $(11 \mathrm{~m})$. According to Fred Peterson and Pipiringos (unpub. data, 1977) the evidence for an unconformity is strengthened by two facts: (1) the angular pebbles con- sist of the same kinds of chert that are formed in authigenic chert nodules in the Navajo Sandstone; and (2) the upper few feet of the Navajo Sandstone at many places contains crevices that they interpret as fossil joints weathered out prior to deposition of the Page Sandstone.

The Entrada Sandstone of south-central Utah, where fully developed, as at Pine Creek near Escalante, consists of three members, according to Fred Peterson and Pipiringos (unpub. data, 1977). At Pine Creek, the upper member consists of white crossbedded sandstone, the middle, of red to white to light-green flat-bedded silty sandstone and mudstone, and the lower, of red, thickbedded, flat-bedded silty sandstone. The upper member becomes truncated southward in Utah, but the middle and lower members persist considerably beyond the limits of the upper member and become sandier and more crossbedded both westward in Utah and southward in Arizona. At some places, as at Big Hollow Wash, Utah, and Page, Ariz., the middle member of the Entrada is overlain unconformably by a light-gray sandstone unit $0-44$ feet $(0-13.4 \mathrm{~m})$ thick, which has a thin red mudstone bed at its base, and which apparently occupies the same stratigraphic position as the Summerville Formation of central Utah (Fred Peterson, 1974, 1973; Fred Peterson and Barnum, 1973).

The Morrison Formation unconformably overlies the light-gray sandstone at Page and Big Hollow Wash (fig. 29). In areas where the light-gray sandstone is missing, the Morrison rests unconformably on the upper or middle member of the Entrada Sandstone. The Morrison Formation is highly variable in thickness, comprises three members of which the lower and upper may be locally absent, and is overlain unconformably by Cretaceous beds (Fred Peterson and Barnum, 1973; Fred Peterson, 1973, 1974; Zeller and Stephens, 1973).

The Jurassic formations of southern Utah are correlated with formations farther north by some lithologic resemblances, by their relative stratigraphic positions, and by the presence of certain species of mollusks in the middle to upper parts of the limestone member of the Carmel Formation. These mollusks have been found in exposures between Gunlock and the Mount Carmel-Glendale area and also in a thin limestone unit 12-20 feet (3.6$6 \mathrm{~m}$ ) above the base of the Carmel Formation at Deep Creek north of Escalante and at Hells Backbone northwest of Boulder, Utah.

At least the upper three-fourths of the limestone member of the Carmel Formation between Gunlock and Mount Carmel is dated as late Bajocian. That age is shown by the presence or association of certain species of pelecypods that in Idaho and Wyoming are characteristic of the Rich Member of the Twin Creek Limestone and are not known from higher or lower members (Imlay, 1964d, p. C3; 1967b, p. 14, 15, 31, 33). Near Gunlock, 
for example, correlation with the Rich Member is shown by the presence of Gervillia? montanaensis Meek, which occurs about 150 feet $(46 \mathrm{~m})$ above the base of the lowest limestone beds and also about 323 feet $(98 \mathrm{~m})$ higher, or 50 feet $(15 \mathrm{~m})$ below the eroded top of the member. $\mathrm{Vau}$ gonia conradi Meek, not known below the Rich Member, was found 74 miles $(12 \mathrm{~km})$ east of Gunlock in the Diamond Valley sequence $60-80$ feet $(18-24 \mathrm{~m})$ above the lowest limestone bed, and 9 miles $(14.5 \mathrm{~km})$ northwest of Hurrieane near the Danish Ranch about 60 feet $(18 \mathrm{~m})$ above the lowest limestone bed.

These fossil occurrences and others, as listed previously (Imlay, 1964d, p. C8, C9, C13; Sohl, 1965, p. D5, localities $8-12,33-38$ on p. D6, D7), show that only the lower one-fourth to one-fifth of the limestone member could be older than the Rich Member. Beds equivalent to the Sliderock Member of the Twin Creek Limestone could only be represented by the lowest 50-150 feet $(15-46 \mathrm{~m})$ of unfossiliferous limestone of the limestone member and by the underlying gypsiferous red sandy siltstone beds at the base of the Carmel Formation. Such a correlation seems most likely for the thickest sequences of the member as exposed from Gunlock eastward to Pintura and thence northeastward to Shurtz Creek about 6 miles $(10 \mathrm{~km})$ south of Cedar City. If this correlation is correct, then the unconformably underlying Temple Cap Sandstone should be of about the same age as the Gypsum Spring Formation of Wyoming and adjoining States, which is of early to early middle Bajocian Age, only a little older than the Sliderock Member.

Similarly, on the basis of stratigraphic position, the banded member of the Carmel Formation, and its equivalent Thousand Pockets Tongue of the Page Sandstone, should correlate with the Boundary Ridge Member of the Twin Creek Limestone and should be of early Bathonian Age. The overlying upper part of the Carmel Formation in southwestern Utah should correlate with the higher members of the Twin Creek Limestone and should be of middle Bathonian to early Callovian Age.

Southeastward from Page, Ariz., according to Fred Peterson (1974, p. 467; oral commun., 1974), the Page Sandstone pinches out in about 15 miles $(24 \mathrm{~km})$, the Morrison Formation, in about 30 miles $(48 \mathrm{~km})$, and the underlying gray sandstone of Romana Mesa, in about 45 miles $(72 \mathrm{~km})$. As a result, at Cow Springs, about 50 miles $(80 \mathrm{~km})$ southeast of Page, the Jurassic is represented only by the Carmel Formation and the Entrada Sandstone. Peterson noted that the Carmel Formation at Cow Springs is 188 feet $(57 \mathrm{~m})$ thick, consists of flatbedded sandstone, silty sandstone and mudstone, is mostly reddish brown, includes some angular chert pebbles at its base, and rests uneonformably on the Navajo Sandstone. At the same place, the Entrada Sandstone is 773 feet $(236 \mathrm{~m})$ thick. Its lower 197 feet $(60 \mathrm{~m})$ consists mostly of light-gray crossbedded sandstone but includes some thin beds of dark-brownish-red mudstone or sandstone. Its middle 274 feet $(84 \mathrm{~m})$ consists mostly of orange-brown to reddish-brown or white flat-bedded sandstone but includes some crossbedded sandstone. Its upper 302 feet $(92 \mathrm{~m})$ consists mostly of light-gray to greenishgray crossbedded sandstone but includes some fairly thin beds of flat-bedded sandstone and is overlain unconformably by the Dakota Sandstone. This upper unit represents the Cow Springs Sandstone of Harshbarger and others (1957, p. 49-51), but it is considered by Fred Peterson $(1974$, p. 467) to be a bleached-out upper part of the Entrada Sandstone, such as occurs in many sections in northern Arizona and southern Utah.

\section{MIDCONTINENT REGION}

The only Jurassic deposit identified to date in the middle part of the continent is in the center of the Michigan basin. It consists of 100-400 feet (30-120 m) of red clay, shale, sandstone, and some gypsum. The deposit has lenticular bedding, rests on Pennsylvanian and Mississippian rocks, contains spores identified as Kimmeridgian in age, and presumably is entirely continental (Cohee, 1965). Its age apparently coincides with that of the Morrison Formation in Montana and the Dakotas.

\section{JURASSIC UNCONFORMITIES}

A major unconformity representing more than the lower half of Jurassic time occurs throughout the northern and western parts of the Gulf region as far south as Victoria, Tamaulipas, Mexico (figs. 21, 30). This uneonformity probably continued into early Callovian time, on the basis of the probability that the overlying saline beds (Louann Salt, Werner Formation, and Minas Viejas Formation) were deposited at the same time as similar saline beds in southeastern Mexico, where conditions were unfavorable for salt deposition before late Callovian time (Imlay, 1943a, p. 1438, 1508-1510; 1953c, p. 31; Viniegra $0 ., 1971$, p. 480,484$)$.

Farther south, in the Huasteca area of eastern Mexico, an unconformity of such magnitude is not recognizable except locally on certain uplifts. Instead, the same time interval is represented by (1) an unconformity of Hettangian Age, (2) marine and plant-bearing deposits of Sinemurian and questionably of early Pliensbachian Age, (3) an unconformity of Pliensbachian to Toarcian Age caused by orogenic activity, (4) continental beds of Bajocian to Bathonian Age, (5) an unconformity of latest Bathonian and earliest Callovian Age, and (6) marine beds of late early Callovian and younger ages. Bajocian 


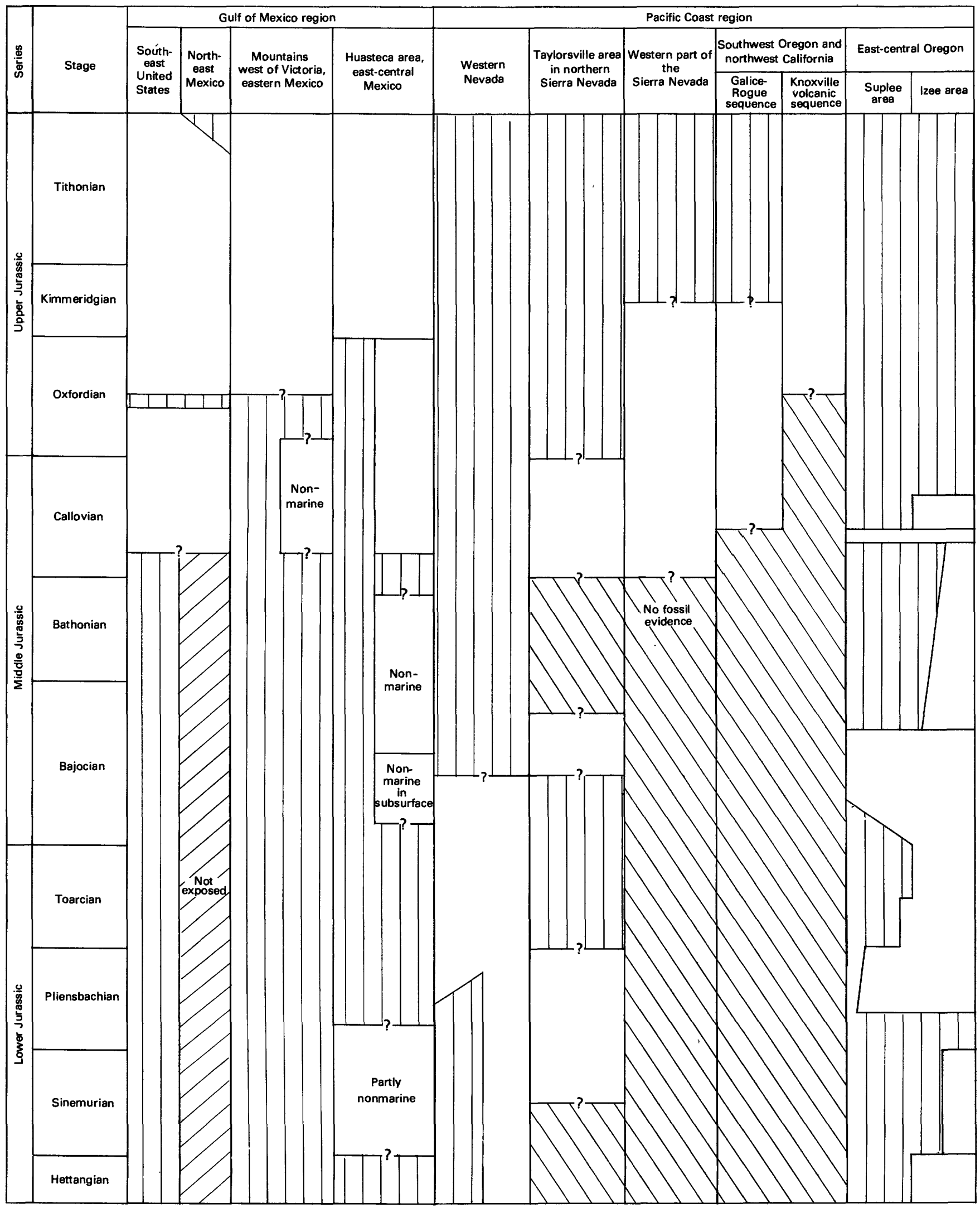

FIGURE 30.-Jurassic unconformities in Gulf of Mexico and Pacific Coast regions. Blank spaces indicate that marine strata are present; vertical lines indicate that strata are missing; left-diagonal lines indicate that strata are not exposed; right-diagonal lines indicate lack of fossil data. 


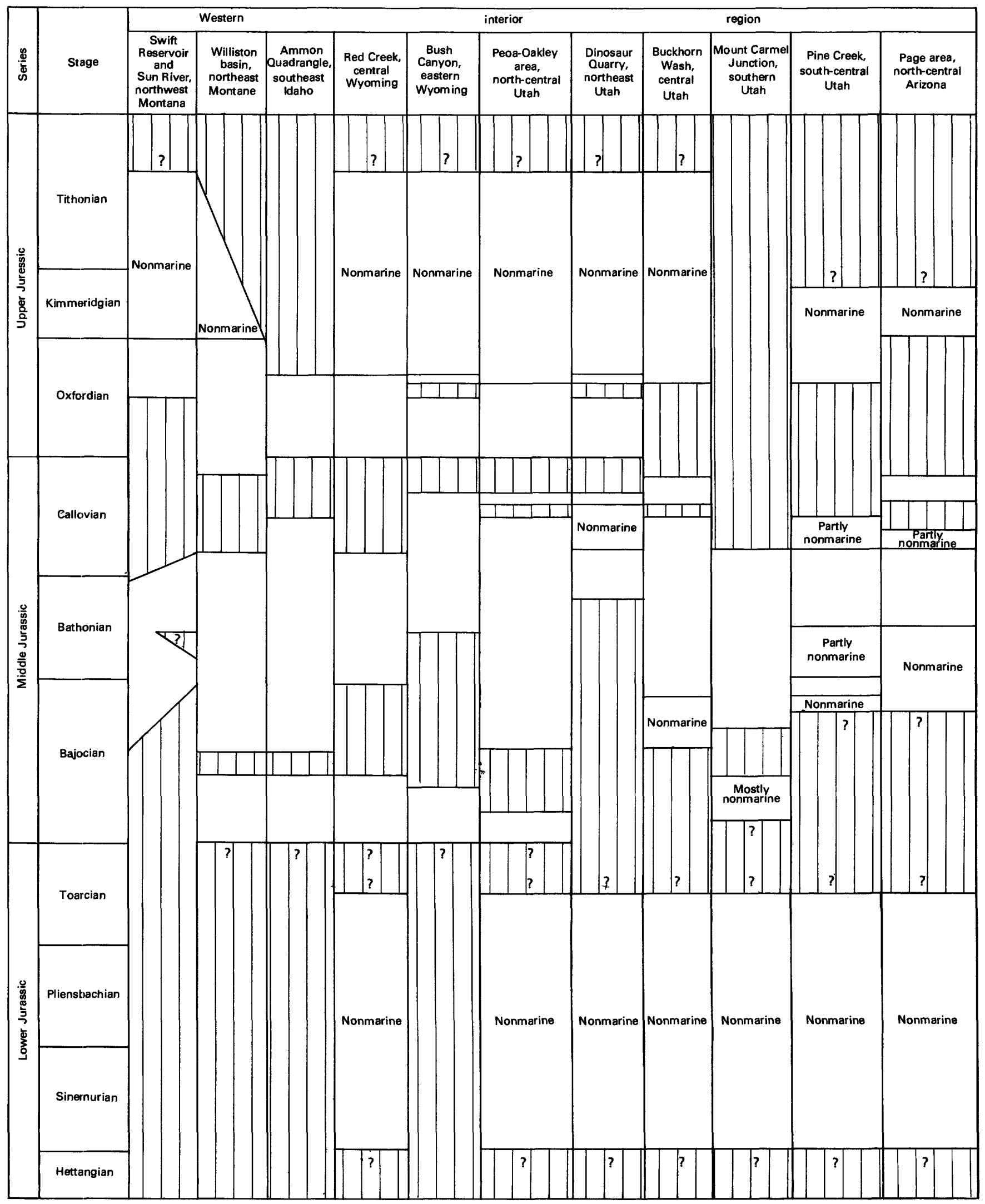

FIGURE 31.-Jurassic unconformities in western interior region. Blank spaces indicate that marine strata are present; vertical lines indicate that strata are missing. 
and Bathonian continental beds in the Huasteca area correlate fairly well in time with similar plant-bearing beds in the States of Guerrero and Oaxaca in southern Mexico and with the plant-bearing San Cayetano Formation in Cuba. The fact that beds of Kimmeridgian Age locally rest on beds of Sinemurian to possible earliest Pliensbachian Age suggests that certain areas were islands from Middle Pliensbachian to late Oxfordian time, or that erosion occurred in late Oxfordian time, or that both things may have happened.

The orogenic activity associated with the unconformity of Pliensbachian to Toarcian Age (Imlay, Cepeda and others, 1948, p. 1750-1753; Carrillo Bravo, 1965, p. 85, 87, 92-95) suggests that the unconformity developed mainly during Pliensbachian time and may be areally more extensive in the Gulf region than is now realized. Also, it may correlate roughly with an unconformity of early Pliensbachian Age in eastern Oregon, southwestern Alberta, arctic Canada, and Alaska (see fig. 13); with uplift of an area in eastern Nevada from which the sands of the Dunlap Formation were derived (Muller and Ferguson, 1939 , p. 1616-1622); and with intrusion of diabase sills (Palisade disturbance) into continental beds of Sinemurian Age in New Jersey (Dallmeyer, 1975).

In addition, several minor unconformities of Late Jurassic age have been recognized in the northern and western parts of the Gulf region. These include (1) a probable minor disconformity of middle Oxfordian Age formed after deposition of the main saline beds (Louann Salt) by a swiftly transgressing sea (Norphlet Formation) which reworked the surface of the saline beds and transgressed beyond; (2) a minor disconformity of early Kimmeridgian Age formed locally in Mexico and possibly also in the southeastern United States, at the same stratigraphic position as a nearby gypsiferous red-bed unit (Olvido Formation and Buckner Formation); and (3) a disconformity formed locally at the top of the Jurassic in the Gulf region of the United States.

In the Pacific Coast region, the entire Jurassic is represented by unconformities at one place or another (fig. 30 ). Of those unconformities found in two or more places, some represent Hettangian, early Pliensbachian, Bathonian, early Callovian, and late Callovian time. Others begin in middle Bajocian, middle Callovian, and late Kimmeridgian time and continue through the remainder of the Jurassic. These unconformities lack continuity over large distances, owing to westward shifting of depositional troughs during Jurassic time, to deposition in waters ranging from very shallow to very deep, to distances from sources of sediment, and to the presence of islands rising from waters of different depths. Thus, the unconformable relationships noted in the Suplee-Izee area of eastern Oregon (fig. 30 ) were produced by westward onlap of a sea across an island composed of Paleo- zoic and Triassic rocks and by periodic uplift of that island in early Pliensbachian time and later, perhaps accompanied by variations in sea level.

Six unconformities have been definitely identified in the Jurassic sequences of the western interior region (fig. 31) (Pipiringos, 1968, p. D10, D11). These, from oldest to youngest, represent (1) the later part of the Early Jurassic, (2) the middle part of the middle Bajocian, (3) a small part of the middle Callovian locally in Utah, (4) most of the late Callovian and locally some of the Oxfordian, (5) a small part of late early or early middle Oxfordian locally in the middle part of the region, and (6) at least part of the later Tithonian. Complete withdrawal of marine waters took place during the development of the first, second, fourth, and sixth unconformities listed. The lowest unconformity formed during the late Early Jurassic, as shown by its position below marine beds of early Bajocian Age and above the continental Navajo Sandstone, which is now dated as probably Early Jurassic (Fred Peterson, written commun., 1976) on the basis of the palynoflora present in the older Moenave Formation. The highest unconformity formed during the latest Jurassic, and it could represent all or only part of the Tithonian. Because it formed on continental beds, it probably represents more time than the unconformity at the top of some marine Jurassic sequences in the southeastern United States and in west Texas. It represents considerably less time than the unconformity (Nevadan orogeny) formed after deposition of the Mariposa and Galice Formations in parts of California and Oregon.

All these Jurassic unconformities in the western interior region could result from lowering of sea level by a few hundred feet or less, or from a slight elevation of the region, or from a rise of landmasses in eastern Nevada, western Utah, and central Idaho that blocked the entrance of marine waters from the west. Of these unconformities, only that of late Callovian Age can be matched definitely in the Pacific Coast region. In addition, the unconformity of middle Bajocian Age, corresponding roughly to the European zone Otoites sauzei, may be present locally in British Columbia and southwestern Alberta, as suggested by the rarity of ammonites characteristic of that zone (Imlay, 1973, p. 34).

\section{JURASSIC GEOLOGIC HISTORY}

\section{ATLANTIC COAST REGION}

Deposition of marine Jurassic sediments along the Atlantic Continental Shelf of the United States has not been demonstrated by fossils. Nonetheless, seismic evidence suggests that fairly thick Jurassic sequences were 
deposited at least on the outer part of the shelf. This cont clusion is supported by the presence of (1) about 6,500 feet $(1,980 \mathrm{~m})$ of Lower to Upper Jurassic beds in the Scotia Shelf area and at least 20,000 feet $(6,100 \mathrm{~m})$ of such beds in the Grand Banks of Newfoundland, (2) $8,000-16,000$ feet $(2,440$ to $4,880 \mathrm{~m})$ of Middle to Upper Jurassic beds in Cuba, and (3) a thin Upper Jurassic sequence in the Hatteras Abyssal Plain. As the last mentioned sequence contains organisms characteristic of fairly deep waters (Luterbacher, 1972, p. 575; Bernoulli, 1972, p. 813; Bernoulli and Jenkyns, 1974, p. 145, 146), the Jurassic sea probably extended considerably farther west. Also, the marked lithologic and stratigraphic differences among these sequences suggest that the history of Jurassic sedimentation probably differed considerably from place to place. All available evidence indicates that the North Atlantic formed near the end of the Triassic, was much smaller during the Jurassic than today, was the site of salt deposition at one or more times, and was flooded extensively by marine water of normal salinity from Oxfordian to Tithonian time, coincident with extensive flooding in the Gulf of Mexico region (Gordon, 1974, p. 138; Berggren and Hollister, 1974, p. 130, 131, 176).

\section{GULF OF MEXICO AND NEARBY REGIONS}

Jurassic marine sedimentation in or near the Gulf region began at different times in different places. Marine sedimentation in Cuba probably began during the Bathonian, but possibly as early as Bajocian. In the southern United States and northeastern Mexico, deposition probably began during the Callovian, but possibly a little earlier. Sedimentation started in north-central Mexico during the middle Oxfordian, in northern Chihuahua and western Texas during the Kimmeridgian, and in the Huasteca area of east-central Mexico during the Sinemurian. In eastern Veracruz in east-central Mexico, marine deposition probably began as early as late Bathonian and definitely as early as Callovian. In south-central Mexico in the State of Guerrero, deposition definitely began as early as Pliensbachian and probably much earlier.

During Early Jurassic time, marine sedimentation probably did not take place within the drainage basin of the Gulf of Mexico. Field studies in southern Mexico and drilling in the region of Veracruz both show that an Early Jurassic sea entered southern Mexico from the Pacific Ocean and extended north or northeast but did not quite reach the area of the present Gulf of Mexico. Consequently, marine Sinemurian and questionable lower Pliensbachian beds exposed in the Huasteca area pinch out eastward in the subsurface against ancient schist, gneiss, and granite in eastern Veracruz (Viniegra 0 ., 1971, p. 484; Lopez Ramos, 1972, sections $A-A^{\prime}$ and $B-B^{\prime} ; 1974$, p. 381-386). Earlier studies favoring a marine connection eastward with the Atlantic Ocean during Early Jurassic time were based on the close similarities between the Sinemurian ammonite faunules in southern Mexico and those in Europe (Burckhardt, 1930, p. 20; Erben, 1957b, p. 37, 38). It is now known, however, that the Early Jurassic ammonite succession is remarkably similar throughout the world from Hettangian to early Pliensbachian time (Imlay, 1971, p. 712-713; Imlay and Detterman, 1973, p. 21) and is fairly similar until Bajocian time.

Likewise, continental sedimentation may not have taken place within the Gulf of Mexico drainage area during Early Jurassic time. The best evidence for its occurrence consists of plant-bearing black shale within and directly overlying Sinemurian marine beds in the Huasteca area of east-central Mexico (Burckhardt, 1930, p. 20; Erben, 1956a, p. 129-132; 1957a, p. 45). That area, however, may have drained southward or southwestward rather than eastward, because the associated marine beds were deposited in an arm of the Pacific Ocean. If that is true, then at least the western part of the Gulf of Mexico may not have existed during Sinemurian and early Pliensbachian time. Such a possibility is supported by the fact that the Jurassic beds in the Huasteca area were folded, faulted, intruded by igneous rocks, metamorphosed, and then partially eroded away before deposition of the overlying continental Cahuasas Formation of Bajocian to Bathonian Age (Carrillo Bravo, 1965, p. 85-87, 92-95).

During Bajocian time, and most or all of Bathonian time, marine sediments were not deposited within the drainage basin of the Gulf of Mexico, as far as is known. Well outside that basin, however, those stages are represented in part in western Oaxaca and northeastern Guerrero by marine beds deposited in an embayment of the Pacific Ocean (see fig. 6, 7, 14, and 21). Within the Gulf drainage basin, the latest Bathonian is possibly represented by some small undescribed ammonites resembling Wagnericeras, which were obtained from the subsurface near Tampico in east-central Mexico (Cantú Chapa, 1969, p. 5). Also, in western Cuba, the upper 2,000 feet $(610 \mathrm{~m})$ of the enormously thick San Cayetano Formation has furnished a few marine pelecypods that could be of Bathonian Age, providing the overlying Azucar Member contains Callovian microfossils as reported (Meyerhoff, 1964, p. 151).

During Bajocian and Bathonian time, continental sediments were deposited widely in the Gulf region and in nearby areas. In the Tampico and Huasteca areas of eastcentral Mexico, some thick red to gray clastic non-marine beds, called the Cahuasas Formation, were laid down from middle Bajocian to at least middle Bathonian time on top of plant-bearing beds of early Bajocian Age (Carrillo Bravo, 1965, p. 87-88; Erben, 1956a, p. 137; 
1956b, p. 43). In Cuba, those stages are probably represented by thousands of feet of plant-bearing beds in the San Cayetano Formation.

Outside the Gulf region, in northeastern Guerrero and western Oaxaca, some dark-gray to black carbonaceous plant-bearing shale and coaly beds were deposited during Toarcian to early middle Bajocian time and again during middle Bathonian time (Erben, 1957a, p. 49-50), as dated by marine fossils in adjoining beds. Studies of the plant fossils have made it possible to assign an early Bajocian date to the basal part of the Cahuasas Formation of east-central Mexico, as mentioned above. The presence of plant fossils and carbonaceous material in both east-central and southern Mexico suggests that the climate was generally warm and humid throughout the Gulf region during most of the Early and Middle Jurassic.

During Callovian time, marine sediments probably were deposited in Cuba (Meyerhoff, 1964, p. 151; Meyerhoff and Hatten, 1974, p. 1211), but the evidence has not yet been published. Marine sediments of early to middle Callovian Age were definitely deposited in eastcentral Mexico near the present Gulf of Mexico and may represent an embayment of the Gulf (Erben, 1957b, fig. 2). Recent studies, however, strongly favor the theory that deposition took place in an embayment that extended northeastward from the Pacific Ocean and that was separated from the Gulf at least in part by a land barrier (Viniegra O., 1971, p. 484, 492; Lopez Ramos, 1974 , p. 388 ).

Thick masses of salt and associated anhydrite probably were deposited during middle or late Callovian to early Oxfordian time in various parts of the Gulf region. Such an age is suggested by (1) the stratigraphic position of the salt and anhydrite below normal marine beds of middle Oxfordian to early Kimmeridgian Age, (2) lack of evidence of any appreciable erosion before the overlying normal marine beds were laid down, and (3) lack of any fossils that are definitely of late Callovian to early Oxfordian Age either above or below the saline deposits. In particular, the Santiago Formation of east-central Mexico contains early to middle Callovian ammonites in its lower part, late Oxfordian ammonites in its upper part, but apparently no fossils of any kind in its middle part.

Considering the distribution and stratigraphic positions of the main saline masses in the Gulf region, some marine waters from both the Atlantic and Pacific Oceans probably entered the Gulf at about the same time. The entrance of seawater into the Gulf during salt deposition probably resulted from some structural movement that either caused a rise in sea level, or a downwarping of landmasses in southern Mexico and between Cuba and
Florida. The fact that the Callovian sea in east-central Mexico was bounded on the east by a barrier or uplift suggests that most of the marine water that furnished the salt came from the east.

Some red to varicolored continental beds, called La Joya Formation, were probably deposited during Callovian time in northeastern and north-central Mexico. These beds differ from the Cahuasas Formation by containing some red-weathering lava, by being much thinner and redder, and by not passing downward into plant-bearing beds. They could be the same age as that formation, but their close geographic proximity in northeastern Mexico to thick salt and gypsum masses, called the Minas Viejas Formation, suggests that they were formed at the same time as the saline beds. Presumably, the red sand and silt in the red beds were derived from areas to the west or north, where red lateritic soil accumulated under a hot and seasonably rainy climate. The salt and the red beds probably were deposited under a hot and very dry climate.

The sequence of marine sediments deposited during Late Jurassic time were remarkably similar from Alabama westward to north-central Mexico. During the late middle to late Oxfordian in offshore areas, the deposits were mostly limy mud; in nearshore areas, they were limy mud or sand or both, and locally in nearshore areas they were limy sand and gravel. The upper part of the limy mud sequence was deposited in shallow agitated water, and the lower part, apparently in deeper and rather quiet water.

Seas having unrestricted circulation and normal salinity suddenly became widespread in the Gulf region near the middle of the Oxfordian and gradually expanded until near the end of the Jurassic. At the beginning of that time interval, the portals from the Atlantic Ocean, or the Pacific Ocean, or both, suddenly widened and deepened, allowing huge quantities of sea water to flood abruptly inland over older Jurassic saline and continental beds onto Triassic red beds and Paleozoic rocks. The extent of the late Oxfordian sea (fig. 10), far beyond the present Gulf of Mexico, suggests that either the older evaporite basins within the Gulf were dead seas considerably lower than ocean levels, or that the entire Gulf basin sank fairly rapidly during the Oxfordian, or that both conditions existed. The first possibility is favored because the sea spread quickly over an area extending at least 1,500 miles $(2,400 \mathrm{~km})$ from east to west, because it reworked the saline beds only slightly as it advanced and because it then quickly covered those beds with a protective blanket of red to gray mud and sand (Norphlet Formation) that prevented further erosion. Nonetheless, the fact that considerable sand and pebbles were shed into the sea from the north during most of Late Jurassic 
time shows that land areas to the north were rising as the Gulf basin itself was sinking. The fact that the saline deposits of the Gulf region extended at least as far east as Cuba and probably considerably farther east suggests that major tectonic movements allowed normal marine waters from the major oceans to flood smaller basins such as the Jurassic Atlantic basin and the Gulf of Mexico.

In the Gulf region of the southeastern United States, the initial deposits of the rapidly advancing middle Oxfordian sea were derived mostly from pre-Jurassic rocks and from Jurassic saline beds across which the sea transgressed. These deposits (Norphlet Formation) were succeeded rather abruptly in offshore areas by dense, finely laminated, silty to shaly, calcareous muds (lower part of the Smackover Formation) that contain well-preserved specimens of the fragile-shelled pelecypod Bositra (not Posidonia). Such muds must have been deposited in quiet, toxic waters, as indicated by the fine laminations and by the good preservation of the fragile pelecypod shells. However, these waters were not necessarily deeper than the lower part of the neritic zone. Also, rapid deepening of the sea at the beginning of Smackover time is indicated by the abrupt change from deposition of red mud, sand, and some pebbly beds to the deposition of laminated beds.

In offshore areas in the southern United States, these laminated limy beds in the lower part of the Smackover Formation were overlain by gray to black mud of the Bossier Formation in late Oxfordian to late Kimmeridgian time. In some nearshore areas, though, the laminated beds were succeeded by limy dense to oolitic mud and sand representing the middle and upper parts of the Smackover, which was in turn overlain by the Buckner Formation in early Kimmeridgian time. The Buckner consists of red to greenish-gray mudstone, anhydrite, dolomite, oolitic carbonate, and, locally, salt, which were deposited as a rather narrow lens-shaped body now extending from east Texas through Arkansas to Alabama.

Deposition of the Buckner and Smackover Formations was succeeded conformably in most nearshore (updip) areas by deposition of red to gray fine-grained sand and mud (Schuler Formation), which may have been deposited in brackish or nonmarine waters. However, the local thinning or absence of the Buckner Formation over the crests of some salt anticlines may indicate a local disconformity at the base of the Schuler Formation (Weeks and Alexander, 1942, p. 1475; K. A. Dickinson, 1968, p. $\mathrm{E} 13, \mathrm{E23}$ ). The Bossier Formation is overlain by marine shale and gray sandstone (marine facies of the Schuler Formation) that become more shaly basinward, suggesting deeper waters offshore. Deposition apparently con- tinued to the end of Jurassic time offshore but not in nearshore areas.

In summation, the Smackover Formation was deposited in a transgressive sea that was very shallow and agitated nearshore and apparently deeper than wave base offshore. The Buckner Formation was deposited in evaporitic basins partially blocked off from the sea by salt anticlines or by local uplifts. The Bossier Formation was deposited in moderately shallow waters in offshore areas. The Schuler Formation was deposited in shallow water that was brackish in part, or perhaps nonmarine in nearshore areas. It has been interpreted as a mostly regressive deposit. Nonetheless, the fact that it extends north of the Smackover and Buckner Formations in Arkansas (K. A. Dickinson, 1968, p. E10, E14, E23) shows that its lower part, at least, is transgressive with respect to those formations.

In north-central and northeastern Mexico, deposits of limy mud or sand of late middle to late Oxfordian Age were overlain by dark limy mud or clay (La Caja Formation), or by gray to black sand, limy mud, gravel, and some coaly beds (La Casita Formation), or by gypsiferous red beds and gypsum (Olvido Formation). These gypsiferous beds crop out only in the high mountains of eastern Mexico from Victoria, Tamaulipas, northward to eastern Coahuila. They are of particular interest because they were deposited at the same time as the Buckner Formation of the southern United States, they are nearly identical lithologically, and they also were deposited as a narrow lens-shaped body. They must represent a time of uplift and slight folding, because in areas where they are absent, the Oxfordian beds are generally overlain disconformably by La Casita Formation or by La Caja Formation, which were laid down during the remainder of the Jurassic.

Of these lithologic units, the Olvido and La Caja Formations were probably deposited under conditions similar, respectively, to those of the Buckner and Bossier Formations in the southern United States. La Casita Formation was deposited in shallow water or under nonmarine conditions, as was the Schuler Formation. Nonetheless, the dark-gray to black color of the La Casita and the presence of coal beds and considerable carbonaceous material within it contrast with the red to gray colors of the Schuler Formation and show that the climate on nearby landmasses must have been much more humid during deposition of La Casita Formation. Also, the fact that La Casita Formation in Chihuahua and equivalent beds in west Texas lap considerably beyond older Jurassic beds onto Permian rocks shows that the formation is distinctly transgressive.

Farther south, in the Tampico and Huasteca areas of east-central Mexico (fig. 21), the lithologic units of 
Oxfordian to Tithonian Age differ considerably from those of the same age in northern Mexico. They consist almost entirely of dark-gray to black normal marine shale and shaly to thin-bedded limestone. Sandy beds and pebbles are uncommon, and the highest unit (Pimienta Formation) contains thin lenses of chert. Evidently these beds were deposited as soft limy mud in an open, shallow or fairly shallow sea that received very little sandy material. Locally within this sea, on platform areas or nearshore, were deposited bioclastic, oolitic, and coralline reef carbonates (San Andrés Member of Taman Formation) (Cantú Chapa, 1969, p. 8; 1971, p. 3436).

Still farther south, drill cores from near Chinameca and Cerro Pelon, Veracruz, in the Chiapas salt basin, show that deposition of considerable salt and some associated red to black mud was followed by deposition of a thin unit of red mud and some salt. That in turn was followed by deposition of normal marine beds of early Kimmeridgian to early Neocomian Age. Elsewhere in southeast Mexico, the Upper Jurassic deposits outside the salt basin apparently were mostly red mud. On the Chiapas massif, however, the deposition of red mud was interrupted briefly by a marine incursion during early Kimmeridgian time. The deposition of red beds and salt masses implies arid conditions during Late Jurassic time, which was a marked climatic change from Early and Middle Jurassic time when considerable coal and carbonaceous material was deposited in nearby parts of southern Mexico. Furthermore, the characteristics of the marine beds of Kimmeridgian and Tithonian Age in the Chiapas basin indicate that water depth was generally shallow and that bordering land areas were very low (Viniegra 0., 1971, p. 485-487).

\section{PACIFIC COAST REgION}

The Jurassic marine sequences deposited in the Pacific Coast region of the United States differ markedly lithologically within fairly short distances, attain enormous thicknesses, and contain a great deal of volcanic material. In addition, some represent different ages from others that are nearby. These differences are attributable to deposition under changing environmental conditions; to the relative positions of the sequences within rapidly sinking basins; to differing distances from volcanic vents, from islands, or from landmasses composed of pre-Jurassic rocks; to westward shifting of depositional sites during Jurassic time; and to major post-Jurassic thrust faulting that has brought together sequences that were originally deposited far apart under very different environmental conditions. Evidently, the changing environmental conditions reflect the gradual westward shift in depositional sites, which in turn reflects major orogenic movements along the western margin of the continent.

During the Early Jurassic, a shallow to very shallow sea existed as far east as the Snake River in eastern Oregon and nearly as far east in Nevada. Fossil mollusks from this sea have been found as far west as the SupleeIzee area in east-central Oregon, the Big Bend area in north-central California, and the Sailor Canyon area a little west of the crest of the Sierra Nevada on the North Fork of the American River in eastern California. The sea in Nevada and eastern Oregon continued from latest Triassic time and during Hettangian to Sinemurian times received sediment similar to that deposited during the Triassic. In contrast, the lowermost Jurassic sediments deposited in the Sailor Canyon and Big Bend areas are of Sinemurian Age and were deposited unconformably on Triassic rocks or locally in Sailor Canyon on older rocks. These relationships suggest that the center of the Early Jurassic seaway was in western Nevada rather than in eastern California and probably trended northward through eastern Oregon. The fact that no Lower Jurassic beds are known in western California and western Oregon does not mean necessarily that an Early Jurassic sea did not also exist there. The absence of these beds, as well as the absence of Bajocian and Bathonian beds in those areas, could be a consequence of major tectonic events during Bathonian to early Kimmeridgian time that resulted in the formation of oceanic crust and that either altered or destroyed preexisting sediments.

During Bajocian time, the sea covered nearly the same area as it did during earlier Jurassic time, and as before, it had marine connections both northward into Canada and southward into Mexico. In addition, during the later Bajocian, this sea had marine connections eastward through Idaho into the western interior region. The marine sediments deposited near Westgate, Nev., consisted of limy mud and quartz sand; those deposited in the Santa Ana Mountains of southern California consisted of mud, sand, gravel and some limestone lenses; those deposited in the northern Sierra Nevada near Taylorsville consisted of volcaniclastic materials and some limy lenses; those deposited in the big Bend area of north-central California consisted of volcaniclastic materials, lava flows, and some clastic lime muds; and those deposited in eastern Oregon consisted of volcaniclastic materials, some silty to sandy lime mud, and much dark clay and silt associated with much fine volcanic material. Most of these sediments, as shown by their fossil content and lithologic features, were deposited in normal shallow marine waters that were much agitated in some places and were quiet in others. The shallowness of the sea in the Taylorsville area during Bajocian time is at- 
tested to by the faunal content of the Mormon Sandstone (Crickmay, 1933b, p. 898, 899) and by the presence of a disconformity below the Mormon.

Marine beds of Bathonian Age have not been found in the Pacific Coast region south of eastern Oregon, but neither has any physical evidence been found for an unconformity of that age. In the Taylorsville area in eastern California, the Bathonian could be represented by about 1,300 feet $(396 \mathrm{~m})$ of volcanic breccia and tuff between the Moonshine Conglomerate of early late Bajocian Age and the Hinchman Sandstone of early Callovian Age. In the Izee area of eastern Oregon, the Bathonian is represented within a mudstone-siltstone unit 1,250 2,000 feet $(381-610 \mathrm{~m})$ thick that is called the upper member of the Snowshoe Formation. In that member, early Callovian ammonites have been collected from its highest 300-500 feet (91-152 m), Bathonian ammonites, from its next lower $300-400$ feet (91-122 m), and one late Bajocian ammonite (Leptosphinctes), from near its base. That leaves hundreds of feet of beds that could also represent the Bathonian and uppermost Bajocian. As marine Bathonian beds containing ammonites of boreal affinities occur in central British 'Columbia, southern Alberta, and western Montana, a Bathonian seaway probably extended from British Columbia southward and southeastward across parts of Washington and Idaho.

During Callovian time, a sea apparently covered most of California, all of Oregon, part of western Idaho, and probably most of Washington. During early Callovian time, it also extended eastward through southern Alberta and probably also through northern Idaho into the western interior region of the United iStates and Canada. That sea, so far as is known, did not extend into Nevada as did the Bajocian sea but did extend into northeastern Oregon where Bajocian beds are unknown.

Sediments deposited in this Callovian sea in the Pacific Coast region are very thick and contain a great deal of volcanic ejecta such as agglomerate, breccia, lava flows, and ash (see figs. 22, 23). Even the finer sediments deposited as sand, silt, and clay contain much fine volcanic material. Deposition was nearly continuous from early to middle Callovian time in eastern Oregon and apparently continued through the entire Callovian into early Oxfordian time in parts of California and southwest Oregon. One exception cocurs, however, in the Izee area of eastern Oregon, where an unconformity has been found near the middle of beds of early Callovian Age (W. R. Dickinson and Vigrass, 1965, p. 84). The presence of an unconformity at that position is supported by the much wider distribution of the beds above than below that position. Thus, the Trowbridge Shale overlaps westward onto beds of middle Bajocian Age (Imlay, 1978, p. $9,14)$.
Early Callovian sediments in the Izee-Suplee area of eastern Oregon were deposited on beds of late Bajocian to Bathonian Age. In the Taylorsville area of northeastern California, they were deposited on beds of probable Bathonian Age. Elsewhere in California and in western Oregon, the age of the beds underlying Callovian sediments is not known, either because of lack of fossils or because of thrust faulting. As the age of the Rogue Formation in southwestern Oregon is based on its stratigraphic position gradationally beneath beds of late $\mathrm{Ox}$ fordian Age, its lower part could be as old as Bathonian. Similarly, the lower part of the Logtown Ridge Formation, or the equivalent Gopher Ridge Volcanics, as exposed along the foothills of the Sierra Nevada, could locally be of Bathonian Age.

The Callovian sediments in California and Oregon were deposited in rapidly sinking basins, which were receiving quantities of lava and coarse volcanic material from vents and volcanoes. Some of the Rogue Formation may represent newly formed oceanic crust, as indicated by the presence of lava flows, agglomerates, breccias, tuff, serpentine, and gabbro intrusive rocks. The Logtown Ridge Formation or the Gopher Ridge Volcanics could also locally represent oceanic crust, although a somewhat different environment of deposition is indicated by the presence of ammonites at various levels.

During the Oxfordian to early Kimmeridgian, a sea covered much of California west of the crest of the Sierra Nevada, extended northwestward into Oregon, covered at least the northwestern part of Washington, and received much volcanic sediment. Another sea of early Oxfordian Age extended southward from easternmost Washington a short distance into Idaho and Oregon near the present site of the Snake River and received nonvolcanic mudstone, graywacke, and pebbles. Except for the area near the Snake River, highly volcanic marine sedimentation continued from the Callovian into the early Oxfordian. By contrast, the marine sediments deposited from late Oxfordian to early Kimmeridgian time wére mostly dark clay but included some silt, sand, and gravel and only in places included appreciable volcanic material. Apparently near the middle of Oxfordian time, volcanism either decreased markedly or shifted far to the west of its position during Callovian or earlier $\mathbf{O x}$ fordian time. Such a shift is indicated by the presence near Paskenta, Calif., of thousands of feet of mafic volcanic rocks (mostly breccias and flows) (Bailey and others, 1970, p. C72-C74) conformably below the Knoxville Formation, the base of whieh is dated as late Kimmeridgian at that place (Jones, 1975).

At the end of the early Kimmeridgian, marine sedimentation ceased for the remainder of the Jurassic in areas underlain by the Galice and Mariposa Formations, 
as well as in areas a little farther east. Such areas during the remainder of the Jurassic were subjected to uplift, folding, igneous intrusion, and much erosion associated with the Nevadan orogeny. Orogenic activity ceased, however, by the end of the Jurassic in western Oregon, where the Galice Formation locally was overlain by marine sediments of earliest Cretaceous age.

During the late Kimmeridgian, marine sediments were deposited in areas of northwestern Washington and northwestern California. During the Tithonian, deposition took place along a narrow belt whose position is now shown by fossiliferous beds near the present coast from Baja California to northwest Washington. All this deposition took place at least 100 miles $(160 \mathrm{~km})$ west of areas in which the Mariposa and Galice Formations were deposited during the late Oxfordian to the early Kimmeridgian. Evidently, the deposition of sediments of early Kimmeridgian Age coincided with the beginning of the Nevadan orogeny in areas underlain by the Mariposa and Galice Formations and in the Sierra Nevada.

Marine sedimentation during late Kimmeridgian to late Tithonian time varied considerably from place to place, apparently depending on the depth of the sea, the distance from shore, and the presence or absence of volcanoes or volcanic vents. Some sediments, now represented by the Knoxville and Riddle Formations, were deposited in shallow to fairly shallow waters as mostly nonvoleanic, highly fossiliferous mud, silt, sand, and gravel and locally as limestone lenses. Other sediments, now represented by the Dothan and Otter Point Formations and by the lower part of the Franciscan assemblage, were deposited in moderately deep to deep waters as highly volcanic, rather poorly fossiliferous mud, silt, sand, gravel, chert, volcanic breccias, and lava flows. Deposition of all these sediments continued into Cretaceous time. All available evidence suggests that the volcanic sequences were deposited at least several hundred miles west of the nonvolcanic sequences and in much deeper water but that all marine deposition began at about the same time, after the formation of oceanic crust in late Oxfordian to early Kimmeridgian time.

In summation, Jurassic marine sediments in the Pacific Coast region were deposited in waters ranging from very shallow to very deep; involved tremendous thicknesses; included a great deal of volcanic material, except in the Knoxville Formation of California and the Riddle Formation of Oregon; and were deposited in troughs whose positions gradually shifted westward. Furthermore, the scarcity of red sediments suggests that deposition took place mainly under reducing conditions. The absence of gypsum and salt deposits implies that lagoonal conditions did not last long and that shorelines shifted frequently. The fact that no sediments were derived from the east, except for the Dunlap Formation of Ne- vada, implies that the landmass in central Nevada was generally low or shed most of its sediment eastward.

These conclusions are of little help in evaluating the kind of climate that existed in the Pacific Coast region during Jurassic time. However, the presence of ammonites that have Mediterranean affinities indicates that the waters were fairly warm. Thus, the Pliensbachian ammonite fauna in eastern Oregon is characterized by the families Hildoceratidae and Dactylioceratidae but lacks the Amaltheidae, which is common in northwest Europe and from British Columbia northward (Imlay, 1968 , p. C1, C21, C22). The Bajocian ammonites in Oregon and California include certain genera that are common in Europe but that are as yet unknown in Alaska (Imlay, 1973, p. 31, 36). The Callovian beds in those States lack Cadoceras, which is very common from British Columbia northward. Finally, the Tithonian beds of those States contain many ammonites of Mediterranean and South American affinities that are unknown from British Columbia northward (Imlay and Jones, 1970, p. B17-B19).

\section{WESTERN INTERIOR REGION}

During the Jurassic, most of the sediments deposited in the western interior region were derived from bordering areas on the southeast and north and from a persistently rising area in south-central Colorado. Some sediments were also derived from the west at certain times. Thus, during late middle to late Bajocian time, and again during earliest Callovian time, sand and pebbles derived from a landmass in south-central Idaho were deposited respectively as part of the Sliderock and Giraffe Creek Members of the Twin Creek Limestone (Imlay, 1967b, p. $22,23,26,30,50-53)$. Later, in the early Oxfordian, a northern extension of this landmass was the main source of sand deposited as parts of the Swift Formation and the Stump Sandstone (Imlay, 1957, p. 481-482; Imlay, Gardner, and others, 1948). Similarly, the sediments composing the Morrison Formation were derived from the west as well as from the south and northeast.

During Early Jurassic time, marine sediments were not deposited in the western interior of the United States or east of the foothills of the Canadian Rocky Mountains, so far as is known. A southeastward extension of marine waters into northwestern Montana is suggested by the presence of marine beds of Sinemurian and Toarcian Age near the International Boundary in southeastern British Columbia and in southwestern Alberta, but the facies present indicate deposition in very shallow waters near a southeastern shoreline (Frebold, 1969, p. 76, 78, 82, $84)$.

In contrast, continental sediments may have been deposited, in my opinion, during earliest Jurassic time over fairly wide areas in the southern and central parts 
of the western interior region. Near the border of Arizona and Utah, the earliest deposits (Moenave Formation) of possible Early Jurassic age were mostly fluviatile sand and silt. These sediments were succeeded from that border area northward to east-central Utah and to southwestern Colorado by fluviatile sand and silt (Kayenta Formation), which were interbedded with some eolian sand. Next followed deposition of buff to white, conspicuously crossbedded sand (Navajo Sandstone) of eolian origin over the same area as well as in eastern Nevada and northern Utah. Similar crossbedded sand (Nugget Sandstone and Glen Canyon Sandstone) was deposited at least in part at the same time in northernmost Utah, northwestern Colorado, southeastern Idaho, and western and central Wyoming. Its lower part, however, which contains some thin beds of ripple-marked, flat-bedded sand and silt, was probably deposited earlier than the Navajo Sandstone (Reeside, 1957, p. 1480, 1482; Pipiringos, 1968, p. D16, D17; Poole and Stewart, 1964, p. D38).

Early in Bajocian time, a very shallow sea entered the western interior region from the west across southeastern Idaho, western Wyoming, and northern Utah (fig. 32). It then enlarged itself northeastward through north-central and northeastern Wyoming into the Williston basin of eastern Montana, western North Dakota, and adjoining parts of Saskatchewan and Manitoba. The sediments it deposited now comprise the Nesson Formation of the Williston basin, the Gypsum Spring Formation farther south, and the Temple Cap Sandstone of southwestern Utah. Those sediments consist mostly of gypsum, even-bedded red to green silt and mud, laminated or dolomitic lime mud, and some chert nodules and layers. During the advance of the sea across Wyoming and Montana, the initial deposits were mainly gypsum interbedded with red silt and a little limy mud, but in the Williston basin they included some salt. These deposits are overlain by limy beds, some dark-gray chert, and some red silt. In southeastern Idaho, the sediments deposited in the same sea contained much less gypsum and much more limy mud and siliceous material (Imlay, 1967b, p. 21). A southward extension of the same sea into southwestern Utah deposited red, even-bedded silt and gypsum that to the east passed rather abruptly into crossbedded sand. Evidently the sea deepened toward the west both in Idaho and in Utah.

The initial sediments of the early Bajocian sea were deposited in very shallow, highly saline waters, as shown by an association of gypsum, red mud, silt, and locally some salt, and by an absence of any marine fossils. More limy sediments were deposited later in slightly deeper waters, as shown by the presence of some pelecypods, gastropods, echinoid spines, crinoid columnals, and worm tubes. An absence of ammonites in the limy rocks, how- ever, suggests that the sea waters were either very shallow or were more saline than normal. The characteristics of the sediments indicate that the landmasses bordering the sea were low and that the climate was warm to hot and seasonally humid.

Near the middle of the middle Bajocian, the sea withdrew westward completely from the western interior region. It returned to some areas, however, by the late middle Bajocian (Stephanoceras humphriesianum zone), and by late Bajocian time, it spread over a larger area than in the early part of the epoch. This rapid retreat and readvance of marine waters over such a large area during part of middle Bajocian time suggests that the western interior region had little relief, was near sea level, and consequently was flooded or drained in response to minor vertical movements of landmasses or of ocean basins. The unconformity that developed between floodings, although representing only a small part of middle Bajocian time, could have represented 1 million or 2 million years. It was sufficiently long for erosion and local removal of the Gypsum Spring Formation and equivalent beds and for the accumulation of a lag deposit of weathered, dark-gray chert nodules on the surface of that formation. Such nodules were then reworked by the incoming sea and scattered widely.

The shallow sea that entered the western interior region in late middle to late Bajocian time lasted into earliest Callovian time and even then did not completely withdraw from the region. During the late Bajocian and early Bathonian, it extended eastward across about twothirds of Utah, across the western third and north-central part of Wyoming, and across most of Montana into the Williston basin, except for some islands in central Montana. During late Bathonian time, the sea deepened and extended even farther east across northern Utah and Colorado and across Wyoming into western South Dakota. It shallowed somewhat during the earliest Callovian. It was also shallower in Utah than farther north, as shown by a southward increase in red beds and gypsum, a southward decrease in molluscan species, an absence of ammonites south of the northwestern part of the San Rafael Swell in central Utah, and an absence of Gryphaea south of Thistle in north-central Utah.

The first sediments deposited in the advancing sea during late middle to early late Bajocian time filled in the irregularities of the underlying erosion surface and consequently varied lithologically within moderate distances. The initial deposits include normal shallow-water marine shale and limestone containing Gryphaea and ammonites (Sliderock Member of the Twin Creek Limestone), gypsiferous shale (lower member of the Piper Formation), and massive crossbedded sand (Page Sandstone near Hanna, Utah). Succeeding sediments of latest Bajocian Age were deposited in slightly deeper water in 

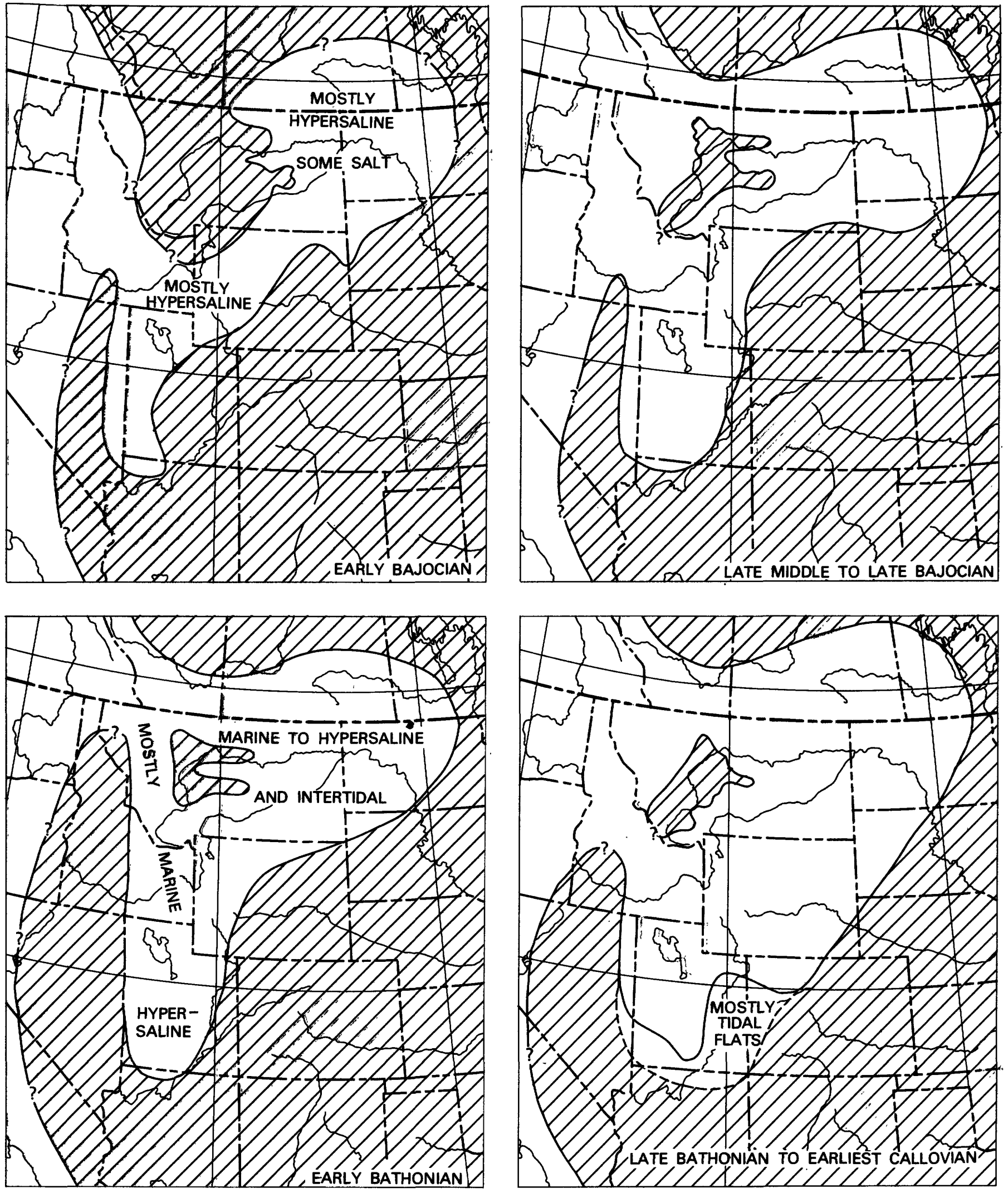

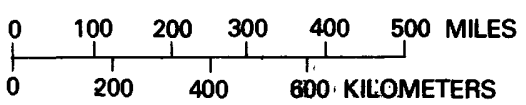

FIGURE 32.- Inferred extent of Jurassic seas of early Bajocian to earliest Callovian Age in western interior region. Land areas are ruled. Modified from McKee and others (1956), Frebold (1957), Imlay; (1957), J.. A. Peterson (1957), and Springer and others (1966). 
broad, fairly uniform basins. Consequently, they maintain their lithologic and stratigraphic characteristics over considerable distances. Thus, during latest Bajocian time, oolitic to dense highly fossiliferous gray lime mud was deposited over nearly the entire seaway from Idaho to South Dakota and from Saskatchewan to southwestern Utah.

During early Bathonian time, the sea became shallower and a little more restricted than in latest Bajocian time. It was definitely hypersaline in southernmost Utah, as shown by an association of red silt and considerable gypsum (banded member of the Carmel Formation). It was definitely of normal salinity in western and northcentral Montana, as shown by an association of fossiliferous sandstone, siltstone, and limestone. It probably varied elsewhere from shallow marine to littoral or lagoonal, as shown by an association of variegated siltstone with silty to sandy limestone and locally a little gypsum.

During late Bathonian time, limy mud was deposited in shallow to moderately shallow marine waters over most of the western interior seaway as far south as the western part of the Uinta Mountains in northern Utah. Farther south in Utah, the limy mud (Watton Canyon and Leeds Creek Members of the Twin Creek Limestone) passes laterally into variegated sand, silt, limestone, and gypsum (Winsor Member and gypsiferous member of the Carmel Formation), which in places were deposited under hypersaline conditions. Southeastward from the Wind River Basin across south-central and southeastern Wyoming, the limy mud (Stockade Beaver Shale Member of the Sundance Formation) was gradually replaced entirely from the base upward by oolitic sand (Canyon Springs Sandstone Member of the Sundance Formation), which was deposited by the southeastward advancing sea partly in very shallow water and partly in intertidal and supratidal environments. Deepening of the sea northwestward across Wyoming is attested by the pelecypod Gryphaea being rare throughout central and eastern Wyoming but abundant from the Bighorn Basin northward. This change in abundance coincides roughly with the position of the northeastwardtrending Sheridan arch, as discussed by Wright (1973, p. 13).

During earliest Callovian time, the sea became shallower than during late Bathonian time, as shown by deposition of fossiliferous ripple-marked sand throughout most of the central part of the western interior region and of nonfossiliferous variegated clay, silt, sand, and some gypsum in central and northern Utah. The deposition of fossiliferous chalky limestone in north-central Montana at that time shows that marine circulation in the Williston basin was unrestricted.

Near the middle of the early Callovian, a large island arose in Montana and northwestern Wyoming that even- tually cut off the southern part of the sea from marine waters to the north but not from those to the west (fig. 33) (Imlay, 1952b, p. 1745, 1751-1753; 1957, p. 487, 490). Southeast, south, and southwest of this island, red, even-bedded, fine-grained sandstone, silty sandstone, and shale were deposited in very shallow waters along a strip 100-150 miles (160-240 km) wide. Beds generally less than 100 feet $(30$ m) thick were deposited (Lak Member of Sundance Formation) in the eastern and southern parts of the strip; beds $400-1,800$ feet (122-549 m) thick (Preuss Sandstone), in the Twin Creek trough in the western part of the strip; and beds more than 400 feet $(122 \mathrm{~m})$ thick (Entrada Sandstone), along the west side of the San Rafael Swell in central Utah.

Red beds deposited along the Idaho-Wyoming border and as far south as the Nephi area in Utah differ from those to the east and west by having bedded salt and a little gypsum in their lower third (Mansfield, 1927, p. 99, 338-340; Spieker, 1946, p. 124; Eardley, 1933, p. 330334; Hardy, 1952, p. 21, 22, 91). To the west, red beds near Blackfoot and Idaho Falls, Idaho, differ from those farther east by having nearly 200 feet $(61 \mathrm{~m})$ of fossiliferous marine limestone and red sandstone at about the same stratigraphic position as the salt. These fossiliferous limestone and unfossiliferous red sandstone beds extend eastward as a thin unit to within a few miles of Afton, Wyo. (Imlay, 1952b, p. 1739-1746; 1957, p. 497).

These red beds were deposited at the same time as some light-colored, crossbedded sands (Entrada Sandstone) in the Colorado Plateau area, as is shown by intertonguing and interbedding of the two facies over large areas (Imlay, 1957, p. 480-490). These relationships show that deposition took place alternately on land and in shallow waters and imply that the bordering land areas were low.

These relations and the lithologic character of the rocks deposited show that a shallow sea of normal salinity existed in eastern Idaho during late early Callovian time and perhaps during part of middle Callovian time. The salt and gypsum were deposited a little farther east in lagoons or in stagnant water near the shore; the unfossiliferous, red, silty to fine-grained sandstones were deposited still farther east in Utah, Wyoming, and western South Dakota in highly saline rather than in brackish waters. The red sediments were probably derived mostly from an island in Montana on which lateritic soils had developed under a warm and seasonally rainy climate. The light-colored crossbedded sands that were deposited at the same time in the Colorado Plateau area presumably were derived from an uplift in west-central or southern Colorado, are at least partly eolian in origin, and formed under a hot and arid climate.

This red, even-bedded fine-grained sand and silt of late early to possible middle Callovian Age was overlain 

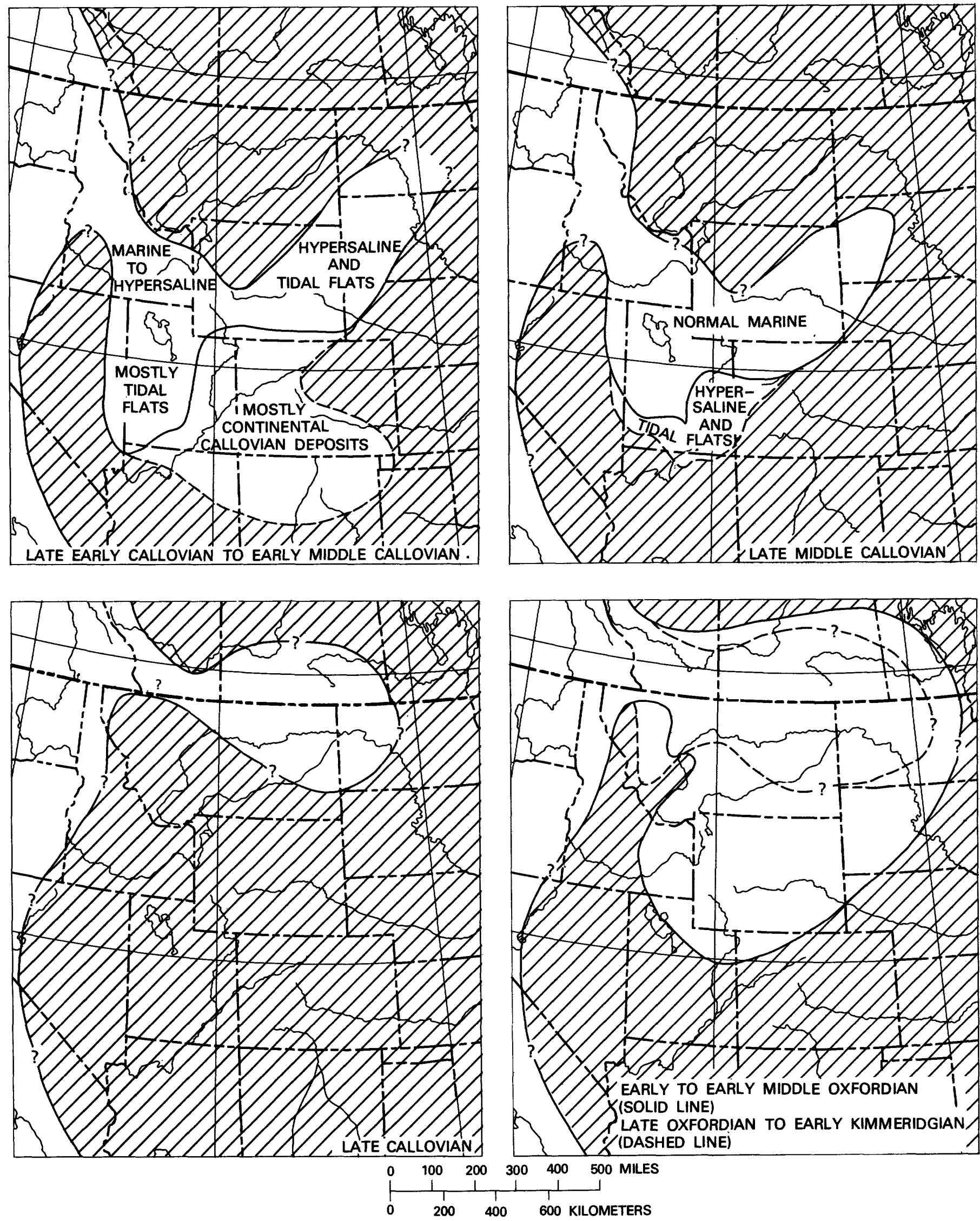

FIGURE 33.-Inferred extent of Jurassic seas of late early Callovian to early Kimmeridgian Age in western interior region. Land areas are ruled. Modified from McKee and others (1956), Frebold (1957), Imlay (1957), J. A. Peterson (1957), and Springer and others (1966). 
by shallow-water marine, green to gray glauconitic sand, silt, and clay. In western South Dakota, southern Wyoming, and northern Colorado, these glauconitic sediments (Pine Butte Member of the Sundance Formation) were deposited gradationally on the red Lak Member of the Sundance Formation. In north-central and northeastern Utah, these glauconitic sediments (Curtis Formation) were deposited unconformably in most places on the Preuss Sandstone or on the red earthy facies of the Entrada Sandstone. Similar glauconitic sediments in southeastern Idaho and in bordering parts of Wyoming and Utah (Curtis Member of the Stump Sandstone) were deposited conformably and gradationally on the Preuss Sandstone.

The sea of Curtis-Pine Butte time must have been very shallow except in its westernmost part. This conclusion is based on the presence of Ostrea, Lopha, Lingula, and Meleagrinella in the Pine Butte Member of the Sundance, the presence of Ostrea and Meleagrinella in the type section of the Curtis Formation on the San Rafael Swell, and the general scarcity of other pelecypods. It is based also on the fact that the glauconitic sediments of the Curtis Formation on the swell pass laterally southeastward and grade vertically into unfossiliferous, brown or gray, locally gypsiferous, even-bedded sandstone, siltstone, and clay (Summerville Formation) that probably originated under lagoonal to highly saline conditions. The westernmost occurrences of the Curtis Formation were deposited in slightly deeper waters, as shown by (1) the presence of Gryphaea with Ostrea and Meleagrinella in Salina Creek Canyon east of Salina, Utah (USGS Mesozoic loc. 21646) and (2) the presence of belemnites and the ammonite Lytoceras in Monks Hollow, about 18 miles $(29 \mathrm{~km})$ southeast of Provo, Utah. The distribution of these cephalopods indicates that the sea entered from the west.

The age of the Curtis-Pine Butte beds is not precisely known. It is considered to be middle Callovian because those beds are overlain unconformably by beds of early Oxfordian Age, grade downward into the Preuss Sandstone of early to possibly early middle Callovian Age, and contain the pelecypods Vaugonia conradi (Meek and Hayden) and Myophorella montanaensis (Meek), which occur elsewhere only in older Middle Jurassic beds (Imlay, 1967b, p. 14).

During Curtis-Pine Butte time, the climate was warm and presumably more rainy than during deposition of the underlying red beds.

Marine waters withdrew from the western interior region at about the end of the middle Callovian. This withdrawal was followed by erosion during the late Callovian at least as far south as the San Rafael Swell in northeastern Utah (Pipiringos and O'Sullivan, 1978) and probably as far south as northern Arizona (Fred Peterson, 1974, p. 466). Erosion apparently was slight in the central and southern parts of the region and was greatest in centrai and northwestern Montana in the Belt Island area.

Near the end of the Callovian, a sea entered central Montana and the Williston basin area from the northwest across southern Alberta. During the early Oxfordian, this sea spread eastward into South Dakota, southward into northwestern Colorado and northern Utah, westward across Wyoming into southeastern Idaho, and westward in Montana at least as far as the eastern side of the Sweetgrass arch. At the end of the early middle Oxfordian (Perisphinctes plicatilis zone), the sea withdrew northward at least as far as the Williston basin area, but it expanded westward in Montana as far as the Sawtooth Range south of Glacier Park, as shown by the presence of Buchia concentrica (Sowerby) near the base of the Swift Formation in that range. The fossil evidence suggests that the sea in northern Montana persisted until at least the end of the Oxfordian and possibly into the early Kimmeridgian.

The initial retreat of the sea near the middle of the Oxfordian was followed in western South Dakota, eastern and southern Wyoming, northwestern Colorado, and northeastern Utah by a brief readvance, during which a very thin marine unit (Windy Hill Sandstone Member of the Sundance Formation) was deposited disconformably on middle Callovian to lower Oxfordian marine beds (Pipiringos, 1968, p. D23, D25). As this thin marine unit has not been recognized in north-central Wyoming or in Montana, it is assumed to have been deposited at the same time as the upper part of the Oxfordian marine beds lying conformably below the Morrison Formation in that area.

The sea of latest Callovian to Oxfordian Age did not extend south of northern Colorado or northern Utah, so far as is known. It probably did not enter the western interior region through either southern Idaho or western Montana, because the sediments deposited become coarser westward and in western Montana they contain many wood fragments. Also, the age of the basal sediments in Montana changes westward from latest Callovian in the Little Rocky Mountains of central Montana to late Oxfordian in the Sawtooth Range of northwestern Montana. This evidence indicates the presence of a landmass to the west that shed considerable clastic sediment into the sea. In western Montana at least, this landmass was gradually submerged during the late Oxfordian.

The marine sediments deposited in the western interior during latest Callovian and Oxfordian time changed from mostly silt and clay on the east to mostly glauconitic, calcareous sand, sandy coquinoid lime mud, and sandy silt on the west (Cobban, 1945, p. 1281-1286; Imlay, Gardner, and others, 1948; Imlay, 1956a, p. 595597; Pipiringos, 1968, p. D23; Brenner and Davies, 1974). The basal contact of sediments deposited in the 
eastern part of the sea is sharp and is characterized by an abundance of belemnites (some of which are water worn), or by a few pebbles, or by a grit bed. The basal contact of sediments deposited in the western part of the sea is similar but is generally marked by pebbles of limestone, chert, or quartzite or by highly glauconitic sand in addition to many belemnites. Deposition of the sediments in shallow water is shown by the presence of a varied peleeypod fauna including Ostrea and Mytilus. The climate was probably warm and rainy.

The Morrison Formation was deposited during Late Jurassic time in fluviatile and lacustrine environments throughout much of the western interior region (Reeside, 1952; Craig and others, 1955, fig. 30, p. 159). In Montana, as far north as the Great Falls area, its upper part was deposited in coal-forming swamps. Deposition began during the late Oxfordian in Wyoming and bordering parts of Utah and Colorado, probably began at the same time or slightly earlier in areas farther south, but probably began in the Kimmeridgian in northern Montana. This northward change in age of the basal Morrison coincides with northward thinning of the formation across Montana to a pinch-out near the Canadian boundary. These relations, especially including the persistence of coaly beds at the top of the Morrison in Montana, suggest that continental deposition in the south coincided with marine deposition in the north during late Oxfordian time and that the northward pinch-out of the continental Morrison is not primarily due to post-Morrison erosion. In all parts of the western interior region, deposition of continental beds persisted during the Kimmeridgian and may have continued into the early Tithonian, as is shown by the freshwater mollusks and vertebrate fossils present (Yen, 1952, p. 31-34; Reeside, 1952, p. 25; Imlay, 1952a, p. 953, 958). The climate during Morrison time apparently varied from warm and semiarid to warm and humid (Craig and others, 1955, p. 152, 157).

\section{REFERENCES CITED}

Albee, H. F., 1968, Geologic map of the Munger Mountain quadrangle, Teton and Lincoln Counties, Wyoming: U.S. Geol. Survey Geol. Quad. Map GQ-705.

Albritton, C. C., Jr., 1987, Upper Jurassic and Lower Cretaceous ammonites of the Malone Mountains, Trans-Pecos Texas: Harvard College Mus. Comparative Zoology Bull., v. 80 , no. 10, p. 391412, pls. $1-9$.

1938, Stratigraphy and structure of the Malone Mountains, Texas: Geol. Soc. America Bull., v. 49, p. 1747-1806, pls. 1-9. Amoco Canada Petroleum Company Limited and Imperial Oil Limited, Offshore Exploration Staffs, 1974, Regional geology of Grand Banks: Am. Assoc. Petroleum Geologists Bull., v. 58, no. 6, pt. 2 , p. 1109-1123, 19 figs.
Andrews, D. I., 1960, The Louann salt and its relationship to Gulf Coast salt domes: Gulf Coast Assoc. Geol. Socs. Trans., v. 10, p. 215-240, 9 text figs.

Applin, P. L., and Applin, E. R., 1944, Regional subsurface stratigraphy and structure of Florida and southern Georgia: Am. Assoc. Petroleum Geologists Bull., v. 28, no. 12, p. 1673-1753.

1953, The cored section in George Vasen's Fee well, one, Stone County, Mississippi: U.S. Geol. Survey Circ. 298, 29 p.

1965, The Comanche Series and associated rocks in the subsurface in central and south Florida: U.S. Geol. Survey Prof. Paper 447,84 p., 53 text figs.

Arkell, W. J., 1939, The ammonite succession at the Woodham Brick Company's pit, Akeman Street Station, Buckinghamshire, and its bearing on the classification of the Oxford Clay: Geol. Soc. London Quart. Jour., v. 95, p. 135-222, pls. 8, 9.

1946, Standard of the European Jurassic: Geol. Soc. America Bull., v. 57, p. 1-34.

1954, The ammonites and their place in the Bajocian faunas of the world, in Arkell, W. J., and Playford, P. E., The Bajocian ammonites of Western Australia: Royal Soc. [London] Philos. Trans., ser. B., Biol. Sci., no. 651, v. 237, p. 548-604.

1956, Jurassic geology of the world: London, Oliver \& Boyd, 806 p., 102 figs., 46 pls.

Arkell, W. J., and others, 1957, Mesozoic Ammonoidea, in Moore, R. C., ed., Treatise on invertebrate paleontology, pt. L, Mollusca 4Cephalopoda, Ammonoidea: New York, Geol. Soc. America, and Lawrence, Univ. Kansas Press, 490 p.

Armstrong, R. L., and Besancon, James, 1970, A Triassic time scale dilemma: K-AR dating of Upper Triassic rocks, eastern U.S.A. and Canada and post-Upper Triassic plutons, western Idaho, U.S.A.: Ecologae Geol. Helvetiae, v. 63, p. 15-28, 4 figs.

Ascoli, P., 1974, Biostratigraphic zonation (Foraminifera and Ostracoda) of the Mesozoic and Cenozoic rocks of the Atlantic Shelf: Canada Geol. Survey Paper 74-1, pt. B, p. 133-135.

Averitt, Paul, 1962, Geology and coal resources of the Cedar Mountain quadrangle, Iron County, Utah: U.S. Geol. Survey Prof. Paper 389,72 p., 3 pls., 22 figs.

Badon, C. L., 1975, Stratigraphy and petrology of Jurassic Norphlet Formation, Clarke County, Mississippi: Am. Assoc. Petroleum Geologists Bull., v. 59, p. 377-392, 9 figs.

Bailey, E. H., Blake, M. C., Jr., and Jones, D. L., 1970, On-Land Mesozoic oceanic crust in California coast ranges: U.S. Geol. Survey Prof. Paper 700-C, p. C70-C81, 6 figs.

Bailey, E. H., Irwin, W. P., and Jones, D. L., 1964, Franciscan and related rocks and their significance in the geology of western California: California Div. Mines and Geology Bull. 183, 177 p., 2 pls., 35 figs., 82 photos.

Baker, A. A., 1946, Geology of the Green River Desert-Cataract Canyon region, Emery, Wayne and Garfield counties, Utah: U.S. Geol. Survey Bull. 951, 122 p., 20 pls., 3 figs.

1947, Stratigraphy of the Wasatch Mountain in the vicinity of Provo, Utah: U.S. Geol. Survey Oil and Gas Inv. Prelim. Chart 30.

Baker, A. A., Dane, C. H., and Reeside, J. B., Jr., 1936, Correlation of the Jurassic formations of parts of Utah, Arizona, New Mexico and Colorado: U.S. Geol. Survey Prof. Paper, 183, 66 p., 26 pls., 16 figs.

Baker, A. A., Dobbin, C. E., McKnight, E. T., and Reeside, J. B., Jr., 1927, Notes on the stratigraphy of the Moab region, Utah: Am. Assoc. Petroleum Geologists Bull., v. 11, p. 785-808.

Ballard, R. D., and Uchupi, Elazar, 1974, Geology of Gulf of Maine: Am. Assoc. Petroleum Geologists Bull., v. 58, no. 6, pt. 2, p. 1156-1158, 1 fig. 
Barksdale, J. D., 1975, Geology of the Methow Valley, Okanogan County, Washington: Washington Div. Geology and Earth Resources Bull. 68, 72 p., pl. 11, 17 figs.

Bartlett, G. A., and Smith, Leigh, 1971, Mesozoic and Cenozoic history of the Grand Banks of Newfoundland: Canadian Jour. Earth Sci., v. 8 , no. 1 , p. $65-84,2$ text figs.

Bateman, P. C., Clark, L. D., Huber, N. K., Moore, J. G., and Rinehart, C. D., 1963, The Sierra Nevada batholith-a synthesis of recent work across the central part: U.S. Geol. Survey Prof. Paper 414-D, 46 p.

Bateman, P. C., and Wahrhaftig, Clyde, 1966, Geology of the Sierra Nevada, in Geology of northern California: California Div. Mines and Geology Bull. 190, p. 107-172, 17 figs., 23 photos.

Beaulieu, J. D., 1971, Geologic formations of western Oregon: Oregon Dept. Geology and Mineral Industries Bull. 70, 72 p., correlation charts.

Becker, G. F., 1885, Notes on the stratigraphy of California: U.S. Geol. Survey Bull. 19, 28 p.

Berg, H. C., Jones, D. L., and Richter, D. H., 1972, Gravina-Nutzotin belt-tectonic significance of an upper Mesozoic sedimentary and volcanic sequence in southern and southeastern Alaska: U.S. Geol. Survey Prof. Paper 800-D, p. D1-D24.

Berggren, W. A., and Hollister, C. D., 1974, Paleogeography, paleobiogeography and the history of circulation in the Atlantic Ocean, in Studies in paleo-oceanography: Soc. Econ. Paleontologists and Mineralogists Spec. Pub. 20, p. 126-186, 22 figs.

Bermudez, P. J., 1961, Las formaciones geologicas de Cuba: Cuba Inst. Recursos Minerales, Geología Cubana no. 1, 177 p., 2 figs.

Bernoulli, Daniel, 1972, North Atlantic and Mediterranean Mesozoic facies-a comparison: California Univ., Scripps Inst. Oceanography, La Jolla, Initial Repts. Deep Sea Drilling Project, v. 11, p. 801-822, 6 figs.

Bernoulli, Daniel, and Jenkyns, H. C., 1974, Alpine, Mediterranean, and central Atlantic Mesozoic facies in relation to the early evolution of the Tethys, in Modern and ancient geosynclinal sedimentation: Soc. Econ. Paleontologists and Mineralogists Spec. Pub. 19, p. 129-160, 8 figs.

Birkelund, 'Tove, Hakansson, Eckart, and Surlyk, Finn, 1971, New finds of Bathonian, Callovian, and Oxfordian ammonites in northern Jameson Land, East Greenland: Dansk Geol. Foren. Medd., v. 20 , pt. 3, p. $240-259,2$ pls., 3 figs.

Bishop, W. F., 1967, Age of Pre-Smackover formations, north Louisiana and south Arkansas: Am. Assoc. Petroleum Geologists Bull., v. 51 , no. 2 , p. $244-250$.

1973, Late Jurassic contemporaneous faults in north Louisiana and south Arkansas: Am. Assoc. Petroleum Geologists Bull., v. 57, no. 5, p. 858-877.

Blanchet, F., 1923, La faune du Tithonique inferieur des régions subalpines et ses rapports avec celle du Jura franconien: Soc. Géol. France Bull., ser. 4., v. 23, p. 70-80.

Bonet, Federico, 1956, Zonificación microfaunistica de las calizas Cretácicas del este de México: Asoc. Mexicana Géologos Petroleros Bol., v. 8, nos. 7-8, p. I-IV, $389-488,35$ pls.

Bourquin, J. D. R., 1967, 1968, Les Reinéckeidés: Besancon Univ. ser. 3, no. 4,169 p. (1968) 51 pls., 30 text figs. (1967).

Brenner, R. L., and Davies, D. K., 1974, Oxfordian sedimentation in western interior United States: Am. Assoc. Petroleum Geologists Bull., v. 58 , no. 3 , p. $407-428,25$ text figs.

Bridges, L. W., 2d, 1965, Estudios geológicos en el Estado de Chihuahua-Pt. 1, Geología del área de Plomosas, Chihuahua: México Univ. Nac. Autonoma Inst. Geología Bol. 74, p. 1-134, illus., tables, geologic map.
Bronnimann, Paul, 1954, On the occurrence of Calpionellids in Cuba: Eclogae Geol. Helvetiae (1953), v. 46, no. 2, p. 263-268.

Brooke, M. M., and Braun, W. K., 1972, Biostratigraphy and microfaunas of the Jurassic system of Saskatchewan: Saskatchewan Dept. Mineral Resources Rept. 161, 23 p., 26 pls., 9 text figs., 23 charts.

Brooks, H. C., 1967, Distinctive conglomerate layer near Lime, Baker County, Oregon: Ore Bin, v. 29, no. 6, p. 113-119.

Brown, A. S., 1968, Geology of the Queen Charlotte Islands, British Columbia: British Columbia Dept. Mines and Petroleum Resources Bull. 54, p. 3-226, 18 pls., 45 figs.

Brown, C. E., and Thayer, T. P., 1966a, Geologic map of the Canyon City quadrangle, northeastern Oregon: U.S. Geol. Survey Misc. Geol. Inv. Map I-447.

-1966b, Geologic map of the Mount Vernon quadrangle, Grant County, Oregon: U.S. Geol. Survey Geol- Quad. Map GQ-548.

Brown, P. M., Miller, J. A., and Swain, F. M., 1972, Structural and stratigraphic framework, and spatial distribution of permeability in the Atlantic Coastal Plain, North Carolina to New York: U.S. Geol. Survey Prof. Paper 796, 79 p., 59 pls., 13 figs.

Buddenhagen, H. J., 1967, Structure and orogenic history of the southwestern part of the John Day Uplift, Oregon: Ore Bin, v. 29, no. 7, p. $129-138$.

Burckhardt, Carlos, 1906, La faune Jurassique de Mazapil avec un appendice sur les fossiles du Crétacique Inferieur: Inst. Geol. México Bol. 23, 216 p., 43 pls.

1912, Faunes jurassiques et crétaciques de San Pedro del Gallo: Inst. Geol. México Bol. 29, 264 p., 46 pls.

-1919 , 1921, Faunas Jurásicas de Symon (Zacatecas): Inst. Geol. México Bol. 33, 135 p., 32 pls.

1927, Cefalópodos del Jurásico medio de Oaxaca y Guerrero: Inst. Geol. México Bol. 47, 108 pp., 34 pls.

-1930-1931, Étude synthétique sur le Mésozoique Méxicain: Soc. paléont. Suisse Mém., v. 49, p. 1-123, 32 figs. (1930); v. 50, p. 123-280, 22 figs. (1931).

Callomon, J. H., 1955, The ammonite succession in the lower Oxford clay and Kellaways beds at Kidlington, Oxfordshire, and the zones of the Callovian Stage: Royal Soc. [London] Philos. Trans., Bull. 239 , p. 215-264.

1959, The ammonite zones of the Middle Jurassic beds of East Greenland: Geol. Mag., v. 96, no. 6, p. 505-513, pls. 17-18.

1964, Notes on the Callovian and Oxfordian stages, in Colloque du Jurassique (Luxembourg, 1962): Luxembourg, Inst. Grand-ducal, Sec. Sci. Nat., Phys., Math., p. 269-291.

Callomon, J. H., Donovan, D. T., and Trumpy, Rudolf, 1972, An annotated map of the Permian and Mesozoic formations of East Greenland: Medd. on Grønland, v. 168, no. 3, p. 1-36, 9 figs., 3 tables.

Cantú Chapa, Abelardo, 1963, Étude biostratigraphique des Ammonites du centre et de l'est du Mexique (Jurassique supérieur et Crétacé): Soc. Geol. France Mem. 99 new ser., v. 42, pt. 4, 102 p., 8 pls.

-1967, El límite Jurásico-Cretácico en Mazatepec, Puebla, in Estratigrafía del Jurásico de Mazatepec, Puebla (México): Inst. Mexicano Petróleo Techología Exploro Secc. Geología Monografia 1, p. 3-24, 7 pls., 5 figs.

1968, Sobre una asociacion Proniceras- Durangites - "Hildoglochiceras" del Noreste de Mexico: Inst. Mexicano petróleo, Secc. Geología Mon. 2, p. 19-26, 5 pls., 1 fig.

1969, Estratigrafía del Jurasico Medio-superior del subsuelo de Poza Rica, Ver. (Area de Soledad-Miquetla): Inst. Mexicano Petróleo Rev., v. 1., no. 1, p. 3-9, 1 fig. 
1970, El kimeridgiano inferior de Samalayuca, Chihuahua: Inst. Mexicano Petroleo Rev., v. 2, no. 3, p. 40-44, 1 pl., 1 fig.

1971, La serie Huasteca (Jurásico medio-superior) del centro este de Mexico: Inst. Mexicano Petróleo Rev., v. 3, no. 2, p. 1740, 4 figs.

1973, Huasteca Series (middle and upper Jurassic) and its relation with Poza Rica reservoir, Mexico [abs.]: Am. Assoc. Petroleum Geologists Bull., v. 57, no. 4, p. 772.

Cariou, Élie, Elmi, Serge, Mangold, Charles, Thierry, Jacques, and Tintant, Henri, 1971, Les zones du Jurassique en France-Callovien (province subméditerranéenne): Soc. Géol. France Compte Rendu, no. 2, p. 91-93.

Cariou, Elie, Enay, Raymond, and Tintant, Henri, 1971, Les zones du Jurassique en France-Oxfordien (province submediterranéenne): Soc. Géol. France Compte Rendu, no. 2, p. 93-96.

Carlson, C. E., 1968, Triassic-Jurassic of Alberta, Saskatchewan, Manitoba, Montana, and North Dakota: Am. Assoc. Petroleum Geologists Bull., v. 52, p. 1969-1983, 11 figs.

Carrillo-Bravo, Jose, 1961, Geologia del Anticlinorio Huizachal-Peregrina al N-W de Ciudad Victoria Tamps.: Asoc. Mexicana Géologos Petroleros Bol., v. 13, p. 1-98, geol. map, cross sections, correlation chart, and photographs.

-1963, Geology of the Huizachal-Peregrina anticlinorium northwest of Ciudad Victoria, Tamaulipas, in Geology of Peregrina Canyon and Sierra del Abra, Mexico: Corpus Christi Geol. Soc. Ann. Field Trip 1963, p. 11-23, 5 text figs.

1965, Estudio geológico de una parte del Anticlinorio de Huayacocotla: Asoc. Mexicana Geólogos Petroleros Bol., v. 17, p. 73-96, geologic map, cross sections, and correlation chart.

Cashion, W. B., 1967, Carmel Formation of the Zion Park region, southwestern Utah-a review: U. S. Geol. Survey Bull. 1244-J, p. J1-J9, 2 figs.

Cater, F. W., and Craig, L. C., 1970, Stratigraphy, in Cater, F. W., Geology of the salt anticline region, southwestern Colorado: U.S. Geol. Survey Prof. Paper 637, p. 5-50 [1971].

Cater, F. W., and Wells, F. G., 1953, Geology and mineral resources of the Gasquet quadrangle, California-Oregon: U.S. Geol. Survey Bull. 995-C, p. 79-133 [1954].

Christopher, J. E., 1964, The Middle Jurassic Shaunavon Formation of southwestern Saskatchewan: Saskatchewan Dept. Mineral Resources Rept. 95, 95 p., 13 pls., 27 figs.

1974, The Upper Jurassic Vanguard and Lower Cretaceous Mannville Groups of southwestern Saskatchewan: Saskatchewan Dept. Mineral Resources Rept. 151, 349 p., 4 pls., 51 figs.

Clark, L. D., 1964, Stratigraphy and structure of part of the western Sierra Nevada metamorphic belt, California: U.S. Geol. Survey Prof. Paper 410, 70 p., pls. 1-11.

Clark, L. D., Imlay, R. W., McMath, V. E., and Silberling, N. J., 1962, Angular unconformity between Mesozoic and Paleozoic rocks in the northern Sierra Nevada, California: U.S. Geol. Survey Prof. Paper 450-B, p. B15-B19, illus.

Cobban, W. A., 1945, Marine Jurassic formations of Sweetgrass arch, Montana: Am. Assoc. Petroleum Geologists Bull., v. 29, p. 12621303, 6 figs.

Cobban, W. A., and Reeside, J. B., Jr., 1952, Correlation of the Cretaceous formations of the Western Interior of the United States: Geol. Soc. America Bull., v. 63, p. 1011-1043, illus.

Cohee, G. V., 1965, Geologic history of the Michigan Basin: Washington Acad. Sci. Jour., v. 55, no. 9, p. 211-223, 4 figs.

Contreras, V. H., and Castillon, B. M., 1968, Morphology and origin of salt domes of Isthmus of Tehuantepec: Am. Assoc. Petroleum Geologists Mem. 8, p. 244-260.

Cope, J. C. W., 1967, The paleontology and stratigraphy of the lower part of the upper Kimmeridge Clay of Dorset: British Mus. (Nat. History) Bull., Geology, v. 15, no. 1, 79 p., 33 pls., 12 figs.
Cornet, Bruce, and Traverse, Alfred, 1975, Palynological contributions to the chronology and stratigraphy of the Hartford Basin in Connecticut and Massachusetts: Geoscience and Man, v. 11, p. 1-33, 8 pls., 5 text figs.

Cornet, Bruce, Traverse, Alfred, and McDonald, N. G., 1973, Fossil spores, pollen and fishes from Connecticut indicate Early Jurassic age for part of the Newark Group: Science, v. 182, no. 4118, p. 1243-1246, 3 figs.

Corvalan, J. I., 1962, Early Mesozoic biostratigraphy of the Westgate area, Churchill County, Nevada: Stanford, Calif., Stanford Univ., unpub. Ph.d. thesis. (Dissert. Abs., v. 23, no. 6, p. 2092.)

Cragin, F. W., 1905, Paleontology of the Malone Jurassic formation of Texas: U.S. Geol. Survey Bull. 226, 172 p., 29 pls.

Craig, L. C., Holmes, C. N., Cadigan, R. A., Freeman, V. L., Mullens, T. E., and Weir, G. W., 1955, Stratigraphy of the Morrison and related formations, Colorado Plateau region-a preliminary report: U.S. Geol. Survey Bull. 1009-E, p. 125-168, figs. 19-31.

Cressman, E. R., 1964, Geology of the Georgetown Canyon-Snowdrift Mountain area, southeastern Idaho: U.S. Geol. Survey Bull. 1153,105 p., 7 pls., 8 figs.

Crickmay, C. H., 1930, Fossils from the Harrison Lake area, British Columbia: Canada Natl. Mus. Bull. 63 , p. 33-68, pls. $8-23,7$ figs.

1931, Jurassic history of North America, its bearing on the development of continental structure: Am. Philos. Soc. Proc., v. 70, p. 15-102, 14 paleogeographic maps., 2 figs.

1933a, Some of Alpheus Hyatt's unfigured types from the Jurassic of California: U.S. Geol. Survey Prof. Paper 175-B, p. 5164 , pls. 14-18.

1933b, Mount Jura investigation: Geol. Soc. America Bull., v. 44 , no. 5, p. 895-926, pls. 23-34.

1936, Study in the Jurassic of Wyoming: Geol. Soc. America Bull., v. 47, p. 541-564, 3 pls.

1962, Gross stratigraphy of Harrison Lake area, British Columbia: Calgary, Alberta, Evelyn deMille Books (published by author), pt. 8, p. 1-12.

Dallmeyer, R. D., 1975, The Palisades sill-a Jurassic intrusion? Evidence from $40 \mathrm{Ar} / 39 \mathrm{Ar}$ incremental release ages: Geology, v. 3, no. 5 , p. $243-245$.

Dane, C. H., 1935, Geology of the Salt Valley anticline and adjacent areas, Grand County, Utah: U.S. Geol. Survey Bull. 863, 184 p. [1936].

Dean, W. T., Donovan, D. T., and Howarth, M. K., 1961, The Liassic ammonite zones and subzones of the north-west European province: British Mus. (Nat. History) Bull., Geology, v. 4, no. 10, p. 437-505, pls. 63-75.

Detterman, R. L., and Hartsock, J. K., 1966, Geology of the IniskinTuxedni region, Alaska: U.S. Geol. Survey Prof. Paper 512, 78 p., 6 pls., 7 figs.

Diaz-Lozano, Enrigue, 1916, Descripcion de unas plantas líasicas de Huayacocotla, Vera Cruz; algunas plantas de la flora líasica de Huauchinago, Puebla: Inst. Geol. Mexico Bol. 34, 18 p.

Dickinson, K. A., 1968, Upper Jurassic stratigraphy of some adjacent parts of Texas, Louisiana, and Arkansas: U.S. Geol. Survey Prof. Paper 594-E, p. E1-E25, 1 pl., 13 text figs.

Dickinson, W. R., 1962, Petrogenetic significance of geosynclinal andesitic volcanism along the Pacific margin of North America: Geol. Soc. America Bull., v. 73, p. 1241-1256, 2 figs.

Dickinson, W. R., and Vigrass, L. W., 1964, Pre-Cenozoic history of Suplee-Izee district, Oregon-implications for geosynclinal theory: Geol. Soc. America Bull., v. 75, p. 1037-1044, 2 figs.

1965, Geology of the Suplee-Izee area, Crook, Grant, and Harney Counties, Oregon: Oregon Dept. Geology and Mineral Industries Bull. 58, 109 p. 
Diller, J. S., 1892, Geology of the Taylorsville region of California: Geol. Soc. America Bull., v. 3, p. 369-394.

1895, Description of the Lassen Peak sheet [California]: U.S. Geol. Survey Geol. Atlas, Folio 15, 4 p., maps.

1906, Description of the Redding quadrangle [California]: U.S. Geol. Survey Geol. Atlas, Folio 138, 14 p., maps.

1907, The Mesozoic sediments of southwestern Oregon: Am. Jour. Sci., 4th ser., v. 23, p. 401-421.

1908 , Geology of the Taylorsville region, Calif.: U.S. Geol. Survey Bull. 353, 128 p., map.

Dinkins, T. H., Jr., 1968, Jurassic stratigraphy of central and southern Mississippi, in Jurassic stratigraphy of Mississippi: Mississippi Geol., Econ. and Topog. Survey Bull. 109, p. 9-37.

Donovan, D. T., 1957, The Jurassic and Cretaceous systems in East Greenland: Medd. Grønland, v. 155, no. 4, 214 p., 4 pls., 25 figs.

Dott, R. H., Jr., 1966, Late Jurassic unconformity exposed in southwestern Oregon: Ore Bin, v. 28, no. 5, p. 85-97, 3 figs.

1971, Geology of the southwestern Oregon coast west of the 124th meridian: Oregon Dept. Geology and Mineral Industries Bull. 69. 63 p., 2 pls., 36 figs.

Duffield, W. A., and Sharp, R. V., 1975, Geology of the Sierra Foothills melange and adjacent areas, Amador County, California: U.S. Geol. Survey Prof. Paper 827, 30 p., 1 pl., 7 figs.

Eardley, A. J., 1933, Stratigraphy of the southern Wasatch Mountains, Utah: Michigan Acad. Sci. Papers, v. 18, p. 307-344, 4 pls., 2 figs.

Ekren, E. B., and Houser, F. N., 1965, Geology and petrology of the Ute Mountains area, Colorado: U.S. Geol. Survey Prof. Paper 481, 74 p., 1 pl., 26 figs.

Emergy, K. O., and Uchupi, Elazar, 1972, Western North Atlantic Ocean-topography, rocks, structure, water, life, and sediments: Am. Assoc. Petroleum Geologists Mem. 17, 532 p., 330 figs., 1 map.

Enay, Raymond, 1964, L'étage Tithonique, in Colloque du Jurassique (Luxembourg, 1962), Luxembourg, Inst. Grand-ducal, Sec. Sci. Nat., Phys., Math., p. 355-379, 6 figs.

1971, Les zones du Jurassique en France-Tithonique-Portlandien (sens français): Soc. Géol. France Compte Rendu, no. 2, p. 98-100.

__ 1972, Paleobiogéographie des ammonites du Jurassique terminal (Tithonique/Volgien/Portlandien, l.s.) et mobilite continentale: Geobios, v. 5, pt. 4, p. 355-407, 13 figs., correlation chart.

Enay, Raymond, Tintant, Henri, and Rioult, Michel, 1971, Les zones du Jurassique en France-Kimmeridgien (sens français): Soc. Geol. France Compte Rendu, no. 2, p. 97-98.

Engel, R. L. H., 1959, Geology of the Lake Elsinore quadrangle, California: California Div. Mines Bull. 146, p. 9-58, pls. 1-3, 7 figs.

Erben, H. K., 1954, Dos amonitas nuevos y su importancia para la estratigrafia del Jurásico inferior de México: México Univ. Nac., Inst. Geología Paleontolgía Mexicana, no. 1, 23 p., 1 pl.

1956a, El Jurasico Inferior de Mexico y sus amonitas: Mexico, D. F., Internat. Geol. Cong., 20th, 1956, 393 p., 41 pls., 5 maps. 1956b, El Jurásico Medio y el Calloviano de Mexico: Mexico D. F., Internat., Geol Cong., 20th, 1956, 140 p., 19 pls.

1957a, New biostratigraphic correlations in the Jurassic of eastern and south-central Mexico, in El Mesozoico del Hemisferio Occidental y sus correlaciones mundiales: Internat. Geol. Cong., 20th, Mexico, D. F., 1956 [Trabajos], sec. 2, p. 43-52.

1957b, Paleographic reconstructions for the Lower and Middle Jurassic and for the Callovian of Mexico in El Mesozoico del Hemisferio Occidental y sus correlaciones mundiales: Internat. Geol. Cong., 20th, Mexico, D. F., 1956 [Trabajos], sec. 2, p. 35-41, 2 figs.

Eric, J. H., Stromquist, A. A., and Swinney, C. M., 1955, Geology and mineral deposits of the Angels Camp and Sonora quadrangles, Ca- laveras and Tuolumne Counties, Califormia: California Div. Mines Spec. Rept. 41, 55 p., illus.

Flores Lopez, Roberto, 1967, La fauna Líasica de Mazatepec, Puebla, in Estratigrafia del Jurásico de Mazatepec, Puebla (México): Inst. Mexicano Petróleo Tecnología Explor. Secc. Geologia Mon. 1, Pub 7A-11, p. $25-30$

Forgotson, J. M., Jr., 1954, Regional stratigraphic analysis of the Cotton Valley group of Upper Gulf Coastal Plain: Am. Assoc. Petroleum Geologists Bull., v. 38, no. 12, p. 2476-2499.

Foster, H. L., 1947, Paleozoic and Mesozoic stratigraphy of northern Gros Ventre Mountains and Mount Leidy Highlands, Teton County, Wyoming: Am. Assoc. Petroleum Geologists, v. 31, p. 1537-1593, 9 figs.

Francis, D. R., 1956, Jurassic stratigraphy of the Williston Basin area: Saskatchewan Dept. Mineral Resources 18, 69 p., 17 pls., 4 figs.

Frebold, Hans, 1951a, Ammonite fauna and stratigraphy of the Lower Lias in Tyaughton Lake map-area, British Columbia: Canada Geol. Survey Bull. 18, p. 1-14, pls. 1-14 in part, 2 figs.

1951b, Lowermost Middle Jurassic fauna in Whitesail Lake maparea, British Columbia: Canada Geol. Survey Bull. 18, p. 18-21, pl. 15.

1953, Correlation of the Jurassic formations of Canada: Geol. Soc. America Bull., v. 64, p. 1229-1246.

1954, Stratigraphic and palaeogeographic studies in the Jurassic Fernie group: Alberta Soc. Petroleum Geologists News Bull., v. 2, p. $1,2$.

1957, The Jurassic Fernie group in the Canadian Rocky Mountains and foothills: Canada Geol. Survey Mem. 287, 197 p., 44 pls., 5 figs.

1958, Fauna, age and correlation of the Jurassic rocks of Prince Patrick Island: Canada Geol. Survey Bull. 41, p. 1-29, pls. 1-18, 2 figs.

1959, Marine Jurassic rocks in Nelson and Salmo areas, southern British Columbia: Canada Geol. Survey Bull. 49, 31 p.

1960, The Jurassic faunas of the Canadian Arctic-Lower Jurassic and lowermost Middle Jurassic ammonites: Canada Geol. Survey Bull. 59, 33 p., pls. 1-15, 8 text figs.

1961, The Jurassic faunas of the Canadian Arctic-Middle and Upper Jurassic ammonites: Canada Geol. Survey Bull. 74, 43 p., pls. 1-21, 3 text figs.

1963, Ammonite faunas of the Upper Middle Jurassic beds of the Fernie group in western Canada: Canada Geol. Survey Bull. 93, 33 p., 14 pls., 1 fig.

1964a, Illustrations of Canadian fossils-Jurassic of western and Arctic Canada: Canada Geol. Survey Paper 53-4, 106 p., 51 pls. 1964b, Outline of the Jurassic system in Canada, in Colloque du Jurassique (Luxembourg, 1962): Luxembourg, Inst. Grand-ducal, Sec. Sci. Nat., Phys., Math., p. 479-483.

1964c, The Jurassic faunas of the Canadian Arctic-Cadoceratinae: Canada Geol. Survey Bull. 119, 27 p., 20 pls., 1 fig.

1964d, Lower Jurassic and Bajocian ammonoid faunas of northwestern British Columbia and southern Yukon: Canada Geol. Survey Bull. 116, 31 p., 8 pls., 1 fig.

1966, Upper Pliensbachian beds in the Fernie Group of Alberta: Canada Geol. Survey Paper 66-27., 8 p.

1967a, Position of the Lower Jurassic genus Fanninoceras McLearn and the age of the Maude Formation on Queen Charlotte Islands: Canadian Jour. Earth Sci., v. 4, p. 1145-1149, pl. 1.

1967b, Hettangian ammonite faunas of the Taseko Lakes area, British Columbia: Canada Geol. Survey Bull. 158, 35 p., 9 pls., 6 figs.

1969, Subdivision and facies of Lower Jurassic rocks in the southern Canadian Rocky Mountains and foothills: Geological Assoc. Canada Proc., v. 20, p. 76-87, 2 pls., 1 fig. 
1975, The Jurassic faunas of the Canadian Arctic-lower Jurassic ammonites, biostratigraphy and correlations: Canada Geol. Survey Bull. 243, 34 p., 5 pls., 2 figs.

Frebold, Hans, Mountjoy, E. W., and Reed, R. A., 1959, The Oxfordian beds of the Jurassic Fernie group, Alberta and British Columbia: Canada Geol. Survey Bull. 53, 47 p., 12 pls., 6 figs.

Frebold, Hans, Mountjoy, E. W., and Tempelman-Kluit, D. J., 1967, New occurrences of Jurassic rocks and fossils in central and northern Yukon Territory: Canada Geol. Survey Paper 67-12, 35 p., 3 pls., 2 figs.

Frebold, Hans, and Tipper, H. W., 1967, Middle Callovian sedimentary rocks and guide ammonites from southwestern British Columbia: Canada Geol. Survey Paper 67-21, 29 p., 3 pls., 2 figs.

1970, Status of the Jurassic in the Canadian Cordillera of British Columbia, Alberta, and southern Yukon: Canadian Jour. Earth Sci., v. 7, no. 1, p. 1-21, 9 figs.

1973, Upper Bajocian-Lower Bathonian ammonite fauna and stratigraphy of Smithers area, British Columbia: Canadian Jour. Earth Sci., v. 10, no. 7, p. 1109-1131, 8 pls., 3 figs.

1975, Upper Callovian and lower Oxfordian ammonites from southeastern Bowser Basin, British Columbia: Canadian Jour. Earth Sci., v. 12, no. 2, p. 145-157, 2 pls., 2 figs.

Frebold, Hans, Tipper, H. W., and Coates, J. A., 1969, Toarcian and Bajocian rocks and guide ammonites from southwestern British Columbia: Canada Geol. Survey Paper 67-10, 54 p., 6 pls., 4 figs.

Gabilly, Jean, Contini, Daniel, Mouterde, Rene, and Rioult, Michel, 1971, Les zones du Jurassique en France-Bajocien: Soc. Geol. France Compte Rendu, no. 2, p. 85-88.

Gardner, L. S., 1944, Phosphate deposits of the Teton Basin area, Idaho and Wyoming: U.S. Geol. Survey Bull. 944-A, 36 p.

Gardner, L. S., Hendricks, T. A., Hadley, H. D., and Rogers, C. P., Jr., 1945, Columnar sections of Mesozoic and Paleozoic rocks in the mountains of south-central Montana: U.S. Geol. Survey Oil and Gas Inv. Prelim. Chart 18.

Gerasimov, P. A., and Mikhailov, N. P., 1967, Volgian stage and universal stratigraphic scale of the Upper Jurassic, in Upper Jurassic stratigraphy: International Symposium in the U.S.S.R., Moscow, June 6-18, 1967, Program and guidebooks, p. 4-24.

Gerth, Enrique, 1925, La fauna neocomiana de la Cordillera Argentina en la parte meridional de la Provincia de Mendoza: Acad. Nac. Cienc. Argentina Actas, v. 9, p. 57-132, 6 pls.

Gilluly, James, 1929, Geology and oil and gas prospects of part of the San Rafael swell, Utah: U.S. Geol. Survey Bull. 806-C, p. 69130 , pls. $30-35$, fig. 10 .

Gilluly, James, and Reeside, J. B., Jr., 1928, Sedimentary rocks of the San Rafael Swell and some adjacent areas in eastern Utah: U.S. Geol. Survey Prof. Paper 150, p. 61-110, pls. 16-21, fig. 2.

Gordon, W. A., 1974, Physical controls on marine biotic distribution in the Jurassic period in Paleogeographic provinces and provinciality: Soc. Econ. Paleontologists and Mineralogists Spec. Pub. 21, p. 136-147, 5 figs.

Gott, G. B., and Schnabel, R. W., 1963, Geology of the Edgemont NE quadrangle, Fall River and Custer counties, South Dakota: U.S. Geol. Survey Bull. 1063-E, p. E127-E188, pls. 12-16, figs. $22-38$.

Granger, A. E., 1953, Stratigraphy of the Wasatch Range near Salt Lake City, Utah: U.S. Geol. Survey Cir. 296, p. 1-14.

Grantz, Arthur, '1960, Geologic map of Talkeetna Mountains (A-1) quadrangle, and the south third of Talkeetna (B-1) quadrangle, Alaska: U.S. Geol. Survey Misc. Geol. Inv. Map I-314.

1961, Geologic map and cross sections of the Anchorage (D-2) quadrangle and northeasternmost part of the Anchorage (D-3) quadrangle, Alaska: U.S. Geol. Survey Misc. Geol. Inv. Map. I342.
Grantz, Arthur, Thomas, Herman, Stern, T. W., and Sheffey, N. B., 1963 , Potassium-argon and lead-alpha ages for stratigraphically bracketed plutonic rocks in the Talkeetna Mountains, Alaska: U.S. Geol. Survey Prof. Paper 475-B, p. B56-B59.

Gregory, H. E., 1950, Geology and geography of the Zion Park region, Utah and Arizona: U.S. Geol. Survey Prof. Paper 220, 200 p., 5 pls., 133 figs.

Guillaume, Louis, 1928, Revision des posidonomyes Jurassiques: Soc. Geol. France Bull., v. 27, p. 217-234, pl. 10.

Guzman, Jimenez, E. J., 1950, Geologia del Noreste de Guerrero: Asoc. Mexicana Geologos Petroleros Bol., v. 2, no. 2, p. 95-156.

Hadley, H. D., Gardner, L. S., and Rogers, C. P., Jr., 1945, Graphic sections of Mesozoic and Paleozoic rocks that underlie the basin areas in south-central Montana: U.S. Geol. Survey Oil and Gas Inv. Prelim. Chart 19.

Halbouty, M. T., 1966, Stratigraphic-trap possibilities in Upper Jurassic rocks, San Marcos arch, Texas: Am. Assoc. Petroleum Geologists Bull., v. 50, p. 3-24.

Hallam, Anthony, 1965, Observations on marine Lower Jurassic stratigraphy of North America, with special reference to United States: Am. Assoc. Petroleum Geologists Bull., v. 49, p. 1485-1501, 5 figs.

Hansen, W. R., 1965, Geology of the Flaming Gorge area, Utah-Colorado-Wyoming: U.S. Geol. Survey Prof. Paper 490, 196 p., 3 pls., 68 figs.

Hardy, C. T., 1952, Eastern Sevier Valley, Sevier and Sanpete counties, Utah, with reference to formations of Jurassic age: Utah Geol. Mineralog. Survey Bull. 43, 98 p., 9 pls., 4 figs.

1962, Mesozoic and Cenozoic stratigraphy of north-central Utah, in Geology of the southern Wasatch Mountains and vicinity, Utah: Brigham Young Univ. Geology Studies, v. 9, pt. 1, p. 50-64.

Hardy, C. T., and Zeller, H. D., 1953, Geology of the west-central part of the Gunnison Plateau, Utah: Geol. Soc. America Bull. v. 64, p. 1261-1278, 3 pls., 3 figs.

Harshbarger, J. W., Repenning, C. A., and Irwin, J. H., 1957, Stratigraphy of the uppermost Triassic and the Jurassic rocks of the Navajo country: U.S. Geol. Survey Prof. Paper 291, 74 p., 3 pls., 38 figs.

Hartman, J. A., 1968, The Norphlet sandstone, Pelahatchie Field, Rankin County, Mississippi: Gulf Coast Assoc. Geol. Socs. Trans., v. 18, p. $2-11$.

Hatten, C. W., 1967, Principal features of Cuban geology [discussion of paper by K. N. Khudoley, 1967]: Am. Assoc. Petroleum Geologists Bull., v. 51, p. 780-789.

Hazzard, R. T., 1939, Notes on the Comanche and Pre-Comanche(?) Mesozoic formations of the Ark-La-Tex area, and a suggested correlation with northern Mexico: Shreveport Geol. Soc. Guidebook 14th Ann. Field Trip, p. 155-165.

Hazzard, R. T., Spooner, W. C., and Blanpied, B. W., 1947, Notes on the stratigraphy of the formations which underlie the Smackover limestone in south Arkansas, northeast Texas and north Louisiana: Shreveport Geol. Soc. 1945 Ref. Report., v. 2, p. 483-503.

Hearn, B. C., Jr., Pecora, W. T., and Swadley, W C, 1964, Geology of the Rattlesnake quadrangle, Bearpaw Mountains, Blaine County, Montana: U.S. Geol. Survey Bull. 1181-B, p. B1-B66 [1965].

Herrera, N. M., 1961, Contribución a la estratigrafía de la Provincia de Pinar del Río: Soci. Cubana Ingenieros, v. 61, nos. 1 and 2, p. 1 24,13 photos, 8 text figs, 1 fold-in pl.

Heyl, G. R., and Eric, J. H., 1948, Newton copper mine, Amador County, California: California Div. Mines Bull. 144, p. 49-60.

Hillebrandt, Axel von, 1970, Zur Biostratigraphie und AmmonitenFauna des sudamerikanischen Jura (Insbes. Chile): Neues Jahrb. Geologie u. Paläontologie Abh., v. 136, pt. 2, p. 166-211, 3 figs. 1973, Neue Ergebnisse uber der Jura in Chile and Argentina: 
Münster Forsch. Geologie u. Paläontologie, v. 31, p. 167-199, 4 figs.

Hollister, C. D., and others, 1972, Site 105-Lower Continental Rise Hills, in Initial Reports of the Deep Sea Drilling Project, v. XI Washington, U.S. Govt. Printing Office, p. 219-312, 6 figs.

Hose, R. K., 1955, Geology of the Crazy Woman Creek area, Johnson County, Wyoming: U.S. Geol. Survey Bull. 1027-B, p. 33-118, pls. 6-13, figs. 13-27.

Housa, V., and La Nuez, M. L. de, 1975, Ammonite fauna of the Tithonian and lowermost Cretaceous of Cuba [Abs.]: France Bur. Recherches Geol. et Minières Mem. 86, p. 57.

Howarth, M. K., 1958, A monograph of the ammonites of the Liassic family Amaltheidae in Britain: London, Palaeontographical Soc. pt. 1, I-XIV, 1-26, pls. 1-4; pt. 2, p. XV-XXXVII, 27-53, pls. $5-10$.

Huddle, J. W., and McCann, F. T., 1947, Pre-Tertiary geology of the Duchesne River area, Wasatch and Duchesne Counties, Utah: U.S. Geol. Survey Oil and Gas Inv. Prelim. Map 75.

Humphrey, W. E., 1956, Tectonic framework of northeast Mexico: Gulf Coast Assoc. Geol. Socs. Trans., v. 6, p. 25-35.

Hyatt, Alpheus, 1892, Jura and Trias at Taylorsville, California: Geol. Soc. America Bull., v. 3, p. 395-412.

Imlay, R. W., 1939, Jurassic ammonites from Mexico: Geol. Soc. America Bull., v. 50, p. $1-78,18$ pls., 7 figs.

1940a, Upper Jurassic pelecypods from Mexico: Jour. Paleontology, v. 14 , no. 5, p. 393-411, pls. 50-56, 1 fig.

1940b, Lower Cretaceous and Jurassic formations of southern Arkansas and their oil and gas possibilities: Arkansas Geol. Survey Inf. Circ. 12, 64 p., 26 pls.

-1942, Late Jurassic fossils from Cuba and their economic significance: Geol. Soc. America Bull., v. 53, p. 1417-1478, 12 pls., 4 figs.

1943a, Jurassic formations of Gulf region: Am. Assoc. Petroleum Geologists Bull., v. 27, no. 11, p. 1407-1533, 14 figs.

-1943b, Upper Jurassic ammonites from the Placer de Guadalupe district, Chihuahua, Mexico: Jour. Paleontology, v. 17, no. 5, p. 527-543, pls. 87-95.

1945, Jurassic fossils from the Southern States, No. 2: Jour. Paleontology, v. 19, no. 3, p. 253-276, pls. 39-41, 1 fig.

1947, Marine Jurassic of Black Hills area, South Dakota and Wyoming: Am. Assoc. Petroleum Geologists Bull., v. 31, p. 227-273, 3 figs.

1948, Characteristic marine Jurassic fossils from the western interiol of the United States: U.S. Geol. Survey Prof. Paper 214B, p. 13-33, pls. 5-9.

1950, Jurassic rocks in the mountains along the west side of the Green River Basin: Wyoming Geol. Assoc., Guidebook, 5th Ann. Field Conf., Aug. 1950, p. $37-48$.

-1952a, Correlation of the Jurassic formations of North America exclusive of Canada: Geol. Soc. America Bull., v. 63, no. 9, p. 953-992, 2 correlation charts.

1952b, Marine origin of Preuss Sandstone of Idaho, Wyoming, and Utah: Am. Assoe. Petroleum Geologists Bull., v. 36, no. 9, p. 1735-1753, 4 figs.

- 1952c, Summary of Jurassic history in the western interior of the United States: Billings Geol. Soc., Guidebook, 3d Ann. Field Conf., Sept. 1952, p. 79-85, chart.

1953a, Callovian (Jurassic) ammonites from the United States and Alaska. Part 1, Western interior United States: U.S. Geol. Survey Prof. Paper 249-A, p. 1-40, pls. 1-24, 2 figs.

1953b, Callovian (Jurassic) ammonites from the United States and Alaska. Part 2, Alaska Peninsula and Cook Inlet regions: U.S. Geol. Survey Prof. Paper 249-B, p. 41-108, pls. 25-55, figs. 3-9. 1953c, Las formaciones jurasicas de Mexico: Soc. Geol. Mexicana Bol., v. 16, no. 1, p. 1-65.

1953d, Characteristics of the Jurassic Twin Creek limestone in Idaho, Wyoming and Utah: Intermountain Assoc. Petroleum Geologists, 4th Ann. Field Conf., 1953, p. 54-62.

1954, Marine Jurassic formations in the Pryor Mountains and north Bighorn Mountains, Montana: Billings Geol. Soc. Guidebook 5th Ann. Field Conf., 1954, p. 54-64, 2 figs.

1955, Characteristic Jurassic mollusks from northern Alaska: U.S. Geol. Survey Prof. Paper 274-D, p. 69-96, pls. 8-13, fig. 20.

1956a, Marine Jurassic exposed in Bighorn Basin, Pryor Mountains, and northern Bighorn Mountains, Wyoming and Montana: Am. Assoc. Petroleum Geologists, v. 40, no. 4, p. 562-599, 7 figs. $1956 \mathrm{~b}$, Interpretations of the marine Jurassic fossil record at Lower Slide Lake, Teton County, Wyoming: Wyoming Geol. Assoc., Guidebook, 11th Ann. Field Conf., 1956, p. 70-71.

1957, Paleoecology of Jurassic seas in the Western Interior of the United States: Geol. Soc. America Mem. 67, p. 469-504, 8 text figs.

1959a, History of Jurassic sedimentation in the Pacific Coast region-Logdell to Pine Creek, Field Trip no. 6, in Wilkinson, W. D., ed., Field guidebook, June 1959: Oregon Dept. Geology and Mineral Industries Bull. 50, p. 103-108.

1959b, Succession and speciation of the pelecypod Aucella: U.S. Geol. Survey Prof. Paper 314-G, p. 155-169, pls. 16-19.

1960, Ammonites of Early Cretaceous age (Valanginian and Hauterivian) from the Pacific Coast States: U.S. Geol. Survey Prof. Paper 334-F, p. 167-228, pls. 24-43, figs. 34-36, 1 correlation chart.

1961, Late Jurassic ammonites from the western Sierra Nevada, California: U.S. Geol. Survey Prof. Paper 374-D, 30 p., 6 pls.

1962a, Late Bajocian ammonites from the Cook Inlet region, Alaska: U.S. Geol. Survey Prof. Paper 418-A, p. 1-15, pls. 15,4 figs.

1962b, Jurassic (Bathonian or Early Callovian) ammonites from Alaska and Montana: U.S. Geol. Survey Prof. Paper 374-C, p. C1-C32, 8 pls., 7 figs.

1963, Jurassic fossils from southern California: Jour. Paleontology, v. 37 , no. 1 , p. $97-107$, pl. 14 .

1964a, Upper Jurassic mollusks from eastern Oregon and western Idaho. U.S. Geol. Survey Prof. Paper 483-D, p. 1-21, 4 pls. 1964b, Middle Bajocian ammonites from the Cook Inlet region, Alaska: U.S. Geol. Survey Prof. Paper 418-B, p. 1-61, pls. 129, 5 figs.

1964c, Middle and Upper Jurassic fossils from southern California: Jour. Paleontology, v. 38, no. 3, p. 505-509, pl. 78.

1964d, Marine Jurassic pelecypods from central and southern Utah: U.S. Geol. Survey Prof. Paper 483-C, p. C1-C42, 4 pls., 1 fig.

1965, Jurassic marine faunal differentiation in North America: Jour. Paleontology, v. 39, no. 5, p. 1023-1038, 6 text figs.

1967a, The Mesozoic pelecypods Otapiria Marwick and Lupherella Imlay, new genus, in the United States: U.S. Geol. Survey Prof. Paper 573-B, p. B1-B10, 2 pls.

$-1967 \mathrm{~b}$, Twin Creek Limestone (Jurassie) in the western interior of the United States: U.S. Geol. Survey Prof. Paper 540, 105 p., 16 pls. 18 figs.

1968, Lower Jurassic (Pliensbachian and Toarcian) ammonites from eastern Oregon and California: U.S. Geol. Survey Prof. Paper 593-C, p. C1-C51, 9 pls., 8 figs.

1971, Jurassic ammonite succession in the United States, in Colloque du Jurassique (Luxembourg, 1967): France Bur. Recherches Geol. et Minieres Mem., no. 75, p. 709-724, 1 fig. [1973]. 
1973, Middle Jurassic (Bajocian) ammonites from eastern Oregon: U.S. Geol. Survey Prof. Paper 756, 100 p., 48 pls., 8 figs.

1975, Stratigraphic distribution and zonation of Jurassic (Callovian) ammonites in southern Alaska: U.S. Geol. Survey Prof. Paper 836, 28 p., 6 pls., 9 text figs.

Imlay, R. W., Cepeda, Edmundo, Alvarez, Manuel, Jr., and Diaz- Gonzalez, T. E., 1948, Stratigraphic relations of certain Jurassic formations in eastern Mexico: Am. Assoc. Petroleum Geologists Bull., v. 32 , no. 9, p. 1750-1761, 1 fig.

Imlay, R. W., and Detterman, R. L., 1973, Jurassic paleobiogeography of Alaska: U.S. Geol. Survey Prof. Paper 801, 34 p., 15 figs.

Imlay, R. W., Dole, H. M., Wells, F. G., and Peck, Dallas, 1959, Relations of certain Jurassic and Lower Cretaceous formations in southwestern Oregon: Am. Assoc. Petroleum Geologists Bull., v. 43 , no. 12 , p. $2770-2785$, 3 figs.

Imlay, R. W., Gardner, L. S., Rogers, C. P., Jr., and Hadley, H. D., 1948, Marine Jurassic formations of Montana: U.S. Geol. Survey Oil and Gas Inv. Prelim. Chart 32.

Imlay, R. W., and Jones, D. L., 1970, Ammonites from the Buchia zones in northwestern California and southwestern Oregon: U.S. Geol. Survey Prof. Paper 647-B, 59 p., 15 pls., 8 figs.

Irwin, W. P., 1960, Geologic reconnaissance of the northern Coast Ranges and Klamath Mountains, California: California Div. Mines Bull. 179, 80 p., 1 pl., 16 figs., 15 photos.

-1966, Geology of the Klamath Mountains province in Geology of northern California: California Div. Mines and Geology Bull. 190, p. $19-38$.

Jansa, L. F., 1974, Stratigraphy and sedimentology of the Mesozoic and Tertiary rocks of the Atlantic Shelf: Canada Geol. Survey, $\mathrm{Pa}-$ per 74-1, p. B, p. 141-143.

Jaworski, Erich, 1929, Eine Liasfauna aus Nordwest-Mexico: Schweizer. Palaeont. Gesell. Abh., v. 48, 12 p., 1 pl.

-1940, Oxford-Ammoniten von Cuba: Neues Jahrb., Beilage-B. 83 , pt. B, no. 1 , p. $87-137$, pls. $3-7$.

Jeannet, Alphonse, 1951, Stratigraphie und Paläontologie des oolithischen Eisenerzlagers von Hernznach und seiner Umgebung: Beitr. Geologie Schweiz, Geotech. ser., v. 5, lief. 13, 240 p., 107 pls.

Jeletzky, J. A., 1950, Stratigraphy of the west coast of Vancouver Island between Kyuquot Sound and Esperanza Inlet, British Columbia: Canada Geol. Survey Paper 50-37, 52 p., geol. map., correlation chart.

1953, Tertiary rocks of the Hesquiat-Nootka area, west coast of Vancouver Island, British Columbia: Canada Geol. Survey Paper 53-17, 65 p., map,

-1965, Late Upper Jurassic and early Lower Cretaceous fossil zones of the Canadian western Cordillera, British Columbia: Canada Geol. Survey Bull. 103, 70 p., 22 pls., 4 figs.

1966, Upper Volgian (Latest Jurassic) ammonites and buchias of Arctic Canada: Canada Geol. Survey Bull. 128, 51 p., 8 pls.

1970 , Some salient features of early Mesozoic history of insular tectonic belt, western British Columbia: Canada Geol. Survey Paper $69-14,26$ p., 2 figs.

Jeletzky, J. A., and Tipper, H. W., 1968, Upper Jurassic and Cretaceous rocks of Taseko Lakes map-area and their bearing on the geological history of southwestern British Columbia: Canada Geol. Survey Paper 67-54, 218 p., 14 figs.

Jones, D. L., 1975, Discovery of Buchia rugosa of Kimmeridgian age from the base of the Great Valley sequence: Geol. Soc. America Abs. with Programs, v. 7, no. 3, p. 330.

Jones, D. L., Bailey, E. H., and Imlay, R. W., 1969, Structural and stratigraphic significance of the Buchia zones in the Colyear Springs-Paskenta area, California: U.S. Geol. Survey Prof. Paper 647-A, p. A1-A24, 5 pls., 5 figs.

Jones, D. L., and Moore, J. G., 1973, Lower Jurassic ammonite from the south-central Sierra Nevada, California: U.S. Geol. Survey Jour. Research, v. 1 , no. 4 , p. $453-458$.
Judoley, C. M., and Furrazola-Bermudez, Gustavo, 1965, Estratigrafia del Jurásico Superior de Cuba: Cuba Inst. Recursos Minerales Dept. Cient. Geologia Pub. Espec. 3, 31 p.

1968, Estratigrafía y fauna del Jurásico de Cuba: Havana, Cuba Inst. Recursos Minerales, Dept. Cient. Geología, 126 p., 81 pls., 41 figs.

Jux, Ulrich, 1951, The Palynologic age of diapiric and bedded salt in the Gulf Coastal Province: Louisiana Geol. Survey Bull. 38, 46 p.

Kauffman, E. G., 1973, Cretaceous Bivalvia, in Hallam, Anthony, ed., Atlas of palaeobiogeography: New York, Elsevier Sci. Pub. Co., p. $353-383,8$ figs.

Khudoley, K. M., and Meyerhoff, A. A., 1971, Paleogeography and geological history of Greater Antilles: Geol. Soc. America Mem. 129,200 p., 30 text figs.

King, R. E., 1939, Geological reconnaissance in northern Sierra Madre Occidental of Mexico: Geol. Soc. America Bull., v. 50, p. 16251722, 9 pls., 7 figs.

Kinney, D. M., 1955, Geology of the Uinta River-Brush Creek area, Duchesne and Uintah Counties, Utah: U.S. Geol. Survey Bull. 1007,187 p., 6 pls., 13 figs.

Kinney, D. M., and Rominger, J. F., 1947, Geology of the Whiterocks River-Ashley Creek area, Uintah County, Utah: U.S. Geol. Survey Oil and Gas Inv. Prelim. Map 82.

Kirkland, D. W., and Gerhard, J. W., 1971, Jurassic salt, central Gulf of Mexico, and its temporal relation to circum-Gulf evaporites: Am. Assoc. Petroleum Geologists Bull., v. 55, no. 5, p. 680-686.

Koch, J. G., 1966, Late Mesozoic stratigraphy and tectonic history, Port Orford-Gold Beach area, south-western Oregon coast: Am. Assoc. Petroleum Geologists Bull., v. 50, p. 25-71, 22 figs.

Krömmelbein, Karl, 1956, Die ersten Marinen fossilien (Trigoniidae, Lamellibr.) aus der Cayetano Formation West-Cubas: Senckenbergiana Lethaea; v. 37, p. 331-335, 1 pl.

Kutek, Jan, Pszczolkowski, Andrzej, and Wierzbowski, Andrzej, 1976, The Francisco Formation and an Oxfordian ammonite faunule from the Artemsia Formation, Sierra del Rosario, western Cuba: Acta Geol. Polonica, v. 26, no. 2, p. 299-319, 2 pls., 9 figs.

Larsen, E. S., Jr., 1948, Batholith and associated rocks of Corona, Elsinore, and San Luis Rey quadrangles, southern California: Geol. Soc. America Mem. 29, 182 p.

Leanza, A. F., 1945, Ammonites del jurasico superior y del cretaceo inferior de la Sierra Azul, en la parte meridional de la Provincia de Mendoza: La Plata Univ. Nac. Mus. Anales new ser., Paleontologia, sec. A, no. 1,99 p., 23 pls.

Lewis, G. E., Irwin, J. H., and Wilson, R. F., 1961, Age of the Glen Canyon group (Triassic and Jurassic) on the Colorado Plateau: Geol. Soc. America Bull., v. 72, no. 9, p. 1437-1440.

Lindgren, Waldemar, 1900, Description of the Colfax quadrangle [California]: U.S. Geol. Survey Geol. Atlas, Folio 66, 10 p.

Lindgren, Waldemar, and Turner, H. W., 1894, Description of the Placerville quadrangle [California]: U.S. Geol. Survey Geol. Atlas, Folio 3, 3 p.

Livingston, D. C., 1932, A major overthrust in western Idaho and northeastern Oregon: Northwest Sei., v. 6, no. 2, p. 31-36.

Loeblich, A. R., Jr., and Tappan, H. N., 1950a, The type Redwater Shale (Oxfordian) of South Dakota, pt. 1 of North American Jurassic Foraminifera: Jour. Paleontology, v. 24, p. 39-60, pls. 1116.

$1950 \mathrm{~b}$, Characteristic western interior Callovian species, pt. 2 of North American Jurassic Foraminifera: Washington Acad. Sei. Jour., v. 40 , p. 5-19, pl. 1.

Lopez Ramos, E., 1972, Estudio del Basamento Igneo y metamorfico de las zonas norte y Poza Rica (entre Nautla, Ver., y Jimenez, Tamps): Asoc. Mexicana de Geologos Petroleros Bol., v. 24, p. 267-323, unnumbered index and structural maps, cross sections and tables. 
1974, Geologia general y de Mexico, 3d ed: Mexico, D. F., Secretaria de Educacion Publica no. 91407, 509 p., 155 figs., 18 tables. Love, J. D., 1939, Geology along the southern margin of the Absaroka Range, Wyoming: Geol. Soc. America Spec. Paper 20, 134 p.

Love, J. D., Denson, N. M., and Botinelly, Theodore, 1949, Geology of the Glendo area, Wyoming: U.S. Geol. Survey Oil and Gas Inv. Prelim. Map 92.

Love, J. D., Duncan, D. C., Bergquist, H. R., and Hose, R. K., 1948, Stratigraphic sections of Jurassic and Cretaceous rocks in the Jackson Hole area, northwestern Wyoming: Wyoming Geol. Survey Bull. 40, 48 p., 2 figs.

Love, J. D., and others, 1945, Stratigraphic sections and thickness maps of Jurassic rocks in central Wyoming: U.S. Geol. Survey Oil and Gas Inv. Prelim. Chart 14.

Love, J. D., Reed, J. C., Jr., Christiansen, R. L., and Stacy, J. R., 1973 , Geologic block diagram and tectonic history of the Teton region, Wyoming-Idaho: U.S. Geol. Survey Misc. Geol. Inv. Map I730.

Love, J. D., Tourtelot, H. A., Johnson, C. O., Thompson, R. M., Sharkey, H. H. R., and Zapp, A. D., 1947, Stratigraphic sections of Mesozoic rocks in central Wyoming: Wyoming Geol. Survey Bull. $38,59 \mathrm{p}$.

Lowry, W. D., 1968, Geology of the Ironside Mountain quadrangle, Baker and Malheur Counties, Oregon: Oregon Dept. Geology and Mineral Industries open-file report.

Lupher, R. L., 1941, Jurassic stratigraphy of central Oregon: Geol. Soc. America Bull., v. 52, no. 2, p. 219-270, 4 pls, 3 figs.

Lupher, R. L., and Packard, E. L., 1930, The Jurassic and Cretaceous rudistids of central Oregon: Oregon Univ. Pub., Geol. Ser., v. 1, no. 3, p. 203-312.

Luterbacher, Hanspeter, 1972, Foraminifera from the lower Cretaceous and upper Jurassic of the northwestern Atlantic: Initial repts., Deep Sea Drilling Proj.: Washington, U.S. Govt. Printing Office, v. 11, p. 561-576, 8 pls., 6 figs.

McGooky, D. P., and others, 1972, Cretaceous System, in Geologic atlas of the Rocky Mountain region: Denver, Rocky Mtn. Assoc. Geologists, p. 190-220.

McIver, N. L., 1972, Cenozoic and Mesozoic stratigraphy of the Nova Scotia Shelf: Canadian Jour. Earth Sci., v. 9, p. 54-70, 5 figs.

McKee, E. D., and MacLachlan, M. E., 1959, Stratigraphic problems of the Wingate sandstone, Moenave formation, and related units, in McKee, E. D., and others, Paleotectonic maps of the Triassic System: U.S. Geol. Survey Misc. Geol. Inv. Map I-300, p. 22, pl. 8, figs. $4-6$.

McKee, E. D., and others, 1956, Paleotectonic maps of the Jurassic system: U.S., Geol. Survey Misc. Geol. Inv. Map I-175, 6 p.

MacKevett, E. M., Jr., 1969, Three newly named Jurassic formations in the McCarthy $\mathrm{C}-5$ quadrangle, Alaska, in Changes in stratigraphic nomenclature by the U.S. Geological Survey, 1967: U.S. Geol. Survey Bull. 1274-A, p. A35-A49, figs. 3-8.

-1971, Stratigraphy and general geology of the McCarthy C-5 quadrangle, Alaska: U.S. Geol. Survey Bull. 1323, 35 p., 3 figs.

McKnight, E. T., 1940, Geology of area between Green and Colorado Rivers, Grand and San Juan Counties, Utah: U.S. Geol. Survey Bull. 908,147 p., 13 pls., 3 figs.

McLearn, F. H., 1929, Contributions to the stratigraphy and paleontology of Skidegate Inlet, Queen Charlotte Islands, British Columbia: Canada Natl. Mus. Bull., 54, Geol. ser., no. 49, p. 1-27, 16 pls.

- 1932, Contributions to the stratigraphy and paleontology of Skidegate Inlet, Queen Charlotte Islands, British Columbia: Royal Soc. Canada Proc. and Trans., 3d ser., v. 26, sec. 4, p. 51-84, pls. 1-10

1949, Jurassic formations of Maude Island and Alliford Bay, Skidegate Inlet, Queen Charlotte Islands, British Columbia: Canada Geol. Survey Bull. 12, p. 1-19, 3 figs.
McMath, V. E., 1966, Geology of the Taylorsville area, northern Sierra Nevada, in Geology of northern California: California Div. Mines and Geology Bull. 190, p. 173-183.

Maher, J. C., and Applin, E. R., 1968, Correlation of subsurface Mesozoic and Cenozoic rocks along the eastern Gulf Coast: Am. Assoc. Petroleum Geologists, Cross Section Pub. 6, p. 1-29, 6 pls., 1 text fig.

Mansfield, G. R., 1927, Geography, geology, and mineral resources of part of southeastern Idaho, with descriptions of Carboniferous and Triassic fossils by G. H. Girty: U.S. Geol. Survey Prof. Paper 152, 453 p., 70 pls., 46 figs.

1952, Geography, geology, and mineral resources of the Ammon and Paradise Valley quadrangles, Idaho: U.S. Geol. Survey Prof. Paper 238, 92 p., 2 pls., 27 figs.

Mansfield, G. R., and Roundy, P. V., 1916, Revision of Beckwith and Bear River formations of southeastern Idaho: U.S. Geol. Survey Prof. Paper 98, p. 75-84.

Mapel, W. J., 1959, Geology and coal resources of the Buffalo- Lake De Smet area, Johnson and Sheridan Counties, Wyoming: U.S. Geol. Survey Bull. 1078, 148 p., 23 pls., 6 figs.

Mapel, W. J., and Bergendahl, M. H., 1956, Gypsum Spring formation, northwestern Black Hills, Wyoming and South Dakota: Am. Assoc. Petroleum Geologists Bull., v. 40, p. 84-93.

Mapel, W. J., and Pillmore, C. L., 1963, Geology of the Newcastle area, Weston County, Wyoming: U.S. Geol. Survey Bull. 1141$\mathrm{N}$, p. N1-N85, 3 pls., 11 figs.

Martinez Perez, Jesus, 1972, Exploracion geologica del area El Estribo-San Francisco, S. L. P. (Hojas K-8 y K-9): Asoc. Mexicana de Geologos Petroleros Bol., v. 24, p. 327-402, geol. map and cross sections.

Mattick, R. E., Foote, R. Q., Weaver, N. L., and Grim, M. S., 1974, Structural framework of United States Atlantic outer continental shelf north of Cape Hatteras: Am. Assoc. Petroleum Geologists Bull., v. 58, no. 6, pt. 2, p. 1179-1190, 10 figs.

Meyerhoff, A. A., 1964, Review of "The geological formations of Cuba" [Bermudez, 1961]: Internat. Geology Rev., v. 6, no. 1, p. 149-156, correlation chart.

Meyerhoff, A. A., and Hatten, C. W., 1968, Diapiric structures in central Cuba: Am. Assoc. Petroleum Geologists Mem. 8, p. 315-357. 1974, Bahamas salient of North America: Tectonic framework, stratigraphy, and petroleum potential: Am. Assoc. Petroleum Geologists Bull., v. 58, no. 6, pt. 2, p. 1201-1239, 14 figs.

Milner, R. L., and Blakslee, G. W., 1958, Notes on the Jurassic of southwestern Saskatchewan, in Goodman, A. J., ed., Jurassic and Carboniferous of western Canada: Am. Assoc. Petroleum Geologists, John Andrew Allan Memorial Volume, p. 65-84, 16 figs.

Milner, R. L., and Thomas, G. E., 1954, Jurassic system in Saskatchewan, in Clark, L. M., ed., Western Canada sedimentary basina symposium: Am. Assoc. Petroleum Geologists, Ralph Leslie Rutherford Memorial Volume, p. 250-267.

Minard, J. P., Perry, W. J., Weed, E. G. A., Rhodehamel, E. C., Robbins, E. I., and Mixon, R. B., 1974, Preliminary report on geology along Atlantic continental margin of northeastern United States: Am. Assoc. Petroleum Geologists Bull., v. 58, no. 6, pt. 2, p. 1169-1178, 7 figs.

Minch, J. A., 1969, A depositional contact between the pre-batholithic Jurassic and Cretaceous rocks in Baja California, Mexico [abs.]: Geol. Soc. America Abs. with Programs 1969 [v.1], pt. 3, p. 4243.

Mirsky, Arthur, 1962, Stratigraphy of non-marine Upper Jurassic and Lower Cretaceous rocks, southern Big Horn Mountains, Wyoming: Am. Assoc. Petroleum Geologists Bull., v. 46, p. 16531680,15 figs.

Misch, Peter, 1966, Tectonic evolution of the Northern Cascades of Washington State-a west-cordilleran case history, in A symposium on the tectonic history and mineral deposits of the western 
Cordillera, Vancouver, B. C., 1964: Canadian Inst. Mining and Metallurgy Spec. Vol. 8, p. 101-148, geol. map.

Mitchell, J. G., 1956, Charophytes as a guide to distinguishing between Lower Cretaceous and Upper Jurassic continental sediments in the subsurface: Intermountain Assoc. Petroleum Geologists, Guidebook, 7th Ann. Field Conf., 1956, p. 105-112.

Mixon, R. B., 1963, Geology of the Huizachal redbeds, Ciudad Victoria area, southwestern Tamaulipas, in Geology of Peregrina Canyon and Sierra del Abra, Mexico: Corpus Christi Geol. Soc., Ann. Field Trip 1963, p. 24-35, 5 text figs.

Mixon, R. B., Murray, G. E., and Diaz-Gonzalez, T. E., 1959, Age and correlation of Huizachal group (Mesozoic), state of Tamaulipas, Mexico: Am. Assoc. Petroleum Geologists Bull., v. 43, no. 4, p. 757-771, 11 text figs.

Moritz, C. A., 1951, Triassic and Jurassic stratigraphy of southwestern Montana: Am. Assoc. Petroleum Geologists Bull., v. 35, p. 17811814.

Morrison, R. F., 1961, Angular unconformity marks Triassic-Jurassic boundary in Snake River area of northeastern Oregon: Ore Bin;, v. 23 , no. 11 , p. $105-111$.

1964, Upper Jurassic mudstone unit named in the Snake River Canyon, Oregon-Idaho boundary: Northwest Sci., v. 38, no. 3, p. 83-87.

Muller, S. W., and Ferguson, H. G., 1939, Mesozoic stratigraphy of the Hawthorne and Tonopah quadrangles, Nevada: Geol. Soc. America Bull., v. 50, p. 1573-1624, 5 pls., 4 figs.

Murray, G. E., 1961, Geology of the Atlantic and Gulf Coastal province of North America: New York, Harper \& Bros., 692 p.

Myczynski. Ryszard, 1976, A new ammonite fauna from the Oxfordian of the Pinar del Rio province, western Cuba: Acta Geol. Polonica, v. 26, no. 2, p. 262-297, pls. 1-20, 22 figs.

Myczynski, Ryszard, and Pszczolkowski, Andrzej, 1976, The ammonites and age of the San Cayetano Formation from the Sierra del Rosario, western Cuba: Acta Geol. Polonica, v. 26, no. 2, p. 321329,2 pls., 3 figs.

Nordquist, J. W., 1955, Pre-Rierdon Jurassic stratigraphy in northern Montana and Williston Basin: Billings Geol. Soc. Guidebook, 6th Ann. Field Conf., Sept., 1955, p. 96-106, 2 figs.

Ochoterena F., Hector, 1963, Amonitas del Jurasico Medio y del Calloviano de Mexico-pt. 1, Parastrenoceras gen. nov.: Mexico Univ. Nac. Inst. Geologia Paleontologia Mexicana, no. 16, 26 p., illus.

O'Connell, Marjorie, 1920, The Jurassic ammonite fauna of Cuba: Am. Mus. Nat. History Bull., v. 42, art. 16, p. 643-692, pls. 34-38

Olson, W. S., 1974, Structural history and oil potential of offshore area from Cape Hatteras to Bahamas: Am. Assoc. Petroleum Geologists Bull., v. 58, no. 6, pt. 2, p. 1191-1200, 6 figs.

Oxley, M. L., and Minihan, E. D., 1968, Jurassic geology of Alabama and Florida panhandle: Gulf Coast Assoc. Geol. Socs. Trans., v. 18 , p. 51.

Oxley, M. L., Minihan, E. D., and Rigdeway, J. M., 1967, A study of the Jurassic sediments in portions of Mississippi and Alabama: Gulf Coast Assoc. Geol. Socs. Trans., v. 17, p. 24-48, 15 text figs.

Pampeyan, E. H., Schroeder, M. L., Schell, E. M., and Cressman, E. R., 1967, Geologic map of the Driggs quadrangle, Bonneville and Teton Counties, Idaho, and Teton County, Wyoming: U.S. Geol. Survey Mineral Inv. Field Studies Map MF-300, and sections.

Parsons, C. F., 1974, The sauzei and so called sowerbyi zones of the lower Bajocian: Newsletters on Stratigraphy, v. 3, pt. 3, p. 153180,2 pls., 4 figs.

Paterson, D. F., 1968, Jurassic megafossils of Saskatchewan, with a note on charophytes: Saskatchewan Dept. Mineral Resources Rept. 120,80 p., 26 pls., 8 figs.

Peck, R. E., 1956, Rocky Mountain Mesozoic and Cenozoic nonmarine microfossils: Wyoming Geol. Assoc. 11th Ann. Field Conf., 1956, Guidebook, p. 95-98.
Pérez Fernandez, Rául, and Diaz Gonzales, Teodoro, 1964, Jurassic data from wells in northeastern Mexico: Gulf Coast Assoc. Geol. Socs. Trans., v. 14, p. 231-232.

Peterson, Fred, 1973, Geologic map of the southwest quarter of the Gunsight Butte quadrangle, Kane and San Juan counties, Utah, and Coconino County, Arizona: U.S. Geol. Survey Mineral Inv. Field Studies Map MF-306.

1974, Correlation of the Curtis, Summerville, and related units (Upper Jurassic) in south-central Utah and north-central Arizona [abs.]: Geol. Soc. America Abs. with Programs, v. 6, no. 5, p. $466-467$.

Peterson, Fred, and Barnum, B. E., 1973, Geologic map of the southeast quarter of the Cummings Mesa quadrangle, Kane and San Juan counties, Utah, and Coconino County, Arizona: U.S. Geol. Survey Misc. Geol. Inv. Map I-758.

Peterson, Fred, Cornet, Bruce, and Turner-Peterson, C. E., 1977, New data bearing on the stratigraphy and age of the Glen Canyon Group (Triassic and Jurassic) in southern Utah and northern Arizona [abs.]: Geol. Soc. America Abs. with Programs, v. 9, no. 6, p. 755.

Peterson, J. A., 1954a, Marine Upper Jurassic, eastern Wyoming: Am. Assoc. Petroleum Geologists Bull., v. 38, p. 463-507, 10 figs.

1954b, Jurassic Ostracoda from the "lower Sundance" and Rierdon formations, western interior United States: Jour. Paleontology, v. 28 , p. $153-176$, pls. 17-19.

1957, Marine Jurassic of northern Rocky Mountains and Williston Basin: Am. Assoc. Petroleum Geologists Bull., v. 41, no. 3, p. $399-440,18$ figs.

-1972, Jurassic system, in Geologic atlas of the Rocky Mountain region: Denver, Rocky Mtn. Assoc. Geologists, p. 177-189, 12 figs.

Philpott, T. H., and Hazzard, R. T., 1949, Preliminary correlation chart of Upper Gulf Coast, in Shreveport Geological Society Guidebook 17th Ann. Field Trip, Cretaceous of Austin, Texas, area, 1949: chart in pocket.

Phoenix, D. A., 1963, Geology of the Lees Ferry area, Coconino County, Arizona: U.S. Geol. Survey Bull. 1137, 86 p., 3 pls., 14 figs.

Pipiringos, G. N., 1953, Correlation of marine Jurassic and related rocks in the Laramie Basin, Wyoming: Wyoming Geol. Assoc. Guidebook 8th Ann. Field Conf., Laramie Basin, Wyoming, and North Park, Colorado, 1953, p. 34-39.

1957, Stratigraphy of the Sundance, Nugget and Jelm formations in the Laramie Basin, Wyoming: Wyoming Geol. Survey Bull. 47, 63 p., 5 pls., 3 figs.,

1968, Correlation and nomenclature of some Triassic and Jurassic rocks in south-central Wyoming: U.S. Geol. Survey Prof. Paper 594-D, p. D1-D26, 23 figs.

1972, Upper Triassic and pre-Morrison Jurassic rocks, in Segerstrom, Kenneth, and Young, E. J., General geology of the Hahns Peak and Farwell Mountain quadrangles, Routt County, Colorado: U.S. Geol. Survey Bull. 1349, p. 18-29 [1973].

Pipiringos, G. N., Hail, W. J., Jr., and Izett, G. A., 1969, The Chinle (Upper Triassic) and Sundance (Upper Jurassic), Formations in north-central Colorado: U.S. Geol. Survey Bull. 1274-N, p. N1N35, 3 figs.

Pipiringos, G. N., and O'Sullivan, R. B., 1975, Chert pebble unconformity at the top of the Navajo Sandstone in southeastern Utah: Four Corners Geol. Soc. Guidebook, 8th Field Conf., Canyonlands, Sept. 22-25, 1975, p. 149-156, 6 figs.

1978, Principal unconformities in Triassic and Jurassic rocks, Western Interior United States-a preliminary survey: U.S. Geol. Survey Prof. Paper 1035-A, p. A1-A29, 1 pl., 5 figs.

Pocock, S. A. J., 1970, Palynology of the Jurassic sediments of western Canada - pt. 1, Terrestrial species: Paleontographica, ser B., v. 130 , no. $1-6$, p. 12-133. 
Poole, F. G., and Stewart, J. H., 1964, Chinle Formation and Glen Canyon Sandstone in northeastern Utah and northwestern Colorado: U.S. Geol. Survey Prof. Paper 501-D, p. D30-D39, 4 figs. [1965].

Popenoe, W. P., Imlay, R. W., and Murphy, M. A., 1960, Correlation of the Cretaceous formations of the Pacific Coast (United States and northwestern Mexico): Geol. Soc. America Bull., v. 71, p. 1491-1540, correlation chart.

Rainwater, E. H., 1967, Resume of Jurassic to Recent sedimentation history of the Gulf of Mexico Basin: Gulf Coast Assoc. Geol. Soc. Trans., v. 17, p. 179-210.

Ramp, Len, 1969, Dothan? fossils discovered: Ore Bin, v. 31, no. 12, p. 245-246.

Ravn, J. P. J., 1911, On Jurassic and Cretaceous fossils from northeast Greenland: Medd. Grønland, v. 45, p. 433-500, pls. 32-38 [1912].

Rayl, R. L., Stratigraphy of the Nesson, Piper and Rierdon formations of central Montana: Billings Geol. Soc., Guidebook, 7th Ann. Field Conf., 1956, p. $35-45$, figs. 3-7.

Reeside, J. B., Jr., 1919, Some American Jurassic ammonites of the genera Quenstedticeras, Cardioceras, and Amoeboceras, Family Cardioceratidea: U.S. Geol. Survey Prof. Paper 118, 64 p., 24 pls., 1 fig.

1952, Summary of the stratigraphy of the Morrison formation, in Yen, Teng-Chien, Molluscan fauna of the Morrison formation: U.S. Geol. Survey Prof. Paper 233-B, p. 22-26.

Reeside, J. B., Jr., chm., 1957, Correlation of the Triassic formations of North America, exclusive of Canada: Geol. Soc. America Bull., v. 68, p. $1451-1514$

Richards, P. W., 1955, Geology of the Bighorn Canyon-Hardin area, Montana and Wyoming: U.S. Geol. Survey Bull. 1026, 93 p., 7 pls., 7 figs.

Richmond, G. M., 1945, Geology of northwest end of the Wind River Mountains, Sublette County, Wyoming: U.S. Geol. Survey Oil and Gas Inv. Prelim. Map 31.

Richter, D. H., and Jones, D. L., 1973, Structure and stratigraphy of eastern Alaska Range, Alaska, in Arctic geology: Am. Assoc. Petroleum Geologists Mem. 19, p. 408-420, 9 figs.

Rinehart, C. D., Ross, D. C., Huber, N. K., 1959, Paleozoic and Mesozoic fossils in a thick stratigraphic section in the eastern Sierra Nevada. California: Geol. Soc. America Bull., v. 70, p. 941-945.

Roberts, R. J., and others, 1958, Paleozoic rocks of north-central Nevada: Am. Assoc. Petroleum Geologists Bull., v. 42, p. 28132857.

Robinson, C. S., Mapel, W. J., and Bergendahl, M. H., 1964, Stratigraphy and structure of the northern and western flanks of the Black Hills uplift, Wyoming, Montana, and South Dakota: U.S. Geol. Survey Prof. Paper 404, 134 p., 5 pls., 8 figs.

Rosenkrantz, Alfred, 1934, The lower Jurassic rocks of East Greenland, part 1: Medd. Grønland, v. 110, no. 1, 122 p., 13 pls., 56 figs.

Rubey, W. W., 1958, Geology of the Bedford quadrangle, Wyoming: U.S. Geol. Survey Geol. Quad. Map GQ-109.

Rubey, W. W., Oriel, S. S., and Tracy, J. I., Jr., 1975, Geology of the Sage and Kemmerer 15-minute quadrangles, Lincoln County, Wyoming. U.S. Geol. Survey Prof. Paper 855, 18 p., 2 pl., 2 figs.

Ruppel, E. T., 1972, Geology of pre-Tertiary rocks in the northern part of Yellowstone National Park, Wyoming: U.S. Geol. Survey Prof. Paper 729-A, p. A1-A66, 1 pl. 23 figs.

Saks, V. N., Mesezhnikov, M. S., and Shulgina, N. I., 1968 [Volgian stage and position of the boundary between Jurassic and Cretaceous Systems in the Arctic zoogeographic region], in Saks, V. N., ed. [Mesozoic marine faunas of the U.S.S.R. north and far east and their significance]: Akad. Nauk SSSR, Sibirskoe Otdeleniye, Inst. Geologii i Geofiziki Trudy, no. 48, p. 72-79 (in Russian).

Saks, V. N., Ronkina, Z. Z., Shulgina, N. I., Basov, V. A., and Bondarenko, N. M., 1963 [Stratigraphy of the Jurassic and Cretaceous systems of the northern USSR]: Moscow and Leningrad, Akad.
Nauk SSSR, Siberskoe Otdeleniye, Inst. Geologii i Geofiziki, 226 p. (in Russian).

Saks, V. N., and Shulgina, N. I., 1964 [on distinguishing the Berriasian stage in the Cretaceous system]: Geologiya i Geofiziki (Akad. Nauk SSSR, Sibirskoe Otdeleniye), 1964, no. 8, p. 3-14 (in Russian; abs. in English).

1972, [Distribution of the Berriasian stage in the Boreal RealmWestern Europe] in Saks, V. N. ed. [Jurassic-Cretaceous boundary and the Berriasian stage in the Boreal Realm]: Novosibirsk, Akad. Nauk SSSR Sibirskoe Otdeleniye, Inst. Geologii i Geofiziki, p. 94-98 (in Russian; English translation, Jerusalem, 1975, available from Natl. Tech. Inf. Service, Springfield, Va. 22151).

Salas, G. P., 1949, Bosquejo geologico de la cuenca sedimentaria de Oaxaca: Asoc. Mexicana Geologos Petroleros Bol., v. 1, no. 2, p. 79-156.

Sanborn, A. F., 1960, Geology and paleontology of the southwest quarter of the Big Bend quadrangle, Shasta County, California: California Div. Mines Spec. Rept. 63, p. 3-26, 12 figs.

Sanchez Mejorada, S. H., and Lopez Ramos, Ernesto, compilers, 1968. Carta geologica de la Republica Mexicana: México, D.F., Comité de la Carta Geologica de México, scale 1:2,000,000.

Sańchez Roig, Mario, 1920, La fauna Jurásica de Vinales: Cuba, Secretaría de Agr., Bol. Especial, 61 p., 23 pls. 1951, La fauna Jurásica de Viñales: Acad. Cienc. Médicas, Físicas y Naturales Habana Anales, v. 89, pt. 2, p. 46-94, 28 pls.

Sandberg, D. T., 1959, Structure contour map on top of the middle member of the Piper Formation of Middle Jurassic age in the Williston basin and adjacent areas in Montana, North Dakota and South Dakota: U.S. Geol. Survey Oil and Gas Inv. Map. OM-179, with section and text.

Sato, Tadashi, 1962, Études biostratigraphiques des ammonites du Jurassique du Japon: Soc. Géol. France Mém., new ser., v. 41, pt. 1 (Mém 94), 122 p., pls. 1-10.

Schmitt, G. T., 1953, Regional stratigraphic analysis of Middle and Upper marine Jurassic in northern Rocky Mountains-Great Plains: Am. Assoc. Petroleum Geologists Bull., v. 37, no. 2, p. 355-393, 13 figs.

Scholten, Robert, Keenmon, K. A., and Kupsch, W. O., 1955, Geology of the Lima region, southwestern Montana and adjacent Idaho: Geol. Soc. America Bull., v. 66, p. 345-404.

Schroeder, M. L., 1969, Geologic map of the Teton Pass quadrangle, Teton County, Wyoming: U.S. Geol. Survey Geol. Quad. Map GQ-793.

Schuchert, Charles, 1923, Sites and nature of the North American geosynclines: Geol. Soc. America Bull., v. 34, p. 151-229, 17 paleogeographic maps.

Schultz, L. K., and Grover, R. L., 1974, Geology of Georges Bank basin: Am. Assoc. Petroleum Geologists Bull., v. 58, no. 6, pt. 2 , p. 1159-1168, 7 figs.

Scott, K. R., Hayes, W. E., and Fietz, R. P., 1961, Geology of the Eagle Mills Formation: Gulf Coast Assoc. Geol. Socs. Trans., v. 11, p. 1-14.

Sharp, R. V., and Duffield, W. A., 1973, Reinterpretation of the boundary between the Cosumnes and Logtown Ridge Formations, Amador County, California: Geol. Soc. America Bull., v. 84, p. $3969 \_3976,4$ figs.

Shawe, D. R., Simmons, G. C., and Archbold, N. L., 1968, Stratigraphy of Slick Rock district and vicinity, San Miguel and Dolores Counties, Colorado: U.S. Geol. Survey Prof. Paper 576-A, p. A1-A108, 16 pls., 48 figs.

Sherwin, D. F., 1973, Scotian Shelf and Grand Banks, in The future petroleum provinces of Canada-their geology and potential: Canadian Soc. Petroleum Geologists Mem. 1, p. 519-559, 16 figs.

Silberling, N. J., 1959, Pre-Tertiary stratigraphy and Upper Triassic paleontology of the Union District, Shoshone Mountains, Nevada: U.S. Geol. Survey Prof. Paper 322, 67 p. 
Silberling, N. J., and Roberts, R. J., 1962, Pre-Tertiary stratigraphy and structure of northwestern Nevada: Geol. Soc. America Spec. Paper 72, 58 p., 2 pls., 7 figs.

Silberling, N. J., Shoellhamer, J. E., Gray, C. H., Jr., and Imlay, R. W., 1961, Upper Jurassic fossils from Bedford Canyon formation, southern California: Am. Assoc. Petroleum Geologists Bull., v. 45, no. 10 , p. $1746-1748$.

Silberling, N. J., and Wallace, R. E., 1969, Stratigraphy of the Star Peak Group (Triassic) and overlying lower Mesozoic rocks, Humboldt Range, Nevada: U.S. Geol. Survey Prof. Paper 592, 50 p.

Smith, G. O., and Calkins, F. C., 1904, A geological reconnaissance across the Cascade Range near the forty-ninth parallel: U.S. Geol. Survey Bull. 235, 103 p., 4 pls., 1 fig.

Smith, J. P., 1914, The Middle Triassic marine invertebrate faunas of North America: U.S. Geol. Survey Prof. Paper 83, 254 p.

Smith, W. D., and Allen, J. E., 1941, Geology and physiography of the northern Wallowa Mountains, Oregon: Oregon Dept. Geology and Mineral Industries Bull. 12, $64 \mathrm{p}$.

Sohl, N. F., 1965, Marine Jurassic gastropods, central and southern Utah: U.S. Geol. Survey Prof. Paper 503-D, p. D1-D29, 5 pls., 2 figs.

Souther, J. G., 1971, Geology and mineral deposits of Tulsequah maparea, British Columbia: Canada Geol. Survey Mem. 362, 84 p., 19 figs., geologic map and appendix of stratigraphic sections.

Spath, L. F., 1927-1933, Revision of the Jurassic cephalopod fauna of Kachh (Cutch): Palaeontologia Indica, n. s., v. 9, 6 pts., 945 p., 130 pls.

1932, The invertebrate faunas of the Bathonian-Callovian deposits of Jameson Land (East Greenland): Medd. Grønland, v. 87, 158 p., 26 pls., 14 text figs.

1935, The Upper Jurassic invertebrate faunas of Cape Leslie, Milne Land; I. Oxfordian and lower Kimmeridgian: Medd. Grønland, v. 99, no. 2,82 p., 14 pls.

1936. The Upper Jurassic invertebrate fauna of Cape Leslie, Milne Land. II. Upper Kimmeridgian and Portlandian: Medd. Grønland, v. 99, no. 3, 180 p., 50 pls.

-1950, A new Tithonian ammonoid fauna from Kurdistan, northern Iraq: British Mus.(Nat. History) Bull., Geology, v. 1, no. 4, p. 96-137, pls. 6-10.

Spieker, E. M., 1946, Late Mesozoic and early Cenozoic history of central Utah: U.S. Geol. Survey Prof. Paper 205-D, p. 117-161, pls. 18-25, figs. 14-21.

Springer, G. D., MacDonald, W. D., and Crockford, M. B. B., 1966, Jurassic, Chap. 10, of Geological history of western Canada: Calgary, Alberta, Alberta Soc. Petroleum Geologists, p. 137-155, geol. maps.

Staatz, M. H., and Albee, H. F., 1963, Preliminary geologic map of the Garns Mountain SE quadrangle, Bonneville and Teton Counties, Idaho: U.S. Geol. Survey Mineral Inv. Field Studies Map. MF262.

1966, Geology of the Garns Mountain quadrangle, Bonneville, Madison, and Teton Counties, Idaho: U.S. Geol. Survey Bull. 1205,122 p., 2 pls. 16 figs.

Stanley, K. O., 1971, Tectonic and sedimentologic history of Lower Jurassic Sunrise and Dunlap formations, west-central Nevada: Am. Assoc. Petroleum Geologists Bull., v. 55, no. 3, p. 454-477, 14 figs.

Stanley, K. O., Jordan, W. W., and Dott, R. H., Jr., 1971. New hypothesis of early Jurassic paleogeography and sediment dispersal for western United States: Am. Assoc. Petroleum Geologists Bull., v. 55 , no. 1 , p. 10-19. 4 figs.

Stokes, W. L., 1944, Morrison formation and related deposits in and adjacent to the Colorado Plateau: Geol. Soc. America Bull., v. 55, p. 951-992.
1963, Triassic and Jurassic formations of southwestern Utah, in Intermountain Assoc. Petroleum Geologists, Guidebook, 12th Ann. Field Conf. 1963, Geology of southwestern Utah, Salt Lake City, Utah Geol. and Mineralog. Survey, p. 60-64, 1 fig.

Surlyk, F., Callomon, J. H., Bromley, R. G., and Birkelund, Tuve, 1973, Stratigraphy of the Jurassic-lower Cretaceous sediments of Jameson Land and Scoresby Land, east Greenland: Grønland Geol. Undersøgelse Bull. 105, p. 5-76. 8 pls., 37 figs.

Swain, F. M., Jr., 1944, Stratigraphy of Cotton Valley beds of northern Gulf Coastal Plain: Am. Assoc. Petroleum Geologists Bull., v. 28, no. 5 , p. $577-614$.

1949, Upper Jurassic of northeastern Texas: Am. Assoc. Petroleum Geologists Bull., v. 33, no. 7, p. 1206-1250.

1952, Mesozoic Ostracoda, Pt. 2 of Ostracoda from wells in North Carolina: U.S. Geol. Survey Prof. Paper 234-B, p. 59-93.

Swain, F. M., and Brown, P. M., 1972, Lower Cretaceous, Jurassic(?), and Triassic Ostracoda from the Atlantic Coastal region: U.S. Geol. Survey Prof. Paper 795, 72 p., 10 pls., 32 figs.

Swain, F. M., and Peterson, J. A., 1951, Ostracoda from the Upper Jurassic Redwater shale member of the Sundance formation at the type locality in South Dakota: Jour. Paleontology, v. 25, p. 796807 , pls. 113, 114.

-1952 , Ostracodes from the upper part of the Sundance formation of South Dakota, Wyoming and southern Montana: U.S. Geol. Survey Prof. Paper 243-A, p. 1-17, pls. 1, 2.

Taliaferro, N. L., 1942, Geologic history and correlation of the Jurassic of southwestern Oregon and California: Geol. Soc. America Bull., v. 53 , p. $71-112$.

-1943a, Manganese deposits of the Sierra Nevada, their genesis and metamorphism: California Div. Mines Bull. 125, p. 277-332. 1943b, Franciscan-Knoxville problem: Am. Assoc. Petroleum Geologists Bull., v. 27, p. 109-219.

Thomas, H. D., and Krueger, M. L., 1946, Late Paleozoic and early Mesozoic stratigraphy of Uinta Mountains, Utah: Am. Assoc. Petroleum Geologists Bull., v. 30, p. 1255-1293, 10 figs.

Thomas, W. A., and Mann, C. J., 1963, Correlation chart of upper Cotton Valley sands, in Report on selected north Louisiana and south Arkansas oil and gas fields and regional geology-reference volume 5: Shreveport, La., Shreveport Geol. Soc., p. 9-15.

Thompson, A. E., and Stokes, W. L., 1971, Stratigraphy of the San Rafael group, southwest and south central Utah: Utah Geol. and Mineralog. Survey Bull. 87, $31 \mathrm{p}$.

Tipper, H. W., and Richards, T. A., 1976, Jurassic stratigraphy and history of north-central British Columbia: Canada Geol. Survey Bull. 270, 73 p., 33 pls., 17 text-figs.

Torrens, H. S., 1965, Revised zonal scheme for the Bathonian stage of Europe: Carpatho-Balkan Geol. Assoc., 7th Cong., Sofia, 1965, Repts., pt. 2, v. 1, p. 47-55, 2 figs.

Tozer, E. T., 1960, Summary account of Mesozoic and Tertiary stratigraphy, Canadian Arctic Archipelago: Canada Geol. Survey Paper $60-5,24$ p., 5 figs., correlation chart.

Turner, H. W., 1894, Description of the Jackson quadrangle [California]: U.S. Geol. Survey Geol. Atlas, Folio 11, 6 p.

1897, Description of the Downieville quadrangle [California]: U.S. Geol. Survey Geol. Atlas, Folio 37, 8 p., maps.

Turner, H. W., and Ransome, F. L., 1897, Description of the Sonora quadrangle [California]: U.S. Geol. Survey Geol. Atlas, Folio 41, $5 \mathrm{p}$.

Untermann, G. E., and Untermann, B. R., 1954, Geology of Dinosaur National Monument and vicinity, Utah-Colorado: Utah Geol. and Mineralog. Survey Bull. 42, 221 p., 3 pls., 10 figs., 51 photos.

Upshaw, C. G., Armstrong, W. E., Creath, W. B., Kidson, E. J., and Sanderson, G. A., 1974, Biostratigraphic framework of Grand Banks: Am. Assoc. Petroleum Geologists Bull., v. 58, no. 6, pt. 2, p. 1124-1132, 11 figs. 
Vallier, T. L., 1968, Reconnaissance geology of the Snake River Canyon between Granite Creek and Pittsburg Landing, Oregon and Idaho: Ore Bin, v. 30, no. 12, p. 233-252.

Verma, H. M., and Westermann, G. E. G., 1973, The Tithonian (Jurassic) ammonite fauna and stratigraphy of Sierra Catorce, San Luis Potosi, Mexico: Bulls. Am. Paleontology, v. 63, p. 107-278, pls. 22-55, 32 figs.

Vestal, J. H., 1950, Petroleum geology of the Smackover formation of southern Arkansas: Arkansas Resources Devel. Comm., Div. Geology Inf. Circ. 14, $19 \mathrm{p}$.

Viniegra O., Francisco, 1971, Age and evolution of salt basins of southeastern Mexico: Am. Assoc. Petroleum Geologists Bull., v. 55, no. 3, p. 478-494, 10 figs.

Wagner, N. S., Brooks, H. C., and Imlay, R. W., 1963, Marine Jurassic exposures in Juniper Mountain area of eastern Oregon: Am. Assoc. Petroleum Geologists Bull., v. 47, p. 687-691.

Wall, J. R., Murray, G. E., and Diáz-Gonzalez, T. E., 1961, Geologic occurrence of intrusive gypsum and its effect on structural forms in Coahuila marginal folded province of northeastern Mexico: Am. Assoc. Petroleum Geologists Bull., v. 45, no. 9, p. 1504-1522, 14 figs.

Wanless, H. R., Belknap, R. L., and Foster, H. L., 1955, Paleozoic and Mesozoic rocks of the Gros Ventre, Teton, Hoback, and Snake River ranges, Wyoming: Geol. Soc. America Mem. 63, 90 p.

Weaver, Charles, 1931, Paleontology of the Jurassic and Cretaceous of west-central Argentina: Washington Univ. [Seattle] Mem. 1, 469 p., 62 pls.

Weeks, W. B., 1938, South Arkansas stratigraphy with emphasis on the older Coastal Plain beds: Am. Assoc. Petroleum Geologists Bull., v. 22, p. 953-983, 3 figs.

Weeks, W. B., and Alexander, C. W., 1942, Schuler Field, Union County, Arkansas: Am. Assoc. Petroleum Geologists Bull., v. 26, no. 9, p. 1467-1516, 24 figs.

Weidie, A. E., and Wolleben, J. A., 1969, Upper Jurassic stratigraphic relations near Monterrey, Nuevo Leon, Mexico: Am. Assoc. Petroleum Geologists Bull., v. 53, no. 12, p. 2418-2420, 1 fig.

Weir, J. D., 1949, Marine Jurassic formations of southern Alberta plains: Am. Assoc. Petroleum Geologists, v. 33, p. 547-563, 3 figs.

Wells, F. G., Hotz, P. E., and Cater, F. W., Jr., 1949, Preliminary description of the geology of the Kerby quadrangle, Oregon: Oregon Dept. Geology and Mineral Industries Bull. 40.

Wells, F. G., and Walker, G. W., 1953, Geology of the Galice quadrangle, Oregon: U.S. Geol. Survey Geol. Quad. Map GQ-25.

Wells, J. W., 1942, A new species of coral from the Jurassic of Wyoming: American Mus. Nat. History Novitates 1161, p. 1-3.

Westermann, G. E. G., 1964, The ammonite fauna of the Kialagvik Formation at Wide Bay, Alaska Peninsula-part 1, Lower Bajocian (Aalenian): Bulls. Am. Paleontology, v. 47, p. 329-503, pls. 44-76, 37 text figs.

1966, The holotype (plastotype) of ?Titanites occidentalis Frebold from the Kootenay sandstone (Upper Jurassic) of southern British Columbia: Canadian Jour. Earth Sei., v. 3, no. 5, p. 623625 , illus.

1967, Sucesion de ammonitos de Jurasico medio en Antofagasta, Atacama, Mendoza y Neuquen: Rev. Asoc. Geol. Argentina: v. 22, no. 1 , p. 65-73, 3 figs.
1969, The ammonite fauna of the Kialagvik Formation at Wide Bay, Alaska Peninsula-pt. 2, Sonninia sowerbyi zone (Bajocian): Bulls. Am. Paleontology, v. 57, no. 255, 226 p., pls. 1-47, 56 figs.

Wheeler, J. O., 1961, Whitehorse map-area, Yukon Territory, 105D: Canada Geol. Survey Mem. 312, 156 p., 14 pls., 19 figs., geol. map.

Wiedmann, Jost., 1973, Ancyloceratina (ammonoidea) at the Jurassic/ Cretaceous boundary, in Atlas of Paleobiogeography: New York, Elsevier Sci. Pub. Co., p. 309-316, 2 figs.

Wierzbowski, Andrzej, 1976, Oxfordian ammonites of the Pinar del Rio Province (western Cuba); their revision and stratigraphical significance: Acta Geologica Polonica, v. 26, no. 2, p. 138-260, pls. 18,21 figs.

Williams, G. L., 1974, Biostratigraphy and paleoecology of the Mesozoic and Cenozoic rocks of the Atlantic Shelf: Canada Geol. Survey Paper 74-1, pt. B, p. 150-152.

Wilson, I. F., and Rocha, V. S., 1949, Coal deposits of the Santa Clara district, near Tonichi, Sonora, Mexico: U.S. Geol. Survey Bull. 962-A, $80 \mathrm{p}$.

Wilson, R. F., 1965, Triassic and Jurassic strata of southwestern Utah-resources for power: Utah Geol. Soc., Guidebook to Geology of Utah, no. 19 , p. $31-46$, illus.

1967, Whitmore Point, a new member of the Moenave Formation in Utah and Arizona: Plateau, v. 40, no. 1, p. 29-40.

Wright, J. C., and Dickey, D. D., 1958, Pre-Morrison Jurassic strata of southwestern Utah, in Inter-mountain Assoc. Petroleum Geologists, Guidebook, 9th Ann. Field Conf., Geology of southwestern Utah, 1963; p. 172-181, 7 figs.

1963a, Relations of the Navajo and Carmel Formations in southwest Utah and adjoining Arizona: U.S. Geol. Survey Prof. Paper 450-E, p. E63-E67, fig. 197.

-1963b, Block diagram of the San Rafael Group and underlying strata in Utah and part of Colorado: U.S. Geol. Survey Oil and Gas Inv. Chart OC-63.

Wright, J. C., Shawe, D. R., and Lohman, S. W., 1962, Definition of members of Jurassic Entrada Sandstone in east-central Utah and west-central Colorado: Am. Assoc. Petroleum Geologists Bull., v. 46, no 11, p. 2057-2070.

Wright, P., 1973, Marine Jurassic of Wyoming and South Dakota; its paleobiogeography: Michigan Univ., Mus. Paleontology Papers on Paleontology, no. 2, p. 1-49.

Yen, Teng-Chien, 1952, Molluscan fauna of the Morrison formation: U.S. Geol. Survey Prof. Paper 233-B, p. 21-51.

Zeiss, Arnold, 1956, Hecticoceras und Reineckeia im Mittel- und OberCallovian von Blumberg (Sudbaden): Bayerische Akad. Wiss. Abh., Math.-Naturwiss. Kl., Neue Folge, no. 80, 101 p., 4 pls. 1968, Untersuchungen zur Paläontologie der cephalopoden des unter-Tithon der südlichen Frankenalb: Bayerische Akad. Wiss. Abh., Math.-Naturwiss. Kl., Neue Folge, no. 132, 190 p., 27 pls., 17 figs.

Zeller, H. D., and Stephens, E. V., 1973, Geologie map and coal resources of the Seep Flat quadrangle, Garfield and Kane Counties, Utah: U.S. Geol. Survey Coal Inv. Map. C-65.

Ziegler, Bernhard, 1956, Creniceras dentatum (Ammonitacea) im Mittel-Malm Südwest-Deutschlands: Neues Jahrb. Geologie u. Paläontologie Monatsh., p. 553-575, 13 figs. 


\section{INDEX}

[Italic page numbers indicate major references]

\section{$\mathbf{A}$}

Page

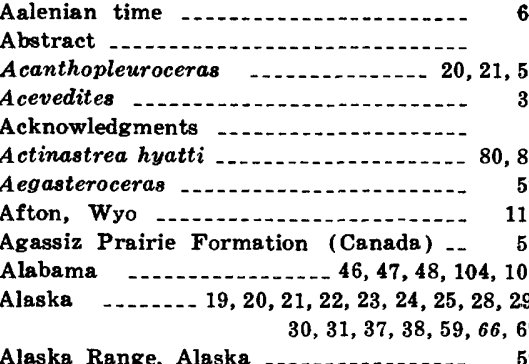

Alaska Range, Alaska -..............- 59 Alaskoceras -

Alberta $18,107,108,113$ Alberta trough, Montana, Canada Alsatites -...................... 19, 20, 55 liasicus zone -1.0 Amaltheus margaritatus -................. 21 zone stokesi

American River, Calif ...... 57, 106

Ammon, Idaho -............... 70

Ammonite sequences, Gulf of Mexico region Ammonite zones, northwest Europe. Se
name of particular zone.

Ammonites, succession of ....... 19, 37, 103 Amoebites (Amoebites), Amoeboceras _... 31, 38, 55, 60 dubium, Amoeboceras _............ 24 Amoeboceras _... 25, 30, 31, 38, 52, 58 alternans (Amoebites) _........... 31, 38, 55, 60 dubium (Prionodoceras) _. spiniferum

Amy Lake, Wash Anahuac, Nuevo Leon Andiceras _..................... 32 Androgynoceras _... 21 Anhydrite Antlers uplift Apoderoceras _.................. 21, 59 Aptian Age Arapien Shale _............ 74, 94 Arctic region, paleobiogeographic setting of Arcticoceras ............ 19, 23, 28, 37, 82, 85 ishmae - 23, 28 Arctoasteroceras _..._. 65 Arctocephalites ......... 19, 23, 28, 37, 59, 81 arcticus _... 23 elegans _... greenlandicus -....... 23 (Cranocephalites) ............... 27

Argenting - 26, 50 Arieticeras $\quad \ldots \ldots \ldots, 21,45,55,56,57,58,65$ Arietites _.................. 20, 21, 52, 55, 58 bucklandi zone

\section{Page}

Arisphinctes $17,96,109,113$

Arizona Arkansas Arkellites hudlestoni zone
Arkelloceras Arnioceras _. 19, 20, 21, 45, 52, 55, 56, 58, 59, 61 semicostatum zone ............. 20 Arniotites _........... 21 Arroyo de San Jose, Baja California --- 51 Arroyo La Mula, Tamaulipas - 33 Artemsia Formation (Cuba) _... 39, 44, 46 Arvison Formation ............... 54,61 Ashman Formation (Canada) ....... 58 Aspidoceras Asterocsras _. obtusum zone .................. 19, 20 Asthenoceras delicatum _........... 56 Ataxioceras Atlantic Coast region _........... 4, 102 Aucella eringtoni ................... 66 Aulacomyella A ulacosphinctes $\ldots \ldots \ldots .24,34,35,36,45,63$ Aulacosphinctoides _............. 24, 32, 57 Aulacostephanoceras acutissiodorensis zone

Aulacostephanus eudoxus zone ........ 24, 50

Aztec Sandstone

Azucar Member, Jagua Formation (Cuba)

- 39,103

\section{B}

Bacon Ridge, Wyo Bagley Andesite .............. 54,61 Baja California, Mexico _.......... 51, 108 Bajocian Stage, Alaska _...... 19, 23, 24, 67 ammonite and buchias succession in - 23,37 arctic region 37 Arizona California $\quad \ldots 17,52,57,60,61,106,107,108$ Canada _........ 18, 25, 67, 102, 106, 109 Cuba _.................. 17, 103, 104 Gulf of Mexico region Idaho _........... 24, 65, 106, 108, 109 Mexico _. 17, 23, 39, 49, 52, 99, 103, 104, 106 Montana _........ 24, 67, 68, 80, 81, 109 Nevada _.......................... 53 North Dakota Oregon _... 17, 18, 23, 64, 65, 106, 107, 108 Pacific Coast region _........ 37, 102, 106 Utah _............. 95, 97, 98, 99, 109 western interior region ....... 18, 24, 67, $102,106,108,111$

Wyoming Baker County, Oreg _... 64, 65 Bald Mountain Formation 66 Balsas Portal (Mexico) Banner, Wyo ... 83, 84 Barklow Mountain, Oreg _.......... 62 Barranca Formation (Mexico) - 52 Basey Member, Snowshoe Formation -. 55
Page

Bathonian Stage, Alaska ......... 19, 28, 37 ammonites and buchias succession

in . ammonites of (........... 28 arctic region Atlantic Coast California -....... 57, 60, 106, 107 Canada Colorado _... Cuba _..................... 17, 103, 104 Gulf of Mexico region -......... 47 Idaho _... Mexico _..................... 17, 25, 37,

$39,49,50,51,52,99,103,104$ Montana _..... 27, 67, 81, 82, 107, 109, 111 North Dakota ............... 67 Oregon _........ 17, 26, 37, 67, 106, 107 Pacific Coast region _............ 102, 107 South Dakota Utah _............. 95, 96, 99, 109, 111 western interior region $. . . .18,27,37,67$

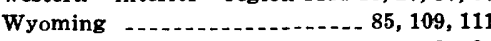
Bearpaw Mountains, Mont ....... 29, 80, 82 Beaverhead County, Mont ............ 81 Becheiceras -.......... 21 (Becheiccras), Liparoceras ........... 20 Bedford Canyon Formation .......... 54, 61 Belt Creek, Mont ........ 68 Belt Island uplift .......... 18, 19,80,81, 113 Berriasella _..................... 24, 34 Berriasian Age _........ 63 Bibliography 114 Big Bend, Idaho _................. 70 Big Bend area, California .... 52, 53, 54, 106 Big Hollow Wash, Utah ........ 77, 98 Big Horn County, Wyo -..... 71 Big Snowy Mountains, Mont $\ldots .69,78,80,82$ Bighorn Basin, Wyo ........... 18, 80, 82 , $83,84,85,86,87,111$

Bighorn Mountains, Wyo., Mont _..... 78, 88, $84,85,86,87$

Billhook Formation (Canada) -..... 58 Black Dragon Canyon, Utah _....... 74, 94 Black Hills, Wyo., S. Dak ...... 83, 85, 86, 87 Blackfoot, Idaho ....... 89, 111 Blackfoot Mountains, Idaho _.......... 89 Blaine County, Mont _............ 80 Bluff Sandstone -.... 96 Bochianites ...... 36

Bolson de Judas, Candela district, Mexioo - 35 Bositra buchii Bossier Formation _........... 44, 47, 105 Boulder, Utah Boundary Ridge Member, Twin Creek Limestone $\quad-1,70,72,74$, $85,88,91,96,99$ Bowes Member, Piper Formation _.. 68, 69, 80 Boyden Cave pendant
Bridger, Mont -........ British Columbia $29,58,59,66,67,68,107,108$ 


\begin{tabular}{|c|c|}
\hline \multicolumn{2}{|c|}{$\begin{array}{l}\text { British Mountains, Yukon Territory } 21,23,29 \\
\text { Brogan, Oreg } \\
\text { Brown Canyon, Utah } \\
\text { Brushy Basin Shale Member, Morrison } \\
\quad \text { Formation }\end{array}$} \\
\hline \multirow{2}{*}{\multicolumn{2}{|c|}{ 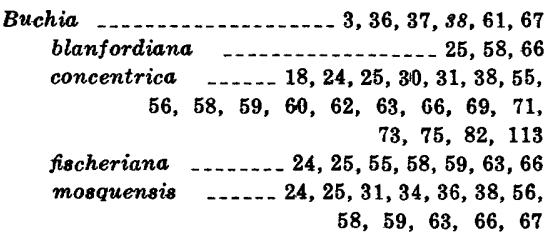 }} \\
\hline & \\
\hline & \\
\hline$i i$ & \\
\hline - & \\
\hline 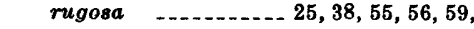 & \\
\hline uloides & \\
\hline & \\
\hline & \\
\hline & \\
\hline & \\
\hline $\begin{array}{l}\text { Utah } \\
\text { on }-42 \text {, }\end{array}$ & \\
\hline$=1$ & \\
\hline & \\
\hline & \\
\hline & \\
\hline
\end{tabular}

C

Caborca, Sonora $23,27,28,29,38,67,88,108$ calyx catostoma …................ 23, 58,59 septentrionale variabile .......................... 23 (Longaeviceras) pomeroyens? _.... 29 (Paracadoceras) _................. 23 tonniense _............ 23 (Stenocadoceras) (............. 23, 29 canadense -. 23 stenoloboide (.............. 23, 59 striatum _.

Cadomites Cahuasas Formation (Mexico) $-45,49,103,104$ California _.... 20, 22, 24, 29, 30,31, 36, 38, 52, $54,55,61,106,107,108$

Callovian Stage, Alaska ............ 19, 29, 38 ammonite and buchia succession in _- 29,38 ammonites of arctic region $\ldots \ldots \ldots \ldots \ldots \ldots, 28,38$ Arizona _........ 113 Atlantic Cosst region -........... 4 California _...... 17, 29, 38, 53, 57, 60, 61, $62,106,107$ Canada $\ldots \ldots \ldots \ldots 29,38,67,107,108,113$

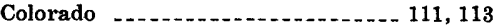
Cubs _. Gulf of Mexico region Idaho _...... 65, 66, 89, 107, 108, 111, 113 Mexico $17,29,38,49,50,51,52,99,103,104$ Montana _......... 29, 67, 81, 111, 113 North Dakota .................. 67 Oregon _.... 17, 38, 60, 64, 65, 66, 106, 107 Pacific Coast region _._._..... 102, 107 South Dakota Utah _............. 95, 99, 102, 111, 113 western interior region ....... 18, 29, 67, $102,107,108,109,111$ Wyoming ........... 89, 111, 113 $\begin{array}{lll}\text { Caloceras } & 19 \\ \text { Camagüey Province, Cuba } & \end{array}$ Campian Age ..... 63 Camptonectes _............ 81, 87, 91, 92, 95
Page

Canada, arctic - $21,22,23$ $25,28,29,30,31,36,37,38$

eastern _............

western _........... 19, 22, 31, 36, 106

Canavaria -....... 20, 65

Cannonville, Utah _........ 77, 98

Cañon Alamo, Sierra Jimulco _........ 36

Cantú Chapa, Abelardo, quoted -...-.- 51

Canyon Springs Sandstone Member,

Sundance Formation -...- 71, 73 $81,84,85,86,88,93,111$

Cape Hatteras, N.C.

Carbon County, Mont 78 Cardioceras _......... 17, 18, 24, 25, 29, 38, 58, $69,71,73,75,82,87,90,92$

canadense _.................. 58 cordatum zone ................ 24, 30,50 cordiforme _........ 24, 30, 69, 71, 73, 75 distans _. martini _.......... 58,59

(Maltoniceras)

(Scarburgiceras) _........... 25, 30 martini _....... 24, 25, 30, 55, 56, 66

(Subvertebriceras) canadense ..... 25 Caribou Range, Idaho -....... 90 Carmel Formation ........ 72, 73, 74, 75, 76, $77,84,87,91,93,95,96,97,99,111$

Cascade Mountains, Wash ........... 56,66 Catacoeloceras _... Catulloceras _.............. 20, 21, 22, 55, 58 Cedar City, Utah . Cedar Mountain, Utah Cerro Pelon, Veracruz

Challenger Knoll _.................. 47

Charcas, San Luis Potosí ........... 49

Charmasseiceras .... 20,21

Chetatites chetae ............. 25

Chetco River, Oreg _............... 63

Chiapas massif, Mexico -........ 51, 106

Chiapas salt basin (Mexico) -...... 51, 106

Chihuahur, Mex:cs - 32, 33, 35, 45, 51, 103, 105 Chinameca, Veracruz _............ 106 Chinitna Formation

Chinle Formation _...... 96,97 Choffatia _... Chondroceras allani Chugwater Formation ............. 83, 84 Cinco Pesos, Cuba Clarke County, Miss

Clarks Fork Canyon, Wyo Climate, Jurassic _- 104, 108, 109, 111, 113, 114 Cloverly Formation ........... 88 Clydoniceras discus zone _............ 22 Coahuila, Mexico _............ 36, 44, 48, 105 Coahuila Peninsula, Mexico _....... 48 Coast Ranges, Calif ............... 53, 61, 63 Cobbanites _....... 22, 23, 26, 27, 28, 37, 55 talkeetnanus Coconino County, Ariz _... 77

Cody, Wyo ...................... 84, 85, 86 Coeloceras Colebrook Schist Colfax, Calif _............ 53, 57 Colorado _...... 73, 85, 90, 93, 96, 109, 113, 114 Colorado Plateau _. 111 Columbus, Mont Combe Formation _... 57 Connor Creek, Oreg ............ 65 Cook Inlet region, Alaska Cooks Canyon Agglomerate ............. 54 Coon Hollow Formation _.......... 56, 66 Copper Hill Volcanics _........... 60 Corongoceras _................ 24, 32, 34, 35, 36 alternans _........... 26, 35 filicostatum ....... 35 Coroniceras _..... 19, 20, 21, 45, 55, 58, 59, 65 bisulcatum
Page

Cosumnes Formation

Cosumnes River, Calif

Cotton Valley Group ............ 44, 47, 48

Cow Creek, Oreg _............. 63

Cow Springs, Ariz

Cow Springs Sandstone _........... 99

Cowley, Wyo _.......... 78

Craig, Mont 68

Cranocephalites

borealis _............. 23 costidensus _............... 23, 58, 59 indistinctus _....... 23 pompeckji _................... 23 vulgaris _...................... 23

(Cranocephalites), Arctocephalites ....- 27

Craspedites canadensis _............. 25

nodiger ..... 27 subditus

Creniceras _... 45, 50 crenatum _................... 30, 50 dentatum _.................... 50 renggeri

Crioceras -............ 36

Crook County, Wyo Crucilobiceras _....... 19, 20, 21, 52, 55, 56,

Cuba $\ldots \ldots 17,24,93,34,99,44,103,104,105$ Cubaochetoceras Cucurpe, Sonora Curry County, Oreg _.......... 62,63 Curtis Formation ....... 74, 75, 89, $92,93,94,9596,113$ Curtis Member, Stump Sandstone .. 72, 73, 89 $90,92,95,113$

\section{D}

Dactylioceras _.......... 20, 21, 22, 58,65 commune _.................. 21, 55, 59 semicelatum tenuicostatum zone

Dalmasiceras

Danish Ranch, Utah

Daonella sanctea-anea

Days Creek, Oreg

Dayville, Oreg _...... 62

Decipia decipiens zone ..................... 24

Deep Creek, Utah

Deerfield basin (Massachusetts) ....... 4

Dennett Creek, Idaho _............ 64, 65

Dewey Bridge, Utah

Dewey Bridge Member, Entrada Sandstone _._.

Diamond Valley, Utah .......... 99 Dichotomosphinctes _..- 24, 25, 30, 52, 55, 59, 60 durangensis _............... 24, 31, 45 muhlbachi _.............. 24 plicatiloides (Dichotomosphinctes), Psrisphinctes -- 30,38,

Dickersonia sabanillensis _................... 35 Dillard, Oreg ......................... 63 Dinosaur Canyon Sandstone Member, Moenave Formation _....... 96 Dinosaur Quarry, Utah _......... 73 Discosphinctes _...... 39, 52, 55, 60 carribeanus _...... 24, 30,45 virgulatiformis _.............. 24

(Discosphinctes), Perisphinctes ....... 30, 38 Divesian (term)

Dixie Creek, Oreg ................. 65

Docidoceras ................. 22, 23, 55, 56, 59 widebayense Dorsetensia -....... 61 oregonensis . 


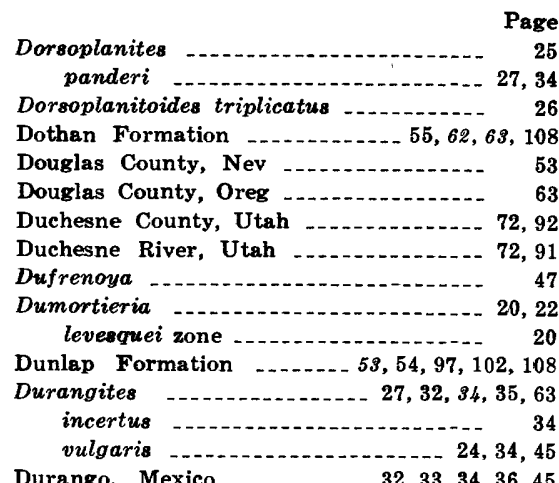

\section{$\mathbf{E}$}

Eagle County, Colo

Eagle Mills Formation ................ 46,47

East Butte, Mont _...... 80

Echioceras _......... 20, 21, 45, 57, 58, 65 arcticum ...... 21 raricostatum zone

Echo Island Formation (Canada) ..... 58

El Antomonio, Sonora

Elk Creek, Colo _.......... 73, 93

Embayment, Gulf of Mexico 104 western interior region

Emery County, Utah _... 74, 75

England, Jurassic formations _..... 44, 54, 90

Enterprise, Oreg _........ 56,65

Entrada Sandstone _........ 72, 73, 74, 75, 77, $92,93,94,95,96,98,99,111,113$

Eocephalites $92,93,94,95,96,98,99,111,113$

Eoderoceras _................. 20,55, 65

Epistrenoceras paracontrarium ............. 22, 25

Epivirgatites nikitini

Erycites -

Erycitoides _... howelli

Erymnoceras coronatum zone ................. 22 mixtecorum $\ldots . . \ldots 22,29,45$

Escalante, Utah _..._. 77, 98

Euaspidoceras _... 24, 30

Eudmetoceras _... 22, 55, 56

Eugeosynclines -

Euhoploceras _....... 55, 57 modesta _................. 22

(Euhoploceras), Sonninia _........ 22

Euprionoceras _................... 25

Europe, northwest, ammonite zones. See name of particular zone.

Europe, southern, subdivisions of the Tithonian in -........ 26

Eurycephalites _.............. 29, 38, 45, 50 boesei -.... 22

Evanston, Wyo

Evaporitic sequences _............... 4,50

Exogyra virgula

\section{F}

Fall River County, S. Dak _...

Fanninoceras _. 20,65

Fant Andesite -...... 54, 57

Faunal relationships, intercontinental .- 37

Fehlmannites _....... 30, 50 Ochetoceras _._._. 50

Fernie, British Columbia _.......... 18

Fernie Group (Canada) -....... 68

Finca Ancon, Pinar del Rio Province, Cuba
Firemoon Limestone Member, Piper Formation _..... 68, 69, 78, 79, 80, 81

Fish Creek, Wyo _... Florida -.... 47 Fontanelliceras _........ 20

Fontannesia _. 22, 56 Foreman Formation Fort Pierce Formation _........ 47 Fossil Mountain, East Greenland ..... 28 Fossils, characteristic -_......... 45, 55, $56,58,59,69,71,73$

Franciscan assemblage _...... 55, 62, 63, 108 Francisco Formation (Cuba) _....... 39,44 Franconites vimineus _...... 26 Frantz Creek, Colo _............. 73, 93 (Franziceras), Psiloceras _.......... 19 Fremont County, Wyo Front Range, Colo Fuciniceras ..................... 20, 56,65

\section{G}

Galeana, Nuevo Leon -...... 35 Galice Formation Gallatin County, Mont Gallatin Range, Mont _............ 80, 81 Garantiana garantiana zone Garfield County, Utah _... 77 Geologic history, Jurassic ........... 102 Gervillia montanaensis Giraffe Creek Member, Twin Creek Limestone _.. 70, 72, 74, 88, 94, 108 Glacier National Park, Mont ......... 80, 113 Glaucolithites ..... 25 gorei zone ..................... 24, 26 Glen Canyon Sandstone ...... 72, 73, 91, 109 Glendale, Utah Gleviceras plauchuti -.... 21 Glochiceras fialar _................. 24, 30, 31, 45 lithographicum - 26 Gold-belt area, Sierra Nevada, Calif -.- 54 Goliathiceras _.... 25, 87 Gopher Ridge Volcanics Gcre Range, Colo Gowericeras costidensus subitum _................... 29 Gracilisphinctes progracilis zone -...- 22 Grammatodon -.... 84 Grammoceras thouarsense zone 20 Grand Banks, Newfoundland _._. 4, 103 Grand County, Colo Grand County, Utah _........ 75 Grand Junction, Colo _........... 96 Grapevine Creek, Mont Graphoceras concavum zone _....... 22, 57 Gravelbourg Formation (Canada) -- 69, 78, 80 Gravesia Grayiceras mexicanum $\quad 35$ Graylock Formation Great Falls, Mont . Green River, Utah _....... Green River Lakes, Wyo _....... 70, 85, 86, 88 Greenland, East .... 19, 21, 22, 23, 25, 28, 82, 85 Gregoryceras transversarium zone -.. 24,50 Gros Ventre River, Wyo _.......... 83, 88 Grossouvria Gryphaea culebra 56 impressimarginata _. 22, 28, 69, 71, 73, 75 nebrascensis _...... 22, 69, 71, 73, 75, 88 planoconvexa _._. $69,71,73,75,80,81,89$ Guasasa Formation (Cuba) _....... 39, 44 Guerrero, Mexico _... 17, 23, 25, 45, 51, 52, 102, 103,104
Guerrero embayment (Mexico) $-\begin{array}{r}\text { Page } \\ \text {-...-. 17, 20, }\end{array}$ $25,29,52,103$

Guhsania bella 23 Gulf of Mexico, Jurassic connections with Pacific and Atlantic Oceans _._. Gulf of Mexico region, ammonite succession and correlation in .. 24, 38

characteristic fossils of ........... 45 geologic history of

Jurassic formations in ........ 44

lithologic and stratigraphic features of

locality bibliographic references -.- 3

paleobiogeographic setting -...-.- 4

Tithonian Stage in ........... 32, 34

United States, stratigraphic and lithologic comparisons in .- 46

unconformities in -..... 99 Gunlock, Utah Gunnison, Utah Gunnison Plateau, Utah ............. 74, 94 Gyphaea planoconvexa -........... 22 planoconvexa fraterna Gypsum _..._. 67, 79, 83, 87, 95, 104, 109, 111 Gypsum Creek, Mont _............. 78, 84 Gypsum Spring Formation $71,78,82,84,88,89,90,95,99,109$ Gypsum Spring Member, Twin Creek Limestone -........ 18, 70, $72,74,82,83,90,91,94$

Gyrochorte

\section{$\mathbf{H}$}

Hagermeister Island, Alaska _........ 19 Hahns Peak, Colo Hanna, Utah . Haploceras Hardgrave Sandstone _... Hardin trough, Wyoming ......... 19

Harpoceras exaratum _.............. 20, 21, 22, 58

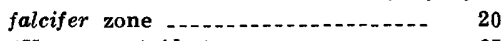
(Harpoceratoides) (Harpoceratoides), Harpoceras ....... 65 Harris Wash Tongue, Page Sandstone - 77 Harrison Lake, British Columbia .... 58, 67 Harrison Lake Formation (Canada) -.. 58 Hartford basin (Connecticut) ....... 4 Hartville uplift Hatteras Abyssal Plain ........... 4, 103 Haugia _....... 20, 21, 22, 55, 59 variabilis zone Haynesville Formation _............ 46 Heath, Mont . 69 Hecticoceras _... retrocostatum zone _............ 22

Hells Backbone, Utah _............ 98 Hettangian Stage, Alaska ammonites and buchias succession in Arizona in Mexico _... 19, 52, 99 Nevada $\ldots \ldots \ldots \ldots, 53,106$ Oregon Pacific Coast region -........... 102 Utah Hibbard Creek, Oreg _... 65 Hidalgo, Mexico Hildaites Hildoceras bifrons zone ............ 20 Hildoglochiceras ecarinatum Himalayites ....................... 36 Hinchman Sandstone _.......... 54, 60, 107 Hoback Range, Wyo Hoplocardioceras .... 


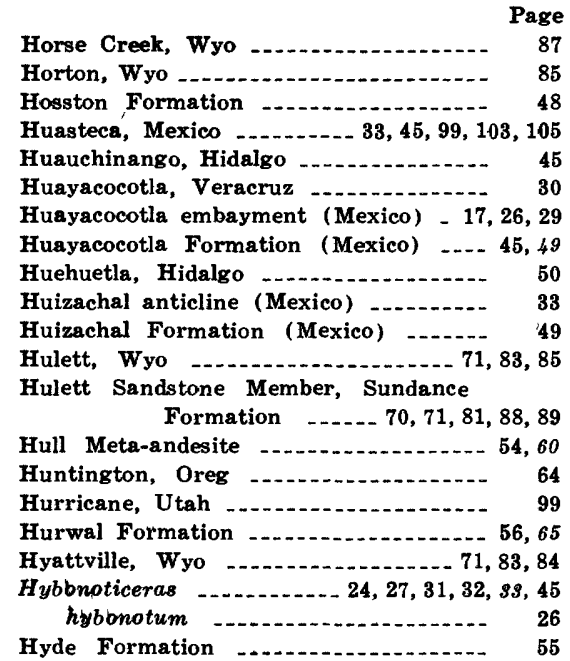

I

Idaho _.... 17, $24,30,52,63,7 \mathrm{C}, 80,82,83,89$, $90,92,106,107,108,109,111,113$

Idaho Falls, Idaho

Idoceras _....... 24, 30, 31, 32, 38, 45, 52, 55

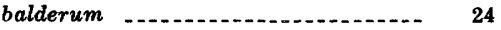
durangense

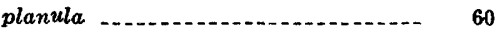

(Ilowaiskya) pseudosycthica, Subplanitee 27

(Ilowaiskya) sokolovi, Subplanites _.... 27

Imlayoceras miettense

Indian Creek, Mont

Iniskinites _.............. 23, 29, 64 intermedius _............... 22

Inkin Formation (Canada)

Inoceramus

Interior region. See Western interior region.

Introduction

Iron County, Utah

Iron Mountain Creek, Oreg - 63

Ironside, Oreg _... 56

Islands, Jurassic $\ldots \ldots 18,52,102,106,109,111$ Isthmus of Tehuantepec Izee, Oreg $\ldots \ldots \ldots 55,64,65,66,102,106,107$

\section{$\mathbf{J}$}

Jackson, Wyo _....... $70,83,84,88$ Jackson Hole, Wyo _........... 90 Jagua Formation (Cuba) _... $\$ 9,42,44,48,50$ Jagua Vieja Member, Jagua Formation (Cuba) - 39

Japan -... John Brown Creek valley, Colorado -.- 75, 96 John Day, Oreg ................. 21, 26, 63, 65 Johnson Canyon, Utah _...... 97, 98 Johnson County, Wyo ............. 71 Jonotla, Puebla _.................... 35 Josephine ultramafic mass .......... 62 Juab County, Utah ................... 74 Juarez, Durango _........ 45 Judd Hollow Tongue, Carmel Formation 77, 98 Judith River, Mont .................. 68 Junction Creek Sandstone _........ 75, 96 Juniper Mountain, Oreg _.......... 64,65

\section{$\mathbf{K}$}

Kachpurites fulgens 27 Kanarraville, Utah Kane County, Utah
Kayenta Formation _- 74, 75, 76, 77, 96, 97, 109 Kellawaysites _................... 22 (Kellawaysites), Reineckia -........ 50 Keller Creek Shale _............... 55, 64 Kent Formation (Canada) -......... 58 Kepplerites -........ 22, 23, 27, 28, 29, 37, 38 ,

$45,50,55,56,58,59,82$ costidensus $\quad \ldots \ldots \ldots 22,28,69,71,73,75,82$ maclearni _..... 22, 28, 69, 71, 73, 75, 82 Bnugharborense _................ 65 Bubitus torrensi _... tychonis

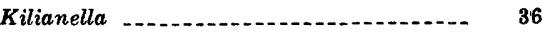
Kimmeridge Clay (England) Kimmeridgian Stage, Alaska .......... 31, 38 ammonite and buchia succession in - $\$ 0,38$ Atlantic Coast region -......... 103 California $17,31,38,60,61,63,106,107,108$ Canada _................... 18, 31, 38, 67 Colorado Cuba - 39,42 definition of ......... 30 England -.......... 31 Gulf of Mexico region _........ 17, 38, 48, 102, 104, 105 Mexisiana Mexico $-\ldots .30,38,49,51,52,102,103,106$
Michigan $-\ldots . .99$ Montana _........ 18, 67, 82, 99, 113, 114 North Dakota _.... 67, 99 Oregon _........... 17, 38, 62, 106, 107 Pacific Coast region ............. 102, 108 South Dakota _.......... 90, 99 Texas _... Utah

Washington western interior region

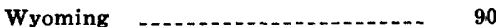
Kings River, Calif . Klamath Mountains, Calif., Oreg - 17, 53, 61, 62 Kline Member, Nesson Formation ... 69, 78 Knoxville Formation _... 55, 62, 63, 66, 107, 108 Kootenai Formation _............. 67, 68 Kosmoceras _... jason zone ..................... 22

Kossmatia _... 24, 27, 32, 33, $34,35,36,51,55$ lingi rancheriasensis ........... 35 varicostata _............... 35 victoris Kossmatia-Durangites ammonite assemblage

Kremmling, Colo _....... 93 Kunga Formation (Canada)

Kuskokwim, Alaska

\section{L}

La Boca Formation (Mexico) -..... 49 La Caja Formation (Mexico) $\ldots . . .45,48,105$ La Casita Formation (Mexico) _..... 34, 44, $45,48,105$ La Gloria Formation (Mexico) $\ldots 45,48,49,50$ La Joya Formation (Mexico) $\ldots 44,45,49,104$ La Punta de San Hipolito, Baja Califor-

$$
\text { nia }
$$

Laberge Group (Canada) Lak Member, Sundance Formation .... 71, 73, $85,86,88,93,111,113$

Lake Fork, Utah _........... 72, 91, 92 Lake Pillsbury, Calif _... 63 (Lamberticeras) collieri, Quensted-

$$
\text { toceras - }
$$

Lander, Wyo $\ldots$ Las Villas Province, Cuba _.......... 34 Latiwitchellia ........ 58 gracilis
(Latiwitchellia), Witchellia Page Laugeites vogulicus _.............. 25 Leeds Creek Member, Twin Creek Limestone _..._. 70, 72, 74, 88, 94, 111 Leioceras opalinum -........... 23, 24, 25 opalinum zone _.......... 22, 23, 24, 37 Leptaleoceras _..._...... 20, 21, 55, 58,65 Leptosphinctes $\quad-\ldots 22,23,37,45,55,56,59,107$ Levan, Utah _...... 74, 94 Lewistown, Mont Liberty County, Mont _....... 80 Lilac Argillite Lilloettia _... 28, 29, 38, 50, 64, 66, 82 buckmani _..... 22, 23, 27, 55, 56, 58, 59, 65 stantoni … Lingula _........................ 113

Lioceratoides _............. 65

Liparoceras (Becheiceras) _......... 20

Lithologic and stratigraphic features,

comparisons of ......... s $s$

Little Bull Valley, Utah _......... 77, 98 Little Rocky Mountains, Mont _. 29, 81, 82, 113 Little Sheep Mountain, Wyo _......... 87 Little Water Canyon, Mont _......... 81 Locality data, bibliographic references to 3 Lodge Grass Creek, Mont -......... 78, 84 Log town Ridge Formation -- 54, 60, 61, 62, 107 Loma Rinconada, Sierra Cruillas ..... 35 Loma Sabinilla, Las Villas, Cuba ..... 34 Lonesome Formation ................. 55, 66 Longaeviceras _...................... 23 (Longaeviceras) pomeroyense, Cadoceras 29 Lopha - - . - . . . Louann Salt_ 17, 44, 46, 47, 48, 49, 50, 51, 99, 102 Louisiana _................ 31, 46, 47, 48 Lovell, Wyo _..................... 87 Lower Slide Lake, Wyo ........ 70, 84, 85, 88 Lubbe Creek Formation ........... 59 Lucky S Argillite ................... 54 Ludwigia murchisonae zone ............ 22 Lukachukai Member, Wingate Sandstone $\quad 97$ Lupherites - ...... 37 Lyosoma powelli _.................... 84, 89 (Lyroxyites), Oppelia _............. 23 Lytoceras Lytohoplites caribbeanus

\section{$\mathbf{M}$}

MeCarthy Formation _........ 59 McCoy Creek, Idaho McDonell Lake, British Columbia ...... 58 McElmo Canyon, Colo Macrocephalites _........ 29, 38, 50, 55, 61, 67 macrocephalus zone ............ 22, 28, 82 Madera County, Calif _....... 57 Madison County, Mont Madison Range, Mont ............ 81 Malheur County, Oreg _......... 64, 65 Malone Formation _... 45, 51 Malone Mountains, Tex ......... 31, 35, 45 (Maltoniceras) Cardiocera $a_{8}$ Manila, Utah _... 92 Manitoba _.

Marias Pass, Mont Marine transgressions $-\ldots 17,18,46,47,48,51$, $80,85,102,103,104,105,109,113$ Mariposa Formation 54,60,61, 62, 102, 107, 108 Masefield Shale (Canada) _........ 69 Maude Formation (Canada) _........ 58 Maude Island, British Columbia -....- 66 Mazapil, Zacatecas ............... 32, 33 Mazapilites $\ldots . . . . . .24,27,32, s s, 40,42,45$ Mazatepec, Puebla _...... 35 Megarietites _........... 20,55, 56, 65 
Page

Megasphaeroceras $22,23,24,37$, $58,59,69,71,73,75,80,81$ rotundum _.................... 22, 23 Meleagrinella curta _........... 94, 95 Merced River, Calif ............... 60 Mesa County, Colo Metahaplocenas -............. 24, 31, 34, 35 (Metapeltoceras), Peltoceras …....... 22, 55 Metophioceras -....................... 65 Mexico _... 17, 19, 20, 22, 23, 24, 25, 27, 29, 30, $31,32,34,35,36,38,44,45,48$, $49,51,103,105,106$

Mexico, Gulf of. See Gulf of Mexico.

Michigan basin 99

Michoacan, Mexico -

Micracanthoceras -........... 24, 32, 34, 35, 36 acanthellum - 35

Microderoceras _......................- 59

Midcontinent region (United States) -. 99

Miles City, Mont _....... 69

Mill Creek, Wyo .................... 84

Miller Creek, Colo -

Minas Viejas Formation (Mexico) .... 44, 48

$50,99,104$

Mineral, Idaho ................. 56, 64, 65 Minnekahta, S. Dak -

Miogeosyncline -..................... 53

Mirosphinctes _..................... $\quad 39$

Mississippi -

Mosb, Utah _........... 96

Moab Member, Entrada Sandstone .... 75, 96 Moenave Formation -... 75, 76, 77, 96, 102, 109 Moffat County, Colo _._........ 73, 93

Monks Hollow, Utah _..._..... 74, 93, 94, 113 Montana $\ldots \ldots \ldots \ldots \ldots . . .27,28,29,30,67,68,69,78$, $80,81,82,84,85,87,107,108,109$,

$111,113,114$

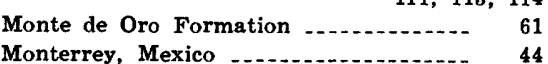
Monterrey, Mexico -.................. $\quad 44$ Moonshine Conglomerate ....... 54, 57,60, 107 Morgan Creek, Oreg ................ 65 Mormon Sandstone .............. 54, 57, 107 Morrisiceras morrisi zone ..............- 22 Morrison Formation -..... 18, 67, 68, 69, 70-75, $77,82,87,88,90,92,93,95,96$, $98,99,108,113,114$

Mount Baker, Wash .............. 66 Mount Carmel, Mount Carmel Junction, Utah

Mount Jura, Calif -................ 57,60 Muddy Creek, Wyo Murderers Creek Graywacke -........... 55

Myophorella -................... 84 montanaensis -........... 87, 113 Mysterious Creek Formation (Canada) - 58

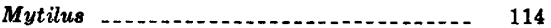

\section{$\mathbf{N}$}

Naknek Formation .................... 59 Navajo Indian Reservation, Ariz _..... 97 Navajo Sandstone .............. 53, 74-77, $95,96,97,98,99,102,109$

Nebrodites 31 Necaxa, Puebla - . Nelchina, Alaska _.................. 59 Neocomian Age -.............. 51, 67, 106 Neocosmoceras _.................. 63 Nephi, Utah Nerinea .......................... 57

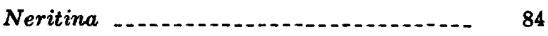
Nesson Formation ........... 67, 69, 82, 109

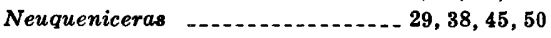
neogaeum

Nevada ... 19, 20, 21, 52, 53, 54, 97, 106, 108, 109
Nevadan orogeny -.

New Mexico _...................... 17

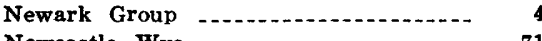

Newcastle, Wyo

Nicely Formation

Nodicoeloceras -................ 20, 21, 22, 55

Nododelphinula _.................. 84

Nooksack Formation -................ 56, 66

Normannites _-.- 22, 23, 37, 45, 55, 56, 57, 58, 80 crickmayi _.................. 22, 23 undulatum - 22

Norphlet Formation - 44, 46, 47, 48, 102, 104, 105 North Dakota - North Ridge Agglomerate ............... 54,60 North Temperate Realm of Kauffman -. 31 Nova Scot:a shelf - 4, 103 Nuevo Leon, Mexico ............ 35, 36, 44, 48 Nugget Sandstone _..... 70, 72, 74, 83, 90, 109 Nutzotin Mountains, Alaska .......... 59

\section{$\mathbf{0}$}

Oakley, Utah -............. 72, 91 Oaxaca, Mexico _............ 23, 25, 45, 49, 51 ,

Ochetoceras $52,102,108,104$ canaliculatum -................ 34,45

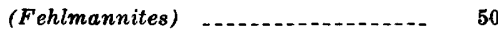
Octocythere

Okanogan County, Wash

Olcostephanus

Olvido Formation (Mexico) $44,48,102,105$

Opis (Trigonopis) -...... 84

Oppelia aspidoides zone (Lyroxyites) Oregon $\ldots \ldots \ldots-17,19,20,21,22,23,24,25,26$, $30,36,37,38,53,55,56,61,63$, 106,107

Orogenic activity ................ 102, 106, 108 Orthosphinctes ............. 24 Ostrea _............. 44, 87, 94, 113, 114 strigilecula

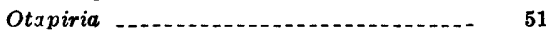
tailleuri Otoites sauzei zone ............. 22, 25, 57, 102 Otter Point Formation -....... 55, 62, 6s, 108 Oxfordian Stage, Alaska -....... 17, 30, 31, 67 ammonite and buchia succession in - 30,38 Atlantic Coast region -........... 103 Cal:fornia $38,53,60,61,62,106,107$ Canada .................. 17, 18, 30, 67 Colorado -................... 95, 113, 114 Cuba ........................ 30, 39, 42 Gulf of Mexico region ............ 17, 30 , $38,47,48,102,104,105$ Idaho _........... 17, 30, 66, 90, 107, 113 Mexico _...... 30, 49, 50, 51, 52, 102, 103 . $104,105,106$

Montana _........... 17, 18, 30, 67, 82, 113 North Dakota Oregon $\ldots \ldots \ldots \ldots 17,30,38,62,66,106,107$ South Dakota ................. 87, 113 Utah ............ 95, 113, 114 Washington _.................. 107 western interior region ............ 18, 30 , $67,102,108,113$ Wyoming _........ 18, 87, 88, 90, 113, 114 Oxynoticeras $\ldots \ldots \ldots \ldots \ldots \ldots \ldots . . .20,45,55,65$ oxynotum [..................... 21 zone $\ldots . . \ldots \ldots$

Oxytoma wyomingensis
$\mathbf{P}$

Page

Pacific Coast region, ammonite succession in -............. 29, 37 characteristic fossils of ..... 55, 56, 58, 59 geologic history of .............. 106 lithologic and stratigraphic features compared in ............ 5 locality bibliographic references for - $\quad 3$ paleob:ogeographic setting of ...... 17 unconformities in -............. 102

Pacific Ocean ....................... 17, 23

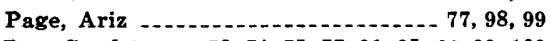
Page Sandstone - 72, 74, 75, 77, 91, 95, 98, 99, 109 Paleobiogeography, setting of ....... 4 Palisade disturbance -................ 4, 102 Palo Blanco Formation (Mexico) -... 49, 50 Paltarpites _.............. 20, 21, 55, 58, 59, 65 Panuco-Elbano area, Veracruz ......... 36 Papilliceras stantoni -..-.-.-.-.-.- 22, 55 (Papilliceras) Sonninia -.............- 57

Parabigotites -._............ 23, 37, 55, 56 crassicostatus -..._-_._-_... 22, 23, 59

Paracadoceras ........................ 29, 58

(Paracadoceras), Cadoceras --.--.-- 23 tonniense, Cadoceras _............ 28

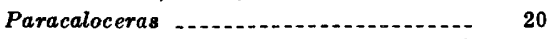

Paracephalites _.................. 27, 28, 37, 81 glabrescens -................... 22 sawtoothensis - .......... 22, 69, 71, 73, 75

Parxchondroceras _.. 37, 69, 71, 73, 75, 80, 81, 89 andrewsi -. 22

Paracoroniceras .................... 21, 58

Parapallasiceras -.................... 33, 40

Parapecten acutiplicatus ..............- 57 praecursor - -

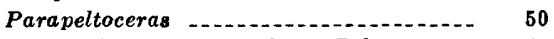

(Parapeltoceras) annulare, Peltoceras - 50

Parareineckeia -........ 22, 26, 28, 29, 37, 38, 55 Parastreblites mazapilensis ............ 32

Parastrenoceras -................. 37, 45 mixteca -....................... 22, 23

Paraulacosphinctes transitorius _........ 26 Paria River, Utah ................. 98

Park Range, Colo ................... 93

Parkinsonia parkinsoni zone -........... 22

Parodontoceras ................ 24, 34, 35, 55 butti callistoides ..................... 36 Paskenta, Calif -........................ 66, 107

Paveloff Siltstone Member, Chinitna For-

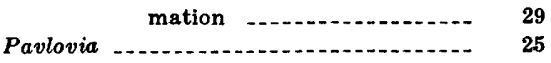
pallasioides zone _........... 24, 26, 31, 32 pavlovi 27 rotunda zone -.............. 24, 26, 31

Pavloviceras _............. 24, 69, 71, 73, 75

(Pavloviceras), Quenstedtoceras .... 30, 38, 82

Pectinatites -.......................... 25 pectinatus zone ............... 24, 26, 31 (Virgatosphinctoides) elegans zone - 30

Peltoceras _..................... 29, 38, 45, 67 athleta zone -................ 22, 47 (Metapeltoceras) _................. 22, 55 (Parapeltoceras) annulare ......... 50

Peñon Blanco Volcanics .............. 60 Pentacrinus - ............................... 86

Peoa, Utah Perisphinetcs burckhardti $-\ldots$ cautianigrae zone -............... 24 danubiensis -......... 33 plicatilis zone -............... 24, 30, 113 transitorius -...................... 33 (Dichotomosphinctes) $\quad \ldots . . .-30,38,39,62$ (Discosphinctes) -................ 30, 38 Peronoceras Phricodoceras -............. 20 
$\begin{array}{r}\text { Page } \\ \text { bakeri }\end{array}$
$\begin{array}{r}\text { Phylseogrammoceras } \\ \text { Phymatoceras }\end{array}$
$\begin{gathered}\text { Physodoceras } \\ \text { Picard Shale Member, Nesson Forma- }\end{gathered}$
tion
$\begin{gathered}\text { Pictonia baylei zone } \\ \text { Pimienta Formation (Mexico) 34, 35, 45, } 49,106\end{gathered}$
$\begin{gathered}\text { Pimienta Member, Jagua Formation } \\ \text { (Cuba) }\end{gathered}$

Pinar del Rio Province, Cuba

Pine Butte Member, Sundance Formation $71,73,85,86,88,92,93,95,113$

Pine Creek, Utah

Pintura, Utah

Piper, Mont ..... 69

Piper Formation . . . $70,78,79,81,83,84,87,88,109$

Pit River, Calif _............ 54, 61

Pittsburg Landing, Oreg _......... 56,66 Placer de Guadalupe,Chihuahua _ $\ldots 32,35,45,51$ Platypleuroceras ................. 21 Pleuroceras .................. 20, 21, 58, 59 spinatum zone ................. 20 Pleuromya _. Plicatostylus _...

Pliensbachian Stage, Alaska ......... $\quad 20$ ammonite and buchias succession in 19 Arizona ........... 97 Atlantic Coast

California _........... 20, 57 Canada $\ldots \ldots \ldots 18,21,65,67,108$ Gulf of Mexico region _....... 102, 103 Mexico _.............. 17, 20, 49, 99, 103 Nevada _... Oregon Pacific Coast region ............... 102 Utah Plomosas, Chihuahua Poe Evaporite Member, Nesson Formation - .

Point Barrow, Alaska Poker Chip Shale, Fernie Group (Canada) -............. 68

Polyplectus _......... 20, 22, 55 Porcupine Dome, Mont Porcupine River, Alaska _.......... 19 Posidonia -...-... 105 Potem Formation Powder River Basin ................ 86 Poza Rica, Veracruz .............. 49, 51 Praestrigites Preuss Sandstone _............. 70, 72, 74, $88,89,90,91,92,93,94,111,113$

Prionodoceras ....................... 31 (Prionodoceras), Amoeboceras _...... 25, 59 spiniferum, Amoeboceras _........ 25

Procerites _.......... 29

Procerithium -...... 84

Prodactylioceras $\ldots \ldots \ldots \ldots, 56,56,65$ davoei _.......... 21 davoei zone -........ 20

Proniceras _..... 24, 27, 32, 34, 35, 45, 55, 63

(Proscaphites), Taramelliceras _...... 30

Prososphinctes _...... 30, 38

Protacanthodiscus

Protancyloceras ............ 24, 33, $\$ 4,36,40$ alamense _... anahuacense barrancense ........ 36 catalinense . hondense ..... 34,36 ramirense Protogrammoceras _............... 20, 56, 65 Provo, Utah _... Pryor Mountains, Mont _.. 78, 81, 82, 83, 84, 85 Pseudoamaltheus
Pseudocadoceras _...... 23, 29, 38, 58, 60,66 grewingki _................ 22, 55, 60 Pseudolioceras compactile _.................... 21, 22 maclintocki ................... 23, 24 whiteavesi _..................... 23

Pseudolissoceras $\quad \ldots \ldots .24,27,32,33,34,36,40$ bavaricum 26 subrasile $\ldots \ldots \ldots, 32,33$ zitteli $\ldots \ldots \ldots \ldots, 24,27,35$

Pseudotoites ............. 23, 37

Pseudovirgatites scruposus _..._..... 26

Psiloceras _.............. 10, 19, 20, 21, 55, 59 canadense _............... 20, 21, 58 erugatas _... 21, 58 planorbis zone .................... 20 (Franziceras) _.............. 19 Puale Bay, Alaska .............. 19 Puebla, Mexico Punta Alegre Formation (Cuba) -.... 42

Purbeck Beds (England) ....... 90

\section{Q}

Queen Charlotte Islands, Canada ... 21, 58, 66 Quenstedtia ......... 84

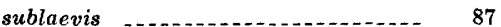

Quenstedtoceras ..... 90 collieri _... henrici … lamberti zone .............. 22, 47, 50 mariae zone ............... 24, 30 (Lamberticeras) collieri _...... 29, 82 (Pavloviceras) _............... 30, 38, 82

\section{$\mathbf{R}$}

Ramona Mesa, Utah, Ariz _... Rancho Cerro Pozo Serna, Sonara -... 31 Rasenia _.................... 24, 25, 30, 45 $\begin{array}{lll}\text { cymodoce zone } & \\ \text { mutabilis zone } & \end{array}$ Recapture Shale Member, Morrison Formation - 75

Red Canyon, Utah Red Creek, Wyo Red Deer Member, Fernie Group (Canada) Red Dome, Mont ....... 78, 84 $\begin{array}{ll}\text { Red Gulch, Wyo } & 84 \\ \text { Red Mountain, Idaho } & \end{array}$ $\begin{array}{ll}\text { Red Mountain, Idaho } & 70 \\ \text { Redding, Calif } & \ldots 1\end{array}$ Redwater Member, Stump Sandstone .- 72, 73, $89,90,92$ Redwater Shale Member, Sundance Formation ......... 70, 71, 73, 82, 85, $86,87,88,89,90,92,93,94,95$ Reineckeia _....... 22, 27, 29, 38, 45, 50 (Kellawaysites) _............ 50 (Reineckeites) _................. 50 $\begin{array}{ll}\text { Reineckeites } & \\ \text { (Reineckeites), Reineckeia } & 22 \\ \text { Ren...... } & 50\end{array}$ (Reineckeites), Reineckeia $\ldots \ldots \ldots \ldots$.
Reynesoceras Rich Member, Twin Creek Limestone - 70, 72, $74,80,81,84,85,88,89,91,92$,
95,98

Richardson Mountains, Canada _. 19, 21, 23, 29 Richfield, Utah ........ 74 Riddle, Oreg Riddle Formation ........... 55, 62, 68, 108 Rierdon Formation ........ 68,69, 81, 87, 89 Rierdon Gulch, Mont _.... 68 Ring Butte, Oreg Ringsteadia _........... 25 pseudocordata zone Rio Blanco County, Colo
Riverside, Wash
Robertson Formation Page Rock Creek Member, Fernie Group (Canada) Rocky Mountains, British Columbia,
Alberta Rogue Formation ........... 55, 61, 62, 107 Romana Mesa, Ariz Root Glacier Formation _.......... $\quad 59$ Rosario Formation (Mexico) _....... 49 Roseburg, Oreg. Roseray Formation (Canada) $\ldots . . .81$
Routt County, Colo Routt County, Colo
Russian platform

\section{$\mathbf{S}$}

Sabinas basin, Mexico _........ 48, 49 Sadlerochit River, Alaska ............ 22 Sailor Canyon, Calif ............... 106 Sailer Canyon Formation Salina, Utah .................... 74, 94, 113 Salina Creek Canyon, Utah _...... 94, 113 Salina Formation (Mexico) -....... 50 Salinites - . Salt _............... 4, 17, 46, 47, 49, 50,67, $99,103,104,105,106,109,111$ Salt domes _... Salt Lake County, Utah _.......... 72 Salt Spring Slate _....... 60 Salt Valley anticline Salt Wash Sandstone Member, Morrison Formation _............. 75, 77 San Andrés Member, Taman Formation (Mexico) - 106 San Cayetano Formation (Cuba) ..... 17, 39 , 44, 102, 103, 104 San Luis Potosí, Mexico ........ 32, 33, 45, 49 San Miguel County, Colo San Pedro del Gallo, Durango _.. 30, 31, 34, 48 San Rafael River, Utah _....... 75, 94, 96 San Rafael Swell, Utah ............ 91, 93, $94,95,96,109,111,113$ San Vicente Member, Guasasa Formation (Cuba) (U)

Sand Creek, Utah Sand Valley, Ariz Sanpete County, Utah Santa Ana Mountains, Calif ....... 29, 52, $53,54,61,106$ Santa Monica Mountains, Calif .... 17, 53, 54 Santa Monica Slate ................ 54,60,61 Sant:ago Formation (Mexico) _....... 45, 48, $49,50,51,104$ Sarasinella _. Saskatchewan $\quad \ldots \ldots 69,78,80,81,82,109,111$ Sawtooth Formation _........... 24,68, 80 Sawtooth Range, Mont _........... 82, 113 Scarburgiceras _............. 24,69, 71, 73, 75 (Scarburgiceras), Cardioceras _....... 25, 30 martini, Cardioceras ......... 24, 25 , $30,55,56,66$

Schlites spinosus Schlotheimia _.... 19, 20, 55 angulata zone Schuler Formation -........ 4, 44, 47, 48, 105

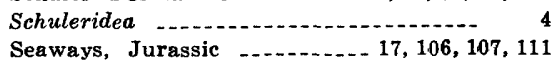
Seaways, Jurassic $\ldots \ldots \ldots \ldots \ldots 17,106,107,111$
Seldovia, Alaska $\ldots \ldots \ldots \ldots \ldots$ Semiformiceras ................... 32 Seneca, Oreg Sevier County, Utah _............ 74 Shaunavon Formation (Canada) _...... 69,80 Sheep Mountain, Wyo _......... 85, 87 Sheridan arch, Wyoming, Montana ... 18, 111 Shoshone River, Wyo _............ 86 Shurtz Creek, Utah Sierra Blanca, Tex ........ 35 Sierra Cruillas, Tamaulipas _........ 34, 35 
Page

Sierra de Catorce, San Luis Potosí _. 32, 33, 45 Sierra de Santa Rosa, Sonora ...... 52 Sierra del Rosario, Cuba _........... 39, 44 Sierra do los órganos, Cuba ........ 39, 44 Sierra Jimulco, Coahuila _........... 36 Sierra Nevada, Calif _........ 17, 29, 52, 53, $54,57,60,61,62,106,107$

Sierra Ramirez, Durango _......... 36 Sigaloceras calloviense -..... 23 calloviense zone .......... 22, 50 Silberlingia _... 61 Silvies Member, Snowshoe Formation -- $\quad 55$ Simoceras _................. 24, 32, 34, 35 (Virgatosimoceras) Sinawaya Member, Temple Cap Sandstone Sinemurian Stage, Alaska ammonites and buchias sucession in 19 Arizona -....... 97 California _... Canada $\ldots \ldots \ldots$. Mexico _...... 17, 19, 49, 52, 99, 102, 103 Nevada _... New Jersey _... Oregon _............ 17, 19,63, 64, 65, 106 Pacific Coast region -... 52 Utah Slick Rock, Colo _... 75, 96 Slick Rock Member, Entrada Sandstone 75, 96 Sliderock Member, Twin Creek Limestone $\ldots 24,70,72,74,80,84,85$, $87,88,89,91,95,99,108,109$ Smackover Formation _... $46,47,48,50,105$

Smith River, Mont Smithers, British Columbia Smithers Formation (Canada) -... 58 Snake River, Oreg., Idaho _......... 17, 56 , $64,66,90,106,107$ Snowshoe Formation _..._. 22, 55, 57, 64, 107 Sohlites _._. spinosus _.......... 95 Sonninia dominans ........... 53 sowerbyi zone ................ 22,57 (Euhoploceras) _..._. 22 (Papilliceras) Sonora, Mexico _............ 17, 31, 38, 51, 52 South Dakota ..... 71, 82, 86, 90, 109, 111, 113 South Fork Mountain Schist Spearfish, S. Dak _.... 86 Spearfish Formation Sphaeroceras _. Spiroceras $69,71,73,75,80,81$ bifurcatum _._._._._._. 22,60 Spiticeras _. 24,39 Springdale Sandstone Member, Moenave Formation

Stanley Mountain, Calif State Bridge, Colo Stemmatoceras _-_ 22, 24, 69, 71, 73, 75, 80, 81 arcicostatum ................... 22 Stenocadoceras (Stenocadoceras), Cadoceras _........ 23, 29 canadense, Cadoceras ............ 23 stenoloboide, Cadoceras _...... 23, 59 striatum, Cadoceras _._._._._. 23, 58 Stephanoceras _..._._. $22,23,24,45,57,80$ humphriesianum zone -..-..-.-22, 23 , $24,57,80,109$

kirschneri Stockade Beaver Shale Member, Sundance Formation $-70,71,85,88,111$ Strenoceras subfurcatum zone -..... 22 Strigoceratidae -...- 22 Stump Sandstone $\ldots \ldots \ldots \ldots, 72,73,82$, $88,89,92,95,108,113$
Suarites bituberculatum _... Pag Subcraspedites plicomphalus _...... Subdichotomoceras _............ 27, 31, 32, 38 nikitini _........................ 32

Subgrossouvia

Sublette County, Wyo _._._. 70

Sublithacoceras penicillatum -...-.- 26

Subplanites _......... 24, 25, 27, 32, 33, 34,45 danubiensis _........ 32 Iclimovi reise (Ilowaiskya) pseudosycthica _..... 27 sokolovi Substeucroceras koeneni Substeueroceras-Proniceras ammonite assemblage -

(Subvertebriceras) canadense, Cardioceras -......... 25 Summerville Formation $93,94,95,96,98,113$

Summit County, Utah Sun River, Mont _........ 68, 80 Sundance Formation ..... 70, 71, 73 $81,82,83,84,85,88,93,111,113$

Sunrise Formation _............. 53, 54 Suplee, Oreg _.... 55, 64, 65, 66, 102, 106, 107 Suplee Formation _............ 55, 64,65 Sutneria platynota Sweet Grass Hills, Mont ... Sweetgrass arch (Montana) _... 80, 81, 82, 113 Swift Formation $69,81,82,90,108,113$ Swift Reservo:x, Mont _._._. Sykes Mountain, Wyo _......... 84 Symon, Durango ................ 32, 33, 36

\section{$\mathbf{T}$}

Takwahoni Formation (Canada) -..- 59 Talkeetna Formation ......... 59 Talkeetna Mountains, Alaska Taman Formation (Mexico) -..- 45, 49, 106 Tamaulipas, Mexico _... 17, 33, 34, 35, 44, 48, 49 Tamn, San Luis Potosí Tampico, Tamaulipas _. 17, 33, 35, 49, 103, 105 Tampico embayment (Mexico) _....... 49,51 Tampico Shale Member, Piper Formation -

Tancredia _........ 95

Tantima, Veracruz

Tantoyuca, Veracruz _............. 36

Taramelliceras (Proscaphites)

Taseko Lake, British Columbia ....... 58

Taylorsville, Calif _..53, 54, 57, 60,61, 106, 107

Telephone Creek, Wyo

Telkwa Formation (Canada) -....... 58

Teloceras _-_... 22, 23, 37, 55, 57, 58, 59, 61 itinsae - . Temple Cap Sandstone $\ldots . . .76,97,98,99,109$ Tenas Creek, British Columbia Tepexic Limestone (Mexico) _._._-_ 45, 50 Tethyan Realm $\ldots \ldots . . . .29,30,37,38,67$ Teton County, Idaho .......... 70 Teton County, Wyo _......... 83, 85, 88 Teton Range, Wyo Texas $\ldots \ldots \ldots 31,45,46,47,48,49,51,103,105$ Thistle, Utah _...... 109 Thompson Limestone _....... 54, 57 Thousands Pockets Tongue, Page Sandstone

Thurmanniceras _..... 36

Tincup Creek, Idaho _............ 90

Titanites -....... 18 giganteus zone ...... 24, 26 cccidentalis
Tithonian Stage, Alaska ammonite and buchia succession in - $\quad 31$ arctic region $\quad 38$ Atlant:c Coast region California $\ldots \ldots .17,36,38,53,57,61,62,63$, 67,108 Canada $\ldots \ldots \ldots, 36,38,67$ Colorado -......... 95 Cuba _.............. 33, 34, 35, 39, 40 definition and correlations of -..-- $s 1$ Gulf of Mexico reg:on _...... 17, 32, 38 Mexico _........... 32, 34, 35, 36, 106, 108 Montana North Dakota Oregon _....... 17, 36, 38, 62, 63, 67, 108 Pacific Coast ragion 108 Russia -...... 34 subdivisions of Texas ... Utah _..... 95

Washington -... 108 western interior region ......... 102, 114

Tmetoceras _............ 22, 23, 56,57,59,65 scissum

Toarcian Stage, Alaska ammonite and buchias succession in 21 Arizona _........ 97 California ........ Canada . . Gulf of Mexico region _........ 102 Mexico Nevada _.

Oregon _............. 17, 21, 64 Utah Tonnie Siltstone Member, Chinitna Formation - 65

Torcer Formation Torquat isphinctes _........... 24, 32, 33, 40

Tragophylloceras _........... 20 ibex zone - 20 Trail Formation Transgressions, marine. See Marine transgressions.

Trinity County, Calif .......... 62 Tropidoceras _. 20, 58 Trowbridge Shale _._. Tulites subcontractus zone -.......... 22 Tulsequah, British Columbia -....... $\quad 59$ Tuxedni Group $\quad 59$ Twelvemile Canyon Member, Arapien Shale -

Twin Creek Limestone _- 24, 70,72, 74, 80, 81, $82,83,84,85,87,88,89,91,94$, $95,96,99,108,109,111$

Twin Creek trough (Wyoming, Idaho, Utah) (........... 18, 111

Twin Peaks, Oreg 65 Twist, Wash _...... 66 Twist Formation Twist Gulch Member, Arapien Shale _. 74, 94 Tylostoma ........ 84

\section{$\mathbf{U}$}

U:nta Mountains, Utah _- 90, 91, 92, 93, 94, 111 Uintah County, Utah _............. 72, 73 Uncompahgre uplift (Colorado) Unconformities, Jurassic _._._._._. 99, 107 United States, southern _... 17, 30, 31, 103, 105 Uptonia $\ldots \ldots, 21,45,55,58,59$ jamesoni ..... 21 zone 20 Uranium Peak, Colo ............... 93 Utah $\ldots \ldots \ldots 72,73,74,75,76,87,89,90,91,99$, $96,109,111,113,114$

$\begin{array}{ll}\text { Utah County, Utah } & 74 \\ \text { Ute Mountains, Colo }\end{array}$ Utica, Mont 68 


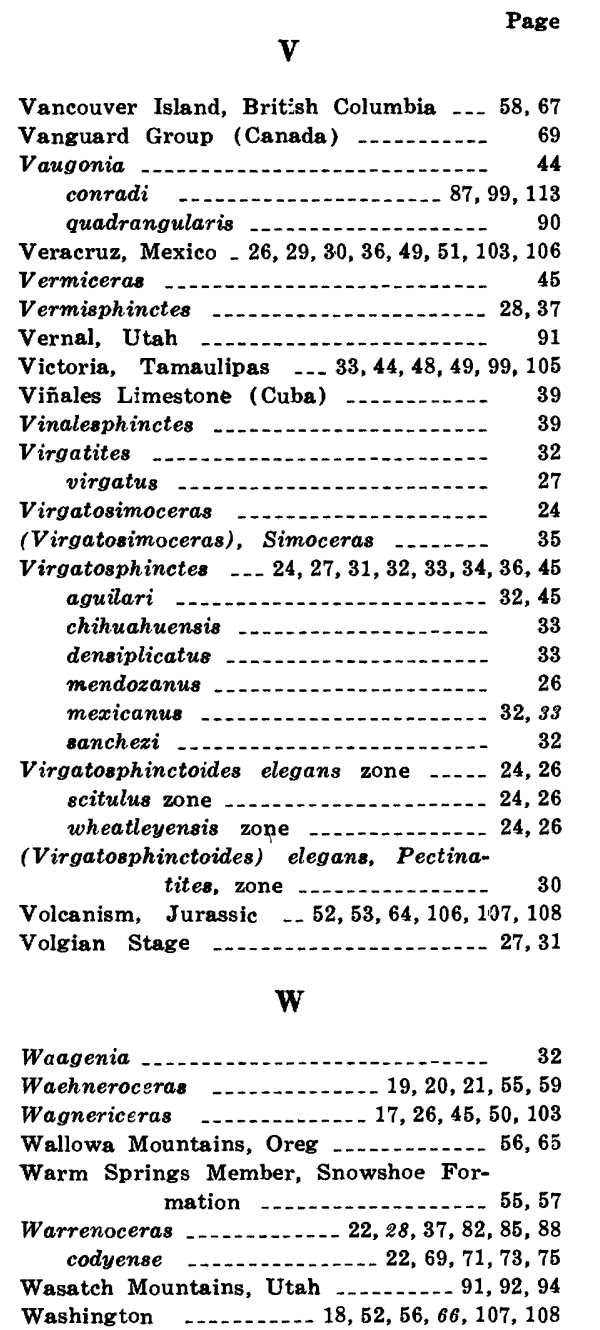

Washington County, Utah $\quad \begin{array}{r}\text { Page } \\ 76\end{array}$

Watrous Formation (Canada)

Watton Canyon Member, Twin Creek Limestone $-70,72,74,87,88,91,96,111$

Webb County, Tex

Weberg Member, Snowshoe Formation - $\quad 55$ Wedge, The, Utah Wells Creek Volcanies Werner Formation .......... 44, 46, 47, 99

Western interior region (United States), ammonite succession and correlation in $\ldots 22,24,27,37,38$ Bajocian Stage in ............... 24 Callovian Stage in ..... 29, 38 characteristic fossils of $\ldots . .69,71,73,75$ geologic history of .......... 106, 107, 108 lithologic and stratigraphic features compared in

locality bibliographic references for

Oxfordian Stage in ................

paleobiogeographic setting of .....

unconformities in 102

Westgate, Nev _........ 21, 106

Westgate Formation

Weston County, Wyo _................ 71

Westwater Canyon Sandstone Member, Morrison Formation -.... 75

Weyla alata White Throne Member, Temple Cap Sandstone

Whitehorse, Yukon Territory -....... 59 Whiterocks River canyon, Utah ... 72, 91, 92 Whitmore Point Sandstone Member, Moenave Formation ...... 96, 97

Wichmanniccras _.... 36

Wide Bay, Alaska _........ 19

Williston basin (Montana, North Dakota) _.... 18,67, 80, 81, 82, 84, $109,111,113$

Willow Creek, Idaho _............. 70

Wind River Basin, Wyo ... 18, 78, 82, 83, 84, 85, $86,87,93,111$
Windhagen

Windhauseniceras interspinosum
Windy Hill Sandstone Member, Sundance

Formation $71,73,85,87,90,92,113$

Wingate Sandstone _.......... 74, 75, 77, 97 Winsor Member, Carmel

Formation -

Winthrop, Wash

Witchellix ........ 56

(Latiwitchellia)

Wolverine Canyon, Idaho -

Wolverine Canyon Limestone Member,

Preuss Sandstone -......- 89, 92

Woodruff, Utah _............ 90

Wrangell Mountains, Alaska _... 19, 28, 59, 67

Wyoming $\ldots . .70,71,78,82,83,90,92,109,111$,

113,114

Wyoming Range, Wyo

90

\section{$\mathbf{X}$}

Xenocephalites $\quad \ldots .-22,28,29,38,45,50,55,82$ vicarius _............ Xochapulco, Puebla ................. 30

\section{$\mathbf{Y}$}

Yakoun Formation (Canada) -....... 58 Yellowstone National Park, Wyo _... 80, 88, 89 Yukon Territory ........... 21, 23, 25, 29, 59

\section{$\mathbf{Z}$}

Zacatecas, Mexico Zaraiskites albani zone ........... 24, 26, 34 zarajskensis _.................. 27 Zemistephanus

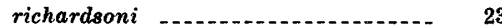

Zigzagiceras _..... floresi zigzag zone ...................... 22

Zion National Park, Utah _........... 97, 98 Zuloaga Limestone (Mexico) _. 44, 45, 48, 49,

6
7
7
6
6
3
0

7
9
9
9

Wind River Mountains, Wyo _..... 70, 86, 88 